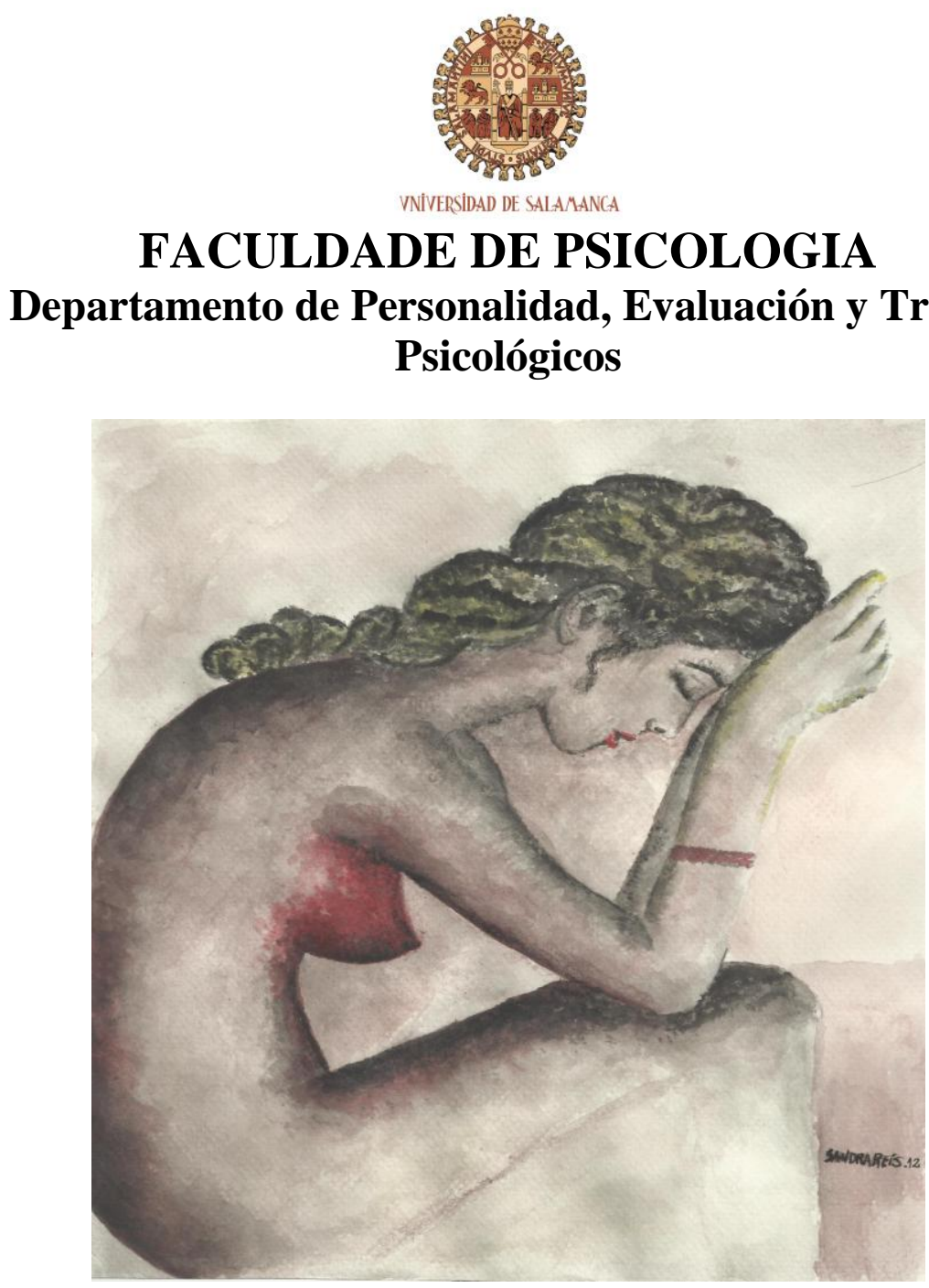

(Imagen cedida per la pintora Sandra Reis)

\title{
Experiencia percibida del sufrimiento y sintomatología psicológica en mujeres con cáncer de mama
}

AUTORA: SÓNIA COSTA

DIRECTOR: FERNANDO JIMÉNEZ GÓMEZ

TUTOR: JOSÉ LUÍS PAIS RIBEIRO (Universidade do Porto. Faculdade de Psicología)

SALAMANCA, Septiembre de 2012 


\title{
FACULDADE DE PSICOLOGIA
}

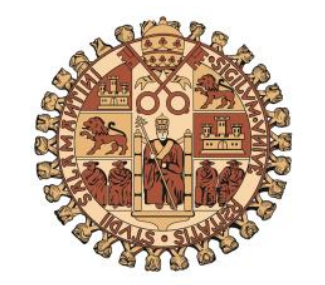

VNIVERSIDAD DE SALAMANCA

\section{DEPARTAMENTO DE PERSONALIDAD, EVALUACIÓN Y TRATAMIENTO PSICOLÓGICOS \\ DOCTORADO EN PSICOLOGÍA CLÍNICA Y DE LA SALUD}

\section{Experiencia percibida del sufrimiento y sintomatología psicológica en mujeres con cáncer de mama}

\author{
ALUMNA: \\ - Sónia Remondes-Costa \\ DIRECTOR: \\ - Fenando Jiménez Gómez \\ TUTOR: \\ - José Luís Pais Ribeiro (Universidade do Porto. Faculdade de Psicología) \\ Tesis presentada como requisito para obtener el Grado de Doctor por la Universidad \\ de Salamanca.
}

SALAMANCA, Septiembre de 2012 


\section{INFORME CONJUNTO DEL DIRECTOR Y TUTOR}

El Trabajo de grado presentado por Dña. SONIA REMONDES COSTA analiza la experiencia del sufrimiento de un grupo de mujeres con cáncer de mama en distintos momentos de su evolución diagnóstica y terapéutica.

La estructura del estudio es totalmente coherente con el tipo de investigación planteado en la que se evidencian dos apartados claramente diferentes: el referente al marco teórico correspondiéndose con el estado actual del tema y el análisis de la investigación existente, y el marco empírico referido especialmente por la metodología, resultados y conclusiones obtenidas.

Por todo ello, su originalidad y aportación a las investigaciones referentes a este tema hace que este trabajo de investigación pueda ser presentado y debatido ante un tribunal que analice los diferentes apartados, planteamientos y resultados obtenidos.

Fdo. Fernando Jiménez Gómez (Director)
Fdo. Jose Luis Pais Ribeiro

(Tutor) 
«Teus Seios...

Teus seios... quando os sinto, quando os beijo na ânsia febril de amante incontentado, são polos recebendo o meu desejo, nos momentos sublimes de pecado...

E às manhãs... quando acaso, entre lençóis das roupagens do leito, saltam nus, lembram, não sei, dois lindos girassóis fugindo à sombra e procurando a luz!...

Florações róseas de uma carne em flor que se ostenta a tremer em dois botões na primavera ardente de um amor que vive para as nossas sensações...

Túmidos... cheios... palpitantes, como dois bagos do teu corpo de sereia tem um rubro botão em cada pomo como duas cerejas sobre a areia...

Quando os tenho nas mãos... Quantas delícias!... Arrepiam-se, trémulos , sensuais, e ao contacto nervoso das carícias tocam-me o peito como dois punhais!...

Meu lúbrico prazer sempre consolo na carne destas ondas revoltadas, que são como taças emborcadas no moreno inebriante do teu colo...»

J. G. de Araújo Jorge, Poemas do Amor Ardente - 1961 


\section{DEDICATÓRIA}

A Meus avós:

Avô Remondes, que partiu antes de ter iniciado este projeto;

Avó Clotilde, que por comigo morar, assistiu ao início desta jornada, e apesar da sua mente já se encontrar em declínio, vivia sempre com inquietação as minhas deslocações a Salamanca;

Avô Américo, o último a deixar-me, aguardou expectante até ao dia sua partida a conclusão do meu doutoramento, e sei que se pudesse, a teria adiado só para assistir, com regozijo, à sua finalização.

Onde quer que estejam, sei que estarão orgulhosos,

Queridos AVÓS, a VÓS dedico este trabalho! 


\section{AGRADECIMENTOS}

Agradeço especialmente:

Ao meu diretor Professor Doutor Fernando Jimenéz Gomez pela sua orientação académica rigorosa, mas principalmente, por ter acreditado neste trabalho, pela confiança, reforço, reconhecimento, amizade e estima constantes ao longo deste trabalho, fazendo dele um verdadeiro companheiro de jornada.

Ao meu coorientador Prof. Doutor José Luís Pais Ribeiro por aceitar supervisionar este trabalho, enriquecendo-o, pois constitui para mim uma referência no âmbito da Psicologia da Saúde em Portugal.

Ao Conselho de Administração do Centro Hospitalar de Trás-os-Montes e Alto Douro, pela autorização da recolha dos dados.

Às mulheres com cancro da mama transmontanas, não só pela sua disponibilização em colaborar no estudo, tornando-o possível, como, e especialmente, pela oportunidade oferecida de aprendizagem a nível profissional, no que respeita ao objeto de investigação, e a nível pessoal, pelos ensinamentos de vida, e nomeadamente, pela força e vontade de viver.

A meus pais, uma vez mais e sempre, pelo amor, apoio, paciência e orgulho.

A Deus, em todos os momentos, mas especialmente nos difíceis, quando a ele recorri, encontrei força para ultrapassar obstáculos, fé para continuar a lutar e não desistir, e tenho a certeza, que em algumas situações, colocou pessoas boas no meu caminho para me ajudar. 
Agradeço ainda:

Ao carismático Professor Ramón Bayés, da Universidade Autónoma de Barcelona, figura incontornável no âmbito da psicologia oncológica internacional, em primeiro lugar pela grandeza da sua obra, que inspirou e enriqueceu este trabalho, e pela nobreza da sua pessoa, que com toda a humildade e disponibilidade me concedeu muitos dos seus artigos. Será sempre uma referência no meu trabalho e na vida.

Ao Prof. Guimarães Lopes, meu professor na universidade, a quem devo o interesse pela temática do sofrimento na doença, numa perspetiva fenomenológica e existencial, pela ajuda bibliográfica fornecida nessa matéria, e pela eterna gratidão de ter impulsionado o início da minha carreira profissional.

Às Dr. As Christiane Northrup (Corpo de mulher, sabedoria de mulher), Rachel Remen (Histórias que Curam), Elizabeth Lesser (Renascer das cinzas: como os tempos difíceis nos ajudam a crescer), Mariela Michelena (À noite sonhei que tinha peito), Rosália Milsztajn (A história dos seios), não sei alguma vez irão ler o presente trabalho, mas cuja leitura dos seus livros me inspirou, fortaleceu, determinou e amadureceu, orientou em momentos de dúvida, e me permitiram compreender, ainda melhor, a natureza do sofrimento humano em geral, e do cancro da mama em particular.

Aos profissionais de saúde, nomeadamente, médicos e enfermeiros do Centro de Oncologia do Centro Hospitalar de Trás-os-Montes e Alto Douro, pela total disponibilidade, companheirismo, e muitas vezes amizade, sentida em alguns dos seus gestos para comigo. Não só pelo empenho com que me ajudaram, mas também, e principalmente, pelo profissionalismo e humanismo com que cuidam dos seus doentes, que em muito me tocou. 
À prima Aida, que no contexto hospitalar me agilizou alguns processos.

Ao colega e amigo Paulo Pimentel, que vim a reencontrar no centro de oncologia, também a sua ajuda foi imprescindível.

Aos administrativos Isabel, Tânia e Emanuel, pelo importante papel desempenhado no acesso às doentes e médicos.

À $\mathrm{D}^{\mathrm{a}}$ Lurdes Amaral, Presidente da Associação Laços para a Vida, pela referenciação de doentes.

Aos colegas do Departamento de Educação e Psicologia da Universidade de Trás-os-Montes e Alto Douro, Prof ${ }^{a}$ Maria da Conceição Azevedo e Prof. Francisco Barros pela ajuda junto do Concelho de Administração e da Direção do Centro de Oncologia; às colegas e Amigas Carla André, Otília Fernandes, Catarina Mota, Magda Rocha e Helena Carvalho, pelo apoio instrumental, mas principalmente, pelo apoio emocional. Ainda uma especial lembrança de agradecimento aos colegas Prof. José Lopes e Prof ${ }^{a}$ Helena Silva pelas palavras de força e incentivo.

Às minhas eternas amigas da jornada profissional (e não só), pela amizade, confiança, crítica e reforço: Berta Nunes, Fernanda Santos, Jacinta Raposo,

Ao meu querido amigo Nelson Rebanda pela disponibilização dos poemas sobre seios que integram este trabalho.

Às Voluntárias do Movimento Vencer e Viver da Liga Portuguesa Contra o Cancro-Núcleo Regional Norte, pelos diferentes contributos dados a este trabalho.

Aos colegas psicólogos da Liga Portuguesa Contra o Cancro - Núcleo Regional Norte, pela disponibilidade demonstrada em determinadas fases do presente trabalho. 
Ao SwáSthya Yôga, descoberta a que a minha alma me conduziu, e muitos benefícios me trouxe para a minha vida, saúde e bem-estar, tão importantes para a prossecução e conclusão deste trabalho.

Por último, não posso deixar de expressar a minha gratidão para com este trabalho. Esta longa e enriquecedora caminhada, na qual os obstáculos e dificuldades, dúvidas e indecisões, desilusões e frustrações, o sofrimento do caminho, muito contribuíram para o meu crescimento pessoal, profissional e espiritual, resultando numa experiência profundamente transformadora.

E por fim, a todos que de alguma forma me ajudaram ao longo desta jornada, mas que por lapso mnésico, não evoquei aqui, perdoem-me, sou-vos igualmente grata.

A Todos,

Sincera e Eternamente, MUITO OBRIGADA! 


\section{INDICE GERAL}

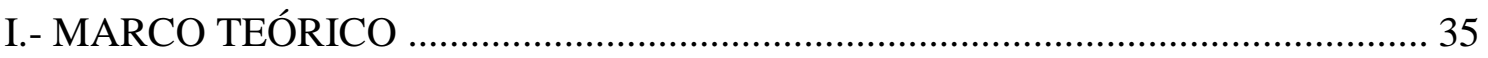

I.1. CANCRO DA MAMA: ASPECTOS FÍCOS DO ADOECER ........................... 36

I.1.1. Cancro da Mama: Dados Epidemiológicos ............................................ 36

I.1.2. Cancro da Mama: Caracterização Clínica ................................................ 41

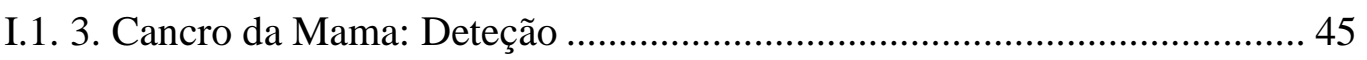

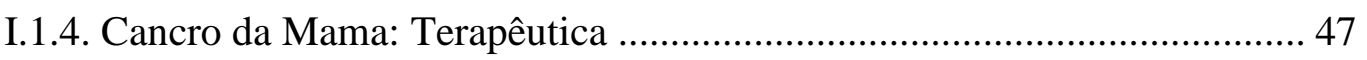

I.1.5. Cancro da Mama: Efeitos Secundários dos Tratamentos .......................... 49

I.1.6. Cancro da Mama: Fatores de Risco........................................................ 51

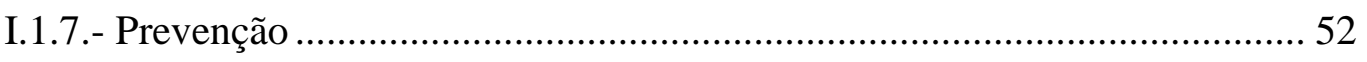

I.2. MAMA: REPRESENTAÇÃO CULTURAL E SEXUAL DO FEMININO ....... 54

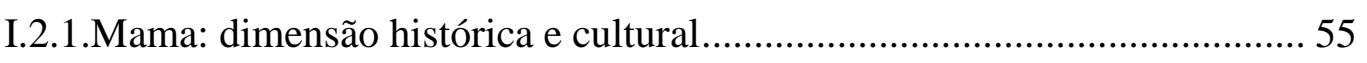

I.2.2. Mama: órgão dos sentidos, afetos e sexualidade..................................... 63

I.3. CANCRO DA MAMA: ASPECTOS PSÍQUICOS DO ADOECER ..................66

I.3.1. Experiência Subjetiva de Sofrimento na Doença no Cancro da Mama..... 67

I.3.1.1. Sofrimento: definição e diferenciação de outros conceitos .................... 67

I.3.1.2. Experiência subjetiva de sofrimento na doença ................................... 74

I.3.2. "Cuidar “e "aliviar” o Sofrimento na Doença .......................................... 85

I.3.2.1. Cuidar e aliviar o sofrimento: tarefa do sistema de saúde e dos

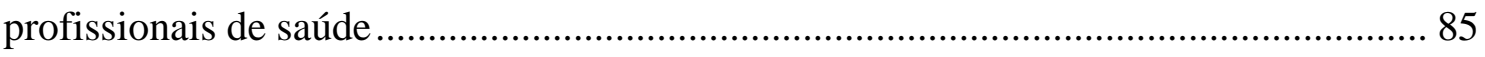

I.3.2.2. Cuidar e aliviar o sofrimento: função da psicologia oncológica ............ 98

I.3.3. A experiência de sofrimento na doença como oportunidade de crescimento 105

I.4. Sintomatologia psicopatológica no cancro da mama ...................................... 111

I.4.1. Personalidade e saúde/doença ........................................................... 113

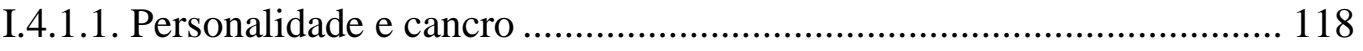

I.4.2. Sintomas Psicopatológicos decorrentes do cancro da mama ................. 129

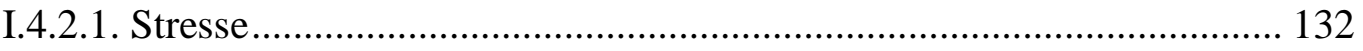

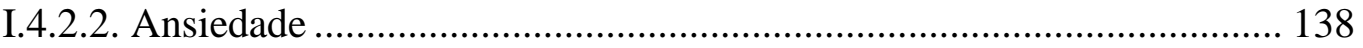

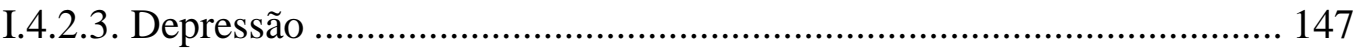

I.4.2.4. Outros Sintomas Psicopatológicos no cancro da mama ....................... 158

I.4.2.6. Terapêuticas Alternativas no alívio do sofrimento e sintomatologia

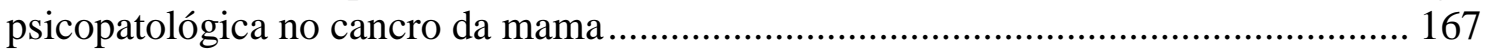

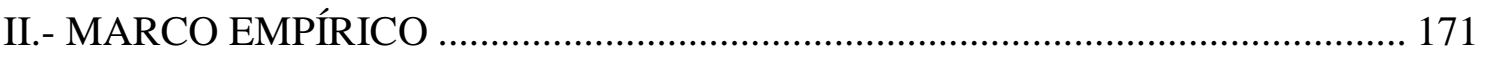

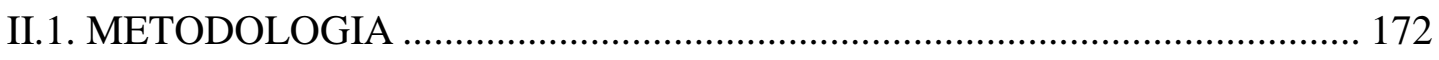


II.1.1. Desenho de Investigação

II.1.2. Definição do Problema e Objetivos ..................................................... 174

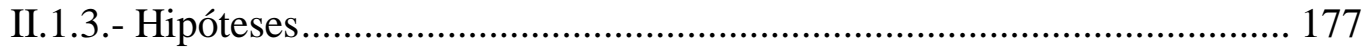

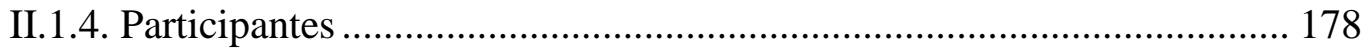

II.1.4.1. Caracterização Sociodemográfica da Amostra .................................. 180

II.1.4.2. Caracterização Clínica da Amostra .................................................... 182

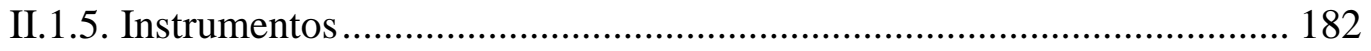

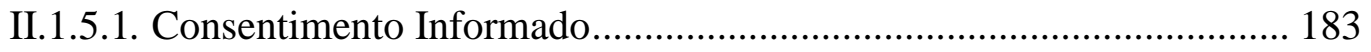

II.1.5.2. Questionário de Dados sócio-demográficos ....................................... 184

II.1.5.3. Questionário História da Doença Oncológica.................................... 184 (IESSD)

II.1.5.4. Inventário de Experiências Subjetivas de Sofrimento na Doença

II.1.5.5. Inventário de Sintomas Psicopatológicos (BSI)................................. 190

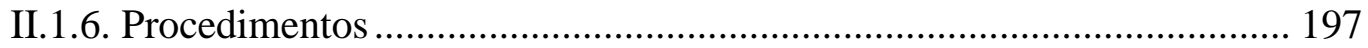

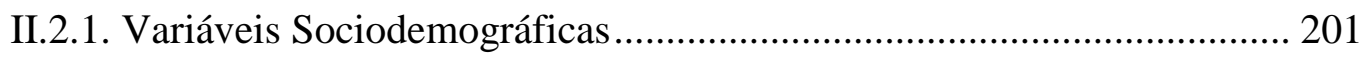

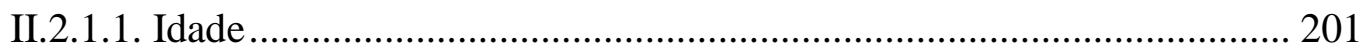

II.2.1.2. Concelho de residência .................................................................. 202

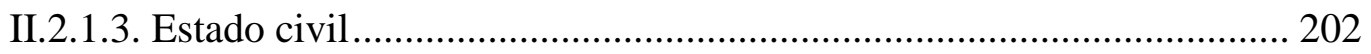

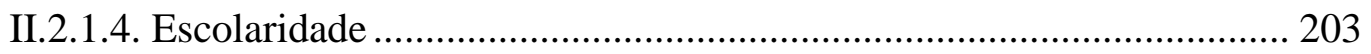

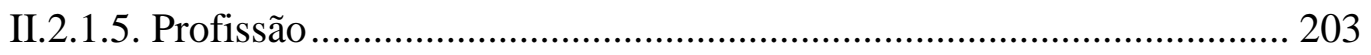

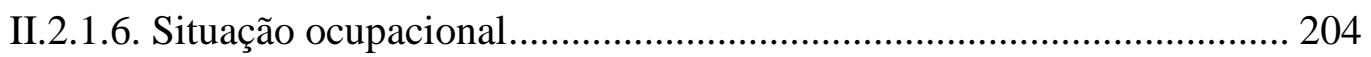

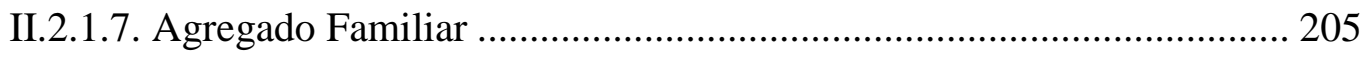

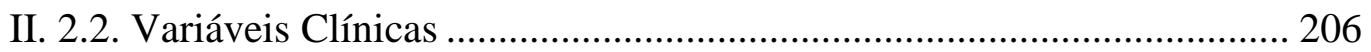

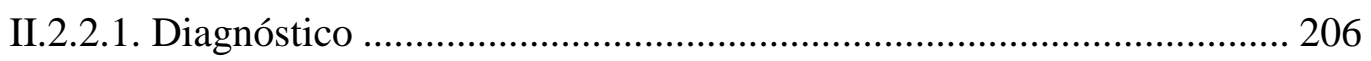

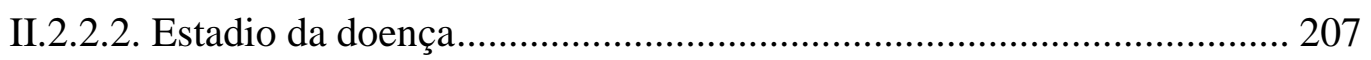

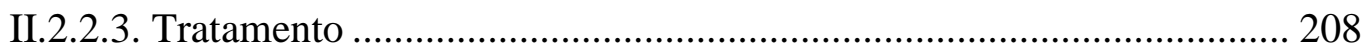

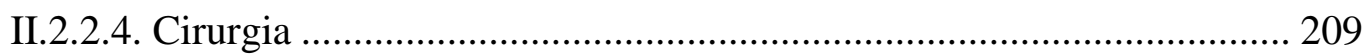

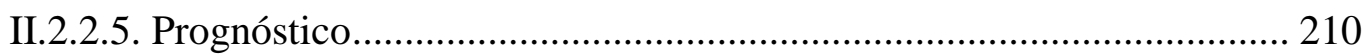

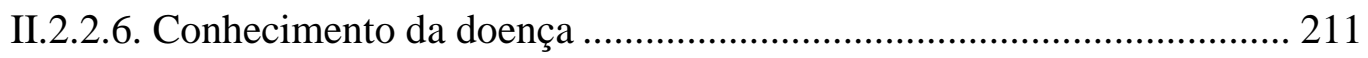

II.2.2.7. Sintomas Físicos ....................................................................... 212

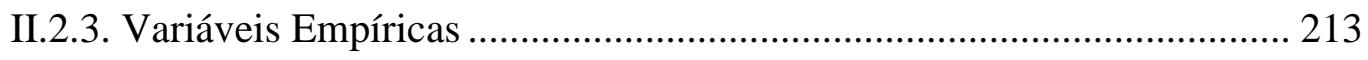

II.2.3.1. Sofrimento - Inventário de Experiência Subjetiva de Sofrimento na

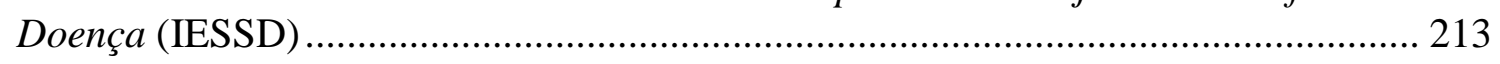

II.2.3.2. Sintomatologia Psicopatológica - Brief Symptoms Inventory (BSI) ... 220

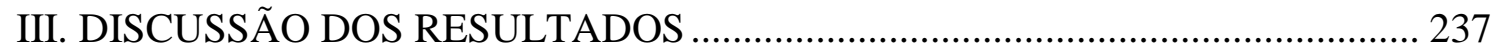

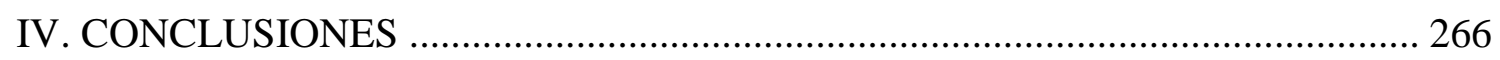


V. REFERÊNCIAS

270

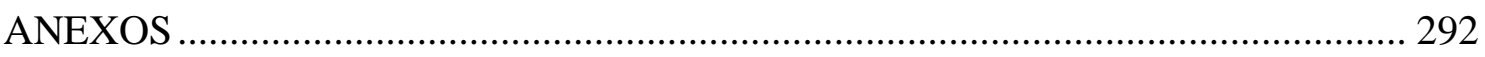




\section{ÍNDICE DE FIGURAS}

Figura 1: Dados Epidemiológicos referentes à incidência e mortalidade do cancro da mama em Portugal........................................................38

Figura 2: Mapa de Portugal e Distrito de Vila Real.............................180

Figura 3: Centro de Oncologia do Centro Hospitalar de Trás-os-Montes e Alto Douro,

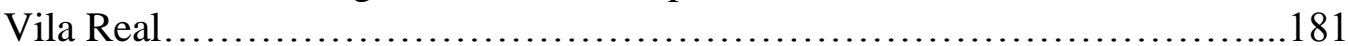




\section{ÍNDICE DE QUADROS}

Quadro 1: Dimensões do questionário da história da doença oncológica..............183

Quadro 2: Dimensões do sofrimento do IESSD e sua distribuição pelas temáticas e

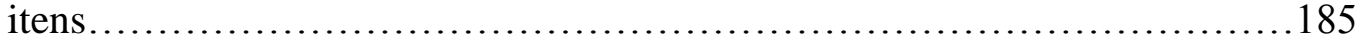

Quadro 3: Descrição das dimensões dos sintomas psicopatológicos do BSI e itens correspondentes................................................... 190 


\section{ÍNDICE DE GRÁFICOS}

Gráfico 1: Distribuição da amostra por grupos de idades. .200

Gráfico 2: Frequências e percentagens relativas ao concelho de residência .201

Gráfico 3: Frequências e percentagens relativas à escolaridade .201

Gráfico 4: Frequências e percentagens relativas à profissão .203

Gráfico 5: Frequências e percentagens relativas à situação ocupacional. .204

Gráfico 6: Frequências e percentagens relativas à composição do agregado familiar 205

Gráfico 7: Frequências e percentagens relativas ao tempo de diagnóstico .206

Gráfico 8: Frequência e percentagens relativas ao estadio do tumor 207

Gráfico 9: Frequências e percentagens relativas ao tratamento realizado .208

Gráfico 10: Frequências e percentagens relativas ao tipo de cirurgia realizada .209

Gráfico 11: Frequências e percentagens relativas ao prognóstico 210

Gráfico 12: Frequências e percentagens relativas ao conhecimento da doença .211 
Gráfico 13: Distribuição dos clusters de severidade pelas dimensões dos sintomas psicopatológicos...

Gráfico 14: Distribuição dos clusters de severidade pelas cinco dimensões do sofrimento. 


\section{ÍNDICE DE TABELAS}

Tabela 1: Estatística da distribuição dos itens e coeficientes de consistência interna de cronbach do IESSD obtidos na amostra em estudo.... 186

Tabela 2: Matriz de correlação bivariada de Pearson entre as dimensões do IESSD obtida na amostra em estudo

Tabela 3: Consistência interna e valores globais das nove escalas do BSI 192

Tabela 4: Matriz de correlação entre as dimensões do BSI 192

Tabela 5: Análise da função descriminante entre indivíduos emocionalmente perturbados e indivíduos da população em geral.

Tabela 6: Estatística de distribuição dos itens e coeficientes de consistência interna de cronbach do BSI.

Tabela 7: Estatística descritiva relativa à avaliação do sofrimento nas doentes com cancro da mama estudadas através do IESSD.

Tabela 8: Diferenças de médias e desvio padrão na comparação entre pares das dimensões do sofrimento.

Tabela 9: Diferenças de médias e desvio padrão das dimensões do sofrimento em função da escolaridade.

Tabela 10: Média e desvio padrão dos sintomas psicopatológicos das doentes com cancro da mama avaliadas. 
Tabela 11: Diferenças de médias e desvio padrão dos pares constituídos para as dimensões dos sintomas psicopatológicos.

Tabela 12: Matriz de correlação bivariada de Pearson entre as dimensões do IESSD e as dimensões do BSI......................................................227

Tabela 13: Análise de regressão múltipla das cinco dimensões do sofrimento em função dos três índices de sintomas psicopatológicos............................229

Tabela 14: Diferenças de médias e desvio padrão dos clusters de severidade .230

Tabela 15: Clusters de severidade relativos às dimensões dos sintomas psicopatológicos.... .231

Tabela 16: Clusters de severidade relativos às dimensões do sofrimento .234 


\section{ÍNDICE DE ANEXOS}

ANEXO 1: Consentimento Informado

ANEXO 2: Questionário de Dados Sociodemográficos

ANEXO 3: Questionário História da Doença Oncológica

ANEXO 4: Inventário de Experiências Subjetivas de Sofrimento na Doença (IESSD)

ANEXO 5: Inventário de Sintomas Psicopatológicos (BSI) 


\section{RESUMO}

Adoecer do cancro da mama é um acontecimento impactante na dimensão psicológica das mulheres por ele atingidas. Apesar de não ser mais associado a "sentença de morte", nem a cura passar obrigatoriamente pela remoção da mama, continua a ser associado na consciência coletiva das doentes a uma experiência de adversidade face aos tratamentos agressivos, mais ou menos prolongados e às respetivas transformações, alterações e perdas que deles decorrem.

A presente investigação teve como principais objetivos estudar a experiência subjetiva de sofrimento na doença e a sintomatologia psicopatológica decorrentes do processo de adoecimento numa amostra de mulheres com cancro da mama. Perceber, enquanto objetivos específicos, quais as dimensões do sofrimento mais afetadas, e qual o contributo das variáveis sociodemográficas e clínicas para a variabilidade da experiência de sofrimento. Identificar a sintomatologia psicopatológica mais prevalente na amostra estudada, a sua variabilidade em função das variáveis clínicas e sociodemográficas. Pesquisar se as variáveis sofrimento e sintomatologia psicológica se relacionam. Investigar se o sofrimento na doença concorre para o agravamento da severidade da sintomatologia psicopatológica. E por último, traçar um perfil psicológico das doentes com cancro da mama estudadas, tendo em conta as variáveis empíricas avaliadas.

Os resultados obtidos indicam que a experiência subjetiva de sofrimento na doença das doentes avaliadas é caracterizada por maior sofrimento sociorelacional e psicológico. Os sintomas psicopatológicos decorrentes da situação de doença mais prevalentes são a ansiedade e a obsessão-compulsão. A escolaridade tem efeitos 
significativos quer na experiência de sofrimento na doença, quer na sintomatologia psicopatológica. Contudo, não foram encontrados efeitos significativos das variáveis clínicas na experiência subjetiva de sofrimento na doença e na sintomatologia psicopatológica. Verificou-se que a experiência de sofrimento na doença e a sintomatologia psicopatológica se relacionam significativamente em todas as dimensões. Não obstante, não ficou demonstrada a hipótese do sofrimento influir no agravamento da sintomatologia psicopatológica. O perfil de morbilidade psicológica das doentes observadas caracteriza-se por maior sofrimento sociorelacional e psicológico e sintomatologia obsessiva-compulsiva e depressiva.

Conclui-se com o presente trabalho que o estudo conjunto da experiência subjetiva de sofrimento na doença e sintomatologia psicopatológica permite conhecer melhor a saúde mental decorrente da experiência de doença das mulheres com cancro da mama, e que os resultados encontrados trazem importantes contribuições para os domínios científico e clínico.

PALAVRAS-CHAVE: cancro da mama, experiência subjetiva de sofrimento na doença, sintomatologia psicopatológica; estudo exploratório 


\section{RESUMEN}

La enfermedad del cáncer de mama es un hecho impactante en la dimensión psicológica de las mujeres que la padecen. A pesar de que ya no está asociada con una «sentencia de muerte», y que su curación tampoco implica ya obligatoriamente la extirpación de la mama, en la conciencia colectiva de las pacientes sigue asociándose a una experiencia de adversidad frente a los tratamientos agresivos, más o menos prolongados, y a las correspondientes transformaciones, cambios y pérdidas que de ellos se derivan.

La presente investigación tuvo como principal objetivo estudiar la experiencia subjetiva de sufrimiento en la enfermedad y la sintomatología psicopatológica derivados del proceso de enfermedad en una muestra de mujeres con cáncer de mama. Asimismo, como objetivos específicos, observar cuáles son las dimensiones del sufrimiento más afetadas, y en qué medida contribuyen las variables sociodemográficas y clínicas a la variabilidad de la experiencia de sufrimiento. También identificar la sintomatología psicopatológica con mayor prevalencia en la muestra estudiada, así como su variabilidad en función de las variables clínicas y sociodemográficas. Indagar si las variables de sufrimiento y sintomatología psicológica están relacionadas. Investigar si el sufrimiento en la enfermedad conlleva el agravamiento de la severidad de la sintomatología psicopatológica. Y, por último, trazar un perfil psicológico de las pacientes con cáncer de mama estudiadas, teniendo en cuenta las variables empíricas evaluadas.

Los resultados obtenidos indican que la experiencia subjetiva de sufrimiento en la enfermedad de las pacientes evaluadas es caracterizada por un mayor sufrimiento sociorrelacional y psicológico. Los síntomas psicopatológicos derivados de la situación 
de enfermedad con mayor prevalencia son la ansiedad y el trastorno obsesivocompulsivo. La escolaridad tiene efectos significativos quiere en la experiencia de sufrimiento en la enfermedad, quiere en la sintomatología psicopatológica. Pero, no fueron encontrados efectos significativos de las variables clínicas en la experiencia subjetiva de sufrimiento en la enfermedad y en la sintomatología psicopatológica. Se comprobó que la experiencia de sufrimiento en la enfermedad y la sintomatología psicopatológica están relacionadas significativamente en todas las dimensiones. No obstante, no quedó demostrada la hipótesis de que el sufrimiento influye en el agravamiento de la sintomatología psicopatológica. El perfil de morbilidad psicológica de las pacientes observadas se caracteriza por un mayor sufrimiento sociorrelacional y psicológico, y una sintomatología obsesiva-compulsiva y depresiva.

Se concluye con el presente trabajo que el estudio conjunto de la experiencia subjetiva de sufrimiento en la enfermedad y sintomatología psicopatológica permite conocer mejor la salud mental derivada de la experiencia de enfermedad de las mujeres con cáncer de mama, y que los resultados obtenidos suponen importantes contribuciones a los ámbitos científico y clínico.

PALABRAS CLAVE: cáncer de mama, experiencia subjetiva de sufrimiento en la enfermedad, sintomatología psicopatológica, estudio exploratorio 


\begin{abstract}
Becoming ill with breast cancer has a significant psychological impact in the lives of women that unfortunately are affected by it. Although currently breast cancer is no longer a "death sentence", nor the treatment has necessarily to go by the experience of the breast ablation, in the patients' collective mind breast cancer is still associated with an adverse experience when facing the aggressive treatments, more or less extend. The comprehension of women's fears implies also the transformations, alterations and losses that the treatment involves.

This investigation had as main goals to study the subjective suffering experience in women with breast cancer. In addition, to investigate the psychopathological symptomatology that steams from the process of falling ill in a sample of women with breast cancer. To understand, specifically, which are the most affected suffering dimensions, and also trying to find which is the contribution of several sociodemographic and clinical variables to the variation of the suffering experience. It was also intended to identify in the sample the most prevalent psychopathological simptomatology and its variability taking into account clinical and sociodemographic variables. Moreover, to investigate if the suffering and the psychological variables are associated, and also to explore if the breast cancer illness' suffering contributes to worsening the severity of the psychopathological symptoms. Finally, it was intended to draw a psychological profile of the breast cancer patients included in the sample, taking into account the assessed empirical variables.
\end{abstract}

The results indicate that in this sample the most severe suffering experience is characterized by great psychological and sociorelacional suffering. The most prevalent 
psychopathological symptoms that stem from the disease are anxiety and obsessioncompulsion. The educational level has a significant effect either in the suffering experience within the illness course, but also in the psychopathological symptoms. On the other hand, no significant effects were found concerning the impact of the clinical variables either in subjective suffering experience, either in the psychopathological simptomatology. There were found significant associations between all the studied suffering dimensions and the psychological simptomathology. Nonetheless, it has not been proved the hypothesis that the suffering experience has an impact in the psychopathological symptoms worsening. The morbid psychological profile of the studied patients' is characterized by a sociorelational, psychological, and obsessivecompulsive simptomathology.

The present investigation results' point out the relevance of a combined study that includes the subjective suffering experience during breast cancer and the psychopathological symptoms variables'. This approach allows researchers to better understand the mental health state of women with breast cancer. In addition, the present study results bring important contributions to the scientific as well as to the clinical domains.

KEY-WORDS: Breast cancer, subjective suffering experience, psychophatological simptomatology, empirical study. 


\section{INTRODUÇÃO}

O cancro da mama continua a ser o segundo tipo de cancro mais prevalente (Crane, 2000; Schottenfeld \& Fraumeni-Jr, 2006), e o mais frequente no sexo feminino (American Cancer Society (ACS) 2009; International Agency for Research on Cancer, (IARC), 2009) em todos os países desenvolvidos. Tendência verificada igualmente em Portugal (Registo Oncológico Nacional, 2008) e a nível regional (Instituto Português de Oncologia do Porto (IPOP) 2008, 2009, 2011).

No entanto, as taxas de mortalidade têm vindo a declinar um pouco por todo o mundo ocidental, e as taxas de incidência a aumentar (ACS, 2009; Crane 2000). Para tal parecem ter contribuído os avanços da medicina em termos de tratamentos oncológicos mais eficazes no combate à doença, melhoria substancial dos meios de diagnóstico e a proliferação de campanhas de prevenção da doença, responsáveis pelo aumento do número de mulheres que realizam anualmente rastreios do cancro da mama. Por outro lado, uma nova tendência parece estar a acontecer de forma transversal a vários países, o aumento do número de casos novos de cancro da mama em mulheres mais jovens, na faixa etária dos 30 aos 45 anos. Esta também é uma realidade a que se tem vindo a verificar desde 2005 na Região Norte de Portugal (IPOP 2008, 2009, 2011).

Apesar de hoje em dia o diagnóstico de cancro da mama deixar de ser encarado como "sentença de morte", e da extração da mama não mais constituir a única garantia da sobrevivência, o seu diagnóstico continua a provocar impacto na realidade intrapsíquica das mulheres por ele atingidas. A consciência da "luta contra a doença" coletivizou-se, no entanto, a representação de uma luta sofrida também. Numa trajetória 
de perdas várias ligadas à dureza e consequências dos tratamentos, às quais se associam o mal estar físico e dor, alterações da imagem corporal (alopécia, magreza ou aumento de peso, retirada da mama), alterações de papéis sociais, das atividades de vida diária e estilos de vida, em suma, comprometimento da qualidade de vida em geral das doentes (Barros, 2008; Dias, Manuel, Xavier \& Costa, 2001; Senderslky, Gus \& Sung, 2002).

Assim, ao longo da jornada processual da doença (diagnóstico, tratamentos, remissão, recidiva, estado terminal), o sofrimento enquanto experiência emocional (Bayés, $1998^{a}$ ), decorrente da perceção de ameaça real ou imaginária de perda da integridade física (Benito, Mati \& Pacual, 2011;Cassel,1991), numa perspetiva existencial, fenomenológica e "despatologizada" (McIntyre, 2004), acompanha a vivência das doentes durante esta disruptiva caminhada.

A doença provoca sofrimento na medida que ao constituir uma ameaça à integridade física, confronta a pessoa doente com a fragilidade da vida e aproxima-a da ideia de morte (Gameiro, 1999), comprometendo a capacidade de perspetivar o futuro (McIntyre, 1995 ). A experiência de sofrimento na doença engloba todas as dimensões da pessoa, física, psicológica, social e existencial (Gameiro, 1999; McIntyre, 1995ª 2004). Encontrando-se o sofrimento físico relacionado com a dor, desconforto, perda funcional e perda de vigor físico; o sofrimento psicológico com as alterações na identidade pessoal, perturbações cognitivas, emocionais e comportamentais; o sofrimento sociorelacional com as alterações afetivo-relacionais e alterações sóciolaborais; e o sofrimento existencial com as atribuições causais face ao aparecimento da doença, questões existenciais e limitações na elaboração de projetos futuros (Gameiro, 1999; McIntyre \& Gameiro, 1999). 
A experiência de sofrimento na doença, nesta perspetiva, pode também oferecer oportunidade de crescimento pessoal. Quando um sentido positivo é atribuído à experiência de sofrimento na doença, mediante a descoberta de um significado existencial para o aparecimento desta no ciclo de vida (Gameiro, 1999; McIntyre, $\left.1995^{b}\right)$.

Todavia, o sofrimento na doença na perspetiva acima descrita é pouco abordado na literatura científica, e pouco atendido nos cuidados de saúde em oncologia. No entanto o sofrimento decorrente do aparecimento da doença é frequentemente verificado em contexto clínico, no acompanhamento psicológico e em terapia com doentes oncológicos. Como tal, o estudo da experiência de sofrimento na doença reveste-se de grande pertinência no contexto dos cuidados de saúde (Bayés, 1998ª , 1998 b, 2000, 2002, $\left.2003^{\mathrm{a}}, 2004,2009,2010\right)$. Na medida que, quando não atendido, interfere com a adaptação ao processo de doença, adesão aos tratamentos, podendo igualmente interferir com a sobrevivência (Bayés, 2004; Gameiro, 1999; McIntyre, 1995ª; McIntyre \& Gameiro, 1999).

O sofrimento associado à doença grave, como explica Gameiro (2000), é uma experiência intensa, que compromete o presente e a capacidade de perspetivar o futuro. Sendo por este motivo condição obrigatória o alívio do sofrimento do doente em psicologia da doença. Por dois principais motivos: por um lado, pela vertente humanitária, enquanto experiência de profundo mal-estar, por outro, pela razão terapêutica, uma vez que diminui a mobilização de recursos psico-afectivos e socias necessários ao ajustamento da doença, interferindo na adesão aos procedimentos médicos. Por esse motivo quisemos estudar a experiência subjetiva de sofrimento na doença em mulheres com cancro da mama, considerando ser esse o contributo científico original do presente trabalho. 
Numa dimensão psicológica diferente, ainda que podendo ser associada à ideia de sofrimento, algumas doentes com cancro da mama podem apresentar sintomatologia psicopatológica despoletada pelo aparecimento da doença, em resultado de dificuldade no ajustamento ao processo da mesma, dos quais os distúrbios de ansiedade (Carvalho, 2008; Derogatis, 1983; Fernandes, 2009; Graner et al., 2008; Hall et al., 1999; Lueboonthavachay, 2007; Montazer et al., 2001; Moreira et al. 2008; Okamuna et al., 2005; Pereira, 2008; Tapadinhas, 2004; Tavares, 1999), stresse (Antoni et al., 2009; Faul et al, 2009; Garafalo et al., 2009; Gouveia \& Tapadinhas, 2008; Holland \& Mostravito, 1980; Ogden, 2004a; Rebelo et al., 2008; Soares \& Alves, 2006) e depressão (Derogatis, 1983; Carvalho, 2008; Fernandes \& McIntyre, 2002; GoldeKreutz \& Anderson, 2004; Gonçalves, 2011; Graner et al., 2008; Greeen et al., 2000; Moreira et al., 2008; Tavares, 1999; Teng et al., 2005, Torres et al., 2010), e os quadros mistos de ansiedade-depressão (Burgess et al, 2004; Eping-Jordan, et al., 1999; Jacobs \& Bovasso, 2000; Maraste et al., 1999; Payne et al., 1999; Patrão \& Leal, 2004) são os mais prevalentes segundo a literatura revisada.

Falamos neste caso, na dimensão psicopatológica do sofrimento na doença. Distinta da descrita anteriormente. Porém, á semelhança da experiência de sofrimento na doença, também a sintomatologia psicopatológica afeta a adesão aos tratamentos, a sobrevivência e compromete a qualidade de vida das doentes com cancro da mama (Carvalho, 2008; Holland, 1998; Li et al., 2012; Mitchell et al., 2012; Pereira, 2008; Teng et al., 2005).

Perceber a relação entre a experiência de sofrimento e a morbilidade psicológica é igualmente uma importante linha de investigação a seguir, também ela ainda pouco explorada (McIntyre, 2004), podendo avizinhar-se como área de investigação promissora, com possíveis mais valias científicas e clínicas e eventuais ganhos em 
saúde e na qualidade de vida dos doentes oncológicos. Acreditamos que neste ponto reside a segunda contribuição original do nosso estudo.

Tendo em conta a nossa sensibilidade para com as problemáticas enumeradas anteriormente, e a pertinência que as mesmas nos parecem merecer no contexto dos cuidados oncológicos prestados às doentes com cancro da mama. $\mathrm{O}$ presente trabalho tem como propósitos gerais contribuir para o estudo do sofrimento com base na experiência subjetiva dos doentes, numa perspetiva "despatologizada" do conceito, tão descurado, segundo McIntyre (2004) pela medicina e pela psicologia; diferenciar o sofrimento existencial do sofrimento psicopatológico; e procurar despertar o interesse da comunidade científica e clínica para o estudo da relação entre as variáveis sofrimento na doença e sintomatologia psicopatológica, e para a relevância destas variáveis nos contextos empírico e clínico em oncologia.

Neste sentido, como objetivos gerais, este trabalho pretende avaliar a experiência subjetiva de sofrimento na doença em doentes com cancro da mama; avaliar a presença de sintomatologia psicopatológica neste grupo de doentes; e traçar um perfil psicológico das doentes com cancro da mama, em termos das duas variáveis empíricas avaliadas. Com base nos objetivos específicos foram elaboradas 8 hipóteses de estudo.

Participaram no estudo 104 mulheres com cancro da mama em diferentes fases do curso da doença (diagnóstico, tratamentos, remissão/sobrevivência, recidiva), com idades compreendidas entre os 29 e os 82 anos de idade, seguidas em consulta em ambulatório e a realizar tratamentos no Centro de Oncologia do Centro Hospitalar de Trás-os-Montes e Alto Douro. Os dados foram recolhidos por hetero-aplicação.

Foi utilizado desenho de investigação de natureza exploratória, descritiva e correlacional, e seguiu-se uma metodologia mista (quantitativa e qualitativa). Pois 
acreditamos que os dados recolhidos qualitativamente, aquando da aplicação dos instrumentos de medida por hetero-aplicação, em ambiente natural onde as doentes são seguidas e tratadas, enriquece a análise dos dados trabalhados quantitativamente. Por outro lado, como defendem muitos autores, a investigação no contexto de doença adquire outros ganhos, quando realizada em contexto hospitalar, diretamente com os doentes e profissionais de saúde, onde todos os procedimentos clínicos podem ser observados e registados pelo investigador (Bayés, 2004) e as narrativas dos doentes registadas e analisadas do ponto de vista do conteúdo (Aureliano, 2007; CarvalhoTeixeira, 2010; Dias, 2005; Pereira, 2008).

As variáveis sociodemográficas e clínicas foram avaliadas através de questionários construídos para o efeito. As variáveis empíricas através de escalas. Para avaliar o sofrimento na doença foi utilizado o Inventário de Experiências Subjetivas de Sofrimento na doença (IESSD) de McIntyre e Gameiro (1999), e os sintomas psicopatológicos foram avaliados através do Brief Symptom Inventory (BSI) de Derogatis (1975), versão de Canavarro (1999) para a população portuguesa.

No presente documento damos a conhecer todas as fases do trabalho desenvolvido. O mesmo encontra-se dividido em duas partes principais, marco teórico e marco empírico.

A primeira parte é constituída pelo referencial teórico que sustenta todo o trabalho de investigação, ou seja, a revisão de literatura referente às variáveis em estudo, com base na qual foi fundamentada a formulação do problema de investigação, formulação de hipóteses, definição de objetivos e seleção dos instrumentos de avaliação a utilizar. 
Este apartado divide-se, por sua vez, em três capítulos. O primeiro denominado “Cancro da mama: aspetos físicos do adoecer", é dedicado a toda a informação relevante acerca do cancro da mama, dados epidemiológicos referentes ao cancro da mama a nível internacional, nacional e regional; caracterização clínica da doença; deteção; terapêutica; efeitos secundários dos tratamentos; fatores de risco e prevenção.

O segundo, intitulado "Mama: representação cultural e sexual do feminino", aborda as representações culturais e sexuais da mama ao longo da história, numa perspetiva histórica e antropológica, no sentido de fornecer uma visão complementar da compreensão das implicações do adoecer da mama na feminilidade da mulher.

O terceiro e último capítulo desta primeira parte é inteiramente dedicado às variáveis empíricas do estudo, e designa-se de "Cancro da mama: aspetos psíquicos do adoecer". Este por sua vez, constitui-se por dois subcapítulos, um dedicado à experiência subjetiva de sofrimento na doença e outro dedicado à sintomatologia psicopatológica.

Neste primeiro, começamos por clarificar o conceito de sofrimento, diferenciando-o de outros que lhe estão associados, frequentemente tratados como sinónimos. Seguidamente definimos experiência subjetiva de sofrimento na doença e explicamos como o sofrimento na doença pode ser cuidado e aliviado pelos profissionais de saúde de saúde em geral e pela psicologia oncológica em particular. Por último, fundamentamos como a experiência de sofrimento na doença pode oferecer uma oportunidade de crescimento. Consideramos que este capítulo é bastante extenso. Apesar do sofrimento, na perspetiva em que pretendemos estudar, ser pouco abordado na literatura científica e pouco atendido na prática clínica, procurámos, desta forma, 
refletir aprofundadamente sobre essa lacuna, no sentido de consciencializar para a continuidade do seu estudo.

O segundo subcapítulo, incide sobre a sintomatologia psicopatológica. Num primeiro momento começamos por explicar a relação entre personalidade saúde/doença e cancro, na medida em que esta desempenha um papel importante no ajustamento à doença e no aparecimento de sintomatologia psicopatológica, e na forma como esta compromete a adesão aos tratamentos, sobrevivência e qualidade de vida. Em seguida, descrevemos os quadros sintomáticos mais prevalentes nos doentes oncológicos em geral, e nas doentes com cancro da mama, em particular. Encerramos o último ponto deste capítulo, propondo um conjunto de intervenções terapêuticas individuais e de grupo no tratamento da sintomatologia psicopatológica decorrente do cancro da mama.

O segundo capítulo alude à parte empírica do trabalho. Nele se encontram sequencialmente descritas todas as fases do processo de pesquisa. Dividindo-se em quatro subcapítulos. O primeiro respeitante à metodologia. Dele fazem parte a definição do problema, objetivos e hipóteses do estudo. Caracterização sociodemográfica e clínica da amostra; descrição dos instrumentos de avaliação e respetivas propriedade psicométricas. O segundo é referente à apresentação dos resultados em função das hipóteses formuladas e dos tratamentos estatísticos efetuados. No terceiro são discutidos os resultados obtidos atendendo à literatura consultada e às hipóteses levantadas. Por último, apresentamos as principais conclusões da investigação realizada. Finalizamos a presente dissertação com a enumeração de todas as referências consultadas. 


\title{
PRIMERA PARTE
}

\author{
I.- MARCO TEÓRICO
}




\section{I.1. CANCRO DA MAMA: ASPECTOS FÍCOS DO ADOECER}

O cancro da mama é atualmente a segunda neoplasia mais prevalente e incidente em todo o mundo, e a mais frequente nas mulheres (Schottenfeld \& Fraumeni-Jr, 2006), por conseguinte, a mais temível entre o sexo feminino. Adoecer de cancro da mama é uma experiência que deverá ser analisada nas dimensões do sofrimento físico, psicológico, existencial e espiritual, social e cultural, não fosse a mama uma herança cultural do feminino. Dar a conhecer e a compreender as várias dimensões deste adoecer é o propósito deste capítulo. O primeiro ponto será dedicado à dimensão física da experiência de doença, onde começaremos por refletir sobre os dados epidemiológicos do cancro da mama a nível mundial e nacional, seguidamente apresentaremos a definição de cancro da mama, sistema de classificação e estádios da doença, bem como, deteção, terapêutica, efeitos colaterais dos tratamentos. Por último, serão analisados os fatores de risco e de prevenção da doença.

\section{I.1.1. Cancro da Mama: Dados Epidemiológicos}

"Uma pessoa pensa logo que vai morrer quando recebe esta notícia!" (40 anos, cirurgia conservadora)

A alta prevalência de cancro é uma preocupação à escala mundial, constituindo a segunda causa de morte nos países desenvolvidos, precedida pelas doenças cardiovasculares (Vasquéz, Rodrígues \& Álvarez, 1998).

O Cancro da mama é mundialmente o segundo mais frequentemente na atualidade e o mais frequente nas mulheres. Por ano registam-se 1.05 milhões de novos 
casos, correspondendo a $22 \%$ dos cancros femininos, e 373.000 mortes. A maioria dos casos verificam-se nos países industrializados, 346.,000 na Europa e 202.000 na América do Norte (Schottenfeld \& Fraumeni-Jr, 2006). Por estas razões, cancro da mama é uma das principais preocupações da saúde pública em todo o mundo (Crane, 2000).

Nos Estados Unidos o cancro da mama é o cancro mais frequente entre o sexo feminino e a segunda causa de morte por cancro nas mulheres. As últimas estimativas da American Cancer Society (ACS, 2009) sugerem que em 2009 nos Estado Unidos apareçam 192.,370 novos casos de cancro da mama invasivo e 40.170 mortes por cancro da mama.

Segundo a IARC(2009) entre 1955 e 2000, a nível mundial, a taxa de mortalidade por cancro da mama foi mais elevada nas faixas etárias maiores que 85 anos, seguida das 75-79 e 80-84.

Na vizinha Espanha, em 2006, o cancro da mama também foi o mais prevalente nas mulheres, apresentando um taxa de mortalidade por cancro de 16\% (IARC, 2009).

O risco de uma mulher ter cancro da mama invasivo em algum momento da sua vida é de cerca de 1 em cada 8 casos, e o risco de morrer com este cancro é de cerca de 1 em 35 (ACS, 2009).

Em Portugal, os dados epidemiológicos são consistentes com os dados universais. Em 2001, segundo o Registo Oncológico Nacional (2008), foram diagnosticados em Portugal 33.052 novos casos de cancro em Portugal. O cancro da mama correspondeu a 30\% desses novos casos, obtendo uma taxa de incidência de 87.8/100.000, sendo o cancro mais frequente nas mulheres portuguesas, representando 1 
em cada 3 novos casos. Registaram-se ainda a nível nacional, 1.600 mortes por cancro da mama.

Em 2002, como podemos observar na figura 1, segundo dados recolhidos no Portal de Oncologia Português (2012), o cancro da mama continua a ser o tipo de cancro mais diagnosticado em casos novos na população feminina, e o que se associa a maior mortalidade por cancro neste grupo.

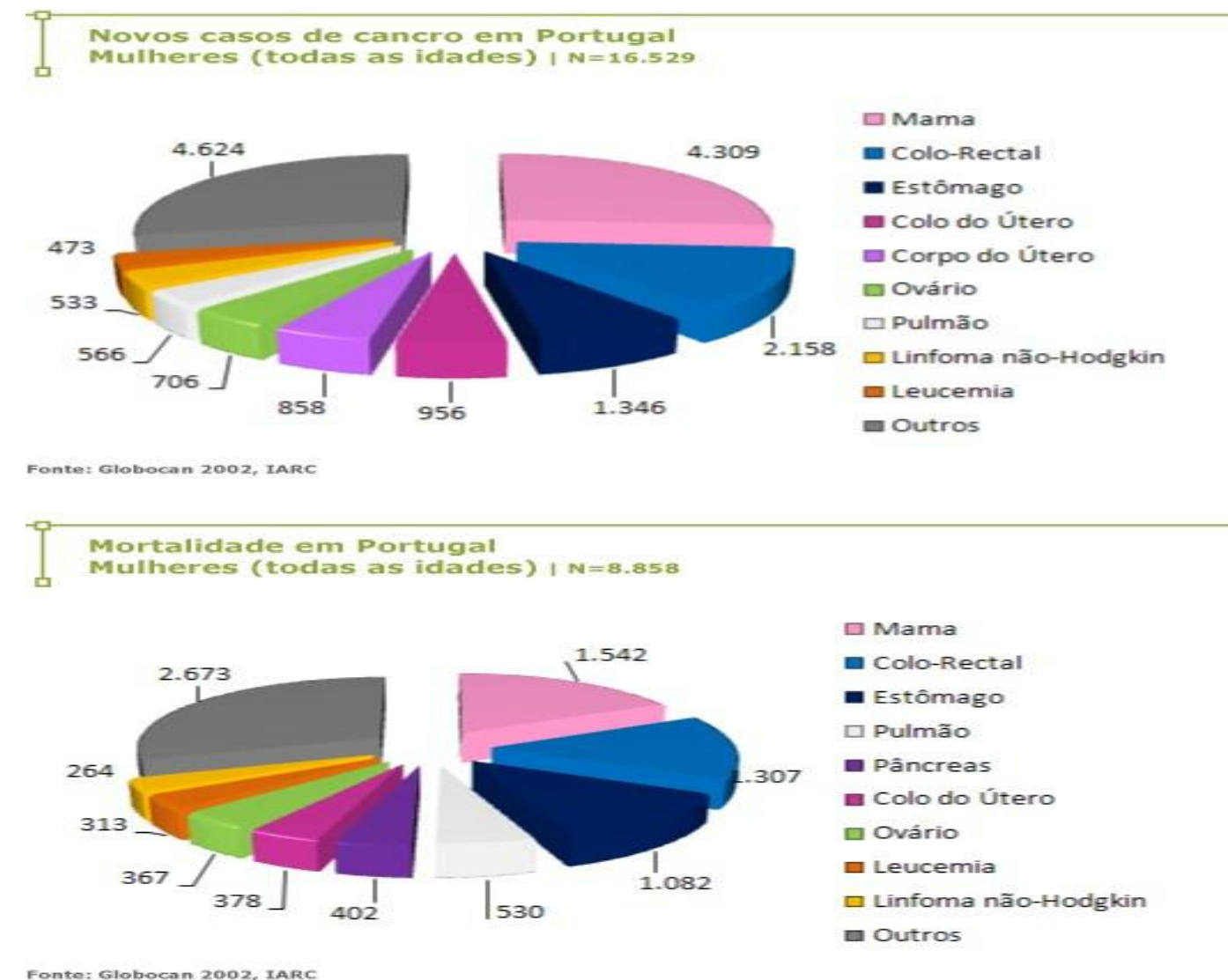

Figura 1: Dados Epidemiológicos referentes à incidência e mortalidade do cancro da mama em Portugal

Fonte: http://www.pop.eu.com/portal/publico-geral/tipos-de-cancro.html

Em 2005, Segundo o Registo Oncológico da Região Norte (IPOP, 2009), dos 12.950 novos casos de tumores malignos, 1.570 foram neoplasias da mama, representando $27.4 \%$ dos cancros, correspondendo a uma taxa de incidência de 92.6/100000. A nível regional norte os novos casos de cancro da mama situam-se nas 
faixas etárias maiores de 75 anos (213 casos), dos 45-49 (209 casos) e dos 55-59 (189 casos). No mesmo ano, foram registadas 336 mortes em mulheres com esta neoplasia.

No ano de 2006, o cancro da mama continua a ser o segundo mais frequente de todos os cancros, mantendo-se o mais prevalente nas mulheres, tendo subido, comparativamente a 2005, para $38 \%$ dos casos de cancro no sexo feminino. Verificouse, relativamente aos dados anteriores, o aumento do cancro da mama nas faixas etárias mais novas, dos 45-49, bem como, nas maiores de 75 anos e no grupo etário das 40-44 (IPOP, 2008).

Ainda em 2007 (IPOP, 2011), a neoplasia da mama, justamente com a colonrectal, próstata e estômago, continuam a representar mais de metade da patologia oncológica da Região Norte, $52 \%$ do total dos casos. Correspondendo a neoplasia da mama a mais de um quarto dos tumores diagnosticados (29\%), registando uma taxa de incidência de 99.9/100.000, mantendo a tendência de subida em relação aos anos transatos. Obtendo uma taxa de incidência de $99.9 \%$, correspondente a 1.700 casos novos, significativamente acima das taxas europeia (85.7\%) e mundial (64.4\%), e a uma taxa de $85.7 \%$ dos tumores malignos na mulher. Ainda no mesmo ano verificaramse nesta região do país 404 mortes (24\%) por cancro da mama, sendo o cancro de maior mortalidade nas mulheres. A estatística epidemiológica demonstrou que as faixas etárias onde se registaram um maior número de casos novos foram: 45-49 (213 casos), 55-59 (207), 50-54 (195) e 40-44(182), mantendo-se o aumento registado no ano de 2006 nas faixas mais novas da idade madura. Do nascimento aos 24 anos de idade foram verificados apenas 16 casos e na faixa etária superior a 85 anos 57.

Em suma, entre 2000 e 2006 (IPOP, 2011) foram diagnosticados 9539 casos de tumores da mama em mulheres da Região Norte de Portugal (97.9\%). A taxa de 
sobrevivência global de 5 anos foi de 83,8\%, ligeiramente acima da média europeia (82.2\%). A maioria das sobreviventes pertence à faixa etária dos 45-54 anos de idade, seguidas das dos 55-64 anos, a sobrevivência é menor nas doentes com mais de 75 anos.

A idade avançada sempre foi associada a um dos fatores de risco não modificáveis do cancro. Também o cancro da mama aparecia com mais frequência em idades avançadas (Crane, 2000). Por sua vez, alguns estudos defendem que a faixa etária dos 40-50 anos de idade apresenta 0.4 vezes maior risco de desenvolver cancro, entre eles cancro da mama, que a do nascimento até aos 39 anos, devido à eficiência reduzida da reparação do ADN verificada neste ciclo da vida (Landis, Murray, Bolden \& Wingo, 1999). Porém, o fato não é corroborado por outros estudos (Rossi, Carrozzino \& Frosina, 1999). Não obstante, é cada vez uma realidade mais realidade premente o aparecimento de cancro, e de cancro da mama concretamente, em idades mais jovens, ou seja, depois dos 30 anos. Outras inversões nas estatísticas epidemiológicas têm sido registadas um pouco por todo o mundo industrializado, das quais Portugal não é exceção, o aumento da incidência do cancro da mama e a descida das taxas de mortalidade por esta doença.

Segundo a ACS (Siegel, Naishadham \& Jemal, 2012), nos Estados Unidos da América entre 1999 e 2008 as taxas de mortalidade por cancro têm vindo a declinar nos quatro principais tipos de cancro (pulmão, colonrectal, mama e próstata), representando o cancro da mama $34 \%$ do declínio geral do cancro nas mulheres. Todavia, a incidência registou um aumento entre 2005 e 2008, constituindo o cancro mais diagnosticado nas mulheres, explicando $29 \%$ dos novos diagnósticos de cancro. O fato parece ser explicado pela eficácia dos tratamentos e o diagnóstico precoce promovido pelas campanhas rastreio associadas a programas de prevenção da doença. (ACS, 2009, Crane, 2000). 
No entanto, apesar do aumento da sobrevivência, para o Ano de 2012, a ACS estima que nos EUA apareçam 226.870 novos casos de cancro da mama (taxa de 29\%), seguindo sendo o mais frequentes nas mulheres, e 39.510 mortes (taxa de 14\%), mantendo-se como a segunda causa de morte por cancro nas mulheres (Siegel, Naishadham \& Jemal, 2012).

\section{I.1.2. Cancro da Mama: Caracterização Clínica} triste".

"Penso que com este problema (doença) não vou durar muito tempo e fico

(42 anos, matectomizada)

O termo Cancro provém do latim "carcinos”, que significa "caranguejo", termo utilizado por Hipócrates para designar os processos neoplásicos, dada a semelhança encontrada entre ramificações da célula cancerígena, que tornam suas presas as células que invade, e as tenazes predadoras do “caranguejo” (Vasquéz, Rodrígues \& Álvarez, 1998).

O crescimento incontrolado de células, denomina-se de neoplasia, que etimologicamente significa "nova formação" (Vasquéz, Rodrígues \& Álvarez, 1998). O processo através do qual as células normais se transformam em células cancerígenas denomina-se carcinogénese (Pfeifer, 2000). As neoplasias podem ser benignas ou malignas. As primeiras caracterizam-se por terem crescimento lento, por não invadirem os tecidos vizinhos e não produzirem metástases. As segundas crescem rapidamente, invadem os tecidos vizinhos e produzem metástases. De uma forma geral, utiliza-se o termo "tumor" como sinónimo de cancro, no entanto, apenas se deveria falar de cancro 
quando se trata de um tumor maligno (Vasquéz, Rodrígues \& Álvarez, 1998). Diz-se "cancro primário" quando o cancro surge pela primeira vez, e "cancro secundário", quando o cancro migrou do seu local de origem e se "metastisou" (Ogden, 2004b).

Segundo a ACS (2009), existem diferentes terminologias relacionados com o cancro. Os carcinomas, termo usado para descrever os cancros que iniciam na camada de revestimento dos órgãos, como a mama. Adenocarcionama, tipo de cancro que inicia no tecido glandular (tecido que produz e segrega uma substância), os lóbulos e o ductos da mama, por exemplo. Carcinoma in situ, termo geralmente utilizado para designar a fase inicial do cancro, ou seja, quando este se encontra confinado ao às células onde se originou. Também são denominados de não invasivos ou pré-cancro. Carcinoma Invasivo (infiltrante), aquele que já cresceu para além das células onde se gerou. E Sarcomas, são cancros que têm origem nos tecidos conjuntivos, como o tecido muscular, adiposo ou vasos sanguíneos. Os sarcomas da mama são raros.

O cancro da mama é um tumor maligno que se desenvolve nas células da mama. É mais frequente na mulher, no entanto, pode também aparecer nos homens. A mama é constituída por gordura, tecido mamário, nervos, veias e artérias. Encontra-se dividida em 20 lóbulos, que se assemelham a cachos de uvas. Poderíamos dizer que as "uvas" correspondem aos "lóbulos" e os "caules" aos "ductos". Os lóbulos produzem leite e os ductos, sendo tubos finos, conduzem o leite dos lóbulos ao mamilo, durante a amamentação (National Comprehensive Cancer Network - NCCN, 2011, Ogden, $\left.2004^{\mathrm{a}}\right)$.

Existem seis tipos de cancro da mama, agrupados em 2 categorias, invasivos e in situ. O carcionama ductal in situ é o tipo mais comum de cancro da mama não invasivo. O tumor está confinado aos tecidos do ducto onde foi gerado. É o tipo de cancro que é 
detetado nos rastreios. O carcinoma lobular in situ, está confinado aos lóbulos, não tendo atravessado as paredes dos mesmos. Não se trata ainda de um verdadeiro cancro, no entanto, a vigilância regular é altamente aconselhada. O Carcinoma ductal invasivo é o cancro da mama mais comum. Tem início no ducto, mas rompe a parede do mesmo e invade o tecido da mama, podendo espalhar-se a outras partes do corpo (metástases). Representa cerca de 8 em cada 10 casos de cancro da mama invasivo. O Carcinoma lobular invasivo, tem início nos lóbulos e pode-se espalhar a outras partes do corpo. Um em cada 10 cancros da mama são deste tipo. O cancro da mama inflamatório, trata-se de um tipo de cancro raro, representando cerca de $1 \%$ a $3 \%$ dos cancros da mama. Caracteriza-se pela ausência de nódulo ou tumor, e por alterações na pele da mama, cor vermelha, grossa, enrugada, fazendo lembrar "pele de laranja", podendo a mama oscilar de tamanho, comparativamente com a outra. A inflamação resulta do bloqueio que as células cancerosas exercem nos canais linfáticos. (ACS, 2009; NCCN, 2011). Por último, a Doença de Paget, também um cancro invasivo raro, que se desenvolve nos ductos lácteos do mamilo. Há duas formas da doença, uma está associada ao cancro invasivo da mama, outra compromete apenas o mamilo. (Ogden, 2004 ${ }^{b}$ ).

À semelhança dos outros tumores malignos, depois de detetado pelos meios de diagnóstico convencionais, o cancro da mama é classificado clinicamente através do Sistema TNM, por forma a avaliar a extensão anatómica do tumor em 3 importantes componentes: $T$ - extensão do tumor primário, podendo o tamanho variar entre T0 não há evidencia do tumor primário, T1, T2, T3, correspondendo respetivamente à variação do tamanho do tumor entre $0,1 \mathrm{~cm}$ e $5 \mathrm{~cm}$, T4 - tumor de qualquer tamanho com extensão até à parede torácica ou pele ("pele de laranja"); $N$ - ausência ou presença e respetiva extensão de metástases em linfonodos regionais, podendo variar entre N0- ausência de metástases nos linfonodos regionais, N1 - metástases em 
linfonodo(s) axilar(es), homolatera(is), móvel(eis), N2 - metástases em linfonodo(s) axilar(es), homolatera(is), fixo(s), N3 - metástases em linfonodo(s) intraclavicular(es) homolateral(ais); $M$ - ausência ou presença de metástases à distância, podendo variar entre Mo - ausência de metástases à distância e M1 - metástases à distância (Crane, 2000; NCCN, 2011; Wittekind, Greene, Hutter, Klimpfinger \& Sobin, 2005).

A classificação das categorias TNM tem como objetivo avaliar a extensão do tumor, permitindo conhecer o seu estádio de evolução, com o objetivo de delinear a terapêutica adequada, bem como, perspetivar o prognóstico. Os estádios de evolução da doença oncológica são seis: estádio 0 - não foi encontrado tumor primário e não há sinais de propagação aos nódulos linfáticos nem a outros tecidos; estádio I - tumor inferior a $2 \mathrm{~cm}$, não se espalhou aos nódulos linfáticos nem a outros tecidos; estádio II A - tumor de 0 a $2 \mathrm{~cm}$, espalhou-se aos nódulos linfáticos ou de 2 a $5 \mathrm{~cm}$, mas não se espalhou; estádio II B - tumor de 2 a 5 cm, espalhou-se aos nódulos linfáticos ou com mais de $5 \mathrm{~cm}$, mas não se espalhou; estádio III A - tumor com menos $5 \mathrm{~cm}$ com nódulos móveis ou fixos; estádio III B - tumor de qualquer tamanho, com invasão da parede do tórax ou pele, espalhou-se aos nódulos linfáticos ou não; estádio IV - o tumor pode ser de qualquer tamanho, o tumor espalhou-se a outros tecidos do corpo. Quanto mais avançado for o estádio da doença, mais comprometido fica o prognóstico (Crane, 2000; ACS, 2009; NCCN, 2011).

O cancro da mama pode ter uma recorrência local e regional, denominado cancro secundário, reaparecendo nos gânglios linfáticos debaixo do braço ou junto à clavícula. Também poderá surgir na outra mama, anos após o primeiro. Ou espalhar-se a outros órgãos, cancro secundário metastático, desenvolvendo metástases à distância. Os órgãos onde se registam mais frequentemente metástases da mama são fígado, pulmões, ossos e cérebro (Ogden, 2004b). 
O estádio da doença aquando do diagnóstico é determinante para o prognóstico (Schottenfeld \& Fraumeni-Jr, 2006). Alguns estudos referem uma taxa de sobrevida de 5 anos em $99 \%$ dos casos, quando o tumor é inferior a $0.5 \mathrm{~cm}$, de $80 \%$ em tumores inferiores a 2 ou $5 \mathrm{~cm}$ e de 50 a $60 \%$ para tumores com mais de $5 \mathrm{~cm}$ (Crane, 2000).

\section{I.1. 3. Cancro da Mama: Deteção}

"Foi-me detetado porque deitava sangue pelo mamilo, eu nem ligava muito, mas diziam-me que não era normal."

(81 anos, mastectomizada)

O sinal de alerta mais frequente é o aparecimento de uma nova massa no seio, um nódulo. No entanto, podem surgir outros sinais: inchaço na totalidade ou em parte da mama; irritação da pele da mama; dor mamária; dor nos mamilos; vermelhidão, descamação ou espessamento da pele da mama ou mamilo; corrimento de leite pelo mamilo fora da amamentação; inchaço ou nódulo debaixo do braço (ACS, 2009).

O nódulo poderá ser descoberto acidentalmente, durante o banho, por exemplo, ou através do auto-exame da mama. O auto-exame é regularmente aconselhado a partir dos 20 anos de idade pelos profissionais de saúde em consulta clínica e aclamado em todas as campanhas de prevenção do cancro da mama. O auto-exame da mama é uma técnica relativamente simples, e consiste na observação e palpação da mama junto ao espelho, a fim de detetar os sinais descritos anteriormente. Para Ogden ( 2004 ${ }^{\mathrm{b}}$ ) e Pennery, Speechley e Rosenfield (2010) é muito importante que as mulheres conheçam bem os seus seios por forma a identificarem qualquer alteração que apareça.

Identificadas a/as alterações, geralmente, as mulheres recorrem a consulta médica a fim de ser feita avaliação clínica. O diagnóstico de cancro da mama pode ser 
feito através de seis exames fundamentais: 1). Exame clínico da mama feito pelo profissional de saúde, baseado na observação e palpação da mama, permite avançar a hipótese de nódulo maligno ou benigno; 2). Mamografia, exame primordial na deteção do cancro em fase incipiente. Trata-se de uma técnica de raios $\mathrm{X}$, que consiste em comprimir a mama entre 2 placas, permitindo identificar um tumor inferior a $1 \mathrm{~cm}$, quando este ainda não pode ser detetado pelo auto-exame e exame clínico; 3). Ecografia, consiste na imagiologia da mama através da utilização de ondas sonoras de alta frequência, é especialmente útil em mulheres mais jovens, cujos seios são mais densos, e na deteção de quistos da mama; 4). Aspiração com agulha fina, tem como objetivo remover material do nódulo, a fim de descobrir se tem líquido ou se é constituído por massa grossa, determinando assim se é cancro ou não; 5). Biopsia com agulha grossa, consiste na remoção de um pequeno tecido do tumor, que será analisado em laboratório, com o intuito de avaliar se contém células cancerosas; 6). Biopsia cirúrgica, é extraída parte ou a totalidade do nódulo ou área suspeita para ser analisada (Crane, 2000; Ogden, 2004; Pennery, Speechley e Rosenfield, 2010).

A realização de rastreios (exame clínico da mama e mamografia), é difundida por todo o mundo como a principal forma de prevenção secundária do cancro da mama, na medida que possibilita a deteção de muito cancros da mama em fase precoce, ainda assintomáticas, permitindo a realização do diagnóstico mais cedo, bem como a intervenção terapêutica, aumentando assim a probabilidade do sucesso terapêutico e por conseguinte, a diminuição das taxas de mortalidade da doença (Crane, 2000). 


\section{I.1.4. Cancro da Mama: Terapêutica}

"Espero que cada vez haja mais meios para tratar os doentes e que não tenham tantos efeitos secundários."

(30 anos, mastectomizada)

A terapêutica a administrar no cancro da mama depende da extensão, localização e estádio do tumor. Poderá optar-se por tratamento local ou por tratamento sistémico. Não obstante, a intervenção terapêutica terá sempre duas vertentes, cirúrgica e/ou farmacológica.

A nível cirúrgico, o tipo de cirurgia adapta-se ao tipo de tumor. Existem diferentes modalidades cirúrgicas. No cancro da mama as cirurgias agrupam-se em duas categorias, cirurgias conservadoras da mama e cirurgias de remoção da mama. As intervenções cirúrgicas de conservação da mama são duas, a Nodulectomia, também conhecida por Tumorectomia, consiste na excisão do tumor e na excisão alargada aos tecidos à volta do tumor; e a Quadranctomia, mais invasiva que a anterior, é responsável por remover um quarto da mama e alguns dos gânglios linfáticos debaixo do braço. Quanto às cirurgias de remoção da mama, conhecidas por mastectomia, temos as mastectomia simples ou total, em que a mama é totalmente removida, podendo conservar os nódulos linfáticos; a mastectomia radical, toda a mama é igualmente removida, bem como, os linfonodos e os músculos acima da mama, desde a clavícula às costelas; e por último, a mastectomia radical modificada, consiste na remoção da totalidade da mama, juntamente com o músculo da parede do peito e alguns dos nódulos 
linfáticos debaixo do braço, é a mais utilizada em casos avançados de cancro (ACS, 2009; Crane, 2000; Ogden, 2004b; Pennery, Speechley e Rosenfield, 2010).

As implicações psicossociais e psicossexuais associadas à mastectomia foram reconhecidas pelos profissionais de saúde e classe científica, proporcionando-se novamente um avanço científico, na reparação do sentimento de mutilação na mulher com cancro da mama. Surge a cirurgia reconstrutiva da mama, que começa cada vez mais hoje a ser uma realidade. Resulta do trabalho de equipa multidisciplinar entre cirurgião, cirurgião plástico, oncologista e radiologista (Crane, 2000; Pennery, Speechley e Rosenfield, 2010).

Ao nível das terapêuticas farmacológicas, aplicam-se as mesmas que nos outros tipos de cancro. Estas podem ser dirigidas ao local do tumor, tratamento local, como é caso da radioterapia. Quando o tumor invade outros tecidos do corpo, será administrada a nível sistémico, tratamento sistémico, como é o caso da quimioterapia, hormonoterapia e imunoterapia (ACS, 2009).

A radioterapia, como o nome indica, é uma terapia por radiação que visa o controlo da doença a nível locorregional. Atualmente é mais utilizada em casos de conservação da mama, com o objetivo de travar a evolução da doença em estádios iniciais (I e II) (Crane, 2000).

A quimioterapia é utilizada no combate às células cancerígenas, que após a cirurgia, ainda possam existir no local do tumor ou que se tenham espalhado através da corrente sanguínea a outras partes do corpo. Geralmente é feita de 3 em 3 semana, em ciclos de 21 ou 28 dias, durante 3 a 6 meses, podendo ir até 1 ano. Algumas sessões duram 10 minutos outras duram 3 a 4 horas (Ogden, 2004 ${ }^{\text {b }}$ Pennery, Speechley e Rosenfield (2010). 
As terapias hormonais são utilizadas, quando se verifica que as células tumorais necessitam de hormonas femininas para o seu crescimento (estrogénio e progesterona), nesse caso, há que privá-las desse alimento. Pode ser utilizada antes ou depois da cirurgia, mas geralmente, é após a cirurgia (Ogden, 2004b; Pennery, Speechley e Rosenfield (2010).

A terapia imunológica, também designada de terapia biológica, consiste na utilização, direta ou indireta, do sistema imunitário da doente para lutar contra a doença e minimizar os efeitos dos tratamentos (Ogden, 2004 $)$.

O avanço da medicina e das suas terapêuticas tem permitido a diminuição das taxas de mortalidade e o aumento da sobreviva em doentes com cancro da mama.

\section{I.1.5. Cancro da Mama: Efeitos Secundários dos Tratamentos}

"Na altura dos tratamentos, o sofrimento foi tanto que pensava - que Deus me leve - foi muito dificil.'

(49 anos, mastectomizada)

Se por um lado, os tratamentos oncológicos têm verificado um desenvolvimento notável ao nível do cura, sobrevivência e longevidade, por outro, apesar dos tratamentos não serem tão agressivos como outrora, ainda continuam a comprometer a qualidade de vida das doentes, despoletando não rara vezes, sentimentos de incerteza e ambivalência relativamente à sua eficácia e continuidade.

Começando pelas implicações da cirurgia no sofrimento físico do adoecer da mama, as consequências são menos dramáticas na cirurgia conservadora da mama que na mastectomia. No caso da primeira, podem verificar-se como efeitos secundários: a perda de sensibilidade no seio; alteração do tamanho e forma do seio e da posição do 
mamilo; dor no seio durante semanas após a cirurgia, em alguns caso, durante anos. A mastectomia, enquanto cirurgia mutiladora, tem efeitos secundários profundos $\mathrm{e}$ dramáticos, a nível físico e psicológico. Alguns efeitos secundários são temporários outros são recorrentes, sendo os mais frequentes: desequilíbrio do peso, em mulheres com o peito grande, originando dores nas costas e pescoço; pele repuxada na área onde o peito foi removido; rigidez nos músculos do braço e do ombro, do lado da mama removida, algumas mulheres perdem irreversivelmente a força nesse membro; formigueiro no peito, debaixo do braço e antebraço; formigueiro e sensação de picada junto à cicatriz; em alguns casos, verificam-se sintomas de "seio fantasma", dor na mama ou prurido no mamilo amputados (Crane, 2000; Ogden, 2004b; Pennery, Speechley e Rosenfield, 2010).

Os efeitos secundários da radioterapia centram-se na zona de radiação, sendo os mais comuns, inchaço e peso no peito, queimaduras locais e alterações da pele na área tratada e cansaço. Estas alterações tendem a desaparecer em 6 a 12 meses. A radiação dos gânglios linfáticos axilares pode provocar inchaço no braço, denominado linfodema (ACS, 2009).

A quimioterapia tem uma componente "citotóxica", que significa «veneno para as células». O objetivo é liquidar as células cancerígenas, no entanto, afeta igualmente as células que se dividem normalmente, razão pela qual desencadeia múltiplos efeitos secundários, a saber: queda de cabelo, inflamação na boca, náuseas e vómitos, diarreia, alteração no ciclo menstrual, cansaço e fadiga, perda de apetite, risco de infeção (devido à diminuição dos glóbulos brancos), facilidade em fazer hematomas ou hemorragias (explicada pela descida das plaquetas no sangue). Estes efeitos desaparecem no fim do tratamento (ACS, 2009, Ogden,2004 ). A comprovar as crenças dos doentes face à quimioterapia, inúmero estudos indicam que $30 \%$ dos pacientes desenvolvem náuseas e 
vómitos antecipatórios, antes ou durante a administração do tratamento (Vásquez, Rodrigues \& Alvaréz, 1998).

As terapias hormonal ou hormonoterapia e terapia imunológica ou imunoterapia têm menos efeitos colaterais. No caso da primeira, os efeitos mais comuns são: cansaço, afrontamentos, corrimento ou secura vaginal, alteração de humor, em alguns casos, aumento de peso. Já a segunda, apresenta ainda menos efeitos graves, em alguns casos podem surgir alguns dos seguintes sintomas: febre, calafrios, fraqueza, náuseas e vómitos, diarreia, dor de cabeça, todos eles de curta duração (ACS, 2009).

Para além dos efeitos secundários a nível físico, acompanhados de sofrimento psicológico, recentemente, têm vindo a ser documentados na literatura efeitos dos tratamentos do cancro da mama no funcionamento cognitivo. Um estudo piloto realizado no Reino Unido verificou afeção da memória verbal em mulheres que fazem terapia hormonal para o cancro da mama (Jenkins et. al., 2002). Um estudo no Canadá, identificou disfunção cognitiva numa minoria de pacientes com cancro da mama (Tannock et.al., 2002). Um terceiro estudo constatou que a quimioterapias adjuvantes e neoadjuvantes têm impacto na deterioração cognitiva, afetando a qualidade de vida destas pacientes (O`Shaughnessy et. al., 2002). Estamos perante resultados que deverão traçar novas linhas de investigação, que estudem o impacto dos tratamentos para o cancro da mama na atividade mental, e suas repercussões na atividade funcional e profissional e qualidade de vida.

\section{I.1.6. Cancro da Mama: Fatores de Risco}

Para a ACS (2009) e segundo a NCCN (2010) os fatores de risco associados ao desenvolvimento de cancro da mama agrupam-se em duas categorias, fatores de risco 
que não podem ser mudados e os fatores de risco relacionados com o estilo de vida. Não dependem da responsabilidade pessoal, o género - pois o cancro da mama é mais frequente nas mulheres; idade - as mulheres mais velhas apresentam maior risco, duas em cada 3 que desenvolvem cancro invasivo têm mais de 55 anos; fatores genéticos $5 \%$ a $10 \%$ dos cancros da mama devem-se a mutações genéticas; história familiar de cancro; tecido da mama denso - devido à existência de mais tecido glandular, aumenta o risco de desenvolver a doença e torna mais difícil a sua deteção; raça - o cancro da mama é mais frequente nas mulheres brancas que nas negras; períodos menstruais ciclo menstrual antes dos 12 anos ou menopausa depois dos 55 anos, pelo maior número de ciclos aumentam o maior risco de desenvolver cancro da mama; história de doença benigna da mama; tratamentos radiológicos na zona da mama em idades jovens, quanto mais jovens (adolescência) maior o risco, diminui a partir dos 40 anos; história de carcinoma lobular in situ - 7 em cada 11 estão em maior risco de ter cancro na outra mama.

Quanto aos fatores de risco associados à responsabilidade pessoal não ter filhos antes dos 30 anos; o uso de pílulas contracetivas - estudos descobriram um risco levemente acrescido comparativamente com as que nunca usaram; terapia hormonal de substituição combinada (estrogénios e progesterona) - aumentam o risco de desenvolver a doença e de morrer com a doença; não ter amamentado durante a gravidez; consumo de álcool; obesidade e não praticar exercício físico (ACS, 2009; NCCN, 2010).

\section{I.1.7.- Prevenção}

A deteção precoce é a variável mais importante no controlo do cancro da mama. A evidencia científica demonstra que a sobrevivência está diretamente correlacionada com o estádio da doença quando é feito o diagnóstico (Crane, 2000). 
A ACS (2009) difunde a necessidade da deteção precoce preconizando a seguinte metodologia em mulheres assintomáticas: 1). Auto-exame mensal a partir dos 20 anos; 2). Exame clínico da mama a cada 3 anos em mulheres do 20 aos 40 anos, e anualmente a partir doa 40; 3). Mamografia a partir dos 40 anos, a cada um ou dois anos entre os 40 e 49 anos, anualmente daqui em diante.

O Auto exame regular, consiste numa prática bastante simples de observação e palpação da mama, muito aconselhado pelas instituições e profissionais de saúde como método de prevenção.

A mamografia é o exame que possibilita a deteção precoce do cancro da mama, ou seja, quando este se encontra assintomático, e como tal, não foi ainda notado no auto-exame nem no exame clínico (Crane, 2000).

Os rastreios têm contribuído para a deteção precoce do cancro da mama, e consequentemente, para o aumento do número de casos novos e diminuição das taxas de mortalidade (ACS, 2009). 


\section{I.2. MAMA: REPRESENTAÇÃO CULTURAL E SEXUAL DO FEMININO}

O seio é o órgão anatómico representativo da sexualidade feminina e da feminilidade. Símbolo por excelência da maternidade e expoente máximo da sexualidade na mulher. Segundo Faria \& Xarepe (2000), “O seio tem um significado social e pessoal particular, que faz com que seja o órgão privilegiado do Ser Mulher. Que órgão se escolhe para simular a maternidade senão o seio que amamenta? Que «semáforo sexual» se utiliza para traduzir a excitabilidade de uma relação sexual senão os seios volumosos? (...) Qualquer ameaça à sua integridade é vivida com sofrimento intenso e profundo, constituindo uma ameaça à mulher, à continuidade do ser, especialmente, do ser feminino (p. 241).

Neste capítulo pretendemos refletir sobre a conceptualização histórica, cultural, religiosa, política e sexual da mama feminina. No sentido de procurar compreender as significações psicológicas, sexuais, sociais e espirituais do adoecer da mama na mulher. 


\section{I.2.1.Mama: dimensão histórica e cultural}

“Seios (...) Esse órgão sempre em evidência, onde o mundo se deita para mamar, sobreviver, se alimentar, cuidar, sonhar e amar. Também é a metáfora da feminilidade que o mundo quer olhar, consumir, triturar e às vezes destruir".

(Rosália Milsztajn, 2010, “A História dos Seios”, p. 57)

"Por não ter peito, sinto-me diminuída enquanto pessoa."

(42 anos, mastectomizada)

“Não abri o meu peito para ninguém ..." (a propósito da procura de apoio emocional após o aparecimento da doença)

(74 anos, mastectomizada)

A mama é um órgão anatómico com múltiplos significados. Os seios são o símbolo da criação, a metáfora do dar e do receber. Nos tempos remotos eram associados à abundância da natureza e da criação (Northrup, 1999). Citando um colega médico, Northrup (1999) refere, "Freud estava completamente errado. Nunca vi uma mulher com inveja do pénis, mas vi certamente uma data de homens com inveja dos seios” (p.289). Por sua vez, Gómez de la Serra (1917, cit. por Yalom, 1998) profere que "quando os poetas falam da morte, chamam-lhe o lugar «onde não há seios»”.

O seio, ou os seios femininos, foram desde o início dos tempos objeto de representação simbólica de natureza diversificada, no consciente e inconsciente coletivo das diferentes épocas. Marilyn Yalom (1998), investigadora e co-fundadora do Institute for Research on Woman and Gender da Universidade de Stanford, no livro História do seio, apresenta-nos uma visão histórica da conceptualização do seio ao longo dos 
tempos, procurando demonstrar como os homens e as instituições tentaram apoderar-se dos seios femininos ao longo da história. A autora começa por explicar que o seio feminino foi desde sempre alvo de conotações "boas" e "más". A figura de Eva constitui disso exemplo entre os Judeus e Cristão, os seus seios "bons" alimentaram os nossos antepassados, já a maçã do pecado é associada aos seus seios redondos. A conotação de "mau" seio resulta desde cedo da conjugação de violência e sexo, e foi sempre tradicionalmente representado na visão masculina.

$\mathrm{Na}$ sua pesquisa histórica e antropológica, a autora explica que o seio possuiu diferentes simbologias, representativas da respetiva mentalidade de cada período histórico, e foi "possuído" de diferentes formas, segundo o poder político e religioso e seus representantes. O seio foi historicamente símbolo do sagrado, erótico, família/lar, política e comercio. Não obstante, apesar das diferentes representações simbólicas, um facto se manteve inalterável até ao final do século XIX, o seio materno determinava a vida ou a morte do recém-nascido (Yalom, 1998).

Yalom (1998) começa por nos falar do seio sagrado, a simbologia primeira do seio, do qual as deusas, sacerdotisas, mulheres bíblicas, santas e virgens são disso exemplo. Quer na tradição judaica como cristã, os seios eram alvo de prestação de culto, por simbolizarem o leite necessário à sobrevivência dos povos. O exemplo do Menino Jesus a beber leite da mãe foi durante alguns tempos metáfora do alimento espiritual das almas cristãs. A Nossa Senhora do Leite é disso personificação. Sua imagem é representada com o seio de fora e o menino ao colo em posição de ser amamentado. Imagem mandada retirar das igrejas no século XV.

Contudo, já antes da era cristã, na pré-história, na era megalítica, paleolítica e antiguidade clássica, o seio foi símbolo da vida, da perpetuação dela, e por isso, 
considerado sagrado. Estatuetas pré-históricas talhadas em osso, pedra e barro de seios fartos e proeminentes, e barriga e nádegas evidenciadas, encontradas desde a Europa Central até à de Leste, parecem assemelhar-se a Deusas da fertilidade, Deusas-mães e Deusas aleitadoras (Yalom, 1998). Símbolos dos poderes femininos da procriação e lactação eram dignos de veneração, pelo carácter de "divindade nutritiva". Em França e na Turquia foram encontrados altares sagrados, que devido à inúmera existência de desenhos e esculturas em forma de seios, se acredita tratar-se de verdadeiros "altares mamários".

Como refere Campbel (1976, cit. por Bancroft, 1991) "A magia criativa do corpo da mulher é prodigioso em si próprio (...). Em todas as suas primitivas epifanias, pois quer nas estatuetas do Paliolítico (antiga idade da pedra), quer no Neolítico (nova idade da pedra), ela é tipicamente a Deusa nua, com um acento iconográfico no símbolo da sua própria forma mágica” (p.41).

O corpo feminino como símbolo da fertilidade foi objeto de atenção, culto divino, forças espirituais e religiosidade, nomeadamente, no início da era agrícola "Mãe terra", a "Grande Deusa da Agricultura", numa época em que a terra era a primeira experiência espiritual da humanidade (Brancroft, 1991). Assente no primado simbólico da fecundidade da terra (mãe - arquétipo do feminino) pelo sol (arquétipo do masculino), pois ele faz as sementes germinar (Brancroft, 1991; Eliade, 1957). A ligação primordial da mulher à terra prendia-se com o facto de ambas serem fonte da criação, mães criadoras. Por essa razão, a partir desta altura se assiste ao enterro dos mortos como forma de regresso ao "seio" da "mãe terra criadora" para repousar em paz. Exemplo disso são os templos fúnebres megalíticos Newgrange e Stonehenge de forma circular, no qual os mortos eram sepultados numa espécie de ventre tumular. Por se encontrarem, segundo algumas pesquisas, alinhados pela lua, e conhecida a ligação 
desta com gestação/germinação, se teoriza a crença deste povos no renascimento. Sendo a estrutura circular relacionada com o ciclo circular da natureza - nascimento, vida, morte, renascimento (Brancopft, 1991). No Norte de Portugal monumentos tumulares contemporâneos do mesmo período (megalítico) denominados "mamoas", pela forma arredondada semelhante a seios femininos (mamas), parecem estar associados à mesma representação simbólica.

A antiguidade clássica é igualmente rica em vestígios relacionados com esta natureza simbólica dos seios. Outro exemplo da veneração do seio, são as famosas estátuas polimasmáticas de Artemisa de Efeso. Estas estátuas dão forma à associação do corpo feminino com a natureza e o alimento. Nas quais os seios (múltiplos) representam os frutos pendentes numa árvore (da vida). Os seios, tal como o ventre, foram venerados em função da sua natureza divina de gerar e manter a vida (Brancopft, 1991).

Simbolismo igualmente sagrado tiveram os órgãos genitais femininos, à semelhança dos seios, pela associação à fertilidade, vida, criação e esperança. Como refere Catherine Blackledge (2006), no livro História da $V$, os genitais femininos são a fonte de toda a vida, a origem simbólica do mundo. A associação dos genitais femininos ao conceito de sagrado e criação é transversal à simbologia multicultural. $\mathrm{O}$ triangulo com um vértice apontado para baixo, ilustrador do útero no seu interior, é o seu símbolo universal. Símbolo da genitalidade feminina desde a pré-história, o triângulo, representado pela quarta letra do alfabeto grego, delta, é a raiz etimológica da palavra útero (delphys). Para Pitágoras e seus seguidores, crentes na conceção do universo segundo leis matemáticas, consideravam o triângulo sagrado, quer pela sua forma perfeita, quer pela simbologia de fertilidade universal, geradora do mundo, da energia em si e de todos os seres. Daí que alguma mitologia clássica proclamasse que "ultrajar, desonrar, maltratar a vagina ou as mulheres á atacar a própria vida. Nada de bom 
pode resultar disso, apenas a destruição da terra e das sua benesses” (pp.54-55). Todavia, tal como os seios, a preocupação em cobrir e esconder os genitais femininos tem início após o advento do cristianismo em todo o mundo ocidental.

Todavia, rapidamente a simbologia sagrada do seio, pela sua condição maternal e vital na sobrevivência humana, passa a assumir o carácter erótico, condenável. E desde então, as comunidades judaico-cristãs passaram a considerar o seio propriedade sua, com ou sem, o consentimento das mulheres. O seio sagrado sucumbe assim ao seio erótico ("globos celestiais"), e toda a sua exibição ou evidência passa a ser proibida pela igreja, passando a ser denominados pelos homens desta de "portas do inferno" e de “chifres projetados para fora" (Yalom, 1998, p.70). Sendo a sua mais pequena evidência de demonstração, moralmente e religiosamente, condenável. Tendo assim, segundo Yalom (1998) início a longa fase do "controlo do seio/dos seios". A feminilidade e os perigos da superioridade a ela associada, são apontados por Bras-Chopard (2007) como a causa da perseguição às bruxas na Idade Média. A autora descreve o fenómeno para além de religioso, como o sendo também político, tendo conduzindo à constituição do Estado Moderno patriarcal, no qual a mulher é colocado "sob tutela" desse mesmo poder.

Yalom (1998) fala-nos seguidamente do seio doméstico, cuja conceptualização tem início na República Holandesa do século XVII, na qual se defendia a amamentação da mãe ao seu filho enquanto responsabilidade civil, pois assim se acreditava contribuir para o bem estar do lar/família e da comunidade. $O$ facto foi documentado recorrentemente na célebre pintura holandesa. Um século mais tarde o fenómeno da amamentação ganha contornos políticos visíveis nos ideias da Revolução Francesa, liberdade, igualdade e fraternidade, sendo a imagem da revolução representada por uma figura feminina com os seios desnudados. Tem início a era do seio político. Assistindo- 
se assim a uma "democratização" dos seios deixando para trás o poder absoluto dos mesmos.

No século XIX, a psicologia e a psicanálise defendem que o seio tem um papel importante na vida emocional da criança. Freud associa o ato de mamar não apenas à função alimentar, mas também à experiência de "bom" ou "mau seio" como determinante para o desenvolvimento da personalidade, e ainda, para o facto do mesmo ato representar o início da sexualidade infantil. Trata-se da era do seio psicológico. $\mathrm{Na}$ viragem do século XIX e início do século XX, com a emergência do capitalismo, assiste-se à era do seio comercializado, o seio visto como objeto de lucro. Para aumentar os seios, são comercializados espartilhos, soutiens, cremes, loções, implantes de silicone. Mais recentemente, a pornografia e o cibersexo, constituem um produto da era seio comercializado.

Historicamente, o seio foi igualmente alvo do interesse da medicina, trata-se da visão do seio médico. Desde a antiguidade, este incide sobre duas visões opostas, o seio como dador de vida e como causa de morte. História mais recente tem o interesse da medicina estética pelo seio. Também esta, associa saúde e beleza, com doença e mutilação. Na medida que veio contribuir para a minimização dos efeitos psicossexuais da mastectomia e melhoria da qualidade de vida das mulheres com cancro da mama.

No penúltimo capítulo da história do seio, Yalom (1998) esboça o retrato do seio libertado. Como temos vindo a verificar, o controlo dos seios das mulheres pelos homens caracteriza grande parte da história do mundo ocidental. Quer esse controlo fosse exercido individualmente, pelos maridos e amantes, quer coletivamente por familiares, igreja, Estado ou medicina. No cerne da questão encontrava-se o ideal que sustentava que a mulher, enquanto ser inferior, era pertença incondicional dos homens. 
Apesar de durante o iluminismo do século XVIII, se terem lançado algumas sementes para os direitos das mulheres, e destas preocupações assumirem maior importância ao longo do século XIX, somente nos anos 60 e 70 do século XX, a reivindicação e proclamação de igualdade direitos entre homens e mulheres se tornou uma realidade. Nesta luta, o seio assumiu uma notável importância simbólica. O soutien enquanto peça de roupa interior acessível a todas as classes sociais, de certa forma, obrigatória para todas as mulheres, é utilizado como objeto chave de protesto. A recusa do uso de soutiens reiterada na manifestação pela libertação das mulheres, em prol da igualdade de género, que se tornou conhecido como o ato solene da "queima dos soutiens", coloca os seios no centro desta reivindicação. Desta forma, uma vez mais o seio faz história, neste caso, e possivelmente pela primeira vez, a história de mulheres, que no ato de retirar o soutien, libertando seus seios de "amarras", com os seus seios soltos, dão voz à sua libertação, na conquista pela mesma igualdade de direitos dos homens, e reapropriam-se dos seu corpo, tornando-se donas dos seus seios. Exemplo disso é também a prática do topless nas praias europeias e americanas (Yalom, 1998).

Por último, a autora defende que na atualidade, assistimos à era do seio em crise. Apesar da perspetiva feminina sobre a simbologia dos seios nunca ter sido documentada historicamente. Hoje, os seios associados à feminilidade, maternidade, alimentação, erotismo, sexualidade, em suma, à vida, face aos números assustadores do cancro da mama, reafirmam o sentido de que pertencem verdadeiramente às mulheres. Os seios, representam na atualidade, na visão da autora, a tensão existencial clássica da antiguidade grega entre Eros e Thanatos. Por um lado simbolizam vida, saúde e beleza, por outro, doença e morte. Por essa razão, algumas mulheres começam a tomar a decisão de retirarem seus seios como forma de prevenção do cancro da mama (Mitsztajn, 2010). 
Apesar de atualmente a posse dos seios pelas mulheres seja um dado adquirido, o cancro da mama, constitui um exemplo paradigmático de como por vezes, em alguns casos, os homens persistem na sua apropriação, quando abandonam as companheiras quando estas devido à doença retiram o seio.

No seu trabalho História do seio, Yalom (1998) demonstra-nos que os seios, apesar de constituírem uma parte do corpo feminino, a história revela que recorrentemente não foram tratados como pertença feminina. E a sua simbologia raramente refletiu os sentimentos das mulheres acerca deles. Esta parte do corpo da mulher objeto de relação amor/ódio, foi usurpada, amordaçada, violada, apropriada, usada e explorada, reiteradamente, pelo sexo masculino. Desde o homem que acaricia seus seios, aos artistas, estilistas, industria têxtil, religiosos, poder político, médicos, cirurgiões plásticos, industria cosmética e industria pornográfica. Apesar de tudo isto, como ficou patente, os seios estiveram sempre no "seio" da história da humanidade. Motivo pelo qual, ainda hoje continua a fazer história nos domínios da medicina estética, da sexualidade, da industria do sexo, e nomeadamente, na medicina, não fosse o cancro da mama, a doença oncológica que mais mulheres aflige e atinge em todo o mundo.

O seio tem representações diferentes aos olhos de quem o vê. Os bebés nele vêm alimento, os homens sexo, os médicos doença, os empresários lucro, as religiões símbolos espirituais ou pecado, os psicanalistas uma porta para o inconsciente, os políticos interesses nacionais. No entanto, esta multiplicidade de olhares dá conta do lugar privilegiado do seio no "alimento" da imaginação humana.

Apesar da sua pertinência, a perspetiva antropológica e sócio-cultural da mama ou seio é pouco estudada em psicologia, quer ao nível das representações simbólicas e 
significado da experiência da doença, e das possíveis perdas que pode acarretar, quando implica a "estripação" do órgão da feminilidade, bem como, ao nível da relação entre o significado e representação simbólica do seio, na forma como as mulheres vivem a sua feminilidade e o aparecimento do cancro da mama. Procurámos neste capítulo despertar para o interesse do seu estudo, quer para a psicologia me geral, quer para a psicologia oncológica, em particular.

\section{I.2.2. Mama: órgão dos sentidos, afetos e sexualidade}

"Fico (...) espantada com a frequência com que as mulheres sentem no seu corpo, especialmente na zona dos seio e do coração, quando estão a dar, a amar e a reagir às necessidades dos outros".

(Joan Shinoda Bolen, A Travessia para Avalon, In. Northrup, 1999.)

“Não abri o meu peito para ninguém ..." (a propósito da procura de apoio emocional após o aprecimento da doença)

(74 anos, mastectomizada)

Os seios enquanto associados à maternidade, sexualidade e sensualidade feminina, são por isso fonte inesgotável de prazer, quer no ato sexual, quer durante a amamentação (Santos, 1999). Milsztajn (2010), explica que as mulheres nascem com seios, porque representam a natureza da mulher, do feminino, nas suas dores e descontentamentos como em seus prazeres. Porque são os órgão que abrigam as glândulas responsáveis pela produção e secreção láctea, têm uma ligação direta com a forma de exercer a maternidade (Bourbeau, 2009).

Clarissa Estés, psicanalista junguiana, no livro "mulheres que correm com lobos: contos e histórias do arquétipo da mulher selvagem” (2004) descreve-nos 
Baubo, uma bailarina mágica sem cabeça, que consolava Deméter (mãe-terra) pela perda de sua filha Perséfone, sendo seus mamilos os olhos e a vulva sua boca. A propósito deste conto da mitologia grega, a autora diz-nos que "ver com os mamilos é sem dúvida uma qualidade sensorial. Os mamilos são órgãos psíquicos, sensíveis à temperatura, ao medo, à raiva ao barulho. Eles são órgãos dos sentidos tanta quanto os olhos da cabeça” (p.423). Portanto, ma visão metafórica cultural, histórica e mitológica dos seios femininos.

Pela sua localização na caixa torácica, junto do coração e dos músculos peitorais, os seios são frequentemente designados de peitos, de colo ou peito feminino. Por essa mesma razão, associa-se desde longa data o peito ao centro que abriga os afetos e as emoções. Quer na forma de sentir, quer na forma de exprimir afetos, de "dar colo". Sendo o "ato de dar colo", uma característica do feminino. O peito é sempre um órgão de relação. A amamentação, para além de fornecer alimento, é um momento especial de relação mãe-filho. Através dela, a mãe fornece ao filho ingredientes essenciais para o seu desenvolvimento, nutrindo-o com alimento e com amor. Por conseguinte, a mama/seio simboliza igualmente a dimensão afetiva feminina.

Bourbeau (2009) associa os seios à formam de agir maternalmente com os outros (filhos, família, cônjuge, com o mundo em geral). A autora explica que os problemas de saúde nos seios se associam a inseguranças vividas relativamente ao alimentar e proteger aqueles que tratamos maternalmente. Segunda a autora, as pessoas que padecem de problemas nos seios vivem preocupadas com aqueles que amam, descorando as suas necessidades, a si mesmas. Tratam-se de pessoas controladoras na forma de cuidar maternalmente, exigindo muito de sis mesmas. 
Também por essa razão, pesquisas desenvolvidas, nomeadamente na América Latina, encontram relação entre a experiência afetiva-emocional das mulheres o desenvolvimento de cancro da mama. Segundo a medicina tradicional chinesa, por se localizar perto do coração, naquela que é o centro energético do quarto chacra (anáhata chacra), onde as emoções são guardadas energeticamente. Emoções como mágoa, desgosto, dificuldade em perdoar a si ou a outros, bloqueiam a energia dos seios, impedindo a criação. Explicando assim, o aparecimento da doença (Northrup, 1999). Voltando ao pensamento de Bourbeau (2009), ter um problema na mama, relaciona-se com a dificuldade ou incapacidade em "alimentar" aqueles que tratamos maternalmente. Simões (2008), acrescenta que qualquer problema da mama se associa a dificuldade na vivência da feminilidade. Ou porque há um investimento exclusivo na maternidade, ou pelo predomínio de uma vida rígida, assente no rigor e no auto-controlo, explica o autor.

Contudo, esta ideia não é nova, já na antiguidade clássica Hipócrates, pai da Medicina, exclamava a ligação entre o emocional e o adoecer físico. Galeno, médico do século II A.C., defendia que mulheres melancólicas tinham maior predisposição para desenvolver tumores nos seios (Vásquez, Rodrígues \& Álvarez, 1998). Fernanda Santos (1999), jornalista brasileira na área da saúde, no livro "Tire essa magoa do peito”, com base no testemunho de doentes com cancro da mama, demonstra como emoções “ruins” (mágoas, ressentimentos, ódio, entre outras), podem explicar o aparecimento da doença. Outros trabalhos indicam que a dificuldade de superação de situações vividas, impregnadas de carga emocional, por crenças disfuncionais e mágoas e ressentimentos ligados a acontecimento relacionais com familiares e conjugues, se associam ao aparecimento do cancro da mama (Neme \& Bredariolli, 2010; Neuber, Neme \& Uemura, 2010). Esta relação entre a personalidade, emoções e acontecimentos significativos e o aparecimento de cancro da mama é bastante pertinente, todavia, os 
estudos não têm sido conclusivos a esse respeito. O tema será novamente abordado no capítulo seguinte.

\section{I.3. CANCRO DA MAMA: ASPECTOS PSÍQUICOS DO ADOECER}

O cancro da mama exerce um importante impacto no estado de saúde e na funcionalidade, bem como, na perceção de Si- própria, auto-estima e saúde mental, comparativamente com outros tipos de cancro (Sendersky, Gaus \& Sung, 2002). O cancro da mama despoleta alterações no funcionamento biopsicossocial, implicando necessidade de reajustamento das vivências intrapsíquicas, uma vez que se trata de uma doença, potencialmente, mortal, por um lado, e profundamente estigmatizante para a doente enquanto mulher, por outro (Dias, Manuel, Xavier \& Costa, 2001). O medo de ficar "incompleta" é o fantasma que assola a feminilidade destas mulheres.

A descoberta que o aparecimento de cancro afeta a dimensão psicológica dos doentes, comprometendo a adesão aos tratamentos oncológicos e a eficácia terapêutica, foi precisamente o que impulsionou o surgimento da psico-oncologia, primeiro em 1961, na Argentina, com José Schavèlson, cirurgião oncologista e mais tarde psicanalista, propondo pela primeira vez o conceito. Sendo em 1989, nos Estados Unidos com Holland, fundado o International Psycho-Oncology Society (IPOS), apresentando uma definição clara e objetiva do conceito. Na Europa, Bayes utilizou o termo psicologia oncológica, para falar da aplicação dos conhecimentos e princípios psicológicos à medicina oncológica (Veit \& Carvalho, 2008). As mulheres com cancro da mama, em determinado grau e em algum momento, apresentam problemas psicossociais (Barros, 2008), de carácter adaptativo ao percurso de doença ou 
psicopatológicos, quando a adaptação não se verifica. Todos os doentes oncológicos vivenciam a doença como um acontecimento adverso e disruptivo, gerador de sofrimento. Não obstante, nem todos apresentam sintomatologia psicopatológica. Ou seja, nem toda a experiência de sofrimento na doença é acompanhada de desordem psicológica. Em alguns casos, cada vez mais frequentes, o processo de doença é vivido como uma trajetória de aprendizagem existencial e espiritual, ainda que sofrida. Contudo, nem sempre é fácil o diagnóstico diferencial. Discernir o sofrimento "normal" face a uma situação exigente, do sofrimento psicopatológico decorrente da incapacidade de ajustamento à situação é impreterível. Não raras vezes, se incorre no erro de "psicopatolizar" o que é "normal" face a uma situação desta natureza, e de “normalizar", numa atitude de desvalorização, o sofrimento pessoal, comparativamente com as "queixas" físicas.

Constitui o objetivo deste capítulo dar a conhecer o impacto do cancro da mama na dimensão psicológica das doentes, na perspetiva existencial da experiência subjetiva de sofrimento na doença, quer na perspetiva do sofrimento psicopatológico.

\section{I.3.1. Experiência Subjetiva de Sofrimento na Doença no Cancro da Mama}

"Não é fácil viver com esta doença. Mas também não é fácil estar perto de um doente com cancro. Estar perto, dar espaço, perceber quando se deve abraçar, perceber quando se tem de deixar 'partir a loiça toda', saber ouvir, saber falar ... Quem vive de perto com o doente é um 'saco de pancada'".

(29 anos, mastectomizada)

\section{I.3.1.1. Sofrimento: definição e diferenciação de outros conceitos}

A palavra sofrimento é frequentemente referida em contextos de doença/doença, bem como, em situações de perda e luto. Em psicologia oncológica, na maioria das 
vezes o sofrimento é apenas e somente conceptualizado e descrito em termos clínicos e psicopatológicos. Fala-se em sofrimento psicológico na doença reportando-se aos distúrbios de ajustamento ao processo de doença, a respostas emocionais face à doença (ansiedade, stresse, depressão). Recorrentemente, quer na literatura de saúde, em geral, quer na literatura de psicologia, em particular, sofrimento e dor são utilizados como sinónimos. Menos frequente na atualidade, é a associação de sofrimento e angustia, esta protagonista essencialmente no âmbito da saúde mental e da psicologia clínica, e mesmo assim, atualmente substituída por novas terminologias. Assim, revela-se oportuno a definição e diferenciação destes três conceitos, bem como, a sua relação com a situação de doença.

O conceito de angustia foi muito utilizado na era psicanalítica, recentemente esquecido e substituído na psicologia moderna da era cognitivista, por conceitos mais cognitivos como ansiedade, stresse e a eles associado o coping, como forma de minimizar o a experiência de sofrimento.

O conceito de angustia apareceu no âmbito da patologia na segunda metade do século XIX. Até aí, era associado a medos irracionais ou paixões tristes. Em 1866 Morel descreve o quadro de "delírio emotivo", explicando um conjunto de perturbações ansiosas e depressivas. Mais tarde o conceito evolui para o de neuroastenia, caracterizado pela inquietação psíquica e pela presença de diferentes sensações corporais. Na obra neurose de angustia, Freud descreve diferentes manifestações de angustia: a inquietação crónica, o ataque de angustia, os equivalentes físicos, os medos ilegítimos e seletivos, denominados fobias e obsessões. É considerado um sintoma comum a diferentes perturbações psíquicas (Doron \& Parot, 2001). 
A Associação Psiquiátrica Americana (Manual de Diagnóstico e Estatística das Perturbações Mentais - DSM-IV) inclui a angustia nas perturbações da ansiedade. Na reformulação da teoria da angustia (na obra inibição, sintoma e angustia), Freud associa o conceito à experiência de desprazer, luto e dor. Definindo a dor como reação à perda do objeto, angustia como reação ao perigo que a perda representa e luto como elaboração da perda (Fleming, 2003).

Vallejo (1999) explica que a angustia aparece face a eventual ameaça da integridade do "eu" pessoal. Podendo ser desencadeada por circunstâncias diversas, das normais às patológicas. Ainda segundo o mesmo autor, a angustia normal explica-se, quantitativamente e qualitativamente, pelo estímulo desencadeante. Já a patológica é anacrónica (revive situações passadas), fantasmagórica (sua representação é imaginária), e estereotipada (repetitiva). Por estas razões é mais corporal, desproporcionada, persistente, menos adaptativa, acompanha-se de híper-ativação, afetando o rendimento e o funcionamento psicossocial e a liberdade da pessoa.

Sendo a doença um acontecimento disruptivo, cuja trajetória é suscetível de constituir ameaça à integridade física e psíquica, os doentes experimentam angustia. Daí a angustia poder ser considerada sinónimo de sofrimento, no contexto da saúde/doença.

A explicação para a indiferenciação dos conceitos dor, sofrimento e angustia, utilizados frequentemente como sinónimos, respetivamente no caso de dor e sofrimento, sofrimento e angustia, parece residir no facto dos três acompanharem o ser humano ao longo da sua existência.

Reflectamos agora na dor e no sofrimento, e na utilização recorrente como sinónimos no contexto da saúde/doença. Importa em primeiro lugar, definir e distinguir os dois conceitos. Segundo o Dicionário de Língua Portuguesa (1999), sofrimento 
deriva do latim sufferere, que significa, sofrer, suportar, por sua vez sinónimo de padecer, passar por, admitir, tolerar. Segundo o mesmo dicionário, dor significa sensação penosa ou desagradável. No Dicionário de Psicologia (2001), sofrimento é definido como estado mental que sente todo o indivíduo em presença de dor física ou mental prolongada. O mesmo dicionário, define dor como sensação resultante da estimulação dos recetores da nociceção. Prosseguindo defendendo que a dor no ser humano é um fenómeno neuropsicológico complexo, de natureza pluridimensional (sensorial, afetivo, cognitivo e comportamental). Para a Association International for the Study of Pain (IASP), dor é uma experiência sensorial e emocional desagradável, decorrente de lesões teciduais. Não obstante, ela pode-se manifestar na ausência de lesão tecidual (Teixeira, 1999). A dor encontra-se presente em cada um entre três, e em cada um entre dois doentes com cancro em tratamento, e por mais de três em quatro em estado de doença avançada (Gonçalves, 2011). E é responsável por grande parte do sofrimento dos doentes oncológicos.

Nem todo o sofrimento é provocado pela dor. No entanto, na atual cultura da medicalização, tende-se a descrever o sofrimento em termos de dor. Nem todas as pessoas que têm dor sofrem, e nem todas que sofrem têm dor. Uma mulher ao dar à luz tem dor, mas não sofre, alguém que perdeu um ente querido sofre (Bayés, 1998 ${ }^{\text {b }}$. O sofrimento é um fenómeno mais amplo que a dor. Esta é apenas e só referente às lesões teciduais ou sintomas somáticos, enquanto que o primeiro tem diferentes dimensões (Bayés, 2003b). Como descreve Victor Frankl (2008/1977) no livro Em busca de sentido, a propósito do sofrimento infligido no campo de concentração de Auschwitz:"(...) o sofrimento do ser humano é como algo em estado gasoso. Assim como determinada quantidade de gás preenche um espaço oco sempre de modo uniforme e integral, não importando as dimensões desse espaço, o sofrimento, seja 
grande ou pequeno, ocupa toda a alma da pessoa humana, o consciente humano" (p.63).

Guimarães-Lopes (1993) fala-nos do sofrimento como afeção, "algo que afeta". Explicando que sofrer deriva de subferre, sub significa "debaixo", e ferre de "levar a ", tratando-se assim, do movimento de resistência face a qualquer posição de inferioridade. Loser e Melzack (1999) descrevem o sofrimento como resposta negativa induzida pela dor, mas também pelo medo, ansiedade, stresse, perda de pessoas e objetos queridos e outros estados psicológicos. Chapman e Gravin (1993) definem o sofrimento como estado afetivo e cognitivo complexo e negativo, acompanhado da experiência de ameaça à integridade física e/ou psíquica, e sentido de impotência perante a perceção de inexistência de recursos psicossociais para lhe fazer frente. $\mathrm{O}$ sofrimento enquanto estado específico de mal-estar decorrente da ameaça à integridade físico, também é definido por Benito, Maté e Pascual (2011). Cassell (1991) na sua definição de sofrimento preconiza que este afeta a consciência de si mesmo, o sentido do passado, presente e futuro, a identidade pessoal e existencial e a preocupação com esta mesma identidade. Bayés $\left(1998^{\mathrm{a}}\right)$ sublinha, por sua vez, que todo o sofrimento é emocional, sejam as causas biológicas, cognitivas, sociais ou ambientais. Oliveira (2007, 2009) situa o sofrimento humano muito para além da dor, sublinhando que com a dor nada há a aprender, já com o sofrimento sim. Ramón Bayés (2010), psicólogo da Universidade Autónoma de Barcelona, (já citado anteriormente, reconhecido internacionalmente pelos trabalhos científicos no âmbito da psicologia do sofrimento, por esse motivo será uma referência frequente neste trabalho) adjetiva que a morte e o sofrimento fazem parte da vida, por essa razão, deverão ser objeto de estudo da psicologia. Em todo o mundo ocidental, apesar da paz, riqueza e aumento da longevidade, o sofrimento não foi banido do mundo (Bayés, 1998ª). 
Apesar de diferentes, tendemos a utiliza-los como sinónimos. Falamos de dor quando nos referimos à dor do parto, à dor do pós-operatório (dor física), mas referimonos igualmente a ela para falar da perda de um ente querido, de um projeto desfeito, de um amor perdido (Paulo, 2006).

Esta indiscriminação conceptual entre sofrimento e dor poderá dever-se às teorias dinâmicas da psicossomática, defensoras da relação biunívoca entre mentecorpo, ou entre psique-soma. Assentes no paradigma dos sofrimentos da alma/psique doerem na carne/corpo. (Bortello, 2000, cit. por Fleming, 2003) num artigo sobre "dor corporal - sofrimento psíquico: uma antinomia?", discute precisamente a continuidade/descontinuidade do modelo psiquismo-soma. $\mathrm{O}$ sofrimento acontece na carne, defende António Damásio (1995), prestigiado neurocientista luso-americano, no livro "O erro de Descartes".

Fleming (2003) reforça que apesar das duas palavras terem origens etimológicas diferentes, dor do latim dolor-doloris (romper, rasgar, abrir fenda), em que dolo significa "eu rompo", e sofrimento também do latim sufferentia, sufferere (tolerar, suportar, aceitar), ambos os termos significam afetos, emoções básicas que se exprimem na área transicional da experiência corpo/mente. Podemos assim dizer, que sempre que há dor há sofrimento, porém, pode haver sofrimento sem dor. Podemos ainda falar de dor física, quando nos referimos à dor no corpo, dor somática, e em dor mental, no caso da dor psíquica.

Chapman e Gravin (1999) falam do sofrimento como ameaça à integridade de si mesmo, e de dor de ameaça á integridade física. Porém, acrescentam, o grau de ameaça ao dano percebido depende em grande parte da perceção/interpretação que cada pessoa faz da sua experiência de dor, justificando assim, porque ambos os conceitos aparecem 
frequentemente relacionados. Cassell (1991), por sua vez, acrescenta, que o cérebro ativa as mesmas zonas perante a dor neciceptica (física) e dor emocional, daí a associação. A dor resulta da união mente/corpo, da "sensação" de dor, dependente dos processos neuronais fisiológicos que captam e transmitem o sinal doloroso aos centros cerebrais, e a perceção de ameaça/dano, função mental do cérebro. Daí o conceito de "dor total", que para além das dimensões biológica e mental, descritas acima, se acrescentam a social, familiar e espiritual (Jairo, Vélez \& Kikorian, 2008).

Todavia, em jeito de conclusão, apesar de diferentes, como foi explanado anteriormente, ambas fazem parte da vida, estando presentes em algum momento da trajetória desenvolvimental. Quem não sentiu dor aquando da fratura de um membro, de um processo inflamatório, da recuperação de intervenção cirúrgica. A dor apesar de desagradável, exerce um papel importante na sobrevivência, pois desempenha uma função protetora para o organismo (Guimarães, 1999). Também o sofrimento é existencial à condição humana, sofre-se quando se rompe uma relação amorosa, quando perde um ente querido, quando se perde o emprego, quando a doença aparece ou atinge a família. Dor, sofrimento e morte são universais (Bayés, 2003 ). O sofrimento é consequência da valorização pessoal e subjetiva de algo ameaçador à existência e integridade humana. Não obstante, a persistência do sofrimento, acompanhada de estado de ânimo concreto, pode evoluir para ansiedade, depressão, hostilidade ou ira. Todavia, não deverá ser confundido com distúrbio emocional ou de humor (Bayés, 1998º). 


\section{I.3.1.2. Experiência subjetiva de sofrimento na doença}

"Quem eu era, e o que sou agora com a doença ...". (68 anos, tumorectomizada)

Sabemos que a doença é fonte de sofrimento, não a única, mas como refere Gameiro (1999), uma das formas mais evidentes de sofrimento. Porque provoca dor, mas também, porque constitui uma ameaça real ou imaginária à integridade da pessoa, relembrando-lhe a sua fragilidade, e aproximando-o da ideia de morte. McIntyre (1995a) define o sofrimento na doença como "um estado de desconforto que envolve uma perda ou ameaça de perda a nível da identidade e integridade do indivíduo e uma alteração da sua perceção de futuro" (p.21). Por isso, perda e sofrimento na doença encontram-se relacionados (McIntyre, 2004). As significações pessoais a ele atribuídas e a carga afetiva correspondente, são suscetíveis de modificar o curso desse sofrimento (McIntyre, 2004). Para McIntyre (1995 $)$, o sofrimento da pessoa doente não se restringe aos sintomas da doença e do corpo. A doença acontece numa pessoa que sofre, sendo o sofrimento físico apenas uma dimensão desse sofrimento (Gameiro (1999; McIntyre (1995ª). O sofrimento é um fenómeno biopsicossocial, envolve a pessoa no seu todo, e é de natureza multidimensional (McIntyre, 2004). A doença afeta várias dimensões da pessoa (corpo, identidade, relações familiares sociais, emprego, dimensão espiritual, entre outras). O sofrimento a ela associado relaciona-se com perdas sofridas ou antecipatórias verificadas nas diferentes dimensões da vida da pessoa. McIntyre e Gameiro (1999) apresenta-nos quatro dimensões da experiência de sofrimento na doença, o sofrimento físico, referente a queixas de dor, desconforto e perda de vigor 
físico; sofrimento psicológico, respeitante a alterações cognitivas e alterações emocionais; sofrimento sócio-relacional, aludindo a alterações afetivo-relacionais e alterações sócio-laborais; e sofrimento existencial, evocando alterações da identidade pessoal, alterações do sentido de controlo, limitações existenciais e limitações no projeto de futuro (Gameiro, 1999; McIntyre, 2004).

A intervenção médica deverá também atender ao sofrimento do doente nas outras dimensões da sua vida, caso contrário, compromete o sucesso terapêutico. No caso da psicologia, sendo um dos objetivos da Psicologia da Saúde investigar e intervir nos aspetos psicológicos da doença, do comportamento do doente e da relação médicodoente, o sofrimento do doente está na encruzilhada destes aspetos (McIntyre, 1995 $)$, e fundamentalmente por esta, não deverá ser descorado.

Encontramos igualmente algumas indefinições e sobreposições relativamente ao termo sofrimento na doença. Conceitos como "impacto psicossocial da doença", "representações de doença”(McIntyre, 1999, in prefácio Gameiro, 1999), "sofrimento psicológico na doença", "morbilidade psicológica” na doença, associam-se recorrentemente ao sofrimento na doença. Estes conceitos operacionalizam apenas alguns domínios do sofrimento na doença, e não a experiencia de doença na sua totalidade. Por outro lado, a experiência de sofrimento na doença não se reduz à morbilidade física e psicológica do doente, envolvendo uma vivência mais alargada, envolvendo as dimensões psicossocial (familiar, laborar, lazer e recreativa), existencial e espiritual. A experiência de sofrimento é uma experiência "despatologizada" (McIntyre, 1999, in prefácio Gameiro, 1999). Ou seja, a perda e reações à perda associadas ao processo de doença, causadoras do sofrimento, são aspetos normais do ajustamento ao processo de doença (McIntyre, 2004). 
Para Gameiro (1999) o sofrimento na doença, é classicamente abordado na perspetiva do "estar doente", ou seja apresentar um conjunto de sintomas, correspondentes a determinado diagnóstico, face ao qual se indica um determinado tipo de tratamento. No entanto, defende o autor, é necessário atender à experiência subjetiva de sofrimento na doença, à vivência do “sentir-se doente”. É nesta dimensão, sublinha, que nem sempre, ou quase nunca, são atendidos os cuidados ao doente.

A medicina foi desenvolvida para cuidar, aliviar, tratar e curar o sofrimento humano. $\mathrm{O}$ avanço da biologia molecular e da tecnologia tem sido responsável por prolongar a longevidade das pessoas. Como contrapartida, assistimos ao aumento das doenças crónicas, e à perpetuação do sofrimento dos doentes com controlo da doença, através da ministração continuada dos tratamentos. Estas duas realidades favorecem a assistência médica centrada mais na dor em detrimento do sofrimento do paciente (Oliveira, 2009). A assistência à dor pela prescrição de medicamento é mais económica, já a escuta do sofrimento do doente, fica, não raras vezes, para segundo plano. Resultando assim, numa assistência eficaz da medicina à dor, mas ainda, deficiente ao sofrimento.

Oliveira $(2007,2009)$ justifica esta limitação médica pela formação essencialmente bioquímica dos médicos, que serve apenas convenientemente a pesquisa científica, mas se revela insuficiente no exercício da medicina clínica. O modelo biomédico condiciona os médicos à dificuldade em olharem, tocarem e escutarem os doentes, enquanto diagnosticam e prescrevem. É verdade, que desde a década de 70 se iniciou o movimento da humanização da medicina. Alguns avanços foram feitos nesse sentido, no entanto, ainda existe um longo caminho a ser feito. A autora continua, defendendo que as competências relacionais/comunicacionais, empáticas e éticas para com o sofrimento 
dos doentes, são responsáveis por classificar o clínico de bom médico, e mais, de médico bom.

O sofrimento do doente, enquanto experiência subjetiva do processo de doença, tem sido objeto de reflexão fenomenológica e existencial (McIntyre, 1999, in prefácio Gameiro, 1999). E é nessa perspetiva, segundo a autora, que faz sentido ser enquadrado e analisado. Dentro deste quadro, ele pode ser encarado como um processo pessoal, acompanhado de um conjunto de significações subjetivas. Pode ainda ser encarado como um valor, possibilitando o crescimento e a transformação interior (Gameiro, 1999; McIntyre, $1995^{\mathrm{b}}$ ). Assim, o sofrimento na doença pode reunir aspetos positivos para o doente, o sofrimento como um desafio, o sofrimento como possibilidade de reconstrução do self, o sofrimento como busca de novos significados para a vida $\left(\right.$ McIntyre, 1995 $\left.{ }^{b}\right)$. Experiências positivas são frequentemente descritas por doentes com cancro, após termina a jornada do processo sofrido de doença, algumas delas partilhadas em forma de livro autobiográfico.

Falar de sofrimento na perspetiva do doente, é falar da sua experiencia de sofrimento na doença. O termo "experiência de doença" gera ainda pouco consenso e alguma polémica. Quer na sua definição, bem como, na sua operacionalização e estudo (Alves, 1993). Segundo McIntyre (1995') para compreendermos a experiência de doença temos de ir para além da experiência objetiva da doença, passando para a experiência subjetiva desta. Dela depende a forma como as pessoas avaliam e reagem a ela. Tavares e Trad (2005) defendem que a compreensão da doença é estudada em duas perspetivas, 1). Perspetiva individualista - redução do comportamento perante a doença a questões psicológicas; 2). Perspetiva coletivista - a explicação enfatiza os aspetos culturais, como as diferentes crenças, valores e atitudes face à doença, em função dos diferentes grupos, classes sociais, faixa etária e etnia. Porém, continuam os autores, 
ambas as perspetivas salvaguardam que a compreensão da doença consiste na experiência, enquanto resultado de uma interpretação, que adquire sentido à medida que vai sendo interpretada. O significado da doença e da experiência de doença variam de pessoa para pessoa, em função dos recursos que cada um possui para lidar com ela: personalidade, coping, energia, situação económica, apoio social, entre outros. Ao significado do próprio, junta-se o significado sócio-cultural atribuído à doença, segregando, estigmatizando ou protegendo quem dela padece (Paúl \& Fonseca, 2001).

A doença como experiência subjetiva manifesta-se nas histórias de vida particulares e significativas, na estruturação, desestruturação e reestruturação da identidade pessoal e social dos doentes ameaçada pela situação de doença. A experiência de doença objetiva-se na relação com a doença, na relação entre médico doente, entre o doente e os que o rodeiam, na relação com outros doentes (Maia, 2009).

Através da interpretação da sua experiência de doença, a pessoa doente adquire um sentido para a compreensão da sua doença. Esse significado interfere com o processo de enfrentar e se adaptar às diferentes fases da doença e dos tratamentos (Anjos \& Zago, 2006).

Para as pessoas com doenças crónicas os problemas mais associados à experiência de doença são a restrição e o isolamento social, a desvalorização do $E u$, o constituírem um fardo para os outros, nomeadamente, para os familiares próximos. O projeto de vida individual é assim abruptamente alterado. Por forças da mudança no curso da vida, frequentemente, o rendimento económico dos doentes e família é significativamente afetado, sendo fonte de preocupação e sofrimento (Paúl \& Fonseca, 2001). Pelo facto de ser associada ao sofrimento, dor e morte, a doença oncológica é temida em diferentes culturas (Trill, 2002). 
Os significados dos doentes sobre a sua doença poderão não ser compatíveis com os significados do médico. Aprofundar o conhecimento acerca das significações de doença é uma tarefa essencial na indicação de intervenções psicológicas relevantes com vista à orientação terapêutica (Aguiar \& Fonte, 2007). A análise das narrativas é defendida por alguns autores como um meio privilegiado de exploração das significações de doença, por um lado, possibilitam a construção de sentido à experiência, permitindo organizá-la, por outro (Aguiar \& Fonte, 2007). Para Favoreto e Cabral (2009), também a análise da narrativa é fundamental para o conhecer a forma como os pacientes dão voz aos seus sofrimentos. Pois a compreensão do paciente enquanto personagem do seu próprio adoecer, é importantíssima na prestação de cuidados. A forma como a pessoa vive a sua doença, o significado por si atribuído, exercem influência no comportamento de doença, a relação com os profissionais de saúde e com os outros (Trill, 2002).

Apesar da sua pertinência, os trabalhos sobre a experiência subjetiva de sofrimento na doença, mas dimensões descritas, são ainda escassos. Pelo que se defende a necessidade premente da sua realização (McIntyre, 1999, in prefácio Gameiro, 1999). Não obstante, foram encontrados alguns realizados com doentes crónicos, oncológicos e com doentes com cancro da mama, que passamos a referenciar.

Gameiro (1999) no estudo de validação do Inventário de Experiências Subjetivas de Sofrimento na Doença, aplicado numa amostra de 125 doentes, distribuídos pelas seguintes categorias clínicas: cirurgia, ortopedia e ortotraumatologia e medicina interna, observou que indivíduos com maior afeção física e/ou psicológica experienciam mais sofrimento. Constatou ainda que a dimensão experiências positivas de sofrimento se aproxima da noção "espírito de luta", como forma de coping. Os doentes que experienciaram a doença ou internamento mais recentemente evidenciam 
mais sofrimento. A partir das queixas e sintomas físicos, foi inferido maior sofrimento nos homens, comparativamente com as mulheres.

Segundo Bento (2000), utilizando o mesmo instrumento, doentes internados nos cuidados intensivos, apresentam mais sofrimento sócio-relacional, seguido de sofrimento psicológico e por último existencial. Indicando que estes doentes pela severidade da patologia e pela necessidade exigente de cuidados, experimentam sofrimento intenso na doença. Em pacientes com dor crónica o sofrimento físico aparece como a dimensão mais afetada na doença, seguido do sofrimento psicológico, sócio-relacional e existencial (Araújo-Soares \& McIntyre, 2000). Também em doentes com esclerose múltipla apresentam valores de sofrimento muito elevados, de forma mais expressiva no sofrimento sociorelacional, e baixos níveis de otimismo/esperança. A cronicidade da doença parece associar-se a uma experiência de sofrimento mais intensa na doença. E que outras variáveis como a idade, género, estatuto laboral, estádio da doença, entre outras, influenciam igualmente a experiência subjetiva de sofrimento. McIntyre (2004) sublinha que frequentemente o sofrimento nestes doentes se manifesta sob a forma de sintomas depressivos, de natureza clínica ou não, tratando-se de estado reativo face às exigências da doença e tratamentos e pelas consequentes perdas a eles associados.

Para Sobral (2006) o sofrimento encontra-se diretamente associado à perceção de doença. Segundo o autor, a perceção de elevado controlo pessoal e a crença na eficácia dos tratamentos minimizam o sofrimento. Já a presença de sintomatologia intensa, perceção de consequências elevadas, elevada representação emocional e longo período de doença, intensificam o sofrimento. Resultados concordantes foram encontrados por Ribeiro, Pereira e Cunha (2012) numa amostra de doentes com dor oncológica. 
Um estudo qualitativo levado a cabo por Aguiar e Fonte (2007), no qual pretendiam aceder às significações (significado, crenças e representações) da criança com diabetes Mellitus face à sua doença, verificaram que o significado atribuído pelas crianças à sua doença é um fator central nas suas experiências de vida. A doença já faz parte das suas vidas. Concluíram ainda, que essas significações são influenciadas pela socialização pela cultura na qual a criança se insere.

Paulo (2006) num trabalho sobre as vivências da dor e do sofrimento na pessoa com doença oncológica em tratamento paliativo, com base na análise categorial dos relatos dos participantes, revelou que o sofrimento dos doentes é resultante das relações com os profissionais de saúde, com os amigos e conhecidos e familiares; do continuo esperança/desesperança; perda de continuidade; do confronto com a doença; da perda de controlo e da ausência de suporte social.

Pereira (2008) com base na análise das comunicações verbais e não verbais de mulheres com cancro da mama, verificou que as queixas que representam maior sofrimento para as doentes são: 1). preocupação/medo e insegurança relativamente ao diagnóstico e prognóstico: imagem corporal, procedimentos terapêuticos, sofrimento físico, limitações corporais e realização de exames; 2). sentimento de perda: de uma parte do corpo, integridade física, imagem corporal, auto-estima, autonomia, atividades de lazer, perda da vinha que tinham; 3). dureza da fase dos tratamentos: quimioterapia náuseas, vómitos, diarreia, obstipação, cefaleias, cansaço, entre outros; radioterapia queimaduras e alterações cutâneas.

A autora acrescenta ainda, a propósito de um estudo sobre comunicação de más notícias e gestão do luto em doentes com cancro da mama, que a comunicação médicopacientes se processa sobe o paradigma "médico responsável-doente passivo", na qual a 
participação das doentes e familiares é pouco valorizada, a informação escassamente partilhada, nomeadamente no que diz respeito a informação dolorosa ("más notícias"), a palavra "cancro" e "tumor" era evitada, pouca disponibilidade para esclarecer doentes e familiares, e as doentes não eram motivadas a participar na decisão terapêutica. Observou ainda, que a e relação/comunicação médico-pacientes ficava comprometida pelas interrupções das consultas médicas, de enfermagem e de outras especialidades, pelos atendimentos telefónicos, entrada de profissionais de saúde e auxiliares de ação médica, violando a privacidade da relação terapêutica. A autora constatou debilidades na área da comunicação na generalidade dos profissionais de saúde. Estas observações demonstram, por um lado, o desrespeito pela experiência de sofrimento das doentes e o agravamento da mesma, e por outro, a violação de um dos direitos fundamentais dos doentes, o direito à informação, levantando assim questões acerca da funcionalidade da bioética em medicina.

Resultados concordantes foram encontrados por Dias (2005), também em doentes com cancro da mama, ao longo da cadeia processual médica. A desinformação, encobrimento e "obscurantismo informativo" em determinados momentos, nomeadamente relativamente a decisões terapêuticas e gravidade da situação (prognóstico). Evitamento e cautela em proferir a palavra cancro. A assinatura do "consentimento informado", expressão de concordância com os procedimentos terapêuticos a adotar, é, não raras vezes, realizada sem sustentabilidade informacional ou em informação imprecisa. Em alguns casos, o doente apresenta ignorância completa sobre a doença e o curso da mesma. Trill (2002) e Freitas e Souza (2004) fazem alusão a resultados semelhantes.

A ambivalência e incerteza infligida pela deficiência da comunicação médica resulta em sofrimento para os doentes e família e, em alguns casos, experiência emocional de 
stresse, entre outros sintomas. Shofield, Butow, Tattersall, Beeney e Dunn (2003) encontraram sustentabilidade científica na relação entre a comunicação do diagnóstico de cancro e a incidência de sintomas psicológicos. Os autores defendem que a ansiedade pode ser diminuída se o doente for previamente preparado para o diagnóstico; se for fomentada a presença, aquando do mesmo, de figuras significativas para o doente; se fornecidas todas as informações e esclarecidas todas as dúvidas e questões; se forem escutados os sentimentos do doente; desta forma atua-se em prole da tranquilização do doente em sofrimento. Também a depressão pode ser minorada, continuam os autores, se não houver pudor na utilização da palavra cancro, se a gravidade da situação não for ocultada, se o doente for convidado a participar ativamente no tratamento.

Silva (2008), estudou o sofrimento psicológico na mulher com cancro da mama, constatou que o sofrimento da mulher com cancro da mama transcende o sofrimento da doença em si. O seu sofrimento agrega as representações e significados culturais femininos atribuídos à doença, suscetíveis de interferir com os relacionamentos interpessoais, especialmente, mas mais íntimas e básicas da mulher.

Um estudo qualitativo levado a cabo por Costa, Jiménez e Pais-Ribeiro (2010) de análise de conteúdo das narrativas de doentes transmontanas sobre os acontecimentos de vida significativos decorrentes do cancro da mama, permitiu verificar que os acontecimentos com impacto mais significativo na experiência de doença são a diminuição da funcionalidade nas atividades laborais e atividades instrumentais da vida diária, e consequente sobrecarga dos familiares, alterações na relação corporal, sexual e conjugal.

Mariela Michelena (2010) psicanalista freudiana, doente oncológica na mama, no livro auto-biográfico do seu processo do adoecer "À noite sonhei que tinha peitos", 
descreve da seguinte forma o sofrimento na doença: “(...) Em troca de otimismo, dou verdade. Sou a voz da dor, a voz do sofrimento a que todos os que passam por esta doença têm direito “ (p.236).

Um estudo realizado por Apóstolo, Batista, Macedo e Pereira (2006) com o propósito de avaliar o conforto e o sofrimento em mulheres com cancro da mama e ginecológico, submetidas a tratamento quimioterapêutico, revelou baixos níveis de conforto físico e valores elevados de sofrimento emocional, referente à preocupação com o impacto da doença nos familiares mais próximos.

Anjos e Zago (2006), com o objetivo de conhecer a experiência da terapêutica quimioterápica na visão de uma doente com cancro da mama, constataram que o significado da experiência de quimioterapia neste caso foi de "perda de controlo da vida”.

Rodrigues, Cunha e Pereira (2012) num estudo comparativo entre mulheres mastectomizadas e histeroctomizadas utilizando o Inventário de Experiências Subjetivas de Sofrimento na Doença (IESSD) constataram que as primeiras apresentam mais sofrimento psicológico e sócio-relacional que as segundas e têm menos experiências positivas no sofrimento que as segundas.

Como vimos anteriormente, o estudo da experiência subjetiva de sofrimento na doença reveste-se de grande importância, no sentido de possibilitar melhor compreensão da forma como os doentes vivenciam a experiência de doença, por forma a serem planeadas e realizadas intervenções psicológicas que aliviem o sofrimento de doentes e família, promotoras da adaptação ao processo de doença, adesão terapêutica, com repercussões na qualidade de vida dos doentes e famílias. Verificamos igualmente, que 
todavia, é um tema ainda pouco investido empiricamente, e em alguns casos, até clinicamente, em Portugal. A sua continuidade é necessidade urgente.

\section{I.3.2. "Cuidar " e "aliviar" o Sofrimento na Doença}

"Conheça todas as teorias, domine todas as técnicas, mas ao tocar a alma humana seja apenas outra alma humana"

(Carl Gustav Jung)

\section{I.3.2.1. Cuidar e aliviar o sofrimento: tarefa do sistema de saúde e dos profissionais} de saúde

"Quando sentimos dor vamos mais baixo ..." (40 anos, cirurgia conservadora)

A doença acontece na vida das pessoas, sendo o seu tratamento assegurado pelos hospitais. É possível desenvolver uma rede de hospitais sem dor, mas é impossível conceber um único hospital sem sofrimento (Arranz, Barbero, Barreto \& Bayés, 2008). Dor e sofrimento, segundo Jairo, Vélez e Kikarian (2008), cujo alívio é tarefa primordial dos profissionais de saúde, continuam a sofrer da visão dualista cartesiana. Professores e alunos das universidades de medicina, investigadores e profissionais de saúde continuam a pesquisar, diagnosticar e a atender somente aos organismos doentes, descorando as pessoas que sofrem (Bayés, 2009). Universidades e hospitais universitários continuam a ensinar apenas os seus alunos a examinar organismos e comportamentos e não pessoas, a diagnosticar e a tratar doenças e patologias, e não o sofrimento. A tratar e a curar a doença e não a pessoa (Simões, 2008). Como refere 
Carvalho (1996) "não é a doença ambulante que se desloca ao médico, mas o homem que sofredor que busca ajuda, alivio para o seu sofrimento” (p. 14). A medicina encontra-se ainda muito enraizada no modelo biomédico, preconizado pelo dualismo corpo-mente, focalizando na visão compartimentada do sofrimento confinado, apenas e só, aos sintomas físicos e à experiência de dor. Descorando que o uso de técnicas médicas avançadas, por vezes, não só fracassa o alívio do sofrimento, como ainda o inflige (McIntyre, 1995a). Verificando-se assim, um conflito de "vozes" no modelo médico do cuidar, a "voz da medicina" e a "voz da vida", ou seja, da experiência subjetiva dos doentes (McIntyre, 2004).

Os cuidados paliativos oncológicos são o contexto onde mais se tem atendido à relação dor e sofrimento e seu alívio. Porém, esta atenção deverá fazer igualmente parte dos cuidados prestados ao doente nos outros ciclos processuais da doença oncológica (Jairo, Vélez \& Kikarian, 2008).

Lobo-Antunes (2008), prestigiado neurocirurgião em Portugal e nos Estados Unidos, reitera que a função do médico não se esgota na prescrição de receitas, devendo também minimizar as dores do corpo e da alma dos pacientes. Defensor da humanidade da medicina e dos cuidados de saúde, vê na empatia dos profissionais de saúde para com o doente a chave desse processo. Por isso, sublinha, o doente tem o "seu" médico, e este o "seu" paciente.

Para Bennett (2002) recolher informação para realização de diagnóstico e fornecer informação ao doente por forma a compreender o seu problema de saúde, são elementos fundamentais na prestação de cuidados em saúde. A ausência desta comunicação deverá ser uma preocupação em saúde. Sabemos que o sofrimento na doença é provocado por múltiplos fatores, entre eles, e principalmente, a ausência e 
clareza de informação sobre o estado da doença. McIntyre $\left(1995^{a}\right)$ relata um caso documentado num jornal americano em 1994, de um doente com um quadro leucemia de bom prognóstico, que piorou rapidamente após ter descoberto o seu diagnóstico, depois de consultar as notas do médico sem que este desse conta. Nunca havia sido informado pelo seu médico sobre o diagnóstico e prognóstico favorável. O doente faltou à consulta seguinte e morreu duas semanas depois. Os comentários ao ocorrido por psicólogos, entre eles o presidente da American Psychological Association, apontam no sentido de que a descoberta do diagnóstico desenvolveu cognições da natureza catastrófica sobre a doença e sentimentos de incontrolabilidade e impotência, numa experiência que a autora denomina de sofrimento antecipatório. Segundo explica a autora, o doente não morreu da doença, mas do sofrimento provocado por esta.

Anatole Brayand (cit. por Bayés, 2004), crítico literário do New York Times, relatando a sua experiência de doença num hospital universitário norte-americano, descreve: "para o médico típico, a minha doença é um simples incidente na sua rotina quotidiana, mas para mim, é a crise da minha vida"(p.120).

O doente não é apenas uma entidade biológica, nem a doença apenas uma disfunção, ala acontece num corpo de alguém singular, com um passado, um presente e um futuro, com um percurso ontológico. O corpo é um espaço relacional, intra e interpessoal. É o suporte físico da existência, o interface entre o pessoal, o social, o cultural e o histórico (Maia, 2009). O corpo ganha uma importância fundamental nos doentes oncológicos. Ele é o palco de todos os acontecimentos e sofrimentos. Desde os exames ao diagnóstico, passando novamente por exames prévios à realização dos tratamentos, os tratamentos (cirurgia, quimioterapia, radioterapia, entre outros), e depois dos tratamentos (mutilações, limitações e disfunções corporais). Na trajetória da doença, o corpo sofre perfusões, transfusões, transformações, mutilações, dilacerações, sendo 
estes "cortes" na carne vividos como "cortes" na alma. O corpo ocupa assim o centro da atenção dos médicos, da sua preocupação, medo, repulsa, dor e sofrimento. Numa relação, não raras de vezes, de amor/ódio. Os doentes com cancro sofrem no corpo dores e sofrimentos, agravados ainda pela cegueira dos profissionais de saúde em atender não ao corpo, mas ao "seu corpo". Mas também porque o paciente sofre por ter medo de ficar com sequelas, incapacitado, com perdas materiais e sociais, pelo medo da morte, sendo na conceção de Sasdelli e Miranda (1992), o corpo, por ser alvo e sinal, o continente desse sofrimento.

Herllich (2004), citando o antropólogo Marc Augé (1984) explica que o "grande paradoxo da experiência de doença é que ela é tanto a mais individual, quanto a mais social das coisas" (p.385). Tornando-se imprecisa a sua demarcação no domínio privado ou público. No entanto, esclarece o autor, o corpo ainda pertence ao domínio privado.

Já em 1982, Cassell chamava a atenção para a afirmação “ os que sofrem não são os corpos, mas sim as pessoas". Explica o autor, as pessoas que padecem de dor, sofrem quando sua origem é desconhecida, quando creem que não pode ser aliviada, quando é percebida como uma ameaça. A pessoa sofre, quando significa um físico ou psicossocial como ameaça à sua integridade física ou psíquica; quando acredita não possuir recursos para fazer frente á ameaça. Para Cassell (1982), o que origina o sofrimento não são os factos, mas o significado atribuído pelo doente aos mesmos. Não existem doenças sem doentes (Bayés, 1998 ${ }^{\mathrm{a}}$ ).

Binino (2007) partindo da sua própria experiência de doença, conta-nos que todos os doentes sentem necessidade de falar sobre a sua doença. Exemplo disso são as conversas desenvolvidas sobre o processo da mesma entre doentes nas salas de espera 
das instituições de saúde. Segundo a autora "narrar uma doença a médicos ou enfermeiros, mas também aos próprios familiares amigos e até mesmo a desconhecidos, torna-se uma forma de reencontro consigo mesmo e com as próprias possibilidades de desenvolvimento" (p. 103). No entanto, profissionais de saúde, e por vezes, familiares e amigos, ainda pensam o contrário.

Segundo explica Bayés (2004), quer no relato, quer na avaliação subjetiva, os pacientes não se referem tanto à dor, mas sim e recorrentemente ao sofrimento, relacionado com a comunicação deficitária com os profissionais de saúde, nomeadamente médicos, e com os tempos de espera. Os tempos de espera sem informação, a ausência ou insuficiência de informação, o não sentirem escutados, o sentirem-se como objeto da medicina. Os tempos de espera, explica o autor, são uma das principais fontes de sofrimento nos doentes com cancro. Os tempos subjetivos são diferentes dos cronológicos, sendo igualmente diferentes dos tempos dos profissionais de saúde. Para os doentes e família são tempos de sofrimento.

Bayés $\left(2003^{\mathrm{a}}\right)$ reivindica a importância de se atender ao fator tempo nos cuidados oncologia, pois este produz impacto profundo no sofrimento nos doentes. Os tempos em oncologia são intermináveis, na perspetiva dos doentes e familiares: 1). Desde o aparecimento dos primeiros sintomas até à procura do médico; 2). a espera que precede os diferentes exames de diagnóstico; 3). a espera dos resultados dos mesmos; 4). a espera da comunicação do diagnóstico; 5). a espera do início dos tratamentos; 6). a espera pelos efeitos dos tratamentos; 7). a espera por novos exames, etc. Decorrem horas, dias, semanas, meses e anos vivenciados com grande sofrimento. A vivência subjetiva do tempo difere entre doentes e profissionais de saúde. Para os primeiros, o tempo é sempre de espera, e quanto mais incerta a espera, piores as expectativas e maior sofrimento. Para os últimos, o tempo tem o significado $\mathrm{d}$ de bons diagnósticos e 
tratamentos eficientes. O alívio do sofrimento associado aos tempos de espera dos doentes com cancro é impreterível.

Contudo, a medicina prossegue numa atitude de ver o sofrimento apenas quando pode ser diagnosticado, avaliado do ponto de vista clínico e patológico. O sofrimento existencial dos doentes continua ser descorado.

Bayés (2009) justifica o facto, talvez pela causa do sofrimento de uma pessoa diferir da de outra. Prossegue colocando a questão - o que é uma pessoa? Responde, a pessoa não é um organismo, não é a mente, não é o cérebro, e também não é um produto bio-psico-social. A pessoa, continua, "é o resultado final do funcionamento do seu cérebro, da sua história individual face a contextos físicos, culturais, sociais e afetivos específicos, através da linguagem e de outras formas de comunicação. Em suma, a pessoa é o produto singular da sua biografia" (p.13). O autor acrescenta ainda, que ao não tratarmos os pacientes, alunos e sujeitos de investigação como pessoas, pode ser explicado por falta de competência e/ou de vocação, ou porque nos sentimos incómodos na presença do sofrimento.

Na opinião de McIntyre (1995 ), o sofrimento dos doentes constitui um desafio para os profissionais de saúde na sua forma de "lidar com". A questionarem as conceções de doença e de cura, o seu papel nos cuidados ao doentes e na relação com este, e fundamentalmente, no papel que a humanidade tem na sua pessoa e na função profissional.

Talvez o incorreto atendimento ao sofrimento na doença encontre justificação, entre outras coisas, no facto do conceito continuar a carecer de definição consensual, operacionalizável, de significado unívoco e de instrumentos normalizados e aferidos, de medição objetiva (Bayés, 1998 ${ }^{\mathrm{a}}$ ). 
Krikorian, Limonero e Maté (2011), numa revisão de literatura nos principais motores de busca encontraram 145 artigos sobre as diferentes dimensões do sofrimento. Foram encontradas e descritas quatro dimensões do sofrimento. A dimensão física do sofrimento relaciona-se com a presença de sintomas (dor, fadiga, anorexia, insónia, dispneia, obstipação, confusão mental). Em diferentes artigos os sintomas físicos apareceram correlacionados com a ansiedade e a depressão. E em muitos deles, a dimensão física, era a dimensão do sofrimento mais afetada. De uma forma geral, na literatura consultada, os doentes distinguiam dor de sofrimento.

$\mathrm{Na}$ dimensão psicológica o sofrimento aparece relacionado com questões de mudança do estilo de vida (perda do emprego, aparência, dependência, impotência, limitações físicas), desesperança, prolongamento da vida e procura de significado. Os aspetos afetivos mais encontrados nesta dimensão foram a ansiedade, depressão, o coping e a percepção de auto-controlo.

$\mathrm{Na}$ dimensão espiritual/existencial, a espiritualidade apareceu frequentemente associada positivamente com a experiência de doença, qualidade de vida, bem-estar e funcionamento psicológico. Os doentes faziam referência nesta dimensão às palavras: paz, esperança, dignidade e religião. Em alguns estudos a dor espiritual foi utilizada como metáfora para o sofrimento.

A última dimensão encontrada, a social, integra as variáveis sócio-culturais relacionadas com o sofrimento do doente e família. Os autores concluíram que o sofrimento é individual e único a cada pessoa. Defendem a avaliação do sofrimento atendendo á sua complexidade, multidimensionalidade e à subjetividade dos sintomas e experiência. Consideram que o conhecimento profundo da natureza do sofrimento e dos fatores associados são fundamentais para o seu alívio. 
O conceito de sofrimento a par dos conceitos de experiência e significado da doença variam de pessoa para pessoa, podendo esta variabilidade ser explicada em função da diversidade dos recursos pessoais - tempo, energia, dinheiro, apoio social, personalidade, entre outros, bem como, pelo significado cultural atribuído a determinada doença, que a (des)valoriza mais ou menos, estigmatiza, segrega ou protege (Paúl \& Fonseca, 2001).

Segundo Cassell (1982), as pessoas com dor sofrem, quando a sua origem é desconhecida, quando acreditam ou temem que não pode ser aliviada, quando é percebida como ameaça. Ou seja, a dor física transforma-se em sofrimento, quando um dano importante afeta a nossa existência, provocando temor pela sua prolongação no tempo, intensificação e a sua falta de controlo.

Os hospitais existem apenas e só para cuidar dos doentes e aliviar as suas dores e sofrimentos (Bayés, 1998 ). Por outro lado, como preconiza Bayés (2010), a medicina não é exclusiva dos médicos, mas de todos os profissionais de saúde (psicólogos, enfermeiros, psiquiatras, farmacêuticos, trabalhadores sociais), pois todos trabalham com pessoas doentes, podendo cada um, com os meios que lhes são específicos, aliviar a dor e o sofrimento. Pensamento concordante é partilhado por McIntyre (1995), ao defender que aliviar o sofrimento no doente é preocupação ética de todos os profissionais de saúde. A compreensão do sofrimento naquele que sofre e o atendimento do profissional de saúde a esse mesmo sofrimento é de importância primordial numa medicina humanizada. A mesma motivação, dedicação e empenho investida em encontrar meios para prolongar a vida, deveria ser aplicada na investigação e paliação do sofrimento na doença (Bayés, 2003 ). 
Para Bayés (2004) a comunicação eficaz, assente não apenas na mera informação, mas na escuta e compreensão, explicação e tranquilização dos profissionais de saúde, contribui expressivamente para a diminuição do sofrimento dos doentes. A comunicação consiste em "dar", "tornar conhecido", “compartilhar informação", em suma, "tornar comum”. Quando corretamente exercida pelos profissionais de saúde, Freitas e Sousa (2004), acreditam que fomentam no paciente a capacitação para a utilização de recursos cognitivos, afetivos e comportamentais para enfrentar a doença e tratamentos. O médico, na sua relação médico-doente, é o melhor medicamento, defendeu o médico e psicanalista Michael Balint em toda a sua obra (Balint, 1998).

O excessivo pudor manifestado pela maioria dos profissionais de saúde, especialmente médicos, em disponibilizar informação sobre a doença (diagnóstico e prognóstico), quando, sobretudo, e inscreve no domínio das "más notícias”, poderá ser entendida pela dificuldade destes profissionais em lidar com carácter "contagioso" das emoções despoletadas nos doentes face a essa mesma informação, como ansiedade, medo, impotência (McIntyre, 1995ª). Daí que cada vez mais os profissionais de saúde deleguem a comunicação de "más notícias" em psicólogos, delimitando o seu território a diagnosticar e tratar, e o alívio e tratamento do sofrimento é descartado para os psicólogos, quando estes existem nos serviços, quando tal não acontece, nos profissionais de enfermagem.

Nos cuidados paliativos, a experiência de sofrimento na doença há muito tem vindo a ganhar relevo clínico e científico, talvez justificada pela irreversibilidade e impotência da situação clínica, quando a cura já não é possível, o sofrimento e a dor são o que resta a cuidar e a aliviar, numa palavra, paliar. Não obstante, é imperativo que o sofrimento passe a ser observado, investigado e atendido não somente nos casos terminais, mas em todas as fases do curso da doença, nas quais se encontra igualmente 
presente, e a cura ainda é possível. Mas talvez porque a cura é objetivo, o sofrimento fique tantas vezes descorado.

$\mathrm{O}$ ato de atender ao sofrimento do doente, assiste-se, segundo Benito, Maté e Pascual (2011), numa atitude compreensiva, baseada no respeito pela dignidade da pessoa que sofre. Sublinhando que a avaliação e compreensão deverá basear-se no modelo antropológico, incidindo na visão integrada da pessoa consigo mesma, com os outros e com o transcendente. Trill (2002) numa linha semelhante de pensamento, sublinha que os cuidados aos doentes oncológico deverão ter em conta o sistema de crenças culturais de doença defendidos e partilhados pelos doentes.

Para tal, os profissionais de saúde e os hospitais deverão re-adequar a sua forma de tratar as doenças dos doentes. O primeiro passo, defende Bayés (2004), como Pavlov, prémio Nobel da Medicina e Fisiologia em 1904, partiu d observação para formular hipóteses e definir o plano de investigação para o estudo dos reflexos condicionados, esse mesmo caminho, o da observação, deverá ser seguido para serem implementadas mudanças nos hospitais, no sentido do sofrimento total dos doentes ser atendido, aliviado e compreendido. Esta observação crítica, continua o autor, deverá partir do ponto de vista dos doentes. A observação dos doentes por médicos e outros profissionais de saúde, deverá incidir na sua biografia, palavras, expressões faciais e outras não verbais e em suas demais circunstâncias singulares.

Bayés (1998a) protela "estou convencido que um dos instrumentos metodológicos mais sucintos que se encontra ao nosso alcance para conhecer o que acontece num hospital, a partir do ponto de vista do doente, são as narrativas dos pacientes e familiares que compartilham a sua experiência de doença” (p. 120). Só desta forma, acredita o autor, se conhece a causa do sofrimento do doente, da sua 
perceção de sofrimento, do sofrimento real, tantas vezes invisível aos olhos dos médicos e de outros profissionais, que segregam algumas dimensões do sofrimento, ou então, a visão do sofrimento total do doente. "É necessário escutar o paciente”, já dizia Freud, dar espaço ao doente para verbalizar a sua doença, já defendia Balint (1956/1998). O mesmo pensamento é partilhado por Kubler-Ross (1997/2008). Crente que o poder curativo não se esgota na ciência e nos medicamentos, defende que todos os seres humanos aspiram ao amor, contacto e comunicação, tendo exercido esse gesto curativo ao longo de todo o seu trabalho com doentes terminais.

Neste contexto fazem sentido as palavras da Dra. Rachel Remen (1998) médica e counseller em psico-oncologia,"Só conseguimos enxergar aquilo para o qual desenvolvemos a visão” (p.207). Prosseguindo o raciocínio de Bayés (1998), e integrando o contributo de Remen (1998), desenvolver a visão no sentido de procurar implementar a metodologia da observação do sofrimento dos doentes, na perspetiva dos próprios, é o desfio do século XXI nos cuidados em saúde, em geral, e em oncologia, em particular.

Depois da observação, pois ela conduz à identificação do problema (diagnóstico), segue-se a intervenção. O counselling é uma ferramenta básica a utilizar com pessoas doentes em sofrimento. Que deveria ser utilizada por todos os profissionais de saúde médicos e não médicos, quer com os doentes, quer com as famílias, aliviando assim, o sofrimento de ambos (Bayés, 1998). O sofrimento na doença poderia ser erradicado ou paliado, defende Bayés (2004), se nos hospitais se praticasse mais observação, mais sensibilidade e melhor comunicação.

Quase a terminar este subcapítulo, sublinha-se ainda, que no ato "maior" de aliviar o sofrimento na doença, a medicina se deveria socorrer do conhecimento e 
experiência da antropologia médica. O tema da experiência e do significado da experiência de doença, tem sido objeto de estudo da antropologia médica, nomeadamente, pela antropologia interpretativa. Esta considera a saúde e a doença como o resultado da articulação entre o biológico, o cultural e a experiência subjetiva (Anjos \& Zago, 2006). No processo do adoecer, não se pode separar a pessoa das suas raízes e crenças culturais, elas subjetivam a sua experiência de doença e direcionam a forma não só como a vivem mas como nela agem/intervêm.

Também a intervenção junto do sofrimento em psicologia oncológica deverá socorrer-se dos conhecimentos dessa disciplina de fronteira entre as ciências biomédicas e as ciências sociais e humanas.

O estudo do sofrimento e da dor, segundo Sarró (2009), não é exclusivo da medicina, estando muito para além dela. A eles se encontram referências no pensamento filosófico e religioso de Santo Agostinho, Kierkgaard, Spinoza e Martin Buber. O estudo da dor e do sofrimento pressupõe um equilíbrio entre a antropologia médica e a antropologia religiosa, explica o autor. Contudo, a relação entre sofrimento e religião tem sido erradamente desprezada pela ciência. Saúde e religião sempre andaram lado a lado, como se constata na frase "extra ecclesiam nula salus" (fora da comunidade religiosa não existe saúde). Da mesma forma, o sofrimento não é deixado fora da igreja. Segunda as crenças religiosas de algumas pessoas, a proteção da saúde, aparecimento e cura de doença é mais atribuída a Deus do que à medicina. Para outros, o sofrimento na doença é significado e espelhado com o sofrimento de Jesus Cristo. E nessa significação encontram força para a sua resignação ou superação. A religião oferece a alguns doentes a atribuição de um sentido ao seu sofrimento. No entanto, os médicos não conversam com os doentes sobre as suas crenças religiosas, embora os doentes assim o desejassem (Anadanajah \& Height, 2001). A realidade transcendente na qual se sustentam os 
doentes quando sofrem, não deverá ser desacreditada e desvalorizada pelos profissionais de saúde. Para além de atitude de desrespeito pela pessoa do doente, evocam a maximização da experiência de sofrimento na doença.

Por outro lado, alguns estudos relatam que as crenças religiosas durante os tratamentos, pelo sentimento de esperança que desenvolvem nos doentes, se associam a diminuição de estados depressivos. A maior procura da religiosidade depois do aparecimento da doença, assume, por vezes, o carácter de negociação entre o doente e Deus, no sentido de alcançar a sobrevivência (Aquino \& Zago, 2007). Esta busca não deverá ser entendida como uma fuga à realidade, mas como uma perspetiva de futuro para o sofrimento dos doentes com cancro.

Por último, acrescenta-se a tudo o que já foi dito, a necessidade crescente de formação em psico-oncologia para todos os profissionais de saúde e não apenas para os de saúde mental, defendida por Trill e Holand (1995) e Trill (2002). Uma formação que não se fique apenas pelas experiências didáticas, mas pela sua implementação na prática assistencial aos doentes oncológicos e familiares, assente numa perspetiva multidisciplinar, de aliança e colaboração entre as ciências biomédicas e as ciências sociais e humanas.

Recordando novamente à experiência de Remen (1998), nem sempre o que é mais profissional, é o que mais cura. Relembrando Kubler-Ross (1997/2008), a maior ajuda do médico ao doente é ser sensível, afetuoso e cuidadoso. Exemplo disso são as palavras de um doente de Lobo Antunes (2008): “Doutor: É de olhares. É de olhares que eu preciso. Tudo o que o médico diz sem olhar é bula de medicamento” (p. 45). As interações informais entre profissionais de saúde e os doentes tem impacto profundo no bem-estar psicológico destes (Bennett, 2002), minimizando assim, a experiência de 
sofrimento na doença. Para Almeida e Melo (2002) atender ao sofrimento na doença oncológica deverá materializar-se numa atitude de ser companheiro, fazer o caminho com, agindo em conformidade com a ética profissional e sem descorar a dimensão espiritual, por vezes tão importante nos doentes com cancro. Como refere Sarró (2009), uma coisa é "ver sofrer" outra bem diferente é "sofrer com". Quando o "ver sofrer" se converte em "sofrer com", dá-se o encontro da humanidade com a empatia. Esta deverá ser realidade a dar atenção e significado nos cuidados de saúde perpetrados aos doentes. Quando a responsabilidade ética e profissional de todos os profissionais de saúde se centrar na escuta e no cuidar da(s) perda(s) e do sofrimento dos doentes, caminharemos numa abordagem mais humanizada do ato de cuidar/curar (McIntyre, 2004).

\section{I.3.2.2. Cuidar e aliviar o sofrimento: função da psicologia oncológica}

"Eu dou-me valor, mas para as outras pessoas acho que agora já não tenho o mesmo valor..."

(40 anos, cirurgia conservadora)

Segundo Rojas-May (2006), a psicologia oncológica enquanto sub-especialidade da oncologia, psiquiatria e psicologia deverá centrar-se no paciente enquanto pessoa e não na doença, sempre numa perspetiva biopsicossocial.

A função da psicologia oncológica no alívio do sofrimento consiste em facilitar os meios para que as pessoas possam atingir estados de felicidade na doença, enfrentandoa, ajustando-se e crescendo pessoalmente com a experiência, como alguns estudos indicam. Não obstante, como referido anteriormente, a tarefa de aliviar o sofrimento não é exclusiva da psicologia. Deverá resultar de uma preocupação conjunta de sistema de 
saúde, instituições de saúde, poder governamental, e todos os profissionais de saúde, sem exceção (Bayés, 2009).

Para Liberato e Carvalho (2008) a intervenção psicológica não se deve esgotar apenas no alívio da dor, mas também no alívio do sofrimento que a acompanha. Centrando-se no conceito de dor total, atendendo ao doente como um todo, só assim se trabalha a qualidade de vida. Na doença, o doente sofre o sofrimento na alma e na carne.

Mesmo na prática clínica psico-oncológica, raras vezes se aborda o sofrimento numa perspetiva "despsicopatologizada". Esta tendência poderá ser explicada, por um lado, pela atenção insuficiente que ainda é dada à experiência de sofrimento na doença, e pelas dúvidas existentes acerca da sua definição e mensuração, como também foi dito, por outro.

Juánez, Río-Valle e Peña (2006) numa revisão do conceito através de 30 artigos, verificaram que a definição de sofrimento permanece indiscriminada e conflituosa. $\mathrm{O}$ conceito apareceu associado ao conceito de stresse/distress experimentados de forma duradoura e não foi encontrado nenhum instrumento de avaliação da intensidade do sofrimento. Não obstante, encontraram três métodos de avaliação do conceito, a entrevista clínica (observação do comportamento verbal e não verbal), metodologia qualitativa (modelo interpretativo baseado no significado atribuído à experiência de doença) e quantitativa (desenvolvimento de escalas que medem conceitos relacionados com o sofrimento).

A intervenção da psicologia oncológica na experiência de sofrimento na doença deverá centrar-se na pessoa que sofre na doença com a doença, ou seja, na pessoa do doente. Norteando-se na conceção "pessoa como centro", recordando as palavras de Carl Rogers (1985), a compreensão da pessoa no seu sofrimento na conceção global do 
adoecer humano. Escutando e intervindo nas histórias biográficas da pessoa doente. Respeitando os saberes do doente acerca da sua vida e da sua doença, como coautor da sua doença. Fazer a história do doente e não da doença (Moura, 2008). Ajudar a encontrar um sentido, um significado para o acontecimento doença no ciclo vital.

Esta deverá atender, em primeiro lugar, à conceptualização da doença enquanto acontecimento significativo, que despoleta um conjunto de acontecimentos, igualmente significativos, com repercussões nos hábitos e rotinas, papéis e funções, perspetivas e projetos, face aos quais se procura encontrar um significado na sua trajetória de vida e no ciclo vital e formas de confronto face à nova realidade.

McInteyre $\left(1995^{\mathrm{a}}\right)$ propõem-nos uma abordagem psicológica do sofrimento. Apesar de defender que a abordagem do sofrimento não deverá ser exclusiva da psicologia em geral, nem da psicologia oncológica, em particular, mas sim da responsabilidade de todas as áreas científicas da saúde, inclusivamente da psicologia da saúde, uma vez que pretende investigar e intervir nos aspetos psicológicos da doença, do comportamento do doente e da relação entre médico-doente (McIntyre, 1994). Em todas aa áreas do saber em saúde a abordagem psicológica do doente, segundo a autora, deverá nortear-se pelos seguintes pressupostos: 1). a aceitação da experiência subjetiva de doença do doença, ou seja, a forma como sente, vive, representa e significa a sua doença; 2). centrar-se no doente enquanto pessoa e não na doença, na pessoa doente que dá voz à doença; 3). reconhecer, aceitar e trabalhar os processos de perda, perda da identidade, da integridade, de papéis e estatutos, funcional, relacional, entre outras; 4). respeito e valorização das avaliações pessoais, dos juízos, valores e sistemas de crenças do doente acerca da doença; 5). Atender, avaliar e trabalhar as reações emocionais à doença (medo, tristeza, raiva, desespero, insegurança, entre outras). O trabalho atempado da desregularão emocional decorrente do sofrimento na doença, 
característico do processo de adaptação á situação de doença, previne a evolução para quadros clínicos de distúrbio emocional. 6). compreensão do comportamento de doença, da forma como é exercido o "papel de doente" (McIntyre, 1995').

O counselling, é defendido por diferentes autores, como a técnica de intervenção psicológica mais ajustada, uma vez, que não estamos em presença de sintomatologia psicológica clínica, bem como, as abordagens humanistas, fenomenológicas e existenciais (Bayés, 1998; Gameiro 1999; McIntyre 1999, in prefácio Gameiro, 1999). Sobe este paradigma, a relação de ajuda definida por Carl Rogers (1985), como toda e qualquer relação na qual pelo menos uma das partes promove na outra o crescimento e a transformação pessoal, deverá incidir na veracidade de uma relação estar com, como define a psicologia existencial, estar significativamente na presença de alguém, numa comunicação que vise a procura de um significado comum, na escuta ativa das narrativas das estórias (episódio de um história pessoal) biográficas das doentes com cancro da mama (Guimarães-Lopes, 2006).

Através da escuta psicológica o doente ao falar das suas dores expressa as fontes do seu sofrimento. Juntamente com as queixas corporais dá voz ao sofrimento que o atormenta, "estou com medo, será que esta dor me vai matar?", "esta dor é de morrer”. O psicólogo deverá ser empático com este sofrimento (Sasdelli \& Miranda, 2001). Atendendo à biografia do doentes e à ruptura biográfica que a doença representa no ciclo da vida (Maia, 2009).

Os significados dos doentes sobre a sua doença poderão não ser compatíveis com os significados do médico. Aprofundar o conhecimento acerca das significações de doença é uma tarefa essencial na indicação de intervenções psicológicas relevantes com vista à orientação terapêutica (Aguiar \& Fonte, 2007). As significações pessoais sobre a 
doença influenciam as reações emocionais e a adaptação ao processo de doença. Estas ligam-se a factos mais latos, a significações do doente relativamente a si próprios, sobre a vida, o mundo e o sistema cultural (Reis \& Fradique, 2004).

Nesta ótica, Abdelmalek e Gerárd (1999) defendem que a prestação de cuidados ao doente deveria explorar a relação entre significante-significado acerca do discurso sobre a doença. $\mathrm{O}$ primeiro diz respeito ao sinal ou sintoma, objeto alvo da avaliação/intervenção do médico, o segundo ao sentido atribuído ao primeiro, na representação individual, social e cultural subjetiva, tantas vezes díspares entre medido e doente (Abdelmalek \& Gerárd, 1999). A diversidade do discurso de doença encontra explicação na terminologia tripla da palavra doença na língua inglesa: disease (doença enquanto quadro clínico), illness (a doença como o doente a sente), sickness (o comportamento de doença) (Abdelmalek \& Gerárd, 1999; Joyce-Moniz \& Barros, 2005; Pais-Ribeiro, 2005).

Estudos a partir da análise das narrativas das doentes com cancro da mama, demonstram que as alterações corporais, acompanhadas da afecção da vivência da sexualidade e o comprometimento das funções laborais domésticas, são consequências marcantes da experiência de doença, e causadoras de sofrimento (Aureliano, 2007).

A análise das narrativas constitui um meio privilegiado de exploração das significações de doença, por um lado. Por outro, possibilitam a construção de sentido à experiência, permitindo organizá-la (Aguiar \& Fonte, 2007). A análise narrativa é fundamental na compreensão da identidade das pessoas doentes. Trata-se de uma ferramenta de análise que visa identificar a forma como os doentes dão "voz " aos sofrimentos, bem diferentes da forma como biomedicina os representa. Compreender o paciente como personagem do seu próprio adoecer é essencial na prestação de cuidados 
na doença (Favoreto \& Cabral, 2009). Através da narrativa em diálogo o doente perceciona a sua existência e reconstrói a sua narrativa (Maia, 2009). Resinifica a experiência de doença, clarifica a informação sobre a mesma e ultrapassa as barreiras da estigmatização (Herllich, 2004).

Também em psicologia oncológica, tal como em medicina, a dimensão espiritual não deverá ser descorada. A doença tem a representação pessoal, social e cultural de morte e incapacidade, despoletando no doente o sentimento de desvalorização de si mesmo e de ansiedade e medo perante a morte. Constituindo uma rutura biográfica sofrida (Maia, 2009). Todo o doente oncológico convive com a ideia de morte, mesmo que não a partilhe. Como tal, adquire assim sentido a razão porque muitos doentes encontram força nesta premissa religiosa, pela qual orientam o seu investimento na vida espiritual, para suportar o sofrimento infligido pela experiência de doença. O sofrimento desafia o doente a perspetivar-se numa dimensão mais alargada de significados, a dimensão espiritual e transcendental. Diferentes estudos documentam a importância da espiritualidade e da religiosidade no contexto da saúde/doença, e respetiva interferência no curso da morbilidade e mortalidade (Anadanajah \& Hight, 2001; Giovagnali, Meneses \& Silva, 2006; Koening, 2002; Samano, Goldenstain, Ribeiro, Lewin, Filho, et al., 2004; Steffen, Hinderliter, Blumenthal \& Sherwood, 2001).

Como nos diz Jesse Bering (2011), psicólogo e investigador evolucionista no livro $O$ instinto de acreditar, “ (...) Em momentos de desespero, até o mais sólido ateu pode dar consigo a apelar a Deus” (p. 237). O autor justifica a afirmação com o facto da crença em Deus fazer parte dos nossos processos cognitivos naturais ao longo de séculos. 
Todavia, o estudo da espiritualidade na doença oncológica parece só agora começar a despertar a atenção clínica e a curiosidade científica, em psicologia oncológica e saúde.

A terminar este subcapítulo, acrescenta-se ainda, que o contributo da psicologia da saúde e da psicologia oncológica na abordagem psicológica do sofrimento na doença, não se esgota no trabalho com o doente. Seria especialmente benéfico, em termos da eficiência dos resultados obtidos, bem como, na diminuição dos custos em saúde, se o psicólogo interviesse diretamente na relação profissional de saúde-doente (McIntyre, $1995^{a}$ ). Pois muitas das causas do sofrimento do doente, como já foi anteriormente verificado, resultam do não reconhecimento pelo seu médico do seu sofrer. À semelhança das intervenções psicológicas junto dos doentes, familiares e amigos, intervenções dirigidas aos médicos oncologistas no sentido de desenvolver competências de comunicação/relação eficaz com os doentes, consciencializar para o sofrimento do doente e capacitar para uma forma mais humanizada de lidar com ele, bem como, catalisar e ventilar emoções decorrentes do acompanhamento de alguns doentes, contribuiriam para tratamentos médicos mais eficientes, melhor adesão dos pacientes aos mesmos, diminuição do sofrimento dos doentes e descongestionamento das consultas de psico-oncologia dos centros e institutos de oncologia.

Exemplo deste tipo de formação são os Grupos Balint, fundados por Michael Balint há sensivelmente 60 anos (Salinsky, 2008), dirigidos a médicos de clínica, que na zona Norte de Portugal conhecem uma histórica com mais de 30 anos. A formação em Grupos Balint visa dotar o clínico para a mudança de postura médica, no sentido de dignificar o processo do cuidar. Atribuindo-se especial relevo ao fenómeno da comunicação médico-paciente, no sentido bidirecional original da mesma (GuimarãesLopes \& Santos, 2008). A justificação desta ação formativa incidiu no reconhecimento 
das debilidades relacionais com os doentes manifestas pelos profissionais de medicina, que como vimos, ainda hoje se verificam.

Sustentando-se teoricamente no modelo psicanalítico, a formação oferecida por estes grupos parte da conceção de que o médico é visto pelo doente como "bom" ou "mau objeto". Pretendendo-se assim, ao médico trabalhar suas emoções, por forma a conferir mais qualidade à relação com os doentes, no sentido que ambos saiam beneficiados da mesma (Balint, 1998; Brandt, 2009). Para tal, como explica Antónia Lavinha no $21^{\circ}$ Encontro Nacional de Clínicos Gerais, "o médico não deve ignorar as suas emoções, pelo contrário, deve treinar a gestão das mesmas, tal como um cirurgião treina a sua pericia” (Marques, 2004, p. 58).

Aproveitar a história de efetividade e eficiência dos Grupos Balint com clínicos gerais em Portugal e implementá-la com médicos oncologistas, pode ser perspetivado como um desafio futuro a colocar no ato de aliviar a experiência de sofrimento na doença.

\section{I.3.3. A experiência de sofrimento na doença como oportunidade de crescimento}

"Estive com muitas pessoas em períodos de grande perda e pesar quando um significado insuspeito começou a emergir dos fragmentos de suas vidas. Com o tempo, esse significado revelou-se durável e digno de confiança, até mesmo transformador. É um tipo de força que nunca surge naqueles que negam a sua dor"

(Rachel Naomi Remen, 1998, Histórias que curam, p. 156)

"O mundo muda muito, depois da doença. Dou mais valor à vida do que dava antes. (...) Agora vou todos os anos pelo menos uma vez de férias (...)"

(32 anos, tumorectomizada) 
Como vimos, o sofrimento pode oferecer possibilidade de aprendizagem, crescimento, fortalecimento, enquanto que a dor não. $\mathrm{O}$ crescimento acontece quando é encontrado significado existencial/experiencial para a experiência de sofrimento, na trajetória de vida. A este propósito diz-nos Victor Kranklin (1977/2008) citando Dostoievski em dois pensamentos, no primeiro, o ser humano é o ser a que tudo se habitua, no segundo, "temo somente não ser digno do meu sofrimento". Desta forma, explica o autor, fundador da logoterapia, inerente ao sofrimento há uma conquista interior, a liberdade espiritual do ser humano, que jamais lhe pode ser retirada, permitelhe perspetivar um sentido para a sua vida. Mesmo as experiência mais adversas ou extremas de vida, como as vividas num campo de concentração, as dos doentes em final de vida, entre outras, oferecem a oportunidade de crescimento interior para além de si mesmo. Citando ainda Nietzsch, Frankl sublinha "quem tem por que viver suporta quase qualquer como" (p.129). Como nos diz Guimarães-Lopes (2006), a existência não é alguma coisa que se recebeu, mas que está pessoalmente a ser feita a cada instante no acontecer biográfico.

O sofrimento não deve ser visto apenas no ótica do fenómeno patológico, mas sim, e principalmente no contexto da doença, como frustração existencial. A preocupação, inquietação e desespero da pessoa face à vida e como pode ser vivida é uma angustia existencial, mas não uma doença mental (Frankl, 1977/2008).

Exemplo disso são as borboletas desenhadas pelos judeus nas paredes das camaratas dos campos de concentração, durante a II Guerra Mundial, descritas por Kubler-Ross (1997/2008). Vinte cinco anos depois, a autora interpretou o significado desses desenhos. As borboletas, enquanto símbolo da metamorfose, representavam para os judeus a espera e a crença na transição para um estado de liberdade. 
Os doentes terminais á beira da morte também crescem, quando aceitam a morte, se transcendem e encontram nela um significado na sua vida e existência (KublerRooss, 1969/2008; 1997/2008).

O crescimento no sofrimento é processual. Desenrola-se cumprindo fases, estádios, distintos, cumulativos, estruturados dialeticamente. À semelhança das fases do luto, do luto antecipatório e da aceitação da morte por parte dos terminais, estando o sofrimento presente em todas estas experiências, passa-se por uma fase de negação, isolamento, raiva, negociação e depressão, até se chegar à fase de aceitação/elaboração. Esta última, consolida a experiência de crescimento (Kubler-Ross, 1969/2008).

O cancro enquadra-se na experiência de acontecimentos que Lesser (2009) descreve como "tempos difíceis, aqueles que tememos que nos quebram, ao mesmo tempo aqueles que nos podem abrir e fazer desabrochar, transformando-nos em quem realmente somos" (p. 17). O cancro "quebra", "abre as pessoas ao meio", num duplo sentido, no sentido literal do termo, "abre" o corpo, cortando-o, amputando-o, por força das intervenções cirúrgicas, e dilacera igualmente a alma pela imprevisibilidade e adversidade, mudanças, perdas e limitações da experiência da doença.

Para Bonino (2007) acreditar que na doença a realização e o desenvolvimento pessoal é possível fornece a base o norte para a caminha sofrida na qual o doente tem de se renovar, transformar e reorientar no sentido da sua própria vida. Numa trajetória de descoberta onde o otimismo, a felicidade, serenidade, satisfação e bem-estar são possíveis.

Maria Augusto Amado (2007), doente com cancro da mama mastectomizada, fundadora do Movimento Vencer e Viver em Portugal em 1982, descreve da seguinte forma a sua experiência de sofrimento: "O sofrimento físico, psíquico, oral ou 
espiritual é uma experiência pessoal e única que nos pode destruir ou ajudar a crescer, a fecharmo-nos sobre nós próprios ou abrirmo-nos aos outros, a afastarmo-nos de Deus ou a aproximarmo-nos dele ou até a descobri-lo (...)” (p.165).

Aspetos positivos do sofrimento são descritos por McIntyre (1995 $)$, quando o sofrimento é encarado como desafio e são descobertos possíveis ganhos significativos. A autora destaca o poder criativo do sofrimento, pela possibilidade oferecida de crescimento, na medida que a doença coloca em causa a mortalidade e invulnerabilidade exigindo a reestruturação interna e externa da pessoa, após um período de desestruturação, naquilo que a autora denomina de reconstrução do self. O sofrimento potencia a procura de novos significados face à vida e morte, permitindo revalorizar a vida e a forma como é vivida. Conduz as pessoas a saírem de si mesmas e a voltarem-se para os outros. E por último, promove a transcendência de si mesmo, possibilitando a descoberta e investimento numa dimensão espiritual.

No estudo da versão experimental do Inventário de Experiências Subjetivas de Sofrimento na Doença, McIntyre e Gameiro (1999), utilizando uma amostra de 125 doentes adultos internados em hospitais gerais, relatam que enquanto a perda é uma condição inevitável da doença, as consequências negativas a nível psicossocial não o são. Tendo encontrado aspetos positivos e negativos do sofrimento na amostra estudada.

A experiência de sofrimento para algumas pessoas, em condições específicas, pode conduzir ao crescimento pós-traumático e à perceção de mudança positiva (Krikorian, Limonero \& Maté, 2011). Diferentes estudos, essencialmente de metodologia qualitativa, fazem referência a resignificações positivas da doença e a crescimento pessoal decorrente da experiência de sofrimento na doença (Ching, 
Martinson \& Wong, 2009; Coward, 1990; Rehnsfeld, Lindholm \& Hamrin, 2002; Thomas-Maclean, 2004; Wenzel \& Stevens, 2008).

Rehnsfeld, Lindholm e Hamrin (2002) analisaram 17 entrevistas de mulheres com cancro da mama, constataram que as doentes "focaram" a experiência de sofrimento na doença na existência interior. A experiência foi descrita como "um campo de força" que modificou o ponto de vista sobre si mesmas e seus relacionamentos. Foram igualmente levantadas questões existenciais sobre a vida, a morte e o sentido da vida.

Ching, Martinson e Wong (2009) observaram que os fatores contextuais/culturais influenciam a forma de lidar/enfrentar a experiência de cancro da mama. A interpretação subjetiva positiva do aparecimento da doença promove a aceitação da experiência.

Um estudo com doentes de cancro da mama em estado metastático avançado, consideraram a experiência de doença numa perspetiva transcendente, na medida que através dela se transcendem a si mesmas, quer no sentido de ajudarem outras mulheres, quer no sentido de aceitar as situações imutáveis. O estudo demonstra assim, o encontro do sentido da vida, a partir da experiência de vida em risco, associada à doença (Coward, 1990).

Patrão, Leal e Maroco (2008) verificaram num grupo de 30 mulheres com cancro da mama que a passagem pelo ciclo psico-oncológico (diagnóstico e póstratamentos) foi considerada uma experiência de transição psicossocial, marcada pelo crescimento, pela reestruturação do projeto de vida. O resignificar positivamente da experiência de doença, enquanto experiência transformadora do sentido da vida e da forma de viver, e potenciadora do crescimento pessoal, foi igualmente documentado por 
Remondes-Costa e Pais-Ribeiro (2012) em mulheres que receberam terapia psicooncológica durante os tratamentos.

Pinto, Silva, Moreira e Canavarro (2009) encontraram níveis elevados em todos os índices do Crescimento Pós-Traumático numa amostra de mulheres com cancro da mama, comparativamente com a população em geral, sem trauma e com trauma. Tendo concluído, que a experiência de cancro da mama parece desencadear mais Crescimento pós-Traumático que outros acontecimentos negativos. Mesmo quando o acontecimento doença é vivido como traumático, algumas doentes conseguem crescer com a experiência, tornando-se mais resilientes perante as situações futuras adversas de vida.

Trata-se de um "otimismo trágico", como descreve Frankl (1977/2008), que atendendo ao potencial humano permite: a). transformar o sofrimento em realização humana; b). a oportunidade de se mudar a si mesmo para melhor; 3). A realização de ações responsáveis. Também Carl Rogers (1977-1979/2001) nos fala do poder pessoal, dessa força inerente a todos os organismos vivos e ao ser humano, para sobreviver nas condições mais difíceis e continuar a crescer e a complexificar-se, a tendência atualizante.

Para terminar, e a comprovar a possibilidade de crescimento com o sofrimento decorrente de acontecimentos de vida adversos (doença, luto, perda, guerra, catástrofe, entre outros), são disso exemplo inúmero livros autobiográficos, uns de carácter narrativo, dos quais destacamos mais $O$ ano do pensamento mágico, de Joan Didion (2006), e mais recentemente, Lições de perda, lições de vida de Michele Reiss (2012) e a Última aula de Randy Pausch (2012), professor universitário americano com cancro pancreático em fase terminal, outros em forma de romance, dos quais A Montanha 
Mágica de Thomas Mann (2009), Prémio Nóbel da Literatura em 1929, constitui um clássico.

Como referiu em tempos Marx Weber (citado por Sarró, 2009) pertencer a uma "comunidade de sofrimento" cria laços muito fortes entre os seres humanos. Aí se explica a difusão dos grupos de auto de ajuda, dos movimentos de voluntariado constituídos por doentes, que superada a fase crítica da doença, se dedicam a ajudar outros doentes, as relações de amizade para a vida desenvolvidas nas enfermarias antes e depois da cirurgia, nas salas de espera e de tratamento. Muitas experiências de doença presenteiam os doentes com o enriquecimento e alargamento dos laços sociais. Exemplos de vidas dedicadas a ajudar e aliviar os que sofrem um sofrimento que lhes é familiar, atualizam em si mesmas a resolução da sua experiência e enriquecem o seu desenvolvimento pessoal, existencial e espiritual, conferindo sentido às suas ações e à sua vida.

\section{I.4. Sintomatologia psicopatológica no cancro da mama}

"Perguntar à pessoa sobre o seu nível de angustia é tão importante quanto perguntar sobre o se nível de dor. Se uma pessoa está depressiva ela pode desistir do tratamento ou não encontrar as melhores formas de enfrentar a doença"

(Jimmie Holland, 2011)

(http://veja.abril.com.br/noticias/saude/pensamento positivo-nao-cura cancer)

A presença de alterações/sintomatologia ou transtornos psicológicos em doentes com cancro é frequente e encontra-se bem documentada na literatura nas últimas quatro décadas (Gil, Sirgo, Lunch, Maté \& Estradé, 2001). Em 1983 foi elaborado por 
Derogatis, Marnow, Fetting, et al., o primeiro estudo de morbilidade psicopatológica segundo os critérios do DSM-III (American Psychiatric Association) em doentes oncológicos. Tendo demonstrado que 47\% (101 de 215 dos doentes) evidenciam sintomatologia psicopatológica. A perturbação de adaptação acompanhada de ansiedade e depressão foi as mais diagnosticada (em 68\% dos doentes), seguida da depressão major (em 13\%), a perturbação da personalidade (7\%) e perturbação da ansiedade ( em 4\%). Este estudo foi pioneiro em demarcar a diferenciação entre distúrbio mental primário e distúrbio mental secundário ou decorrente do aparecimento do cancro na trajetória pessoal de vida.

O screening, avaliação e tratamento dos sintomas psicopatológicos revela-se assim essencial na prática clínica diária em oncológica, na medida em que causam sofrimento, interferem na adesão aos tratamentos e na ativação de mecanismos de coping adaptativos na luta contra a doença, e comprometem a qualidade de vida pessoal, familiar, social, existencial e espiritual (Holland, 1998). Baile (2011) e Doolittle e Holland (2011) acrescentam ainda, que o diagnóstico diferencial entre paciente oncológico difícil e transtorno de personalidade é igualmente fundamental, pois prejudica a relação médico-doente e compromete, consequentemente, a adesão terapêutica.

A mama para além da representação cultural, já descrita anteriormente, tem igualmente uma representação psicológica, sexual e afetiva particular para a mulher (Rojas-May, 2007). Por conseguinte, à semelhança do que é suscetível de acontecer noutros casos de cancro, o processo do adoecer do cancro da mama, pode acarretar, comparativamente com outros tipos de cancro na mulher, ainda mais, a ocorrência sintomatologia psicopatológica. 
Neste capítulo procuraremos refletir sobre a relevância das variáveis de personalidade na clínica psicológica e oncológica ao longo da trajetória da doença do cancro da mama. Começaremos por apresentar a relação entre personalidade saúde/doença, seguidamente entre cancro e cancro da mama. Posteriormente será efetuada descrição dos sintomas psicopatológicos mais prevalentes nas doentes com cancro da mama segundo a literatura revisada. A terminar o capítulo serão avançadas propostas terapêuticas individuais, de grupo e alternativas face aos quadros sintomatológicos e psicopatológicos verificados no adoecer da mama.

\section{I.4.1. Personalidade e saúde/doença}

A relação entre personalidade e doença não é um tema novo. $\mathrm{Na}$ antiguidade clássica, período em que os saberes médicos consideravam o corpo e alma como unidade indivisível, na qual o carácter e o temperamento caracterizavam a forma de ser da pessoa e a sua forma de adoecer (Ibáñez, Valiente \& Soriano, 2002). Hipócrates (460-370 A.C) defendia a saúde como estado de harmonia entre as instâncias internas e o meio ambiente. Segundo ele, diferentes tipos de pessoas tinham diferentes doenças. Imortalizou a teoria dos humores corporais (sangue, fleuma, bílis amarela, bílis negra). Consoante a suas quantidades presentes no corpo, conduziam a estados de equilíbrio (eucrasia) ou de doença (discrasia). Séculos mais tarde, Galeno (131-201 d.c.), com base na sua teoria, postulou a existência de quatro temperamentos (tipos de personalidade), correspondentes aos quatro humores de Hipócrates. O temperamento depressivo, "melancólico" (bílis negra), o temperamento otimista, "sanguíneo" (sangue), temperamento irascível, "colérico" (bílis amarela), e o temperamento passivo, "fleumático" (fleuma). A sua teoria dominou o conhecimento científico até ao século XVIII. Com base na mesma, defendeu que mulheres melancólicas tinham maior 
tendência para desenvolver tumores nos seios comparativamente com as mais ativas, bem-dispostas e seguras de si mesmas (Botelho, 2006; Ibánez, Ogden, 2004; Valiente \& Soriano, 2002; Veit \& Carvalho, 2008; Vásquez, Rodrigues \& Álvaréz, 1998).

Mais recentemente, no século XX, primeiro Kretschmer, médico e psiquiatra alemão, desenvolveu um estudo-teoria no qual relacionou a constituição física com o temperamento, propondo o modelo tripartido sobre os tipos morfológicos do temperamento, o tipo Pícnico (correspondente ao temperamento ciclotímico; endomórfico), o tipo Asténico (temperamento esquizotíptico; ectomórfico); tipo Atlético (temperamento misto; mesomórfico) (Botelho, 2006; Patrão \& Leal, 2004b). Posteriomente, Sheldon, com base no trabalho do antecessor, apresenta três tipos de temperamento, o viscerotonina (tolerante, sociável, extrovertido, humor positivo); o somatotonia (corajoso, enérgico, ativo, assertivo, agressivo); o cerebrotonia (artístico, sensível, apreensivo, introvertido, ansioso social (Botelho, 2006).

Ainda no século XX, Freud, considerado por alguns, "biólogo da mente" também deixou alguns legados para esta discussão, os ensaios sobre a histeria são disso exemplo. Não obstante, o marco histórico contemporâneo da relação personalidade saúde/doença deve-se a Alexander e Dunbar nas décadas 40 e 50, ao associarem semelhanças no perfil psicológico de doentes com determinadas doenças físicas, desenvolvendo uma abordagem psicanalítica dos fenómenos psicossomatáticos (Botelho, 2006). Ainda na década de 50, os cardiologistas Mayer Friedman e Ray Rosemman definiram a personalidade Tipo A, como padrão de comportamento associado ao risco de desenvolvimento de patologia coronária, caracterizado por níveis elevados de competitividade, ambição, agressividade, hostilidade e sentido de urgência. Este padrão, segundo os autores, seria o oposto do que identificaram como personalidade Tipo B (Pais-Ribeiro, 2005; Roales-Nieto, Ríos \& Coronado, 2004). 
Posteriormente, foi ainda proposto um terceiro padrão de comportamento, desta vez associado ao risco de desenvolvimento de cancro, o padrão de personalidade Tipo C, do qual falaremos no ponto à frente.

Mais tarde, na década de 60, Eysenck, na obra "The biological basis of personality", postulou a relação entre a personalidade, nomeadamente nos fatores Nuroticismo e Extroversão-Introversão, por si identificados, o funcionamento cerebral e a saúde/doença (Botelho, 2006).

Não devemos esquecer os importantes contributos atrás mencionados na abertura da relação/discussão personalidade saúde/doença. Todavia, também é importante sublinhar que os conceitos de personalidade e temperamento sofreram atualizações ao longo dos tempos até à presente data. A definição mais consensual e generalista de personalidade diz respeito a um conjunto de traços ou características presentes num indivíduo, relativamente constantes no tempo, determinando as suas ações, pensamentos, sentimentos e relações consigo mesmo e com os outros (Carmo, 2007).

Para Milheiro (in prefacio Coimbra de Matos, 2003) da mesma forma que água é constituída por oxigénio e hidrogénio, a sua separação condenaria a sua existência. Também o ser humano não existe se lhe separarem a alma do corpo, o biológico do psicológico, a saúde/doença física da saúde/doença mental. Prosseguindo o mesmo raciocínio, Coimbra de Matos (2003) sublinha que a dissociação corpo-mente é o assassinato da alma, que na sua unidade dá vida a ambos. Opinião concordante é partilhada por Damásio (1995) no livro O erro de Descartes.

Na década de 80 assistiu-se à importante descoberta que o sistema imunológico interage com os outros sistemas, nomeadamente, com o sistema endócrino. Daí resultou uma nova área científica, transversal à medicina, neurologia, psiquiatria e psicologia, a 
psiconeuroimunologia. Campo científico responsável por investigar a relação entre o cérebro, o comportamento e o sistema imunológico, e respetivas implicações para a saúde e doença. A psiconeuroimunologia oferece um importante contributo para o estudo e compreensão de como as emoções e os acontecimentos significativos de vida afetam a saúde. Procurando explicar como os fatores psicossociais, a saber, estados emocionais, stresse, características de personalidade, qualidade das relações sociais, entre outros, interferem no curso saúde/doença (Maia, 2002; Soares \& Alves, 2006). A este respeito, a já mencionada teoria de Selye, sobre a forma como o stresse crónico conduz à exaustão do organismo, interrompendo a homeostase, vulnerabilizando o sistema imunitário, suscetibilizando-o ao aparecimento de doença, permitiu abrir caminho para o estudo desta questão.

O impacto dos acontecimentos de vida na saúde, em função das variáveis psicológicas tem vindo a ser estudado por Maia (2002). Os estudos que analisam a relação entre fatores psicológicos, saúde e sistema imunitário dividem-se em quatro grupos: 1). Os que estudam os efeitos das situações de tresse, em condições naturais e em laboratório; 2). Os que investigam o impacto dos estados de tristeza e de depressão; 3). Os que pesquisam a influência das características de personalidade, e 4). Os avaliam a importância das relações interpessoais. Segundo a autora, o impacto do stresse e dos estados afetivos de tristeza e depressão, encontram sustentabilidade científica na demonstração da imunodepressão, por diminuição da atividade dos linfócitos Natural Killers (NK), e a presença de suporte social encontra correlação significativa com maior atividade das células NK. Sobre a personalidade, os estudos são escassos e inconclusivos. No entanto, a o desânimo e o pessimismo encontra-se relacionado a pior funcionamento imunológico, e as características de personalidade relacionadas com estratégias repressivas para lidar com problemas e emoções associam-se a menor 
eficiência do sistema imunitário. Sujeitos mais inibidos ao nível da expressão emocional e relacionamentos interpessoais apresentam mais problemas de saúde.

O baixo estado de ânimo, níveis elevados de stresse e as estratégias de confronto com a doença não adaptativas em doentes com HIV associam-se a evolução progressiva da doença, e consequentemente, a pior prognóstico (Ulla \& Remor, 2002).

Assim, ao que parece, os gregos estavam certos na ideia, mas errados nos humores. Nas recentes teorias os humores foram substituídos pelas hormonas e neurotransmissores (Botelho, 2006).

A temática da personalidade saúde/doença é transversal a diferentes áreas científicas da psicologia. Cruz (2007) defende que a psicologia positiva representa um contributo atual importante para a compreensão da relação corpo mente, possibilitando a abertura a novas formas de tratamento da doença, bem como, para a promoção da saúde, da felicidade e longevidade. Martin Seligman (2004/2008), fundador da psicologia positiva, no livro "Authentic Happiness" refere um conjunto de estudos responsáveis por avaliar a relação entre a felicidade e o otimismo e a saúde. Os estudos referem que a felicidade que mulheres sorridentes e bem-dispostas tinham maior possibilidade de serem felizes e realizadas no casamento; que as pessoas otimistas têm maior longevidade, comparativamente com as pessimistas; as pessoas felizes têm melhores hábitos de saúde, tensão arterial mais baixa, o sistema imunitário mais forte e suportam melhor a dor, quando estão doentes; dois dos três indicadores do envelhecimento bem sucedido são a saúde física e a alegria de viver.

Em 2001, um estudo realizado por Danner, Snowdon e Friesen baseado na análise de conteúdo das perspetivas futuras de 180 freiras aquando da celebração dos votos, demonstrou que os escritos referentes a emoções positivas (felicidade e 
otimismo), analisados 50 anos depois de serem redigidos, se correlacionam com maior longevidade das freiras.

Outro exemplo da relação entre mente-corpo são os estudos sobre a avaliação das implicações das intervenções psicológicas no sistema imunitário. Os estudos de Pennebaker e colaboradores constituem uma referência clássica neste tipo de trabalhos. Demonstrando que as intervenções psicológicas baseadas na escrita emotiva têm um impacto positivo na saúde física (Pennebaker \& Segal, 1999). Miller e Cohen (2001) numa revisão de 30 artigos, concluíram que todas as intervenções psicológicas, desde a escrita emotiva, relaxamento, até à hipnoterapia têm alguma eficácia no sistema imunitário, mas esta não é cientificamente suficiente.

\section{I.4.1.1. Personalidade e cancro}

A tomada de consciência que a etiologia, o desenvolvimento e a adesão aos tratamentos no cancro se associam a variáveis psicológicas, foi precisamente o que motivou o surgimento da psico-oncologia (Veit \& Carvalho, 2008). Recordando a definição de Holland (1989; 2002), a psico-oncologia, é a subespecialidade da oncologia que estuda a relação entre as variáveis psicológicas e o cancro em duas principais dimensões: (1) o impacto da doença no funcionamento emocional dos doentes, familiares e dos profissionais de saúde que com eles trabalham; (2) o papel das variáveis de personalidade e comportamento na incidência, adesão aos tratamentos e sobrevivência à doença.

Segundo Ibáñez, Valiente e Soriano (2002) a relação entre personalidade e cancro é tão antiga como a história da medicina, e sendo a psico-oncologia filha 
legítima da medicina e da oncologia, possuem um mesmo passado, fazendo este tema parte da história de ambas.

Estudos sobre as relações entre fatores psicológicos e doenças oncológicas são documentados na literatura em duas principais perspetivas: (1) trabalhos que procuram demonstrar como os fatores psicológicos ou caraterísticas de personalidade, nomeadamente, como a incapacidade em lidar com situações geradoras de stresse e a presença de distúrbios emocionais concorrem para o desenvolvimento de cancro. (2) Por outro lado, sendo esta perspetiva reforçada por inúmeros estudos, e com resultados empiricamente melhor sustentados, trabalhos que comprovam o aparecimento de alterações psicológicas nos doentes decorrentes do aparecimento da doença oncológica (Burkberg, Penman \& Holland, 1984; Martinez, 1993). A presença de sintomatologia psicopatológica, nomeadamente de transtornos afetivos, a forma como os doentes lidam com o sofrimento e se ajustam à ao processo de doença, constituem indicadores de como os fatores de personalidade interferem na trajetória da doença oncológica, comprometendo a adesão aos tratamentos, respetiva eficácia e sobrevivência (Derogatis, Abelof \& Melisaratos, 1978; Holland \& Mostravito, 1980).

Os traços de personalidade são assim determinantes na adaptação e confronto com a doença, pois de certa forma, predizem a forma como a pessoa se comporta perante a situação de doença e como responde aos desafios que esta acarreta. Os recursos pessoais para a ajustamento à doença dependem da personalidade, como é o caso do otimismo, da capacidade de resiliência, humor, auto-estima e auto-conceito (Patrão \& Leal, 2004). Como verificou Martínez (1993), doentes com uma atitude e expetativas "negativas" ou "pessimistas" relativamente à doença experimentam mais ansiedade que doentes com atitudes e expetativas "positivas" ou "otimistas", apresentando assim mais dificuldades na capacidade de confrontar eficazmente a 
doença. Por isso, a personalidade, associada ao coping e ao ajustamento à doença, é considerada como variável mediadora entre a doença (variável independente) e a qualidade de vida e sobrevivência dos doentes, na investigação em psico-oncologia (Holland, 2002).

Krantz e Hedges (1987) explicaram a personalidade é impactante na saúde de tês formas: (1) Os traços de personalidade podem constituir um fator etiológico no desenvolvimento de patologia física, mediante a comunicação entre fatores psicoefetivos, atividade, neuroendócrina, sistema imunitário. (2) Os traços de personalidade relacionam-se com a adoção de comportamentos de risco para a saúde. (3) Os estilos de coping face à situação de doença têm correspondência direta com os traços de personalidade, exercendo importante função mediadora na experiência de stresse/doença.

A relação entre fatores psico-efectivos/personalidade e o aparecimento/incidência do cancro continua a ser hipótese não confirmada. O paradigma do perfil de personalidade encontrado num grande número de doentes oncológicos caracterizado por inibição da expressão dos sentimentos agressivos e cólera, negação desses sentimentos, propensão a atitudes de submissão e de adaptação ao meio e tendência depressiva, reúnem ainda bastante controvérsia (Tavares, 1999). Para Andreu (2001), a justificação para tal acontecer deve-se, por um lado, ao fato da psicologia da personalidade ter ficado um pouco à margem dos estudos no âmbito da saúde/doença, o que resulta em pouca literatura sobre o tema. Por outro lado, na opinião da autora, os poucos trabalhos existentes não acompanharam a evolução teórica da psicologia da personalidade. 
A hipótese de existência de padrão de personalidade de risco de desenvolvimento de cancro, denominada de personalidade Tipo $\mathrm{C}$, levantada nas décadas de 70/80, conduta caracterizada pela contenção da expressão de emoções negativas como medo, ansiedade, ira e supressão comportamentos associados, hostilidade, assertividade e dominância, não foi eficazmente corroborada. Segundo Temoshok (1987), tal ficou devido à heterogeneidade e limitação metodológicas das pesquisas realizadas, na sua grande maioria, baseadas em desenhos retrospectivos. A autora defende que o estudo da validez da personalidade Tipo $\mathrm{C}$ em doentes oncológicos só é possível com desenhos de investigação robustos, a designar:

(1) Quase-propectivos - a avaliação psicológica é realizada, num primeiro momento, em sujeitos com desconfiança de possível diagnóstico de cancro. Num segundo momento, é efetuada comparação dos sujeitos que receberam o diagnóstico de cancro com os que não têm a doença;

(2) Propspectivos - a avaliação psicológica é realizada em doentes saudáveis, e estes são seguidos ao longo do tempo até ao momento do diagnóstico de cancro;

(3) Retroprospectivos - combina a recolha dos dados de avaliação psicológica em dois momentos cronológicos destintos, seguimento dos casos recémdiagnosticados, e recolha de informação passada relevante, anterior à história de doença;

(4) Longitudinais - a avaliação psicológica realiza-se ao longo de todas as fases do curso da doença, ou seja, desde o diagnóstico, passando pela reincidência até à morte. 
Perante a vulnerabilidade científica do paradigma do perfil psicológico dos doentes com cancro, preconizado pelo padrão de personalidade/comportamento Tipo C, Temoshok e colaboradores, a partir de meados da década de 80 , propõe um novo modelo, centrado não na relação entre fatores de personalidade e incidência do cancro, mas o papel que esta desempenha nos comportamentos de coping a adoptar face à doença. Passando a testar o modelo dos três tipos de confronto (coping) no ajustamento à doença e tratamentos, o Tipo $\mathrm{A}$, associado aos doentes cardíacos, o Tipo B, o oposto do primeiro, considerado como estratégia adaptativa a situações de stresse, e o Tipo C, relacionado ao risco de desenvolvimento de cancro.

O estilo de coping Tipo A é caraterizado pela expressão intensa das emoções relacionadas com a situação de doença, acompanhada de comportamentos de hostilidade, competitividade, tensão e egocentrismo. O padrão Tipo B, define-se como padrão de comportamento face à doença marcado pela expressão apropriada de emoções com ela relacionada, capacidade de satisfazer as suas necessidades e a dos outros, e relaxado. O confronto Tipo $\mathrm{C}$ assenta na internacionalização/repressão emocional, comportamento de passividade abnegação face à doença. Segundo os autores, consoante a variabilidade da intensidade de cada um destes três estilos de coping, também variável será o impacto sobre a saúde (Fox, Temoshok \& Breher, 1988).

Este modelo obteve melhor aceitação científica que o precedente. A equipa de Tamoshk comprovou em diferentes estudos que o padrão de comportamento Tipo C, enquanto estratégia de coping centrada na repressão emocional do stresse, desamparo e desesperança interagem durante o curso da doença e progressão no cancro (Fox, Temoshok \& Breher, 1988; Temoshok, Hellen, Sagebiel, Blois, Sweet, DiClemente \& Gold, 1985). Quando comparados com os doentes de patologia cardiovascular, os doentes com cancro reprimem mais as suas emoções face à doença, adotando um padrão 
de coping mais do Tipo A, que os doentes cardíacos, estes confrontam a doença de foma Tipo B (Kneier \& Temoshok, 1984).

No que respeita, em particular, à relação entre personalidade e cancro da mama, a literatura desde cedo lhe fez referência. A crença que as variáveis psicológicas prediziam o cancro da mama remontam à antiguidade clássica, já Galeno defendia que as mulheres "melancólicas" eram mais propensas a desenvolver cancro da mama do que as "otimistas". Alguns clínicos e psiquiatras, com base na sua experiência com as doentes, também Sugeriram que as caraterísticas de personalidade e as experiências stressantes de vida podem contribuir para o aparecimento da doença e influenciar o curso do cancro da mama (Greer \& Morris, 1975; Greer \& Morris, 1978). Diferentes estudos empíricos comprovam que a personalidade condiciona a forma como as doentes respondem emocionalmente ao diagnóstico de cancro da mama (Greer, Morris \& Pettingale, 1979).

Começando por nos reportarmos ao papel das variáveis da personalidade na etiologia do cancro, alguns trabalhos relataram a existência de um padrão de comportamento Tipo $\mathrm{C}$ em mulheres com cancro da mama. Um estudo realizado por Greer e Morris (1975) numa amostra com 160 mulheres internadas para realizar biópsia a tumor da mama, às quais foram realizadas entrevistas estruturadas, um dia antes da operação, ou seja, antes da confirmação do diagnóstico. Destas, 69 foram operadas ao cancro da mama e 91 tinham doença benigna da mama, constituindo o grupo controlo. Foram igualmente realizadas entrevistas aos maridos e familiares próximos. Os resultados indicaram associação significativa entre o diagnóstico de cancro da mama e um padrão de comportamento "anormal” ao nível da expressão das emoções, verificável ao longo da vida adulta. A supressão da raiva e de outros sentimentos foi identificada nas pacientes com mais de 40 anos. Conclusões semelhantes foram avançadas por 
outros trabalhos ao nível da supressão da expressão da raiva em doentes com cancro da mama comparativamente aos controlos. Foi igualmente detetada a utilização da negação face à condição de doença (Morris, Greer, Pettingale \& Watson, 1981). Apesar de se revelarem emocionalmente mais inibidas, as mulheres com cancro da mama manifestam-se mais ansiosas e emocionalmente mais perturbadas, quando avaliadas com medidas de autoaplicação que as mulheres saudáveis (Pettingale, Watson \& Greer, 1985). Hilakvi-Clarke, Wright e Lippman (1993) para além de verificarem as dificuldades na expressão de emoções negativas, nomeadamente a raiva, em mulheres com cancro da mama, denotaram também a tendência para evitar conflitos, mesmo quando isso implica o sacrifício das sua próprias necessidades em prol dos outros.

Neme e Bredariolli (2010) num estudo qualitativo baseado em três casos clínicos de cancro da mama e ginecológico, mama, ovário e útero, socorrendo-se na entrevista clínica e avaliação psicológica mediante testes projetivos, os autores encontraram indicadores comportamentais estáveis no tempo de repressão de desejos, necessidades, sentimentos hostis e agressividade; dissimulação da necessidade de afeto; dificuldades na expressão de emoções e sentimentos; empobrecimento afetivo; dificuldade de simbolização; personalidade insegura e dependente (necessidade de aceitação e apoio de terceiros, medo de abandono); dificuldade em lidar com a angustia e ansiedade; fuga de situações conflituosas e dificuldade em superar conflitos. Foram ainda encontrados indicadores de depressão e somatização.

Forner, Hernández, Luch, Garcia-Conde e Ibañez (1986) estudaram a relação entre a personalidade prévia e as crenças das doentes com cancro da mama, comparando as que tinham a doença com mulheres saudáveis. Constataram mais prevalência de ideias denominadas pelos autores de "egoperfectivas defeituosas", caracterizadas pela presença de mecanismos relacionados com a auto-exigência de perfeição, com a 
dependência social, com a responsabilidade sobre si mesma e com a crença em curas mágicas no grupo das doentes da mama.

Em 2004, Patrão e Leal avaliaram a personalidade de uma amostra de mulheres com cancro da mama segundo o modelo big five. Os resultados permitiram traçar um perfil psicológico das doentes caracterizado pelos seguintes traços: calma, resistente, não emotiva, reservada, pragmática, prestável, disponível, simpática, trabalhadora, confiável e organizada. As autoras concluíram que os resultados encontrados corroboram o paradigma da Personalidade Tipo C. As autoras encontraram, relativamente às cinco dimensões do modelo estudado, baixos níveis de neuroticismo, extroversão e abertura à experiência, e altos níveis na amabilidade e conscienciosidade, condizente com o mesmo perfil de personalidade C.

Quanto aos acontecimentos stressantes de vida e respetiva vulnerabilização ao adoecimento de cancro, Priestman, Priestman e Bradshaw (1985) não encontraram diferenças estatisticamente significativas que justificassem a hipótese que o stresse predispõe ao cancro da mama, numa amostra de 200 mulheres (100 com cancro da mama e 100 com patologia mamária benigna), que responderam a um inventário de eventos stressantes nos últimos 3 anos e ao inventário de personalidade de Eysenck. Já para Letho, Ojaner e Kellokumpa-Lehtinen (2005) as situações de stresse podem ser ameaçadoras para as pessoas com personalidade Tipo $\mathrm{C}$, dadas as dificuldades que manifestam em expressar emoções negativas. Por outro lado, a forma como as doentes com cancro da mama são capazes de lidar com o stresse associado à doença influi o curso e evolução da mesma (Hilakivi-Clarke, Rowland, Clarke \& Lippman, 1994).

Ganha assim relevância científica a pesquisa da personalidade relacionada aos estilos de coping no ajustamento ao cancro da mama. Diferentes estudos demonstram 
que os doentes que conseguem exprimir as suas emoções ajustam-se melhor à situação de doença (Classen, Koopman, Angell \& Spigel, 1996; Iwamitsu, Shimoda, Abe, Tani, Kodama \& Okwa, 2003; Watson, Greer, Rowden, Gorman, Robertson, Bliss, et al, 1991). A expressão emocional passa também relacionada a maior sobrevivência neste grupo de doentes (Reynolds, Hulley, Torres, Jacson, Boud \& Cohen, 2000; Watson, Haviland, Greer, Davidson \& Bliss, 1999; Watson, Homewood, Haviland \& Bliss, 2005). O controlo emocional, característico do pedrão de comportamento Tipo C, parece associar-se frequentemente em mulheres com cancro da mama a estratégias de coping fatalismo e impotência, o que agrava a morbilidade psicológica e compromete o ajustamento ao processo de doença (Watson, et al, 1991).

Alguns traços de personalidade reportados a determinadas formas de confronto com a doença começam a ser documentados na literatura. Outros autores referem que os traços de personalidade "pessimismo" e "otimismo" determinam diferentes formas de confronto com a doença. Os primeiros predispõem a reações psicológicas mais adversas face ao diagnóstico e tratamentos. Já os segundos, promovem o bem estar, promovendo uma aceitação mais realista da doença nas doentes da mama. Estes traços de personalidade desempenham ainda um papel importante nas respostas emocionais de ansiedade e depressão decorrentes da situação de doença (Carver, Pozo-Kaderman, Harris, Noriega, Scheider, Robinson, Ketcham, et al., 1993; Carver, et al, 1994). O "pessimismo" parece igualmente predizer a adoção de estilos de coping baseados na "impotência/desesperança" nas doentes com cancro da mama, que por sua vez, predizem respostas de ansiedade e depressão face à doença (Schou, Ekeberg, Ruland, Sandvik \& Kanesen, 2004). Não obstante, num estudo conduzido por Hartl, Engel, Henschbach, Reinelker, Sommer e Friese (2010) o otimismo não foi predizível da qualidade de vida dois anos após a cirurgia. Já valores elevados na escala de 
neuroticismo foram associados a qualidade de vida mais em mulheres com cancro da mama.

O "espírito de luta", segundo Greer, Morris e Pettingale (1979) relaciona-se significativamente com o aumento da sobrevivência em mulheres com cancro da mama. Enquanto que o coping "impotência/desesperança" a menor sobrevivência (Hailand e Bliss, 2005). A personalidade dita assim as estratégias de coping utilizadas na circunstância de doença e na forma como estas, por sua vez, vão determinar a qualidade de vida das mulheres com cancro da mama (Letho et al., 2005).

A personalidade exerce ainda influência na forma como as mulheres com cancro da mama elaboram e representam a experiência de doença. Urcuyo, Boyers, Carver e Antoni (2005) defendem que as doentes com patologia oncológica da mama podem desenvolver experiência positiva perante as consequências adversas da doença e tratamentos. Num estudo por eles elaborado, ficou demonstrado que a experiência positiva da doença é mediada pelas características de personalidade responsáveis pelas estratégias de coping centradas na reformulação positiva e na crença religiosa.

A hipótese de personalidade Tipo $\mathrm{C}$, definida como perfil de personalidade associado aos doentes com cancro continua a carecer de confirmação, já a hipótese da personalidade determinar as estratégias de coping no ajustamento ao processo de doença, parece ter conquistado efetividade e relevância científica, enquanto variável mediadora na trajetória de doença e sobrevivência.

Apesar dos conceitos de cancro, doença, carácter, temperamento e personalidade terem sofridos alterações desde a época grega até aos dias de hoje, a discussão mantémse até à atualidade (Tavares, 1999). Apesar da controvérsia existente na relação entre personalidade e saúde, mais concretamente, no que respeita ao possível papel enquanto 
fator desencadeante da doença, face à inconsistência dos resultados documentados. $\mathrm{O}$ estudo dos efeitos da personalidade na carcinogénese, recidiva e sobrevivência nos doentes oncológicos seria pertinente de continuar a ser estudado, no sentido de se perceber concretamente quais as variáveis de personalidade suscetíveis de concorrer ou predizer a vulnerabilidade ao desenvolvimento de doença oncológica e respetiva recidiva, bem como, quais as que potenciam o aumento da sobrevivência (Hartl et al., 2010). Desta forma, poderiam ser pensadas medidas de intervenção psicológicas de carácter preventivo do aparecimento da doença, incidindo nas variáveis psicológicas de risco, e de promoção da qualidade de vida na doença, quando esta já se encontra instalada. Em ambos os casos o apoio psicológico e psicoterapia teriam aqui um papel relevante. E os ganhos em saúde trariam benefícios para a ciência, para a psicologia, psicologia da saúde e oncológica, para os serviços de saúde em geral, bem como, para todas as áreas profissionais que trabalham em oncologia, e para os doentes e familiares, em particular.

Daí a pertinência da continuidade do seu estudo, recorrendo a desenhos natureza prospetiva e longitudinal que testem o papel psicoprofilático da personalidade em contextos de saúde/doença (Botelho, 2006). Pois como vimos, nomeadamente o tema personalidade Tipo $\mathrm{C}$ e doença oncológica deixou de ser estudado no final da década de 80, quando outros trabalhos deitaram a relação por terra, indicando novas direções à investigação empírica no contexto da psicologia da saúde e oncológica a partir dos anos 90, onde designadamente, variáveis como o coping e a qualidade de vida passam a assumir relevância científica e clínica.

A concluir este ponto e fazendo ponte de ligação com o seguinte, segundo Rojas-May (2007), a estrutura psicológica e a personalidade do doente, bem como, a pré-existência de psicopatologia anterior ao aparecimento da doença, as expectativas 
relativamente ao curso da doença, juntamente com variáveis relacionadas com a história da doença individual e familiar, o apoio social e a informação e conhecimentos sobre a doença, vão determinar a resposta emocional ao processo de doença, e sobre esses efeitos não parecem restar dúvidas.

\section{I.4.2. Sintomas Psicopatológicos decorrentes do cancro da mama}

"Aquilo a que costumamos chamar Saúde Mental não é apenas uma função psicológica. (...) Em minha opinião trata-se de algo mais profundo e mais global. (...)

Elo que conjuntura o sujeito e participa em todo o funcionamento, quer no seu lado psicológico quer no seu biológico".

(António Coimbra de Matos, 2003, p.11)

"Desde que fiquei doente sinto que o meu psicológico não está bem .... O meu lado psicológico não está equilibrado ... tenho um filho e ás vezes fico sem paciência ... nunca me disseram nada ... mas penso que seria bom eu ser ajudada”.

(32 anos, tumorectomia)

A doença é um acontecimento adverso de vida, representado um rutura no acontecer biográfico, acarretando múltiplas mudanças a nível biológico, psicológico, social e espiritual. Como todo e qualquer acontecimento disruptivo, exige adaptação, para tal é necessário reorganização intrapsíquica. Se é bem verdade que algumas mulheres o conseguem fazer com o apoio da família e dos amigos, ainda que em algumas fases do curso da doença tenham experienciado sentimentos de ansiedade, stresse, depressão, irritabilidade, entre outros. Para outras, estes sentimentos acompanham-nas recorrentemente, impossibilitando ou surgindo por consequência da 
impossibilidade de adaptação à situação de doença, adquirindo relevância clínica de intervenção.

Desde sensivelmente, meados do século passado, adquiriu visibilidade na prática clínica que fatores psicológicos comprometem a eficácia e adesão aos tratamentos oncológicos, constatação que motivou a emergência da psico-oncologia, comprometendo a qualidade de vida de doentes e familiares em todo o processo de doença (Veit \& Carvalho, 2008). Em algum momento da trajetória de doença, cerca de $30 \%$ dos doentes oncológicos apresentam sintomas psicopatológicos (Vasquez, Rodrigues \& Álvarez, 1998). A depressão e ansiedade são as perturbações psicológicas mais frequentes (Tavares, 1999). Aproximadamente 20\% dos doentes podem apresentar depressão grave, ansiedade, luto, fúria, falta de controlo e mudanças de personalidade (Ogden, 2004). Gonçalves (2011) refere a existência de doença depressiva tratável em cerca de $25 \%$ dos doentes com cancro avançado e de 3,7 a 58\% em doentes paliativos.

No cancro da mama, as percentagens são concordantes. Graner, Cezar e Teng (2008) fazem referência a vários trabalhos, num encontraram prevalência de depressão e ansiedade de $33 \%$ no momento do diagnóstico e $15 \%$ após um ano, em mulheres com cancro da mama. Noutro encontraram 50\% de depressão em mulheres mastectomizadas e $50 \%$ em tumorectomizadas. Num terceiro, detetaram $32 \%$ de transtorno afetivo em mulheres que aguardavam cirurgia e e $24 \%$ em mulheres na fase inicial da doença (aquando da realização de biopsia). Patrão e Leal (2004) referem que os transtornos decorrentes da resposta emocional ao cancro da mama, segundo o DSM-IV, são a perturbação de ajustamento, com depressão e/ou ansiedade, ou misto. São ainda identificados em doentes com cancro da mama, e por esse motivo objeto de encaminhamento para apoio psicológico, ideação suicida, fobia, ataques de pânico, depressão major, delírio e distúrbios da personalidade (Faria \& Xarepe, 2000). 
Num estudo realizado em Portugal por Amaral e Moreira (2009) não foram encontradas diferenças significativas ao nível da ansiedade, depressão e qualidade de vida, em mulheres recentemente diagnosticadas com cancro da mama, encontraram sim, níveis mais elevados de ansiedade nas mulheres com possibilidade de diagnóstico, justificável perante a situação de incerteza. Estes resultados poderão ser explicados pela melhoria da comunicação médico-doente oncológico, centrada no esclarecimento de dúvidas e incertezas relativamente aos tratamentos e prognóstico; pela mudança na perceção do cancro da mama, passando a reconhecer-se como doença possivelmente curável, e por fim, pelo sucesso das intervenções psicológicas, que vão sendo cada vez mais frequentes.

Fazer o diagnóstico diferencial entre a presença transitória de alterações de humor (tristeza, depressão), ansiedade, stresse e dificuldade de ajustamento, enquanto reações emocionais naturais/existenciais em determinados episódios do curso da doença (diagnóstico, proximidade do início dos tratamentos, espera dos resultados de novos exames), da presença de sintomatologia psicopatológica avaliada clinicamente, é condição impreterível.

Neste capítulo apresentamos revisão da literatura sobre os quadros sintomatológicos mais prevalentes no cancro da mama, tendo em conta as variáveis que pretendemos estudar. Começamos por referir alguns estudos relativamente à resposta emocional de stresse em mulheres com cancro da mama, ansiedade, depressão, descritos na literatura como mais prevalentes na população que pretendemos estudar. 


\section{I.4.2.1. Stresse}

\section{I.4.2.1.1. Definição}

A palavra stress deriva etimologicamente do verbo latino stringo, stringere, strinxi, strinctum, que significa apertar, comprimir, restringir (Serra, 2002). O termo stress foi introduzido pelo fisiólogo Walter Cannon (1932) no campo da Saúde, no entanto, deve-se a Hans Selye a sua difusão (Vázquez, Rodríguez \& Álvarez, 2003). Originário do campo da engenharia, já no século XIV o termo se encontrava associado à conotação de dificuldade ou adversidade; no século XVII, a juntar aos dois anteriores, empregava-se para designar exigência e aflição; nos séculos XVIII e XIX, exprimia força, pressão, esforço exercido sobre objetos ou pessoas (Pais-Ribeiro, 2005). À semelhança do que sucedeu com outras palavras, stress foi adaptado para Português, passando a designar-se stresse.

Cannon começou por utilizar o termo stresse em experiências de reação face a situações de luta ou fuga, observando as reações do sistema adrenérgico e simpático em humanos e animais em contexto de laboratório, quando expostos os condições adversas como frio, falta de oxigénio, entre outras, induzindo uma experiência stressante. Sendo pioneiro na associação do stresse com o desequilíbrio homeostático (Pais-Ribeiro, 2005). Selye, reforçando a ideia do seu antecessor, defende que o stresse é um processo inerente à própria vida. Sublinhando que a ausência dele conduziria os organismos à sua morte. $\mathrm{O}$ autor procedeu à subdivisão do conceito, definindo como stresse positivo ou "bom stress" (eustress), o que visa uma resposta adaptativa dos organismo ao meio, essencial à sobrevivência, e como stresse negativo ou "mau stress" (distress), aquele que dada a sua força insuportável pode provocar danos no organismo. Este processo foi descrito por Selye como Síndrome Geral da Adaptação, constituído por três fases. A 
fase inicial, denominada de "alarme", descreve o aumento da atividade fisiológica imediata à exposição de situação stressante. A segunda, designada de "resistência", dá conta da tentativa de resistência face ao mesmo, envolve o coping. A terceira e última, apelidada de "exaustão", sucede após situação continuada de exposição ao agente stressor, sem que a resistência tenha sido bem sucedida (Ogden, 2004 ${ }^{\mathrm{a}}$ ).

Nas atuais definições de stresse, considera-se stressor o fator causal associado ao ambiente externo (por exemplo, problemas laborais), e como stresse a resposta ao agente stressor, sendo a mesma, acompanhada de alterações bioquímicas, fisiológicas, psicológicas e comportamentais $\left(\right.$ Ogden, $\left.2004^{\mathrm{a}}\right)$. Seguindo essa linha de pensamento, e afastando-se dos modelos de Cannon e Selye, focalizados nas mudanças fisiológicas, passou-se igualmente a estudar o stresse associado aos acontecimentos de vida, ou seja, determinados acontecimentos de vida no ciclo vital da pessoa são suscetíveis de desencadear stresse (Ogden,2004 $)$.

$\mathrm{Na}$ década de 70, Lazarus e Cohen, introduzem o estudo da compreensão da resposta de stresse no campo da Psicologia. Neste contexto, a atenção centrou-se no papel da avaliação, por parte do sujeito, do acontecimento potencialmente stressante, desencadeando assim a resposta de stresse. Na década de 80, Lazarus e Folkman, enfatizam a importância do auto-controlo na mediação do stresse, associando-lhe os termos auto-eficácia, robustez (hardiness) e domínio, para justificar uma resposta efetiva e eficaz ao stress (Ogden, 2004 ${ }^{\mathrm{a}}$. Lançando as bases para o paradigma de estudo do stresse no âmbito da Psicologia da Saúde.

O stresse é um tema transversal a vários contextos, sendo objeto de estudo de várias ciências e disciplinas científicas, desde as Biológicas, passando pelas Biomédicas, até às Sociais e Humanas. Como refere Serra (2002), na sua obra “Stresss 
na Vida de Todos os Dias", o stresse faz parte do quotidiano do ser humano, podendo ser desencadeado por determinantes internas ou externas, agradáveis ou desagradáveis. Não obstante, não deverá ser reduzido a situação meramente incomodativa.

A exposição continuada à experiência de stresse, afeta o bem-estar, a saúde física e mental. Já em situações pontuais, segundo o autor, o stresse tem uma componente pró-ativa, conduz a pessoa à resolução de problemas, ao desenvolvimento de potencialidades e melhoria da adaptabilidade. As circunstâncias indutoras de stresse podem ser de natureza biológica, psicológica e social.

A nível Psicossocial, Serra (2002) salienta como acontecimentos indutores de stress: os acontecimentos traumáticos (acidentes de viação, catástrofes naturais), os acontecimentos significativos de vida (morte de ente querido, divórcio, perda do emprego), situações crónicas (problemas associados ao desempenho de papéis no dia a dia), acontecimentos desejados não ocorridos (desejo de engravidar, conseguir emprego) traumatismos do desenvolvimento (negligência, abuso sexual). As repercussões dos acontecimentos stressantes é influenciada pela forma como a pessoa perceciona, avalia, atribui significado e pela forma como é apoiado, conclui o autor.

O Stresse é abordado em três perspetivas diferentes, a Ambiental, a Psicológica e a biológica, que apesar de diferentes se integram entre si. A perspetiva Ambiental centra-se na avaliação de acontecimentos ou experiências associados a exigências adaptativas; a Psicológica, na avaliação das capacidades individuais de resposta às exigências face a determinadas experiências ou acontecimentos; a biológica centra-se na avaliação da ativação dos sistemas fisiológicos despoletada por condições físicas e psicológicas (Soares \& Alves, 2006). 


\section{I.4.2.1.2. Diferenciação entre Stresse e Ansiedade}

É conveniente distinguir Stresse e ansiedade, pois embora apareçam frequentemente relacionados, não são necessariamente a mesma coisa. Segundo Vázquez, Rodríguez e Álvarez (2003), verificam-se algumas alterações fisiológicas idênticas quando um organismo experimenta ansiedade e stresse, como por exemplo a pressão arterial, frequência cardíaca, etc. A sua distinção assenta na função de um e outro. Enquanto o stresse é uma resposta do organismo a uma exigência real do meio, a ansiedade é uma alteração psicofisiológica que se experimenta perante a antecipação de determinada situação, sendo esta mais ou menos provável. Reportando-nos à situação de doença oncológica, a experiência de adoecer é vivenciada como um acontecimento stressante, e o tempo de espera que antecede a realização de exames, conhecimento de resultados e tratamentos, se faz acompanhar de experiência de ansiedade. Talvez esta destrinça, tenha servido de reflexão para a recente conceptualização da experiência de doença oncológica enquanto acontecimento de vida stressante pós-traumático.

\section{I.4.2.1.3. Stresse e cancro da mama}

Segundo Vaz Serra (1991), a doença é um acontecimento no ciclo da vida gerador de stresse, ou melhor, de distress. Seguindo a mesma linha de pensamento, Ogden $\left(2004^{\mathrm{b}}\right)$ defende que o diagnóstico de cancro é dos acontecimentos mais stressantes da vida de qualquer pessoa.

A relação entre stresse e cancro há muito que é objeto de profunda investigação, abundando na literatura as referências ao tema. Em maior número e reunindo maior consenso, literatura que estuda o stresse como variável dependente do cancro, em menor número e suscitando inúmeras convergências, literatura relacionada com o estudo do 
stresse enquanto variável independente. Neste ponto, apenas nos vamos reportar a literatura sobre stresse desencadeado pela experiência de doença.

A doença, enquanto acontecimento stressor, pode afetar o comportamento do doente na sua relação com a doença, interferindo na procura de ajuda, adesão aos tratamentos e recomendações médicas e adoção de estilos de vida saudáveis (Ogden, $\left.2004^{a}\right)$

Encontramos referências na literatura sobre a existência de níveis elevados de distress, previamente à realização de quimioterapia. Estudos evidenciam que a capacidade de gestão do stresse se associa a níveis baixos de ansiedade e depressão e melhor qualidade de vida mental (Faul, Heather, Williams, Loftus \& Jacobsen, 2009).

A intensidade do stresse, despoletado pela experiência de cancro da mama é diferente nas diferentes fases do curso da doença. Importa caracterizar sucintamente as fases deste ciclo. Pinto e Pais-Ribeiro (2007) descrevem três fases da experiencia oncológica: $1^{\text {a }}$. Fase aguda, inicia-se com o diagnóstico e culmina com o fim dos tratamentos; $2^{\mathrm{a}}$. Fase intermédia, inicia após o fim dos tratamentos e prolonga-se até à confirmação da remissão da doença; $3^{\text {a }}$. Fase permanente, corresponde ao tempo de vida após a sobrevivência ao cancro. Comecemos por analisar a experiência de stresse na fase inicial ou aguda do processo de doença.

A literatura é consistente em demonstrar que a fase inicial da doença parece constituir o período de maior crise, pois o corpo e o futuro são sentidos como ameaçados, podendo surgir sentimentos antecipatórios de perda, acompanhados de tristeza, raiva, culpa e desespero. Segundo Holland e Mastrovito (1980), o stresse na doença oncológica da mama caracteriza-se pela presença associada de ansiedade, depressão ou ambas e ocorre em quatro principais momentos do percurso da doença: 1). 
Stresse pré-operatório; 2). Stresse pós-operatório; 2). Stresse durante os tratamentos; 4). Stresse na recorrência da doença.

Frequentemente são encontrados níveis clinicamente significativos de ansiedade em mulheres recentemente diagnosticadas com cancro da mama, comprometendo assim, a faceta geral da qualidade de vida, em particular, o domínio físico (Moreira, Silva \& Canavarro, 2008).

Gouveia e Tapadinhas (2008), num estudo comparativo entre mulheres com cancro da mama e mulheres sem doença da mama, encontraram altos níveis de distress psicológico e níveis elevados de sintomatologia depressiva e ansiosa nas mulheres com cancro da mama, durante o processo de doença. Também Rebelo, Vicente, Gomes \& Moisão (2008) verificaram a prevalência de ansiedade nas fases pré e pós-cirurgia e nos tratamentos nas doentes mastectomizadas e nas que realizaram cirurgia conservadora da mama.

Pereira, Pereira e Rodrigues (2009), num estudo qualitativo subordinado à análise de conteúdo de quatro entrevistas semiestruturadas a mulheres com cancro da mama, foi possível constatar que o cancro da mama é relatado como um acontecimento stressante, que obriga à elaboração de um conjunto de emoções e mobilização de recursos para a sua superação, sendo o apoio social referido pelas doentes como fundamental.

Antoni, Lechner, Diaz, Vargas, Holley, Phillips et al. (2009), num estudo experimental, recolheram amostras de sangue de mulheres com cancro da mama nos estádios 1-3 da doença, submetidas a cirurgia à 4-8 semanas, e encontraram níveis elevados de ansiedade e de cortisol (hormona do stresse). Viram os níveis de cortisol reduzir após intervenção cognitiva de grupo de gestão de stresse, com a duração de 10 
semanas. Os autores concluíram que a presença de cortisol, como hormona indicadora da presença de stresse, enfraquece a resistência do sistema imunitário, comprometendo assim, o tratamento da doença e aumentando o risco da reincidência. O cortisol tem vindo a ser crescentemente considerado uma variável importante em Psicologia da Saúde. Pelo facto da sua produção e segregação aumentar em quantidades crescentes, durante a após a exposição a agente stressor, afetando a função imunossupressora do sistema imunitário (Soares \& Alves, 2006).

Outros trabalhos defendem que o sentimento de incerteza prevalente no final dos tratamentos, enquanto é aguardada a confirmação de transição de paciente oncológico a sobrevivente, é responsável por aumentar os níveis de stresse, afetando a qualidade de vida dos pacientes oncológicos durante este período (Garafalo, Choppala, Hamman \& Gjender, 2009).

\section{I.4.2.2. Ansiedade}

\section{I.4.2.2.1.Definição}

É conveniente distinguir, em primeiro lugar, ansiedade, enquanto conceito, de transtorno de ansiedade. Segundo a Enciclopédia Larousse (1997) ansiedade vem do latim anxietas, que significa inquietude associada à incerteza de uma situação; apreensão sobre um acontecimento; agitação impaciente; desejo impaciente, impaciente por alguma coisa. O Dicionário de Psicologia (2001) define-a como uma emoção gerada pela antecipação de um perigo vago, de difícil previsão e controlo, transforma-se em medo na presença de um perigo identificado. Trata-se, por assim dizer, de um estado psicológico caracterizado por sentimentos de tensão, apreensão, nervosismo, preocupação, perante a perceção de ameaça de uma situação ou acontecimento, 
acompanhada de ativação do sistema nervoso autónomo (alteração do ritmo cardíaco, respiratório, suores, secura de boca, náuseas, vertigens, entre outros). No entanto, recordamos que não deverá ser confundida com stresse, oportunamente diferenciado no ponto anterior.

A ansiedade acompanha-nos ao logo da vida, é por isso existencial ao ser humano. Invade-nos antes da tomada de uma decisão, como explica Guimarães Lopes (2006), nos momentos que antecedem algo desejado, comunicado ou anunciado. Ainda segundo o mesmo autor (1996), é necessário distinguir ansiedade de angustia. A primeira deriva na etimologia latina de “anxius" (movimento, inquietação, agitação), já a segunda de "ango" (sufoco, aperto, inibição). Os conceitos variam numa dupla polarização do fenómeno, o polo de atividade presente na ansiedade, e o polo da passividade característico da angustia. Bem distinta de transtorno/perturbação de ansiedade. A diferença entre a experiência "num estado normal" de sentimentos, emoções, sinais e sintomas da apresentação psicopatológica dos mesmos, consiste, tal como diz Bergeret (1997), na capacidade de adaptação à situação que os desencadeia. Os sintomas psicopatológicos, como descreve Scharfetter (1997) “ são modos de vivência e de comportamento, reconhecíveis como iguais ou similares, e que se destacam do quotidiano próprio das pessoas de uma determinada cultura” (p.23).

A ansiedade pode apresentar-se de duas formas, estado (situação atual afetiva), traço (forma habitual da pessoa reagir). A primeira, é referente a um estado mental no tempo presente, a segunda, é uma característica da personalidade (Vallejo, 1999). Inicialmente denominados de transtornos/perturbações de angustia, a partir do DSM-IV (American Psychiatric Association: Manual de Diagnóstico e estatística das perturbações mentais) alterou-se a designação para transtornos/perturbações da ansiedade. Segundo este manual de diagnóstico, fazem parte deste grupo os ataques de 
pânico, a agorafobia, perturbação de pânico com e sem agorafobia, agorafobia sem história de perturbação de pânico, fobia específica, fobia social, perturbação obsessivocompulsiva, perturbação de stresse pós-traumático, perturbação aguda de stresse, perturbação de ansiedade generalizada, perturbação da ansiedade provocada por um estado físico geral, perturbação de ansiedade induzida por substancias, perturbação de ansiedade sem outra especificação (American Psychiatric Association, 1996).

Na CID-10 (Organização Mundial de Saúde / World Health Organization: Classificação de transtornos mentais e do comportamento, 1998) os transtornos de ansiedade agrupam-se nos transtornos neuróticos, relacionados ao stresse e somatoformes. Acrescentando ao DSM-IV o transtorno misto ansioso-depressivo, o transtorno misto de ansiedade, outros transtornos de ansiedade, reações ao stresse grave e transtornos de adaptação e transtornos dissociativos.

A ansiedade generalizada e as perturbações de adaptação são as mais frequentes nos doentes com cancro. No transtorno de ansiedade, a). a tensão, preocupação e apreensão deverão permanecer por um período de pelo menos seis meses; b). a pessoa tem dificuldade em controlar a preocupação; C). a ansiedade e a preocupação estão associados a pelo menos três dos seguintes sintomas: 1). Agitação, nervosismo ou tensão interior; 2). Fadiga; 3). Dificuldade de concentração ou esquecimento; 4).irritabilidade; 5). Tensão muscular; 6). Perturbações do sono (dificuldade em adormecer ou permanecer a dormir, ou sono agitado). $\mathrm{O}$ estado de ansiedade causa malestar clinicamente significativo ou deficiência no funcionamento social, ocupacional ou outro.

A CID-10 (1998) acrescenta :1). Sintomas de excitação autonómica: palpitações, aumento da frequência cardíaca; sudorese; tremor ou estremecimento; boca seca; 2). 
Sintomas no tórax e abdómen: dificuldade em respirar, sensação de sufocação, dor ou desconforto torácico, náusea ou desconforto abdominal; 3). Sintomas envolvendo o estado mental: sentimentos de atordoação, desequilíbrio, desfalecimento; sentir que os objetos são irreais (desrealização) ou que o "eu” está distante (despersonalização), medo de perder o controlo, ficar louco ou desmaiar; medo de morrer; 4). Sintomas gerais: ondas de calor ou calafrios, sensação de entorpecimento ou formigueiro; 5). Sintomas de tensão: sentir-se "nervoso", "no limite" ou mentalmente tenso, sensação de nó na garganta ou dificuldade em engolir; 6). Outros sintomas: resposta exagerada a surpresas menores ou estar sobressaltado.

A perturbação da adaptação, segundo o DSM-IV (1996), caracteriza-se pela presença de sintomas emocionais e comportamentais em reação ao/s fator/es de stresse, identificados três meses após a ocorrência do mesmo. Os sintomas são clinicamente significativos manifestando-se sob as seguintes características: 1). Sintomas exagerados face à reação normal e previsível determinada pelo fator de stresse; 2). Disfunção significativa nas áreas sociais ou ocupacionais, ou outras. Os sintomas não se enquadram numa situação de luto. E terminada a situação de stresse, os sintomas não persistem por um período superior a seis meses. A CID-10 (1998) acrescenta que o transtorno de ajustamento poderá fazer-se acompanhar de reação depressiva leve; de reação progressiva prolongada; reação mista de ansiedade e depressão, com perturbação predominante de outras emoções; com perturbação predominante da conduta; com perturbação mista de emoção e conduta; com outros sintomas predominantes específicos. 


\section{I.4.2.2.2. Distúrbio de ansiedade e cancro da mama}

A ansiedade acompanha o doente na sua jornada de doença. Desde o pré diagnóstico, passando pelo diagnóstico, até ao tratamento, continuando pela recorrência e progressão da doença e fase terminal/paliativa. Surge associada a sentimentos de preocupação, incerteza, angustia e medo relativos ao diagnóstico e prognóstico (Carvalho, 2008, Pereira, 2008). Quando é intensa e duradora, a ansiedade pode dificultar a capacidade de compreensão da doença e dos seus tratamentos, condicionando a adesão aos procedimentos terapêuticos, comprometendo o diagnóstico. A ansiedade é igualmente responsável pela diminuição da qualidade de vida durante a trajectória da doença, na medida que causa muito sofrimento emocional à pessoa doente. Por outro lado, interfere com a eficácia de alguns medicamentos, como é o caso dos antieméticos (alívio das náuseas e vómitos decorrentes da quimioterapia) (Carvalho, 2008). Ações muito simples levadas a cabo pelos profissionais de saúde podem prevenir ou diminuir a reação ansiosa nos doentes. A informação adequada acerca do diagnóstico, tratamento e prognóstico é a mais vantajosa, simples e económica (Carvalho, 2008; Pereira, 2008). A comunicação profissional de saúde-doente desempenha também um papel primordial. Habilidades neste domínio, satisfação com a relação com os profissionais de saúde e com o apoio por estes fornecido, alivia a ansiedade dos doentes oncológicos. A inabilidade na transmissão de más notícias é responsável por aumentar significativamente os níveis de ansiedade dos doentes (Liénard, Merckaert, Libert, Delvalux, Marchal, Boniver et al., 2006). Assim, a comunicação tem um importante papel no alívio da ansiedade na prevenção da sua evolução para níveis clínicos (Stark \& House, 2000).

Perante as razões já evocadas, é natural que os doentes com cancro experimentem ansiedade durante o curso da doença. Há momentos particulares ao longo 
da trajetória de doença responsáveis por fazer despoletar picos de ansiedade, enquanto é aguarda a confirmação do diagnóstico, antes da realização dos tratamentos (cirúrgicos, quimioterapeuticos, radiológicos, entre outros), antes e durante a hospitalização, e a proximidade de realização dos exames de follow up (Pereira, 2008). Não obstante, deverá distinguir-se a ansiedade situacional ou episódica ("normal”) da ansiedade Clínica (patológica) (Stark \& House, 2000). Esta última apresenta-se de forma recorrente durante a maior do dia há pelo menos mais de duas semanas, fazendo-se acompanhar de outros sintomas: humor ansioso, irritação, desprazer generalizado, pensamento intrusivos, incapacidade em relaxar, impaciência, necessidade de ajuda imediata, podem ocorrer ataques de pânico. Sintomas de ansiedade natureza autonómica, mediados pelo sistema simpático, se acrescentam, completando o quadro: taquicardia, sudorese, dor ou pressão no estômago, dificuldades respiratórias, sensação de pressão no peito, tonturas e parestesias. Sintomas de ordem parassimpáticas também podem ser observados: tensão abdominal, náuseas, diarreia. Uma vez mais, e sempre, é aconselhável o diagnóstico diferencial entre sintomatologia psicológica e sintomatologia física decorrente dos efeitos colaterais dos tratamentos (Carvalho, 2008).

Contudo, a ansiedade quase sempre se acompanha de outros transtornos, como depressão, estados mistos e perturbação da adaptação (Carvalho, 2008). A sua avaliação individual tem vindo a ser cada vez mais rara no contexto de saúde/doença. Tendo em conta que os transtornos psicológicos mais frequentes na população oncológica são a ansiedade, depressão, stresse e as perturbações do ajustamento. Utilizam-se com maior instrumentos que combinam a avaliação em conjunto de alguns desses quadros sintomatológicos. Constituindo uma forma mais económica de recolha dos dados no contexto oncológico, pessoas já em si vulnerabilizadas pela condição de doença. Assim, por questões éticas são cada vez mais utilizados e recomendados instrumentos reduzidos 
(versões brief) (Pais-Ribeiro, 2007), dos quais a Hospital Anxiety and Depression Scale (HADS) (Zigmond \& Snaith, 1983) é mais utilizada dentro dos modelos mistos de ansiedade/depressão (versão portuguesa, Silva, Pais-Ribeiro \& Cardoso, 2006) e a Depression Anxiety Stress Scales (DASS) (Levibond \& Levibond, 1995), também adaptada para a população portuguesa (EADS, Pais-Ribeiro, Honrado \& Leal, 2004), no caso dos modelos tripartidos de depressão, ansiedade e stresse. Por essa razão, são encontrados na literatura mais estudos referentes a estes modelos do que à avaliação da ansiedade isoladamente em doentes com cancro.

A literatura consultada que passamos a apresentar baseia-se nos modelos acima descritos de avaliação dos distúrbios psicológicos na população oncológica.

Os estudos de avaliação dos modelos mistos ansiedade/depressão dão conta de maior prevalência de ansiedade comparativamente com a depressão em doentes com cancro da mama. Lueboonthavatchay (2007) identificou distúrbios de ansiedade em $16 \%$ das doentes e apenas $9 \%$ de depressão. Verificou ainda uma prevalência da ansiedade de $19 \%$ e de depressão de $16.7 \%$. Níveis elevados de ansiedade foram encontrados por Tapadinhas (2004) numa amostra de doentes com cancro da mama. A autora encontrou ainda relação estaticamente significativa entre os níveis de ansiedade e os níveis de depressão, indicando que a maiores níveis de ansiedade correspondem maiores níveis de depressão.

Doentes com cancro da mama recentemente diagnosticadas com cancro experimentam ansiedade. Hall, Hern e Faloowfield (1999) identificaram perturbação da ansiedade em $49.6 \%$ das mulheres com cancro da mama que receberam recentemente o diagnóstico. Gallagher, Parle e Cairns (2002) acreditam que cerca de 32 a $45 \%$ das doentes apresentam ansiedade clinicamente significativa e 7 a $46 \%$ depressão. Lidar 
com o diagnóstico é o primeiro desafio da trajetória de doença das mulheres com cancro da mama. Outros se lhe seguem acompanhando cada fase do curso da doença.

Um estudo prospectivo realizado por Morris e Royle (1988) envolvendo 30 doentes com cancro da mama em fase inicial, pretendeu avaliar se a participação na opção cirúrgica (mastectomia simples ou mastectomia radical) influi na ansiedade e depressão no pré e pós-operatório. Os resultados demonstram que as mulheres que não participaram na decisão cirúrgica revelaram mais ansiedade e depressão clínica antes da operação, e nos dois e seis meses após a mesma do que as que participaram. Os autores concluíram que a informação e o aconselhamento adequado dos doentes sobre os procedimentos cirúrgicos diminuem a sintomatologia psicopatológica avaliada.

Fernandes (2009) avaliou a prevalência de ansiedade/depressão numa amostra de mulheres com cancro da mama em quatro períodos diferentes, correspondentes a quatro momentos diferentes do processo terapêutico, num primeiro, antes da cirurgia, segundo, duas semanas após a cirurgia, terceiro, durantes os tratamentos, último, final dos tratamentos (entre 9 a 12 meses após a marcação de cirurgia). A percentagem de ansiedade foi superior em todos os momentos $(78.4 \%, 60 \%, 50 \%$, e $37 . \%$, respetivamente), comparativamente com a depressão, nos mesmos momentos cronológicos $(37.8 \%, 37.8 \%, 20.6 \%$ e $20 \%$, respetivamente). A fase dos tratamentos em que as doentes se encontram parece ser assim determinante na experiência da ansiedade, é maior durante a realização dos mesmos, tendendo a diminuir quando estes terminam. Após o diagnóstico e após a cirurgia são os períodos mais críticos em termos de ansiedade, mas também de depressão.

Os períodos pré e pós cirurgia da trajetória da doença são propensos a níveis mais elevados de ansiedade e depressão nas mulheres com cancro da mama, 
encontrando justificação nos receios e expectativas face à vida em função da imagem corporal, aparência física e sexualidade (Granz, Schag, Lee, Polinky \& Tan, 1992; Montgomery \& Bovbjerg, 2004). Tratam-se de respostas emocionais perante fantasmatização das repercussões da mutilação física e elaboração psíquica da perda de um membro, neste caso, símbolo por excelência da feminilidade.

Maraste, Brandt, Olsson e Reyde-Brandt (1992) num estudo acerca da relação entre a ansiedade/depressão a idade e o tipo de cirurgia em doentes com cancro da mama antes de iniciarem radioterapia, observaram a presença superior de ansiedade mórbida num grupo de doentes mastectomizadas na faixa etária dos 50-59 anos de idade comparativamente com as da cirurgia conservadora, enquanto aguardavam o início do tratamento.

Burgess, Cornelius, Love, Graham, Richard \& Ramirez (2005) avaliaram a prevalência da ansiedade/depressão em 222 mulheres com cancro da mama, cinco anos após o diagnóstico. Verificaram que cerca de $50 \%$ das participantes tiveram ansiedade, depressão ou ambas no primeiro ano após o diagnóstico, $25 \%$ no segundo, terceiro e quarto, e $15 \%$ no quinto. A prevalência de ansiedade um ano após o diagnóstico foi superior à da depressão (33\% e 15\%, respetivamente). Torres, Pereira, Monteiro, Pinto, Correia, Gonçalves, et al. (2010) encontraram apenas ansiedade severa em 4.2\% numa amostra de sobreviventes do cancro da mama. Okamuna, Yamawaki, Akechi, Taniguchi, e Uchitomi (2005) avaliaram os fatores associados aos transtornos psiquiátricos e o impacto na qualidade de vida em 50 doentes com cancro da mama em primeira recidiva da doença através de entrevista estruturada do DSM-IV. Os autores verificaram que $20 \%$ das doentes reuniam requisitos para o diagnóstico de transtorno de ansiedade generalizado. Fica assim demonstrado que a ansiedade acompanha as doentes com cancro da mama ao longo de todas as fases do curso da doença. 
Montazer, Jarvandi, Haghight, Vahdani, Sajadian, Ebrahimi et al. (2001) avaliaram o impacto a longo prazo da frequência de grupo de apoio na prevalência da morbilidade em 56 doentes com cancro da mama. Antes do estudo, $29 \%$ das doentes revelava índices elevados de ansiedade e 14\% revelava índices igualmente consideráveis de depressão. Após a participação no grupo a ansiedade e a depressão diminuiu significativamente. As intervenções psicológicas, individuais ou de grupo, desempenham um papel importante na redução da ansiedade e depressão, promovendo um melhor ajustamento à doença e tratamentos (Sheard e Maguire, 1999).

\section{I.4.2.3. Depressão}

\section{4.2.3.1. Definição}

Quando falamos em depressão imediatamente outros conceitos lhe são associados. Tristeza, melancolia, humor, afetos e emoções. Consideramos pertinente efetuar duas principais diferenciações. Em primeiro lugar distinguir depressão, tristeza e melancolia. Em segundo lugar, humor, afetos e emoções.

A depressão é uma das patologias mais antigas e frequentes (5\% a 10\%) na população em geral. A melancolia continua a ser o quadro clínico mais típico, ainda não seja o mais numeroso. Segundo o Dicionário de Psicologia (Doron \& Parot, 2001) a depressão é caracterizada pelo humor depressivo e lentificação psicomotora, aos quais se associam outros sintomas, variáveis entre sujeitos, que completam o quadro: culpabilidade, desespero, visão pessimista da vida e da existência, sintomatologia somática (insónia, astenia, oscilações de peso e apetite), por vezes, ideação suicida, que deverá ser sempre objeto de particular atenção. 
Ainda segundo mesmo dicionário, as referências à melancolia remontam à antiguidade clássica, período no qual era considerada perturbação psíquica resultante do desequilíbrio entre os quatro humores fundamentais: sangue, linfa, bílis amarela e bílis negra. Sendo a causa da melancolia associada a este último. No início do século XIX, aquando das primeiras descrições das semiologias mentais, a melancolia foi definida como delírio. Anos mais tarde essa associação é abandonada e os sintomas de melancolia passam a ser definidos: tristeza, indiferença afetiva, lentificação motora e psicológica. A partir de então o conceito clássico de melancolia sofre outras perfilhações passando a ser substituído pelo termo depressão (Vallejo, 1999). No entanto, para alguns autores os limites entre ambas continuam por esclarecer. Para Doron \& Parot (2001) a depressão é mais ampla que a melancolia. Contém melancolia, mas não se restringe a ela.

Na obra Luto e Melancolia, Freud destinge ambos os termos, define luto como reação normal à perda da pessoa amada e melancolia com estado psicopatológico, caracterizado por estado de ânimo profundamente doloroso, acompanhado pela perda do interesse pelo mundo externo, perda da capacidade de amar, perda da capacidade de realizar e depreciação de Si-mesmo (Feliming, 2003).

Já a tristeza é um estado natural ou acidental de desgosto, melancolia (Enciclopedia Larousse, 1999). Um estado de insatisfação, mal-estar, abatimento, angustia, inquietação; estado que provoca abatimento, estado depressivo ou nostalgia; pena, mágoa, aflição, consternação, saudade (Dicionário de Língua Portuguesa, 1999). A tristeza é para Cardoso (1993) uma qualidade do humor adjetivada no oposto á alegria. Antropologicamente, como todos os outros sentimentos e emoções (medo, angustia, ansiedade) são inerentes à condição humana. 
No que respeita à segunda diferenciação. O humor deprimido é a principal característica semiológica da depressão clínica (Cardoso, 1993). Corresponde à expressão emocional de um dado plano afetivo num dado momento, podendo ser a sua génese de natureza estrutural ou ambiencial. Guimarães-Lopes (2005) define o humor como disposição ou estado afetivo que confere ao que é vivenciado uma "tonalidade afetiva"; o sentimento como o modo íntimo de sentir o afeto; e a emoção a forma de expressar o que afeta (corporal e circunstancialmente).

Efetivamente, a diferenciação do afeto face à emoção e sentimentos persiste ainda pouco clara no que respeita à limitação das suas fronteiras. Todavia, a afetividade trata-se de um estado de humor, disposição, neste sentido é uma característica da personalidade. Por sua vez, a síndrome depressiva é uma perturbação da afetividade, cuja principal característica é o humor depressivo (Bergeret, 1997), daí a relação entre os conceitos.

O termo depressão é utilizado em três sentidos: sintoma, síndrome e distúrbio (doença). Enquanto sintoma pode acompanhar outros transtornos psíquicos; como síndrome agrupa um conjunto de sintomas constituídos por tristeza, inibição, culpa, desvalorização pessoal, perda de energia; como doença é delimitado por uma etiologia, clínica, curso, prognóstico e tratamento específico (Vallejo, 1999).

Passamos agora à caracterização da depressão clínica. Na DSM-IV (1996) a depressão enquadra-se no capítulo das perturbações do humor, que podem ser de natureza episódica (episódios de alteração do humor) e perturbações do humor, propriamente ditas. Os critérios de diagnóstico segundo o referido manual são: A. Presença de pelo menos cinco (ou mais sintomas) num período de duas semanas, provocando alteração do funcionamento habitual da pessoa; acompanhado de pelo 
menos um dos sintomas (1) humor depressivo ou (2) perda de prazer ou interesse. (1) humor depressivo durante a maior parte do dia, quase todos os dias, indicados por relato subjetivo (do próprio) ou pela observação de terceiros; (2) diminuição acentuada do interesse e prazer em todas ou quase todas as atividades durante a maior parte do dia, quase todos os dias (por relato subjetivo ou descrição de terceiros); (3) perda de peso (quando não se está de dieta) ou aumento significativo de peso, ou diminuição ou aumento do apetite quase todos os dias; (4) insónia ou hipersónia quase todos os dias; (5) agitação ou inibição psicomotora quase todos os dias (subjetiva ou observável por terceiros); (6) fadiga ou perda de energia quase todos os dias; (7) sentimentos de desvalorização ou culpa excessiva ou inapropriada quase todos os dias; (8) diminuição da capacidade de concentração e lentificação do pensamento ou indecisão quase todos os dias; (9) pensamentos recorrentes acerca da morte, ideação suicida recorrente, tentativa de suicídio ou plano específico para o cometer. É importante ressalvar que estes sintomas não preenchem critérios para episódio misto; causam mal-estar clinicamente significativo no funcionamento social e ocupacional ou em outras áreas importantes; não são provocados por nenhuma substância ativa (droga ou medicação) ou por estado físico geral (por exemplo, hipotiroidismo); não são relacionados a processo de luto. Já a Perturbação Depressiva Major é de evolução clínica e caracterizada por um ou mais Episódios Depressivos Major, sem história de Episódios Maníacos, Mistos ou Hipocondríacos. A Perturbação Depressiva Major pode ser de Episódio Único ou Recorrente.

Na CID-10 (1998) a Depressão integra o grupo dos Transtornos do Humor (afetivos), distinguindo igualmente o Episódio Depressivo leve, moderado e grave, do Transtorno Depressivo Recorrente, também leve, moderado ou grave. Neste sistema de classificação, quer o Episódio Depressivo, quer o Transtorno Depressivo Recorrente são 
especificados como acompanhados ou não de síndrome somática. No caso do Episódico com síndrome somática, deverão estar presentes quatro dos seguintes sintomas: (1) acentuada perda de interesse e prazer por atividades habitualmente consideradas agradáveis; (2) falta de reação emocional a eventos ou atividades que normalmente produzem resposta emocional; (3) levantar de manhã duas horas antes ou depois do horário habitual; (4) depressão pior pela manhã; (5) evidência clara de lentificação ou agitação psicomotora (observado por outras pessoas); (6) acentuada perda de apetite; (7) evidente perda de peso (5\% ou mais do peso corporal, no último mês; (8) perda marcada da líbido.

Bergert (1997) apresenta uma caracterização da Síndrome Depressiva por domínios. Ao nível da afetividade predominam os sintomas: tristeza, pesar; ausência de prazer e alegria; sentimento de insensibilidade (incapacidade em ser despertado por sentimentos); sensação de vazio ou petrificação; prostração, desalento, sensação de carrego de fardo pesado; sentimento de culpa; angustia; auto-desvalorização e sentimento de insignificância; ideação suicida.

No que respeita ao pensamento, alteração do pensamento, marcada por pobreza ou ausência de ideias, incapacidade em pensar, inibição do pensamento, incapacidade em tomar decisões, ideias obsessivas e compulsivas; pensamentos hipocondríacos (medo ou suspeita de estar doente); despersonalização (sentir-se estranho, não se reconhecer a sim mesmo); desrealização (sentimento de estranheza face às pessoas e o meio ambiente); alteração da perceção do tempo (sensação de "paragem no tempo" ou que "passa a correr"); delírios de culpa, pecado, castigo, maldição, ruína, entre outros. Relativamente à perceção, podem surgir pseudo-alucinações visuais relacionadas com sombras, morte, esqueleto, e olfativas ("cheiro de putrefação", "Cheiro a cemitério", etc.). 
Na motricidade, como já referido anteriormente, inibição, lentificação ou agitação e inquietação constantes. Sintomatologia somática, acrescenta há anteriormente descrita, diminuição da vitalidade, cansaço, obstipação, alteração dos ciclos menstruais. Por último, mal-estar físico constituído por sintomas como cefaleias, dores nos membros e lombares, sensação de pressão no peito e/ou de dificuldade respiratória, sensação de corpo inchado.

\section{I.4.2.3.2. Depressão e cancro da mama}

A depressão nos doentes oncológicos aparece como reação emocional ao diagnóstico, podendo estender-se às fases seguintes do curso da doença (tratamentos, pós-tratamento, recorrência e progressão da doença, terminal/paliativa) (Carvalho, 2008). É o sintoma psicológico mais comum nos doentes com cancro. Aproximadamente $16 \%$ dos doentes apresentam depressão major, e cerca de $22 \%$ manifestam depressão minor e distimia combinada (Mitchell, Chan, Bhatti, Hulton, Grassi, Johansen, et al., 2011). Valores diferentes, ainda que não muito díspares, são

referidos noutros estudos, $11.8 \%$ (Akechi, Okuyamat, Sugawara, Nakano, Shima \& Uchitomi, 2004) e $18.3 \%$ (Raison \& Miller, 2003).

Os doentes com patologia oncológica, têm comparativamente com doentes com outras patologias físicas, perdas várias e alterações no estilo de vida e da vida diária, às quais se associam pensamentos e cognições de doença, suscetíveis de conduzir ao desenvolvimento de diagnóstico do transtorno depressivo, a saber: medos vários, medo da morte, da incapacitação, amputação, da perda de autonomia, dependência, perda do 
emprego, do status social, perdas na imagem corporal (algumas irreversíveis), entre outros (Raison \& Miller, 2003). Desta forma se explica que os sintomas depressivos sejam significativamente frequentes em doentes com cancro deprimidos e não deprimidos, independentemente do estadio da doença (Mitchell, Lord \& Symonds, 2012).

Sintomas mais severos de depressão clínica associam-se a internamentos longos, sofrimento físico, efeitos secundários dos tratamentos, baixa qualidade de vida e ideação suicida (Li, Fitzgerald \& Rodin, 2012). O sofrimento físico provocado por sintomas somáticos decorrentes da doença e dos tratamentos desencadeia o desenvolvimento de quadros de depressão clínica (Mitchell, Lord \& Symonds, 2012). Ainda dito de outra forma, dor e depressão correlacionam-se significativamente. Doentes oncológicos com dor apresentam índices mais elevados do quadro depressivo. Segundo Pimenta, Koizumi \& Teixeira (2000) dor e depressão caminham juntas, uma agrava a outra.

A prevalência dos sintomas depressivos na população oncológica pode variar em função do tipo de cancro, estadio, método de diagnóstico, tipo de tratamento e variáveis sociodemográficas. Do grupo das variáveis sociodemográficas, as que explicam maior variabilidade são a idade, género (a depressão é mais prevalente nas mulheres) e o estado civil. No que respeita à idade, um estudo conduzido por Harris e Maguire (1995), utilizando uma amostra de 520 doentes oncológicos, entre os quais doentes com cancro da mama, pretendiam avaliar se a idade tinha efeitos no ajustamento à doença. Os autores verificaram que os pacientes mais jovens revelam índices mais elevados de ansiedade e depressão. Este grupo de doentes revelam mais preocupações relacionadas com a doença e com os tratamentos, com o futuro, finanças, relacionamentos interpessoais e sexualidade, comparativamente com os mais velhos. Variáveis 
psicossociais como suporte social, vinculação, auto-estima, espiritualidade e religiosidade encontram-se igualmente implicadas na génese da depressão nos doentes com cancro (BrintzenhofeSzoc, Levin, Li, Kissane \& Zabona, 2009).

A depressão é frequente no âmbito geral das patologias físicas. Representando sempre pior evolução, quer do quadro psiquiátrico, quer do quadro da doença física, comprometendo, consequentemente, a adesão terapêutica, associando-se ao aumento da morbilidade do risco de mortalidade. No entanto, neste contexto, corre-se, por vezes ou muitas vezes, o risco do seu subdiagnóstico e sub-tratamento. Dada a comorbilidade de sintomas da esfera da doença física e tratamentos e do quadro depressivo (dor, insónia, fadiga, anorexia, lentificação, desalento, baixa auto-estima, entre outros), onde nem sempre o diagnóstico é feito ou o é com sucesso (Mitchell, Lord \& Symonds, 2012; Teng, Humes \& Demetrio, 2005). Para além do sofrimento psicológico que provoca no doente, constitui um problema nos cuidados de saúde/doença, em geral, e na oncologia, em particular, na medida que os doentes deprimidos aderem menos às propostas terapêuticas, sob prejuízo de comprometer o prognóstico. É altamente impactante na qualidade de vida dos doentes, suscetibilizando ao sentimento de desesperança, e consequentemente ao comportamento suicida (Teng, Humes \& Demetrio, 2005). Por outro lado ainda, está comprovado que o estado depressivo afeta o funcionamento imunológico, vulnerabilizando-o (já por si débil devido aos efeitos, nomeadamente, da quimioterapia), aumenta a libertação de cortisol (hormona do stresse) na corrente sanguínea, aumento o risco de diminuição da sobrevida. Por erra razão, o rastreio, diagnóstico e tratamento deve ser impreterivelmente uma realidade na prestação de cuidados em oncologia (Raison \& Miller, 2003; Tjemsland, Soraeide, Matre \& Matts, 1997); Teng, Humes \& Demetrio, 2005;Trancos, Cardoso, Luengo, Vieira \& Reis, 2010). Porém, um dos fatores que dificulta o diagnóstico da depressão deve-se à 
dificuldade da maioria dos técnicos de saúde em conversar com os doentes sobre as suas emoções (Trancos et al., 2010).

Como podemos ter vindo a perceber, no contexto das respostas emocionais dos doentes com cancro no processo de ajustamento à condição de doença, a literatura faz referência a diferentes estudos de avaliação de diferentes quadros sintomáticos descritos no DSM-IV, como as perturbações do humor (depressivas), perturbações de ansiedade (perturbação de ansiedade generalizada, perturbação aguda de stresse, perturbação pósstresse traumático, as mais comuns no cancro) e perturbações de adaptação. Nem sempre é fácil o diagnóstico diferencial entre todas, designadamente, entre depressão, transtorno de adaptação e transtorno misto de ansiedade/depressão. O transtorno de adaptação com humor depressivo e/ou ansioso é muito frequente. Geralmente estendemse por várias semanas e apresentam intensidade significativa, comprometendo o funcionamento geral do indivíduo, compreendendo agitação psicomotora, medo extremo, insónia, podendo existir risco de suicídio (Tavares, 1999). Raison e Miller (2003) encontraram sintomas mistos de ansiedade/depressão em 12,4\% dos pacientes oncológicos estudados. Os autores comprovaram que as taxas de prevalência da depressão diferem em função do tipo de cancro. Os doentes que registaram índices mais expressivos nos sintomas mistos de ansiedade/depressão foram os do cancro do estômago, pâncreas, cabeça e pescoço e pulmão. As doentes com da mama foram quem apresentaram os scores mais baixos.

Ainda a propósito do problema do diagnóstico diferencial entre transtornos avaliados e diagnosticados nos doentes com cancro. Ritterband \& Spielberger (2001) conduziram um estudo de comparação da depressão em doentes com cancro, doentes psiquiátricos e indivíduos saudáveis. Os autores encontraram scores mais elevados de depressão nos doentes oncológicos comparativamente com o grupo dos controlos 
saudáveis. Todavia, esta diferença apenas revelou relevância estatisticamente significativa na escala somática do Inventário de Depressão de Beck (BDI). Os autores concluíram que os doentes com cancro da mama podem estar a ser erradamente rotulados de deprimidos, quando na verdade, o sofrimento psicológico poderá ser melhor explicado pelos sintomas somáticos decorrentes dos tratamentos oncológicos e não pela existência de transtorno depressivo.

As taxas de depressão nas doentes com cancro da mama são as terceiras maiores de todos os tipos de cancro (Golden-Kreutz \& Anderson, 2004). No entanto, os índices de depressão neste grupo de doentes também registam variações consoantes os estudos. Teng, Hume e Demetrio (2005) defendem que o distúrbio pode ocorrer em $25 \%$ das doentes. Fernandes e McIntyre (2002) identificaram depressão clínica em 65\% das doentes com cancro da amostra estudada. Graner, Cezar e Teng (2008) dão conta de vários trabalhos sobre transtornos depressivos em mulheres com cancro da mama. $\mathrm{O}$ primeiro estudo, realizado numa amostra constituída por 160 doentes, identificou o transtorno afetivo em $22 \%$ das que realizaram mastectomia. Numa fase inicial da doença, $8 \%$ já apresentavam sintomatologia depressiva. Doentes seguidas em ambulatório há cerca de 5 anos, 30\% manifestavam sintomas de ansiedade e depressão. Um outro estudo, envolvendo 133 doentes seguidas em ambulatório, que se encontravam a realizar radioterapia, pós mastectomia/tumeorectomia, apenas foi identificada depressão em $1.5 \%$ das mulheres, todavia foi revelada ansiedade em $14 \%$. Numa outra pesquisa, com 123 doentes, foram observados altos índices de depressão $(50 \%)$ nas mastectomizadas, $50 \%$ nas tumorectomizadas sujeitas a radioterapia e $41 \%$ nas que só fizeram tumorectomia. Outros estudos demonstram ainda uma taxa de depressão moderada ou severa de $26 \%$ em mulheres mastectomizadas e outra de $12 \%$ em mulheres em fase inicial do curso da doença. Um último estudo detetou um índice 
de $32 \%$ de depressão em 166 mulheres que se encontravam a aguardar cirurgia, e de 24\% no momento de realização da biópsia.

A depressão nas mulheres com cancro da mama, segundo a literatura consulta, associa-se a diferentes variáveis relacionadas e /ou despoletadas pelo processo de doença. Golden-Kreutz \& Anderson (2004) encontraram índices significativos de depressão clínica numa amostra de doentes com cancro da mama. Os autores verificaram que o stresse explicava $53 \%$ da sintomatologia depressiva das doentes. Múltiplas relações estatisticamente significativas entre o stresse despoletado pelo aparecimento da doença e os sintomas depressivos, designadamente, a perceção global de stresse, a representação da doença enquanto acontecimento traumático de vida, acontecimentos stressantes decorrentes do adoecimento, nomeadamente, dificuldades financeiras. Green, Krupnick, Rowland, Epstein, Stockton, Spertus, et al. (2000) reportaram que mais do dobro das doentes com cancro da mama da amostra estudada desenvolveram depressão major após o tratamento, sendo o quadro acompanhado de perturbação pós- stresse traumático. Os autores concluíram que a depressão no cancro da mama parece encontrar-se associada à representação traumática da experiência da doença.

O estadio da doença também parecer ser determinante nos quadros de depressão clínica. Moreira, Silva \& Canavarro (2008) encontraram níveis de depressão clínica em $15.7 \%$ de doentes recentemente diagnosticadas com cancro da mama. No grupo das sobreviventes, apenas $1.9 \%$ apresentava sintomatologia depressiva. Torres, Pereira, Monteiro, Pinto, Correira, Gonçalves, et al. (2010) elaboraram um estudo de avaliação da saúde mental em sobreviventes de cancro da mama portuguesas. A psicopatologia mais prevalente que encontraram foi a depressão (15.65\%), apresentando-se sob a forma 
mais severa em $62.6 \%$ das doentes avaliadas. Os resultados de ambos os estudos, ainda que realizados em Portugal, não se revelaram concordantes.

As variáveis sócio-demográficas aparecem relacionadas em alguns estudos com os estados de depressão em mulheres com cancro da mama. Doentes mais escolarizadas apresentam menor tendência para a depressão, e esta atinge níveis mais evidenciados em doentes mais velhas (Tapadinhas, 2004).

A depressão encontra-se em alguns casos de cancro da mama associada à perceção de fraca possibilidade de sobrevivência (Graner, Cezar \& Teng, 2008).

Combinações mistas de quadros de ansiedade/depressão também são frequentemente relatados na literatura sobre cancro da mama (Eping-Jordan, Campus, Osowiecki, Oppedisano, Gerhardt, Primo et al, 1999; Jacobs \& Bovasso, 2000; Payne, Hooman, Theodoulou, Dobik \& Massie, 1999).

A depressão nem sempre é atendida em doentes com cancro da mama. Quando sub-tratada agudiza os sintomas físicos, limita a capacidade funcional e compromete a adesão terapêutica. Assim, avaliar e tratar a depressão no cancro da mama é condição fundamental nos cuidados em oncologia (Fann, Thomas-Rich, Katon, Cowley, Pepping, McGregor, et al. 2008).

\section{I.4.2.4. Outros Sintomas Psicopatológicos no cancro da mama}

Pesquisas nacionais e estrangeiras, nomeadamente levadas a cabo por psiquiatras, identificam outros quadros sintomáticos e clínicos em doentes oncológica da mama. 
Tavares (1999) para além dos habituais transtornos de stresse, ansiedade e depressão, refere outros transtornos por vezes encontrados nos doentes com cancro, que é necessário avaliar e intervir, pois acarretam padrões de adaptação à doença inflexíveis e comprometedores. Os transtornos de personalidade, sendo os mais frequentes a perturbação obsessivo-cumpulsiva, a dependente, a "border-line" e a histriónica. As perturbações somatoformes e esquizofrenia, esta última representa um problema grave no lidar e tratar os doentes com cancro.

Índices clínicos de somatização são frequentemente identificados em doentes com cancro. A somatização é um fenómeno clínico caracterizado pela ocorrência de queixas somática recorrentes, referentes a diferentes sistemas orgânicos, injustificável pela presença de doença somática. Acarretando o recurso recorrente a tratamentos e terapêuticas farmacológicas, na sua maioria, ineficazes. Os indivíduos com transtorno de somatização tendem a descrever as suas queixas de forma exagerada e dramatizada, não obstante, carecem de informações objetivas. Sintomas de ansiedade e humor depressivo são comuns (Ramos, 2007), estando na maior parte das vezes, a ela associados e por eles explicados. O transtorno somatoforme em doentes com cancro interfere com a relação terapêutica, tratamentos e prognóstico, para além de conferir ainda mais sofrimento à experiência de doença (Leite \& Teng, 2008).

Purushotham, Uppori, Klevesath, Bobrow, Millar, Myles et al. (2005) avaliaram a morbilidade física e psicológica após biopsia ao linfonodo sentinela no tratamento ao cancro da mama, utilizando um grupo controlo (linfonodo negativo) e um grupo de estudo (linfonodo positivo). Os resultados indicaram maior somatização no grupo de estudo comparativamente com o grupo controlo, encontrando-se esta positivamente correlacionada com a ansiedade. Encontraram igualmente mais sensibilidade interpessoal no grupo de estudo que no controlo. 
Rodrigues, Cunha e Pereira (2012), num estudo comparativo entre mulheres mastectomizadas e histerectomizadas encontraram índices superiores de ideação paranóide nos grupos das mastectomizadas.

\section{I.4.2.5. Intervenção Terapêutica na sintomatologia psicopatológica}

"Todas as teorias e ciências do mundo juntas não poderão ajudar tanto alguém como um ser humano sem medo de abrir o seu coração a outro". (Elisabeth Kübler-Ross, 2008, p. 166).

"Não me encontro preparada psicologicamente para ser operada. (...) Sr. ${ }^{a} \mathrm{Dr} .{ }^{a}$ indique-me onde posso encontrar essa ajuda. Preciso de um psicólogo. Se não tiver ajuda a operação não vai correr bem, eu sei (...)",

(Doente com mastectomia marcada, 54 anos)

Considerar o adoecer o cancro da mama sinónimo de afeção psicopatológica, é um pensamento reducionista, irrealista e estigmatizante. Se é verdade que o sofrimento, como vimos anteriormente, estará sempre mais ao menos presente no percurso experiencial do processo de doença, a presença de sintomatologia psicológica clínica nem sempre se verifica. Porém, também como já elucidado, a experiência de sofrimento quando não atendida poderá evoluir para quadros psicopatológicos.

Os avanços da medicina, responsáveis pelo aumento da sobrevivência, aumentam a familiaridade com a realidade da doença, sendo cada vez mais conhecidos casos de cura, aliados às acessibilidades de informação sobre a doença, veiculadas pelos órgãos de comunicação social, internet e pela entre-ajuda entre doentes, têm vindo a promover melhor ajustamento psicossocial à doença. Tornando-se cada vez mais uma realidade a existência de doentes com cancro da mama ajustadas, otimistas e com bemestar psicológico. Contudo, outros casos existem, que efetivamente padecem de 
perturbação psicológica decorrente da situação de doença e dos tratamentos, justificando-se a necessidade de intervenção clínica psicoterapêutica. Pois a presença destes quadros constituem um ameaça na trajetória da doença, na medida que debilitam o sistema imunitário, já vulnerável pelos tratamentos, comprometendo a adesão e a eficiência da terapêutica oncológica (Ibánez, Valiente \& Soriano, 2001; Justo, 2001; Ogden, 2004; Vasquéz, Rodrugues \& Alvaréz, 1998; Teixeira \& Pereira, 2011; Tjemsland, SØreide, Matre \& Malt, 1997; Veit \& Carvalho, 2008). Tjemsland, SØreide, Matre \& Malt (1997), constataram que a presença de sintomas psicológicos de stresse e depressão na semana antes da cirurgia interferem com o sistema imunitário.

Gill et al. (2001) defendem que a intervenção psicológica junto de pacientes oncológicos deverá assentar em farmacologia, counselling e psicoterapia. Os autores destacam a eficácia da Psicoterapia Comportamental, da Psicoterapia de Procura de Significado («Meaning-Seeking Psychoterapy de Holland \& Goooen-Piels, 2000), da Psicoterapia Existencial e da Terapia de Grupo de Expressão-Suporte (Spiegel et al., 1999) junto da população oncológica. A escrita de expressão emocional (Gadler, 2005). Durá e Ibáñez (2000) acrescentam que as intervenções psicossociais em psicologia oncológica podem variar entre as terapias breves, de intervenção em crise, até aos programas ou psicoterapia de longa duração, que se estendem até ao final dos tratamentos. Dando como exemplos a terapia clássica (individual), terapia didática, a terapia de grupo ("grupos de apoio social" e "grupos de autoajuda"), e a nível social e comunitário, as campanhas de informação e prevenção.

Independentemente do modelo terapêutico a seguir, a intervenção psicooncológica, segundo Rojas-May (2007), com a paciente e família deve ser ajustada às fases processuais do curso da doença, a saber: diagnóstico, tratamento, intervalo livre de 
doença, sobrevivência, recidiva e fase terminal. Pois cada fase tem exigências e sintomatologia específica.

Estudos demonstram que a psicoterapia aos doentes oncológicos e família tem um impacto significativo no ajustamento à doença e tratamento, bem como, no prognóstico (Pereira \& Lopes, 2002). Justo (2001) defende que as intervenções psicológicas adjuvantes contribuem para o ajustamento emocional ao diagnóstico e tratamentos, facilitam a colaboração dos utentes com os profissionais de saúde, melhoraram o funcionamento psicológico e imunológico, promovem o aumento da sobrevida com melhor qualidade. O autor acrescenta que estas intervenções têm efeitos significativos em termos de custo/benefício, nem sempre contempladas pelos respetivos serviços de saúde. Promove a resignificação da experiência de doença e do sentido da vida e potencia o crescimento pessoal (Remondes-Costa \& Pais-Ribeiro, 2012). Outros estudos defendem que contribuem para sobrevivência e longevidade dos doentes (Coyne, Hanisch \& Palmer, 2007). Assim, o seu aconselhamento e prescrição deveria fazer parte dos cuidados fundamentais do protocolo oncológico.

\section{I.4.2.5.1. Intervenções de Grupo com mulheres com cancro da mama}

“ O grupo permitiu que eu me libertasse mais. Conseguisse falar sobre as minhas ansiedades, medos e projetos para o futuro. Aumentou a minha auto-confiança na forma de lidar com a doença, diminuiu os meus medos e ansiedades".

(Tumorectomizada, 34 anos)

A experiência de doença do cancro da mama coloca muitos desafios às doentes. Por essa razão, doentes oncológicas e familiares solicitam apoio psicossocial. Embora muitas doentes enfrentem o processo apenas com o apoio dos familiares e amigos, o 
apoio psicossocial institucionalizou-se. Conhecem franca expansão as consultas especializadas de psico-oncologia nos hospitais gerais e institutos de oncologia, mais recentemente na Liga Portuguesa Contra o Cancro, quer nos meios urbanos, quer nos meios rurais. Este apoio tem vindo a conhecer aumento da procura por das doentes e familiares, de tal forma, que os serviços começam a evidenciar congestionamento. Tendo em conta que o cancro da mama é o cancro feminino mais frequentemente em todo o mundo, e demonstrada a eficácia da intervenção terapêutica junto das doentes, em termos clínicos e empíricos, o número de pedidos de apoio psicossocial por doentes com cancro da mama tem vindo a aumentar. Daí que para evitar a saturação dos pedidos de consulta individual, seja impreterível apostar na intervenção terapêutica em grupo.

A formação de grupos com pessoas que experimentam situações de vida ameaçadoras à sua saúde e à existência humana são de reconhecido potencial terapêutico. Aliando aos benefícios terapêuticos da participação em grupo, o igualmente benéfico, fornecimento de suporte social, bem como, a redução de custos em saúde, na medida que com menos recursos humanos se ajuda um maior número de pessoas (Guerra \& Lima, 2005). Exemplos desse modelo de eficácia são os grupos de auto-ajuda de mulheres com cancro da mama, como o "Movimento Vencer e Viver" da Liga Portuguesa Contra o Cancro, grupos de auto-ajuda de mulheres mastectomizadas e os mais recentes foros de discussão na internet entre doentes. A pertença a um grupo que partilha uma experiência comum favorece a crença da compreensão e o laço da proteção por conseguinte, o reconhecimento da eficácia da ajuda. O caso particular dos grupos de discussão na internet podem constituir uma ajuda fundamental para doentes que por incapacidade decorrente da realização de tratamentos, não se sente com energia para sair de casa e procurar formas de ajuda convencionais (Maia, 2009). Todos têm em comum a partilha da experiência de doença, e o reconhecimento da eficácia dessa ajuda. 
Gittlieb e Wachala (2007) efetuaram uma revisão crítica de 44 artigos sobre grupos de apoio profissional dirigidos a doentes com cancro, 32 basearam-se em resultados clínicos obtidos, dois em avaliação do processo e 10 na avaliação dos doentes. Os autores encontraram elevada satisfação da parte dos consumidores e efeitos significativos na qualidade de vida e prolongamento da vida. Outros estudos proclamam a obrigatoriedade da introdução de intervenções psicossociais de grupo nos cuidados básicos de saúde em oncologia (Liberman, 2007; Schou, Ekeberg, Karesen \& SorenSem, 2008)

Em Portugal, o desenvolvimento da Psicologia da Saúde na última década, fomentou o interesse pela elaboração, aplicação e avaliação da eficácia de programas de intervenção psicossocial em oncologia (McIntyre, Fernandes \& Pereira, 2002). A Universidade do Minho tem vindo a desenvolver este tipo de programas, dirigidos a pacientes com patologia oncológica, a implementar em serviços de oncologia. Diferentes programas de intervenção psicológica em grupo dirigidos a patologia oncológica diversificada, em diferentes fases da doença, foram estruturados por módulos, correspondendo cada módulo a uma das fases da doença oncológica. Bem como, programas breves de intervenção psicológica para doentes em quimioterapia, estruturados por sessões (seis sessões de 90 minutos cada). Tinham como objetivo trabalhar a adesão ao tratamento, dor, morbilidade psicológica, efeitos colaterais do tratamento, stresse, suporte social, crenças relativamente à doença e a relação profissional de saúde-doente.

Um programa breve de intervenção de grupo para mulheres mastectomizadas, foi estruturado em quatro sessões, com objetivo de trabalhar a adesão ao tratamento, morbilidade psicológica, stresse, dor, crenças relativas à doença, imagem corporal, 
perdas, relacionamento conjugal e /ou interpessoal (McIntyre, Fernandes \& Pereira, 2002).

A eficácia de um programa de intervenção psicológica breve em mulheres com cancro da mama, foi avaliada num estudo realizado por Fernandes e McIntyre (2002), estruturado em quatro sessões, destinado a intervir na educação para a importância do apoio psicológico na reabilitação e ajustamento à doença, na melhoria do bem-estar em situação de doença, identificação e gestão de stresse, processos de coping, gestão emocional e comunicação interpessoal. Participaram no estudo 40 mulheres que se encontravam a realizar quimioterapia, 15 constituíram o grupo experimental (com intervenção psicológica) e 25 o grupo controlo (sem intervenção). Os resultados dão conta da diminuição dos níveis de ansiedade e depressão, e da utilização de estratégias de coping de aceitação da doença, distração, desinvestimento mental, expectativas acerca da doença e tratamento, no grupo experimental, após a intervenção.

Mais recentemente, em 2011, Pereira coordena um conjunto de intervenções psicossociais dirigidas as diferentes doenças crónicas, no sentido da promoção da saúde de doentes e familiares, melhoria da qualidade de vida, bem estar e satisfação com a vida. Para o presente trabalho destacamos o Manual de Intervenção pré e pós cirurgia em mulheres submetidas a cirurgia mamária. Tem como objetivo geral a promoção precoce de estratégias de coping na adaptação à doença e a prevenção de sintomas psicopatológicos associados ao diagnóstico e tratamentos do cancro da mama. O programa estrutura-se em quatro módulos, distribuídos por sete sessões individuais e de casal. O primeiro dirigido à fase de diagnóstico da doença, o segundo à fase de preparação para o internamento hospitalar, o terceiro ao período de internamento précirúrgico e o último à fase pós-operatória. 
Em Espanha, o grupo de Estrella Durá da Universidade de Valência (Durá \& Hernández, 2002), defende a pertinência de Programas de Apoio Social, centrados no apoio informativo-educacional e experiencial-emocional, na melhoria da saúde física e psíquica dos doentes oncológicos. No caso concreto das mulheres com cancro da mama, consideram que os grupos terapêuticos e os de auto-ajuda são eficazes no fornecimento de apoio emocional, intercâmbio de informação sobre a doença e entre-ajuda. Sendo as duas primeiras as ajudas mais procuradas nestes tipos de grupos (Remondes-Costa \& Pais-Ribeiro, 2012).

Estudos publicados em revistas internacionais de psico-oncologia demonstram como a ajuda em grupo aos doentes oncológicos se pode aliar às novas tecnologias, novas vias de veiculação da informação sobre doença oncológica e difusão atual do universo das redes sociais eletrónicas. Estas intervenções inovadoras colocam o avanço tecnológico à disposição de um maior número de doentes, a partir de instrumentos eletrónicos de quotidiano, complementando assim as terapêuticas médicas e psicológicas convencionais. São exemplos destes tipos de intervenções os grupos de ajuda de mulheres com cancro da mama na internet (Liess, Simon, Yutsis, et al., 2008; Schaw, Han, Kim, et al., 2007).Os grupos de suporte por videoconferência com mulheres com cancro da mama residentes em meio rural (Collie, kreshka, Ferrier, et al., 2007). A visualização de vídeos com informação multidisciplinar sobre a doença com vista à preparação para os tratamentos (Walker \& Podbilewicz-Schuller, 2005).

A literatura faz ainda a referência a programas de intervenção de grupo que capacitem os doentes oncológicos para o regresso ao trabalho e à participação que este evoca (Rasmussen \& Elverdam, 2008), um passo, em alguns casos, acompanhado de grande insegurança. E grupos de counselling educativo destinados a ajudar companheiros e cônjuges de mulheres com cancro da mama (Lewis, Cochrane, 
Fletchen, et al, 2008). Intervenções de grupo com grupos de sobreviventes de cancro da mama são igualmente de pertinência, aplicabilidade e eficácia comprovada (Araújo, Monteiro \& Torres, 2012; Torres, Pereira \& Monteiro, 2012).

A avaliação da eficácia de programas de intervenção psicológica e psicoterapêutica em oncologia, constituem ainda, segundo Justo (2001), uma realidade recente. Os estudos empíricos de avaliação da eficácia de programas de intervenção psicológica em pacientes oncológicos, ainda continuam a ser escassos, principalmente em Portugal, comparativamente aos estudos de avaliação de necessidades. Seria pertinente o incremento de desenhos de investigação deste tipo, por forma a melhorar a

qualidade de vida dos pacientes durante o processo de doença, por um lado, e a promover o reconhecimento do papel da psicologia oncológica nos contextos de saúde, por outro.

\section{I.4.2.6. Terapêuticas Alternativas no alívio do sofrimento e sintomatologia psicopatológica no cancro da mama}

As terapias alternativas têm vindo a conquistar terreno no campo da saúde, sendo utilizadas de forma co-adjuvante com os tratamentos da medicina clássica ou convencional. Este facto poderá ser justificado pelo reconhecimento recente da Organização Mundial de Saúde (OMS) da acupunctura e do shiatsu como métodos de tratamento eficazes em diferentes doenças. Outros métodos terapêuticos alternativos não viram ainda reconhecidos cientificamente a sua eficiência, apesar muitos doentes referirem alívio de sintomas físicos e psicológicos.

No caso do cancro da mama, diferentes autores, baseando-se nas experiências das doentes, defendem que a utilização de terapias alternativas traz benefícios para a 
qualidade de vida, melhorando o bem-estar físico, psicológico, emocional e espiritual. A acupunctura, a fitoterapia, homeopatia, hipnoterapia, naturopatia, meditação, yoga, visualização, relaxamento, massagens e arte-terapia, estão entre as mais referenciadas Ogden, 2004b; Pennery, Speechley e Rosenfield, 2009).

A eficácia de algumas destas terapias alternativas foi testada em alguns estudos científicos em doentes com cancro. Algumas delas denominadas de "terapias mentecorpo" começam a ser paulatinamente introduzidas nos cuidados aos doentes oncológicos, nomeadamente o relaxamento, hipnose, yoga, meditação, visualização, biofeedback e mindfulness, evidenciando bons resultados (Teixeira \& Pereira, 2011).

A visualização guiada começa a ganhar relevância enquanto intervenção eficaz em psicologia da saúde, revelando bons resultados em doentes oncológicos e noutras doenças (Cabete, Cavaleiro \& Pinteus, 2003).

Um estudo comprovou a eficácia de intervenção psicológica baseada no relaxamento e na imaginação guiada, na redução da ansiedade, depressão e desconforto em doentes com cancro da mama, durante o tratamento (Kissane, Crabsch, Clarck, et. al., 2007) e na qualidade de vida (León-Pizarros, Gich, Barthe, e tal., 2007).

Também a hipnose está a ser introduzida com êxito como terapêutica complementar nos cuidados oncológicos. A sua eficácia é conhecida no alívio dos "afrontamentos" experimentados durante a quimioterapia, obtendo impacto positivo na qualidade de vida, ao nível das atividades diárias, trabalho, lazer, sono, humor, concentração, relacionamento interpessoal e sexualidade (Elkins, Marcus, Sterans \& Rajas, 2007). Foram ainda encontrados resultados significativos sobre o impacto da terapia de grupo de carácter apoio-expressivo no melhoramento da qualidade e proteção contra o stresse e a depressão. 
Outros estudos fazem ainda alusão às vantagens da prática do exercício físico na melhoria da qualidade de vida em doentes sobreviventes (May, Venvoorden, Kanstjens, et. al, 2008). Observando que a exercício físico durante o tratamento adjuvante para o cancro da mama melhora a forma e condição física e a capacidade de realização das atividades da vida diária (Markes, Brockaw, \& Resch, 2009).

Têm sido igualmente objeto de estudo os efeitos dos exercícios de pilates em mulheres com cancro da mama. Os resultados são ainda modestos, segundo os autores, mas de forma unânime são considerados seguros para as doentes e melhoram a capacidade funcional, sendo benéficos para a recuperação dos tratamentos (Eyiogor, Karapolat, Yesil, Uslu \& Durmaz, 2010). Keays, Harris, Lucyshyn \& MacIntyre, 2008). Mas não explicam os efeitos significativos nas variáveis clínicas (Eyiogor, Karapolat, Yesil, Uslu \& Durmaz, 2010).

A prática de yoga em doentes com cancro da mama sobreviventes tem sido relatada em alguns estudos enquanto potencial significativo de atividade física. Resultados indicadores de diferenças significativas entre o grupo de intervenção e o grupo de controlo após a intervenção foram encontrados nas variáveis psicossociais qualidade de vida global e função emocional por Culos-Reed, Carlson, Daroux e Hately-Aldous (2006).

Apesar de ainda só agora recentemente as terapias alternativas começarem a ser associadas aos tratamentos da medicina clássica, e os estudos ainda serem escassos, a continuidade da sua aplicação-avaliação-investigação deverá ser uma premissa, pois os estudos parecem indicar melhoria da qualidade de vida das doentes oncológicas da mama, amenização da experiência de sofrimento, diminuição da medicalização e dos 
seus efeitos secundários. A avaliação do impacto na redução dos custos em saúde também deveria ser investigada. 


\title{
SEGUNDA PARTE
}

\author{
II.- MARCO EMPÍRICO
}




\section{II.1. METODOLOGIA}

Apresentaremos neste capítulo a descrição da metodologia científica utilizada, começando pela caracterização do trabalho quanto ao desenho de investigação, definição do problema e objetivos, hipóteses, caracterização sociodemográfica e clínica da amostra estudada, descrição dos instrumentos utilizados e finalizamos com a sistematização de todos os passos sequenciais do mesmo, os procedimentos.

\section{II.1.1. Desenho de Investigação}

O presente projeto de investigação segue uma metodologia de mista, isto é, quantitativa e qualitativa. Sendo a primeira de carácter exploratório, descritivo, correlacional e transversal (Pais-Ribeiro, 2008). No que refere à segunda, pretendeu-se enriquecer a análise quantitativa com dados recolhidos e analisados qualitativamente, aproveitando assim, o contexto hospitalar de recolha dos mesmos, no qual as variáveis em estudo têm lugar. A metodologia qualitativa efetuou-se no âmbito do trabalho de campo no local onde as doentes realizam os tratamentos, procurando observar dados complementares de pesquisa, como o funcionamento dos serviços, relação dos doentes com os espaço físico, serviços e com os diferentes profissionais de saúde (médicos, enfermeiros, assistentes social, auxiliares de enfermagem, seguranças e administrativos) e com os familiares e amigos que o acompanham às consultas e tratamentos.

A par da observação em contexto natural de saúde, foram registadas narrativas dos doentes contadas na primeira pessoa, aquando da recolha quantitativa dos por hetero-aplicação. Esta metodologia pareceu-nos pertinente para melhor avaliação e 
compreensão das variáveis em estudo e cumprimento dos objetivos, pois segundo Bayés (2004) para o estudo da experiência de sofrimento na doença, “(...) um dos instrumentos metodológicos mais sucintos que se encontram ao nosso alcance para conhecer o que acontece num hospital, a partir do ponto de vista do doente, são as narrativas dos pacientes e dos familiares que com ele compartilham a sua experiência de doença (p. 114). O autor sublinha ainda, que o investigador, sendo uma pessoa externa ao hospital, é a pessoa indicada para desenvolver a observação crítica, salvaguardando assim os doentes de represálias pelo anonimato e confidencialidade.

O cancro como toda a doença, altera e redimensiona a vida social do doente, afetando as suas relações e modificando as suas ações (Aureliano, 2007). CarvalhoTeixeira (2010) defende o estudo da experiência de saúde e doença, a partir das modalidades discursivas que o doente constrói da sua doença e do significado que atribuí a essa experiencia, como uma necessidade científica em psicologia da saúde. No cancro do cancro da mama, o autor acrescenta que a análise fenomenológica do adoecer "constitui uma mais valia para o conhecimento e avaliação de diferentes aspetos psicológicos em mulheres com cancro da mama, decisivos para planear a intervenção" (pp.38-39). Por isso procurámos atender nesta metodologia qualitativa de pesquisa a uma componente antropológica e fenomenológica do adoecer do cancro da mama. Pois acreditamos que para compreender e intervir adequadamente na problemática da experiência de sofrimento na doença nas doentes da mama são necessários mais estudos de metodologia qualitativa baseados na narrativa da experiência de doença e em trabalhos de campo de cariz antropológico e etnográfico (Dias, 2005; Pereira, 2008). 


\section{II.1.2. Definição do Problema e Objetivos}

A experiência de sofrimento na perspetiva subjetiva do doentes, associada à(s) perda(s) concomitantes no processo de adoecer, e numa perspetiva "despatologizada", tem sido pouco abordada na literatura clínica e empírica em psicologia oncológica (McIntyre, 2004). Revelando-se a diferenciação entre sofrimento e sintomatologia psicológica uma questão necessária e oportuna em clínica e investigação, pois até ao momento a experiência de sofrimento na doença é ainda pouco estudada, nunca o tendo sido em mulheres com cancro da mama, nem tão pouco a relação entre as duas variáveis, desta feita, fundamentamos assim a originalidade e pertinência do nosso trabalho.

Integram assim o problema em estudo as seguintes variáveis:

\section{1- Variáveis sociodemográficas}

Tendo sido selecionadas as variáveis consideradas relevantes para a caracterização da amostra utilizada e para posterior relação com as restantes variáveis em estudo, sendo elas: idade, escolaridade, estado civil, profissão, situação ocupacional, agregado e zona de residência.

\section{Variáveis clínicas}

Foram selecionadas as seguintes clínicas: data da realização do diagnóstico, estadio do tumor, caracterização TNM, conhecimento do diagnóstico, prognóstico, sintomas físicos e tratamento atual, por se considerarem oportunas na caracterização do quadro clínico das doentes participantes na amostra, bem como, para o estudo de possível relação com as outras variáveis. 


\section{Experiência subjetiva de sofrimento na doença}

Esta variável subdivide-se em diferentes domínios: sofrimento físico, sofrimento psicológico, sofrimento socio-relacional, sofrimento existencial e expetativas positivas do sofrimento. A pertinência da investigação desta variável na amostra selecionada prende-se com a fundamentação teórica referidas anteriormente, que a experiência subjetiva de sofrimento na doença é pouco valorizada nos contextos de saúde/doença em favorecimento da sintomatologia física e psicopatológica, podendo igualmente concorrer para o comprometimento da adesão terapêutica.

\section{Sintomatologia psicopatológica}

Esta variável apresenta uma dimensão bastante ampla, subdividindo-se em diferentes dimensões, constituídas pelos seguintes os quadros clínicos a avaliar: ansiedade, depressão, somatização, obsessão-compulsão, sensibilidade interpessoal, ansiedade fóbica, hostilidade, ideação paranoide e psicoticismo. Consideramos pertinente o estudo da prevalência da sintomatologia psicopatológica e respetiva gravidade em termos clínicos, uma vez que, como referido anteriormente, para além de causar sofrimento psicológico, afeta e condiciona o relacionamento com os profissionais de saúde, a adesão aos tratamentos e respetiva eficácia dos mesmos, bem como, o prognóstico e a sobrevida.

Tendo em conta que cancro da mama é a doença oncológica mais frequente nas mulheres e responsável pelo maior número de mortes por cancro neste grupo. Factos que tornam o cancro da mama a doença mais temível entre o sexo feminino, e por esse motivo tão impactante na esfera psicossocial das mulheres por ele atingidas. O presente trabalho pretende constituir um contributo para o estudo das variáveis psicológicas 
subjetivas (experiência de sofrimento na doença) e clínicas (sintomatologia psicopatológica) associadas à trajetória de doença em mulheres com cancro da mama.

O presente desenho de investigação pretende responder a três principais problemas:

$1^{\circ}$ - Qual a experiência subjetiva de sofrimento na doença das mulheres com cancro da mama?

$2^{\mathrm{a}}$ - Quais os sintomas psicopatológicos mais frequentes apresentados pelas doentes com cancro da mama?

$3^{\text {o }}$ - É possível traçar um perfil psicológico das doentes com cancro da mama estudadas?

Relacionados a estes três problemas foram definidos cinco objetivos gerais de pesquisa, a saber:

1). Conhecer a experiência subjetiva de sofrimento na doença das mulheres com cancro da mama da amostra em estudo. Este, por sua vez, é constituído por objetivos específicos:

a1). Conhecer as dimensões do sofrimento na doença mais afetadas;

b2). Investigar se a experiência de sofrimento na doença difere em função das variáveis sociodemográficas e clínicas.

2). Avaliar a sintomatologia psicopatológica das mulheres com cancro da mama. Também este objetivo, tem por sua vez, dois objetivos específicos: 
b1). Identificar os sintomas psicopatológicos mais frequentes nas mulheres com cancro da mama da amostra em estudo;

b2). Investigar se os sintomas psicopatológicos diferem em função das variáveis sociodemográficas e clínicas.

3). Perceber qual a relação entre a experiência percebida de sofrimento na doença e a sintomatologia psicopatológica;

a1). Perceber se a experiência de sofrimento na doença poderá ser indicador de sintomatologia psicopalógica;

4). Traçar um perfil psicológico das doentes com cancro da mama a partir da caracterização da experiência de sofrimento na doença e da sintomatologia psicológica observada.

\section{II.1.3.- Hipóteses}

Foram elaboradas as seguintes hipóteses de estudo:

H1 - Prevê-se que as doentes com cancro da mama experimentem sofrimento durante a doença;

H2 - Espera-se que a experiência de sofrimento na doença em doentes com cancro da mama difira significativamente em função das variáveis sociodemográficas: idade, estado civil e escolaridade;

H3 - Postula-se que a experiência de sofrimento na doença em doentes com cancro da mama difira significativamente em função das variáveis clínicas: estadio, sintomas, tratamento, cirurgia e prognóstico; 
H4 - Prevê-se que as doentes com cancro da mama apresentem diferente sintomatologia psicopatológica;

H5 - Espera-se que a sintomatologia psicopatológica das doentes com cancro da mama difira significativamente em função das variáveis sociodemográficas: idade, estado civil, escolaridade;

H6 - Postula-se que a sintomatologia psicopatológica das doentes com cancro da mama varie significativamente em função das variáveis clínicas: estadio, sintomas, tratamento, cirurgia e prognóstico;

H7 -Prevê-se que a experiência de sofrimento contribua para o agravamento da severidade da sintomatologia psicopatológica em doentes com cancro da mama;

H8 - Espera-se ser possível com as variáveis em estudo traçar um perfil psicológico das doentes com cancro da mama estudadas.

\section{II.1.4. Participantes}

Utilizou-se uma amostra sequencial, que segundo Pais-Ribeiro (2008) é o tipo de amostra mais frequentemente utilizada em contextos de saúde, consistindo na inclusão no estudo de todos os participantes que reúnem os critérios de inclusão na amostra, à medida que estes vão aparecendo. Este tipo de amostra é também denominada de amostra de conveniência, na medida que o investigador seleciona os participantes em função do local de recolha dos dados mais conveniente.

Os critérios definidos para a inclusão na amostra foram o diagnóstico de cancro da mama em diferentes fases do curso da doença (diagnóstico, tratamento e remissão/sobrevivência e recidiva), sendo excluídos os quadros de fase terminal, e 
residência na Região de Trás -os-Montes e Alto Douro. Escolhemos estudar o universo da população oncológica da mama da Região Norte Interior do país, por consideramos o facto de distarem geograficamente dos grandes centros urbanos do litoral, se encontrarem pouco estudadas. Os dados foram recolhidos no Centro de Oncologia do Centro Hospitalar de Trás-os-Montes e Alto Douro, nas consultas de seguimento em ambulatório e nos serviços de quimioterapia e radioterapia, por se tratar da Unidade de Saúde Regional à qual acorre o universo que pretendíamos estudar. Esta unidade Hospitalar presta serviços de oncologia às populações dos Distritos de Vila Real e Bragança, de quatro concelhos do distrito de Viseu (Armamar, Lamego, S. João da Pesqueira e Tabuaço) e de um concelho do distrito da Guarda (Vila Nova de Foz Côa), abrangendo as duas regiões da Província de Trás-os-Montes, Nordeste Transmontano e Alto Douro.

As participantes foram selecionadas da população utente dos serviços supracitados, num trabalho que contou com a colaboração, quer do diretor do Centro de Oncologia, quer do responsável clínico pela consulta da mama, e com a boa vontade de todos os oncologistas enfermeiros e administrativos do serviço. A recolha da amostra efetuou-se durante os tempos de espera das consultas e dos tratamentos. Este procedimento permitiu atender a duas preocupações, uma de natureza contextual/institucional, a de não interferir com a dinâmica do serviço hospitalar e com as rotinas das participantes, outra de natureza científica, relacionada com a metodologia e objetivos do estudo, pois como descreve Bayés (2000; 2002) os tempos de espera dos doentes com cancro constitui uma das grandes causas do sofrimento na doença, frequentemente negligenciada pelos médicos e restantes profissionais de saúde.

Todas as participantes assinaram o consentimento informado, antes de responderem aos instrumentos de avaliação. Pois como refere Pais-Ribeiro (2002), os 
direitos, garantias e liberdade dos utentes devem ser salvaguardados. Foram igualmente explicados os objetivos do estudo e procurou-se avaliar a capacidade de compreensão das questões colocadas nos instrumentos de avaliação.

Os questionários foram preenchidos por hetero-aplicação, por um lado, para salvaguardar o preenchimento correto dos instrumentos de avaliação, tendo em conta que a amostra em estudo não tinha familiaridade ao nível da participação em estudos, procurando assegurar que as participantes compreenderam os objetivos do estudo e as questões apresentadas. Por outro lado, era também objetivo do presente trabalho reunir informação complementar aos dados quantitativos, recolhendo através das narrativas das doentes na primeira pessoa, "frente a frente" e "aqui e agora", dados qualitativos que nos permitissem compreender mais aprofundadamente a experiência de doença das doentes com cancro da mama. A forma como vivem a doença e perspetivas que fatores poderão interferir com o curso da mesma.

Assim, enquanto se procedia à aplicação dos instrumentos, as participantes do estudo partilharam alguns acontecimentos relacionados com a situação de doença e outros anteriores a doença. Estes dados foram anotados em diário de bordo.

Passamos em seguida a descrever na generalidade as características sociodemográficas e clínicas da amostra estudada, seguindo-se uma descrição mais exaustiva no capítulo da apresentação dos resultados.

\section{II.1.4.1. Caracterização Sociodemográfica da Amostra}

Fizeram parte da amostra 104 mulheres com cancro da mama com idades compreendidas entre os 29 e os 82 anos de idade $(\mathrm{M}=55.22 ; \mathrm{DP}=13.07)$, na sua 
maioria residentes no concelho de Vila Real 46 (44.2\%), e as restantes (55.7\%), noutros concelhos dos distritos de Bragança e Viseu, ambos na zona norte interior do país.
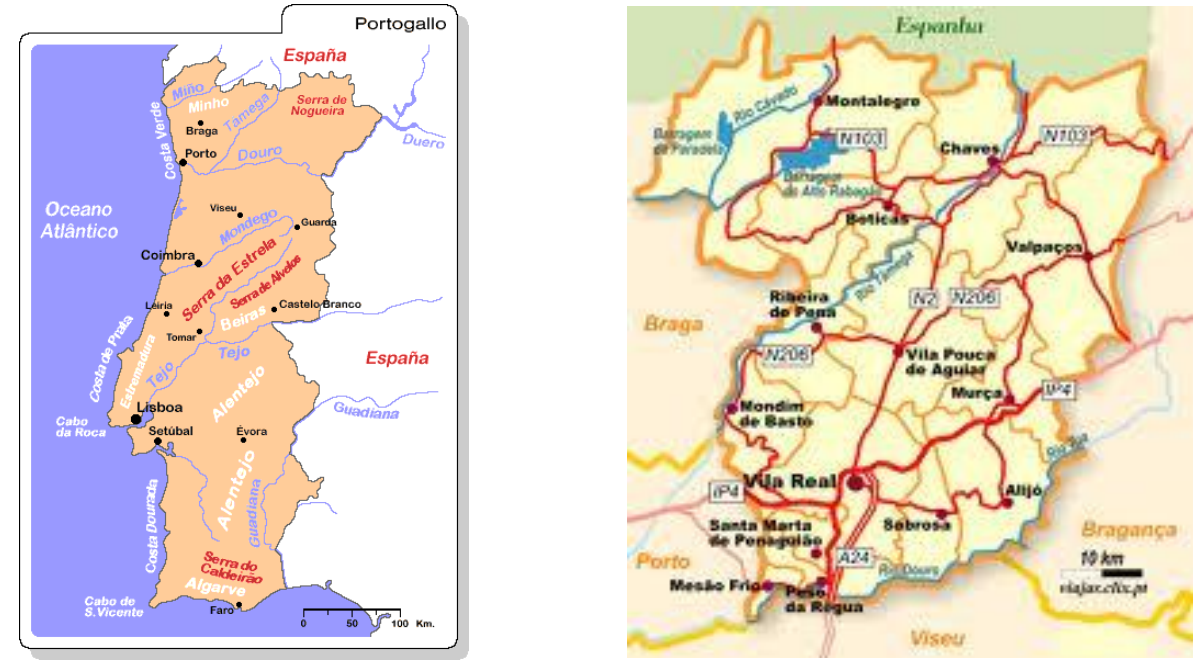

Figura 2: Mapa de Portugal e Distrito de Vila Real Fonte: Google imagens

No que respeita ao estado civil a generalidade das doentes são casadas 71 (68.27\%). Quanto à escolaridade, a maioria (43\%) possuem apenas o $1^{\mathrm{o}}$ ciclo de escolaridade, $21(20.19 \%)$ completo e 22 (21.15\%) por completar. A atividade profissional que mais caracteriza a amostra de doentes em estudo é a de doméstica 43 (41\%). No que refere à situação ocupacional, as doentes encontram-se em maior número reformadas $37(35.50 \%)$ e $20(23 \%)$ de atestado médico. A maioria das doentes apresenta um agregado familiar constituído pelo marido e filhos 44 (42.31\%). 


\section{II.1.4.2. Caracterização Clínica da Amostra}

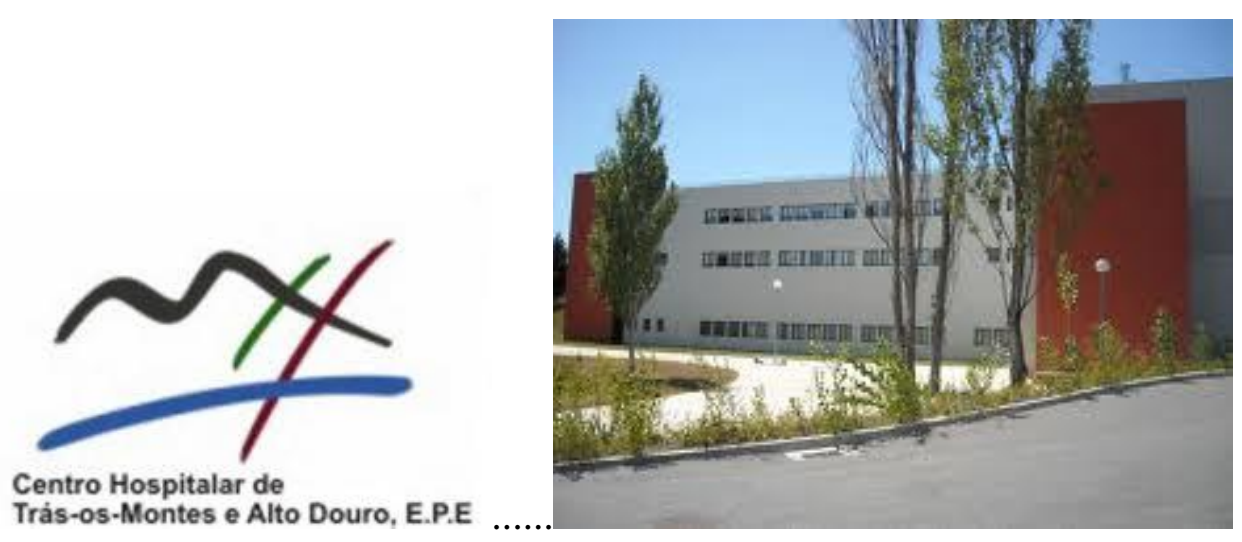

Figura 3: Centro de Oncologia do Centro Hospitalar de Trás-os-Montes e Alto Douro, Vila Real

Fonte: Google imagens

As 104 mulheres com cancro da mama participantes no estudo encontram-se em diferentes fases do curso da doença, registando-se em maior número as doentes diagnosticadas há mais de 25 meses. Na generalidade das participantes o estadio da doença caracteriza-se a nível loco-regional 49 (50.52\%), e a mastectomia radical foi a cirurgia realizada pela maioria $65(75.03 \%)$. No que respeita aos tratamentos, 49 $(48.04 \%)$ realizam outros tratamentos, nomeadamente, hormonoterapia e $38(37.25 \%)$ quimioterapia. O diagnóstico é conhecido pela generalidade das doentes 97 (93.3\%). A maioria das doentes 51 (50\%) têm um prognóstico razoável, não obstante, 31 (30.39\%) têm mau prognóstico.

\section{II.1.5. Instrumentos}

Para avaliar as variáveis em estudo foram utilizados dois questionários e duas escalas. Procuramos utilizar instrumentos que não fossem muito extensos, acatando as recentes normativas da avaliação psicológica em contexto de saúde com população 
doente, por forma salvaguardar a pessoa com doença física, por si já fragilizada por essa condição (Pais-Ribeiro, 2007; 2000).

Foram construídos dois questionários, um para recolha dos dados sóciodemográficos, outro das variáveis clínicas relacionadas com as características da doença e do diagnóstico oncológico, de preenchimento pelo clínico. Foi ainda elaborado Consentimento Informado a fim de ser assinado pelos participantes como sinal de sua autorização na participação do estudo. $O$ sofrimento na doença foi avaliado pelo Inventário de Experiências Subjetivas de Sofrimento na Doença (IESSD) e os sintomas psicopatológicos através do Breif Symptom Inventory (BSI). Passamos seguidamente a apresentar a descrição e caracterização dos instrumentos e suas propriedades psicométricas.

\section{II.1.5.1. Consentimento Informado}

O Consentimento Informado foi elaborado com base na Declaração de Helsínquia, na qual se preconiza que em toda a investigação com sujeitos humanos, cada participante deverá ser informado dos objetivos da mesma, método, instituição a que o investigador está vinculado, bem como, eventuais benefícios ou riscos dessa participação (Pais-Ribeiro, 2002).

O consentimento informado foi apresentado na folha de rosto do questionário, na medida que a sua obtenção, para além de ser um aspeto fundamental na investigação em saúde, a sua assinatura demarca a motivação na participação.

Constam do consentimento informado as seguintes componentes: a). apresentação da investigação e dos seus objetivos; b). clarificação do pepel do 
participante; c). definição do papel do investigador; d). assinatura do participante, atestando a sua concordância em fazer parte do estudo.

\section{II.1.5.2. Questionário de Dados sócio-demográficos}

Do questionário Sociodemográfico fizeram parte as variáveis: idade, zona de residência, escolaridade, estado civil, profissão, situação ocupacional e agregado familiar. Por serem aquelas que nos pareceram necessárias para caracterizar a população alvo e pertinentes na correlação com as outras variáveis.

\section{II.1.5.3. Questionário História da Doença Oncológica}

Foi construído um Questionário Clínico História da Doença Oncológica com base no Sistema de Classificação Internacional TNM - Classification of Malignant Tumours (Wittekind, Greene, Hutter, Klimfinger \& Sobin, 2004), de preenchimento pelo profissional de saúde. No quadro 1 encontram-se os critérios de classificação TNM.

\section{Quadro 1}

Dimensões do Questionário História da Doença Oncológica

\begin{tabular}{|c|c|}
\hline 1) - Data de realização do diagnóstico & $\begin{array}{l}\text { 1). 1-3 meses; 2). 3-6 meses; 3). 6-12 meses; 4). 13-24 meses; } \\
\text { 5). + } 25 \text { meses }\end{array}$ \\
\hline 2) - Estádio do tumor & 1). Local; 2). Loco-regional; 3). Metatático; 4). Desconhecido \\
\hline \multicolumn{2}{|l|}{ 3) - Classificação TNM } \\
\hline \multirow{4}{*}{$\mathbf{T}-$ Tumor Primário } & Tx - o tumor não pode ser avaliado; \\
\hline & To - não há evidência de tumor primário; \\
\hline & Tis - carcinoma in situ \\
\hline & Tamanho - T1, T2, T3, T4 \\
\hline \multirow[t]{3}{*}{$\mathbf{N}$ - Linfonodos Regionais } & $\mathrm{NX}$ - os linfonodos não podem ser avaliados; \\
\hline & No - ausência de linfonodos regionais; \\
\hline & Comprometimento dos linfonodos - N1, N2, N3 \\
\hline M - Metástase à Distância & Mx - a presença de metástases à distância não pode ser \\
\hline & avaliada; \\
\hline & Mo - ausência de metástases à distância; \\
\hline & M1 - metástases à distância \\
\hline 4) - Conhecimento do Diagnóstico Oncológico & 1). Conhece; 2). Suspeita; 3). Ignora \\
\hline 5) - Prognóstico & $\begin{array}{l}\text { 0). Bom; 1). Razoável; 2). Mau; 3) desconhecido; 4). Fase } \\
\text { terminal }\end{array}$ \\
\hline 6) - Sintomas Físicos & $\begin{array}{l}\text { 0). Ausente; 1). Dor; 2). Astenia; 3). Incapacidade funcional; } \\
\text { 4). Outros }\end{array}$ \\
\hline 7) - Tratamento Atual & 0). Nenhum; 1). Radioterapia; 2). Quimioterapia; 3). Outros \\
\hline
\end{tabular}




\section{II.1.5.4. Inventário de Experiências Subjetivas de Sofrimento na Doença (IESSD)}

O Inventário de Experiências Subjetivas de Sofrimento na Doença (IESSD) (McIntyre \& Gameiro, 1999) é um instrumento de avaliação do constructo "sofrimento na doença". Foi elaborado a partir de metodologia mista (quantitativa e qualitativa), pois pretende avaliar o caracter subjetivo da experiência da doença, por isso se baseou na entrevista semi-estruturada a doentes adultos internados em unidades de medicina interna. Tem como finalidade determinar a intensidade da experiência subjetiva de sofrimento na doença na dimensão global e nas cinco dimensões do sofrimento (Gameiro, 1999a ; Gameiro, 1999 ${ }^{\text {b }}$ McIntyre \& Gameiro, 1999). O IESSD vem colmatar a lacuna existente a nível nacional e até mesmo internacional, de instrumentos de avaliação da experiência de sofrimento na doença na perspetiva do doente, sendo o primeiro instrumento português a fazê-lo (Gameiro, 1999a; Gameiro, 1999b; McIntyre, 2004; McIntyre \& Gameiro, 1999). A sua validação foi efetuada numa amostra de 125 doentes adultos selecionados de modo consecutivo entre os doentes internados em 12 unidades de internamento de dois hospitais centrais (medicina interna, cirurgia, ortopedia e ortotraumatologia). Na versão inicial era constituído por 62 itens, mas como os autores pretendiam uma versão menos extensa, mantendo a mesma carga fatorial, com base na análise correlacional de cada item com o valor global e de sub-escala (r>.20) e sua correlação com o alfa de Cronbach, foram eliminados 21 itens, ficando a versão final do instrumento composta por 44.

No quadro 2 encontram-se descritas as dimensões do IESSD, as temáticas do sofrimento associada a cada uma e os itens correspondentes. 


\section{Quadro 2}

Dimensões do sofrimento do IESSD e sua distribuição pelas temáticas e itens

\begin{tabular}{|c|c|}
\hline Dimensões/Temáticas & Itens \\
\hline Sofrimento Físico & \# 6 Itens \\
\hline Dor & $(23 ; 41)$ \\
\hline Desconforto & $(20 ; 31)$ \\
\hline Perda de vigor & $(1 ; 14)$ \\
\hline Sofrimento Psicológico & \# 13 Itens \\
\hline Alterações cognitivas & $(2 ; 17 ; 18 ; 32)$ \\
\hline Alterações emocionais & $(3 ; 5 ; 6 ; 9 ; 10 ; 19 ; 24 * ; 33 ; 39)$ \\
\hline Sofrimento Sócio-relacional & \# 7 Itens \\
\hline Alterações afectivo-relacionais & $(11 ; 12 ; 22 ; 25 ; 43)$ \\
\hline Alterações sócio-laborais & $(7 ; 34)$ \\
\hline Sofrimento Existencial & \# 16 Itens \\
\hline Alterações da identidade pessoal & $(28 ; 30 ; 35)$ \\
\hline Alterações do sentido de controlo & $(13 ; 16 ; 36)$ \\
\hline Limitações existenciais & $(4 ; 15 ; 21 ; 27 ; 40)$ \\
\hline Limitações no projeto de futuro & $\left(8 ; 26^{*} ; 29 ; 37 ; 42^{*}\right)$ \\
\hline Experiências Positivas & $\begin{aligned} & \# 5 \text { Itens } \\
&\left(24^{*} ; 26^{*} ; 38^{*} ; 42^{*} ; 44^{*}\right)\end{aligned}$ \\
\hline Total & \# 44 Itens \\
\hline
\end{tabular}

* Itens no sentido inverso

A versão final do IESSD possui boas propriedades psicométricas. No que respeita à fidelidade, apresenta elevada consistência interna avaliada através do alfa de cronbach (.93) e do Spearman-Brawn (.88). No que refere às sub-escalas do sofrimento, três delas revelam boa consistência interna, sofrimento físico $(\bar{\alpha}=.85)$; sofrimento psicológico $(\bar{\alpha}=.88)$; sofrimento existencial $(\bar{\alpha}=.85)$, nas outras duas a consistência é mais modesta, ainda que razoável, sofrimento sócio-relacional $(\bar{\alpha}=.76)$; experiências positivas do sofrimento ( $\bar{\alpha}=.69)$ (Gameiro, 1999a ; Gameiro, 1999b; McIntyre \& Gameiro, 1999). O instrumento comporta também boa validade de conteúdo, de constructo (as cinco dimensões explicam, após rotação, $48.2 \%$ da variância total) e variante, todas as dimensões do IESSD se relacionam significativamente $(p<.01)$ com a morbilidade física e psicológica do Inventário de Sintomas de Roterdão, utilizados por alguns autores para avaliar o sofrimento em situação de doença.

A análise da consistência interna, por nós realizada através do Alfa de Cronbach permitiu verificar que o IESSD, face à amostra estudada, apresenta boas capacidades 
psicométricas no que respeita à fidelidade do instrumento, tendo sido obtido Alfa de

Cronbach de .95 , ligeiramente acima do encontrado pelos autores do instrumento (.93)

Resultados pormenorizados sobre a fidelidade podem ser consultados no quadro1.

\section{Tabela 1}

Estatística de distribuição dos itens e coeficientes de consistência interna de Cronbach do IESSD obtidos na amostra em estudo

\begin{tabular}{|c|c|c|}
\hline \multirow[b]{2}{*}{ Itens } & \multicolumn{2}{|c|}{$N=104$} \\
\hline & $\begin{array}{c}\text { Correlação } \\
\text { item-total } \\
\text { corrigido }\end{array}$ & $\begin{array}{c}\text { Alfa } \\
\text { Cronbach se } \\
\text { o item for } \\
\text { eliminado } \\
\end{array}$ \\
\hline 01- Sinto-me mais cansado/a desde que estou doente & .54 & .95 \\
\hline $\begin{array}{l}\text { 02- Penso muito na gravidade e nas consequências da } \\
\text { minha doença }\end{array}$ & .74 & .94 \\
\hline $\begin{array}{l}\text { 03- Sinto-me apreensivola em relação ao que me poderá } \\
\text { acontecer }\end{array}$ & .60 & .94 \\
\hline $\begin{array}{l}\text { 04- Sinto que a doença me está a roubar tempo para } \\
\text { poder fazer aquilo que gostaria }\end{array}$ & .69 & .94 \\
\hline $\begin{array}{l}\text { 05- Sinto dificuldade em suportar o estado de tensão que } \\
\text { a doença me provoca }\end{array}$ & .97 & .94 \\
\hline 06- Desde que fiquei doente sinto-me triste & .70 & .94 \\
\hline $\begin{array}{l}\text { 07- Preocupa-me a ideia de a minha doença me fazer } \\
\text { perder o emprego }\end{array}$ & .40 & .95 \\
\hline $\begin{array}{l}\text { 08- A doença obriga-me a pôr de lado alguns projetos } \\
\text { importantes que tinha em mente }\end{array}$ & .63 & .94 \\
\hline $\begin{array}{l}\text { 09- Desde que estou doente tenho tido momentos de } \\
\text { grande desespero }\end{array}$ & .76 & .94 \\
\hline $\begin{array}{l}\text { 10- Desde que estou doente tenho sentido mais a falta da } \\
\text { minha família }\end{array}$ & .45 & .95 \\
\hline $\begin{array}{l}\text { 11- Tenho receio de que com a minha doença me torne } \\
\text { uma sobrecarga para a minha família }\end{array}$ & .61 & .94 \\
\hline $\begin{array}{l}\text { 12- Angustia-me a ideia de poder deixar as pessoas de } \\
\text { quem gosto }\end{array}$ & .54 & .95 \\
\hline $\begin{array}{l}\text { 13- Não consigo compreender o que está a provocar a } \\
\text { minha doença }\end{array}$ & .45 & .95 \\
\hline $\begin{array}{l}\text { 14- Com a doença tenho perdido muita da minha energia } \\
\text { e força física }\end{array}$ & .67 & .94 \\
\hline $\begin{array}{l}\text { 15- A minha doença deixa-me desiludido/a em relação ao } \\
\text { que esperava da vida }\end{array}$ & .77 & .94 \\
\hline $\begin{array}{l}\text { 16- Desde que estou doente sinto dificuldade em me } \\
\text { controlar e reajo com agressividade }\end{array}$ & .71 & .94 \\
\hline 17- Preocupo-me com as dores que possa vir a ter & .60 & .94 \\
\hline $\begin{array}{l}\text { 18- Tenho dificuldade em deixar de pensar nas coisas } \\
\text { que me poderão acontecer }\end{array}$ & .66 & .94 \\
\hline $\begin{array}{l}\text { 19- Sinto-me revoltado/a perante a minha situação de } \\
\text { doença }\end{array}$ & .67 & .94 \\
\hline $\begin{array}{l}\text { 20- Não consigo encontrar posição para estar } \\
\text { confortável }\end{array}$ & .66 & .94 \\
\hline $\begin{array}{l}\text { 21- Sinto que com a doença perdi a liberdade de decidir } \\
\text { sobre a minha vida }\end{array}$ & .73 & .94 \\
\hline $\begin{array}{l}\text { 22- A minha doença fez-me preocupar com o futuro das } \\
\text { pessoas que me são queridas }\end{array}$ & .59 & .94 \\
\hline 23- Tenho dores difíceis de suportar & .47 & .95 \\
\hline 24- Apesar de estar doente sinto-me tranquilo/a & -.16 & .95 \\
\hline 25- Preocupa-me a ideia de não poder ajudar a minha & .58 & .94 \\
\hline
\end{tabular}


família como antes de adoecer

26- Apesar da minha doença não deixo de fazer planos para o futuro

27- Sinto que já não sou capaz de fazer as mesmas coisas $\quad .56 \quad 94$ que conseguia fazer antes de adoecer

28- A minha situação de doente faz-me sentir pena de $\quad .71 \quad .94$ mim próprio/a

29- Acho que para mim já não vale a pena pensar no $\quad .55 \quad .94$ futuro

30- A doença faz com que me sinta diminuído/a como $\quad .63 \quad .94$ pessoa

31- Sinto uma má disposição física que me impede de $\quad .60 \quad 94$ descansar

32- Tenho receio de ficar com alguma deficiência física $\quad .60 \quad 94$

33- A minha doença causa-me angustia $\quad .77 \quad .94$

34- Preocupo-me com a possibilidade de não ser capaz $\quad .40 \quad 95$ de continuar a "ganhar o pão" para a minha família
$O$ ver-me dependente dos outros tem-me sido difícil

35- O ver-me dependente dos outros tem-me sido difícil
de suportar

36- Desde que fiquei doente não consigo evitar certos $\quad .60 \quad 94$ comportamento de que não gosto

37- Sinto que pouco posso esperar do futuro $\quad .67 \quad .94$

38- Acho que vou recuperar as minhas forças $\quad-.07 \quad .95$

39- Desde que estou doente tenho sentido muitos medos $\quad .47 \quad .95$

40- Desde que fiquei doente sinto dificuldade em $\quad .76 \quad .94$ encontrar sentido para a minha vida

41- Tenho dores que não me deixam descansar $\quad .40 \quad .95$

42- Tenho esperança de ainda vir a realizar os meus $\quad-.17$ sonhos

43- Desejaria que a minha família não sofresse tanto por $\quad .15 \quad .95$ eu estar doente

44- Penso que vou melhorar

$-.16$

.95

Na tabela 2 podem ser observadas as correlações entre as dimensões do IESSD obtidas na população estudada.

\section{Tabela 2}

Matriz de correlação bivariada de Pearson entre as Dimensões do IESSD obtida na amostra em estudo

\begin{tabular}{|c|c|c|c|c|c|}
\hline Sofrimento & Físico & Psicológico & $\begin{array}{l}\text { Sócio- } \\
\text { relacional }\end{array}$ & Existencial & $\begin{array}{l}\text { Experiências } \\
\text { Positivas }\end{array}$ \\
\hline Físico & - & & & & \\
\hline Psicológico & $.70 * *$ & - & & & \\
\hline Sócio-relacional & $.39 * *$ & $.64 * *$ & - & & \\
\hline Existencial & $.66^{* *}$ & $.84 * *$ & $.69 * *$ & - & \\
\hline Experiências & $-.23^{*}$ & $-.20 *$ & -.05 & -.05 & - \\
\hline Positivas & & & & & \\
\hline
\end{tabular}

O IESSD apresenta-se sob a forma de escala tipo likert de 1 a 5 pontos, em que 1 não corresponde a nada ao que se passa comigo; 2 - corresponde pouco; 3 corresponde bastante; 4 - corresponde muito; 5 - corresponde totalmente ao que se 
passa comigo. Antes da sua aplicação dão-se as seguintes orientações e opções de resposta: "Abaixo encontram-se algumas afirmações que podem corresponder a experiências das pessoas doentes. Por favor indique até que ponto cada uma das afirmações corresponde (ou não) ao que verdadeiramente se passa consigo, marcando com uma cruz o respetivo quadrado tendo em conta a legenda abaixo apresentada. Não há respostas certas ou erradas. É na sua opinião que estamos interessados". A cotação é feita a partir da soma de todas as respostas, sendo interpretada como medida de intensidade da experiência de sofrimento (Gameiro, 1999ª; Gameiro, 1999b; McIntyre \& Gameiro, 1999).

O IESSD continua a ser o único instrumento validado para a população portuguesa (para além dos autores serem nacionais) concebido para avaliar a experiência de sofrimento na doença na perspetiva (subjetiva) do doente, com propriedades psicométricas empiricamente e cientificamente reconhecidas. Trata-se de uma escala bastante utilizada em Portugal com amostras de pessoas doentes (McIntyre, 2004), doentes internados com patologias diversas (Gameiro, 1999), doentes internados em cuidados intensivos (Bento, 2000), pacientes com dor crónica lombar (Araújo-Soares \& McIntyre, 2000), entre outros. Não obstante, não se conhecem referências da sua aplicação em estudos com doentes de cancro da mama. A fundamentação da nossa escolha para utilizar o IESSD no presente trabalho recaiu precisamente na análise desses factos. 


\section{II.1.5.5. Inventário de Sintomas Psicopatológicos (BSI)}

O Inventário de Sintomas Psicopatológicos (BSI) (Canavarro, 1999, 2007) é uma validação para a população portuguesa do Brief Symptom Inventory (BSI) de Derogatis (1975). O BSI na versão original é um questionário de auto-relato concebido para identificar sintomatologia clínica relevante em adolescentes e adultos (Derogatis, 1975). Trata-se de uma versão abreviada do SCL-R-90 (Symptom Check-List) do mesmo autor (Derogatis, 1975), composto por 90 itens, correspondendo cada item a 90 descrições de sintomas psicopatológicos. Contudo, apesar do extenso número de itens avaliar um maior número de dimensões psicopatológicas, implica morosidade no tempo de preenchimento (12 a 20 minutos), constituindo entrave e limitação à sua aplicação em determinados contextos. O BSI surge precisamente com o propósito de mitigar esta desvantagem. Os itens de cada dimensão do BSI foram selecionados a partir dos itens com maior carga fatorial de cada dimensão do SCL-R-90. As correlações encontradas para as nove dimensões psicopatológicas entre o BSI e o SCL-R-90 variam entre $.31 \mathrm{e}$ .72, indicando, na opinião do autor, que ambos os instrumentos medem o mesmo constructo na população clínica (Derogatis, 1993).

O BSI é constituído por 53 itens organizados em nove dimensões de sintomas: Somatização, Obsessão-Compulsão, Sensibilidade Interpessoal, Depressão, Ansiedade, Hostilidade, Ansiedade Fóbica, Ideação Paranóide e Psicoticismo, e três índices globais de distress: Índice Global de Severidade (GSI), Índice de Sintomas Positivos de 


\section{Distress (PSDI) e Total de Sintomas Positivos (PST) (Derogatis, 1975). Os índices}

globais de sintomas medem o nível de sintomatologia atual ou passada, a intensidade de sintomas, e o número de sintomas relatados, respetivamente. As nove dimensões psicopatológicas são no seu conjunto indicadores importantes de psicopatologia, seguindo os critérios de classificação diagnóstica das cinco primeiras categorias da CID-10 (F00 a F49) e das perturbações do Eixo I da DSM-IV (Derogatis, 1975, 1993).

No quadro 3 encontram-se descritas cada uma das nove dimensões psicopatológicas, índices globais e os itens correspondentes.

\section{Quadro 3}

Descrição das dimensões psicopatológicas do BSI e itens correspondentes

\begin{tabular}{|c|c|}
\hline Dimensões & Itens \\
\hline \multicolumn{2}{|l|}{ Somatização } \\
\hline $\begin{array}{l}\text { Reflete o mal-estar resultante da perceção do funcionamento somático, queixas } \\
\text { cardiovasculares, respiratórias, gastrointestinais, bem como, outros controlados pelo } \\
\text { sistema autonómico. Dores musculares e outros equivalentes somáticos de } \\
\text { ansiedade. } \\
\text { Obsessão-Compulsão }\end{array}$ & $2,7,23,29,30,33,37$ \\
\hline $\begin{array}{l}\text { Sintomas identificados como sintoma clínico com o mesmo nome. Inclui cognição, } \\
\text { impulsos e comportamentos que são percecionados como persistentes e recorrentes } \\
\text { que o indivíduo não consegue controlar. Incluem-se nesta dimensão comportamentos } \\
\text { que indicam dificuldade cognitiva geral. }\end{array}$ & $5,15,26,27,32,36$ \\
\hline \multicolumn{2}{|l|}{ Sensibilidade Interpessoal } \\
\hline $\begin{array}{l}\text { Centra-se nos sentimentos de inadequação pessoal, inferioridade, nomeadamente, na } \\
\text { comparação com outras pessoas. São características desta dimensão a auto- } \\
\text { depreciação, a hesitação, o desconforto e timidez durante as interações sociais. } \\
\text { Depressãa }\end{array}$ & $20,21,22,42$ \\
\hline $\begin{array}{l}\text { Esta dimensão inclui um grande número de indicadores de depressão clínica. } \\
\text { Sintomas como afeto e humor disfórico, perda de energia vital, falta de motivação e } \\
\text { de interesse pela vida. }\end{array}$ & $9,16,17,18,35,50$ \\
\hline \multicolumn{2}{|l|}{ Ansiedade } \\
\hline $\begin{array}{l}\text { São indicadores desta dimensão o nervosismo e a tensão. Sintomas de ansiedade } \\
\text { generalizada e ataques de pânico. Componentes cognitivas relacionadas com a } \\
\text { apreensão e alguns correlatos somáticos de ansiedade. } \\
\text { Hostilidade }\end{array}$ & $1,12,19,38,45,49$ \\
\hline $\begin{array}{l}\text { Inclui pensamentos, emoções e comportamentos característicos do estado afetivo } \\
\text { negativo de cólera. }\end{array}$ & $6,13,40,41,46$ \\
\hline \multicolumn{2}{|l|}{ Ansiedade Fóbica } \\
\hline $\begin{array}{l}\text { Os itens desta dimensão centram-se nas manifestações do comportamento fóbico } \\
\text { mais patognomónicas e disruptivas, caracterizadas pelo medo persistente, irracional } \\
\text { e desproporcionado relativamente a uma pessoa, local ou situação específica, } \\
\text { correspondente a comportamento de evitamento. }\end{array}$ & $8,28,31,43,47$ \\
\hline \multicolumn{2}{|l|}{$\begin{array}{l}\text { Esta dimensão incide na perturbação do funcionamento cognitivo. O pensamento } \\
\text { projetivo, hostilidade, suspeição, grandiosidade, egocentrismo, medo da perda de } \\
\text { autonomia e delírios, são exemplos desta perturbação. }\end{array}$} \\
\hline $\begin{array}{l}\text { Psicoticismo } \\
\text { Integra indicadores de isolamento e de estilo de vida esquizoide, sintomas primários } \\
\text { de esquizofrenia como alucinações e controlo de pensamento. A escala organiza-se } \\
\text { progressivamente do isolamento pessoal ligeiro à evidência de psicose. } \\
\text { Índice Global de Severidade (GSI) }\end{array}$ & $3,14,34,44,53$ \\
\hline Indica a intensidade do mal-estar experienciado pelos respondentes. & $11,25,39,52$ \\
\hline \multicolumn{2}{|l|}{ Total de Sintomas Positivos (PST) } \\
\hline \multicolumn{2}{|l|}{$\begin{array}{l}\text { Representa o número de queixas sintomáticas apresentadas pelos respondentes. } \\
\text { Índice de Sintomas Positivos de Distress (PSDI) }\end{array}$} \\
\hline Indica a média da intensidade de todos os sintomas assinalados. & \\
\hline $\begin{array}{l}\text { Assim, o indivíduo pode ter um PSDI baixo, indicando fraca intensidade dos } \\
\text { sintomas, mas ter um PST elevado, ou seja, apresentando muita sintomatologia } \\
\text { psicopatológica. }\end{array}$ & \\
\hline
\end{tabular}


Na validação do BSI para a população portuguesa efetuada por Canavarro (1999, 2007), a tradução dos três índices sofreu adaptações, assim na versão da autora o Índice Global de Severidade (GSI) designa-se Índice Geral de Sintomas (IGS), e o Índice de Sintomas Positivos de Distress (PSDI) de Índice de Sintomas Positivos (ISP). A designação do Total de Sintomas Positivos (PST) manteve-se, apenas a sigla sofreu alterações em funções da tradução, passou a ser TSP. No processo de aferição foram utilizadas duas amostras, uma constituída por indivíduos da população em geral, e outra por indivíduos emocionalmente perturbados. A amostra 1, constituída por 404 indivíduos (114 homens e 290 mulheres), na sua maioria casados, com habilitações académicas do ensino secundário ou curso médio, pertencentes às categorias socioeconómicas 5 e 9 (quadros de direção, técnicos e científicos, artísticos e similares e não ativos, respetivamente). A amostra 2, foi constituída por 147 indivíduos (56 homens e 91 mulheres) que recorreram aos Serviços da Clínica Psiquiátrica dos Hospitais da Universidade de Coimbra entre Janeiro de 1995 e Maio de 1996. A maioria dos participantes da amostra eram solteiros ou casados, possuíam a escolaridade obrigatória e pertenciam às categorias socio-económicas 7 e 9 (trabalhadores por conta de outrem no comércio, nos serviços da administração pública e não ativos, respetivamente).

No que às propriedades psicométricas diz respeito, os estudos de consistência interna do BSI indicaram correlações que variam entre .29 e .79 entre cada item e a o item total. Sendo o valor mais baixo verificado no item 43. Os valores de alfa de cronbach das nove escalas situam-se entre os .62 e .80 (Canavarro, 1999, 2007). Na tabela 3 podem ser consultados os valores de alfa obtidos nas nove dimensões. 
Tabela 3

Consistência interna: valores globais para as nove escalas

\begin{tabular}{lc}
\hline \multicolumn{1}{c}{ Escala } & Alfa \\
\hline Somatização & .80 \\
Obsessões-Compulsões & .77 \\
Sensibilidade-Interpessoal & .76 \\
Depressão & .73 \\
Ansiedade & .77 \\
Hostilidade & .76 \\
Ansiedade Fóbica & .62 \\
Ideação Paranóide & .72 \\
Psicoticismo & .62 \\
\hline
\end{tabular}

As correlações entre dimensões revelaram-se estatisticamente significativas ( $p<.001)$ (Canavarro, 1999, 2007). Os resultados das correlações encontram-se na tabela 4.

Tabela 4

Matriz de correlações entre as dimensões do BSI

\begin{tabular}{|c|c|c|c|c|c|c|c|c|c|c|c|}
\hline & SOM & OC & SI & DEP & ANS & HOS & $\mathbf{A F}$ & IP & PSI & IGS & ISP \\
\hline \multicolumn{12}{|l|}{ Somatização } \\
\hline Obsessões- & .46 & & & & & & & & & & \\
\hline \multicolumn{12}{|l|}{ Compulsões } \\
\hline Sensibilidade- & .40 & .58 & & & & & & & & & \\
\hline \multicolumn{12}{|l|}{ Inperpessoal } \\
\hline Depressão & .38 & .55 & .64 & & & & & & & & \\
\hline Ansiedade & .54 & .61 & .61 & .58 & & & & & & & \\
\hline Hostilidade & .46 & .57 & .61 & .54 & .61 & & & & & & \\
\hline Ansiedade & .46 & .42 & .44 & .40 & .54 & .47 & & & & & \\
\hline \multicolumn{12}{|l|}{ Fóbica } \\
\hline Ideação & .49 & .45 & .61 & .48 & .53 & .57 & .42 & & & & \\
\hline \multicolumn{12}{|l|}{ Paranóide } \\
\hline Psicotiscismo & .46 & .58 & .68 & .73 & .62 & .61 & .48 & .55 & & & \\
\hline$I G S$ & .69 & .77 & .80 & .78 & .82 & .78 & .66 & .73 & .82 & & \\
\hline$I S P$ & .47 & .61 & .57 & .70 & .64 & .57 & .52 & .54 & .62 & .76 & \\
\hline$T S P$ & .65 & .70 & .74 & .66 & .72 & .72 & .58 & .68 & .74 & .91 & .47 \\
\hline
\end{tabular}

Nota: $\mathrm{SOM}=$ Somatização $; \mathrm{OC}=$ Obsessões-Compulsões; $\mathrm{SI}=$ Sensibilidade Interpessoal $; \mathrm{DEP}=$ Depressão $;$ ANS= Ansiedade; $\mathrm{HOS}=$ Hostilidade $; \mathrm{AF}=$ Ansiedade Fóbica $; \mathrm{IP}=$ Ideação Paranóide $; \mathrm{PSI}=$ Psicoticismo $; \mathrm{ISP}=$ Índice de Sintomas Positivos

O Instrumento revela ainda boas potencialidades em termos de validade discriminativa, como podemos constatar pelos resultados apresentados na tabela 5 . 


\section{Tabela 5}

Análise da função discriminante entre indivíduos emocionalmente perturbados $e$ indivíduos da população em geral

\begin{tabular}{lcc}
\multicolumn{1}{c}{ Variável } & $\boldsymbol{F}$ & $\boldsymbol{P}$ \\
\hline Somatização & 615.910 & .000 \\
Obsessões-Compulsões & 1283.151 & .000 \\
Sensibilidade Inperpessoal & 644.575 & .000 \\
Depressão & 1020.631 & .000 \\
Ansiedade & 1104.643 & .000 \\
Hostilidade & 687.032 & .000 \\
Ansiedade Fóbica & 384.383 & .000 \\
Ideação Paranóide & 885.578 & .000 \\
Psicoticismo & 899.136 & .000 \\
IGS & 125.829 & .000 \\
TSP & 81.592 & .000 \\
ISP & 160.376 & .000 \\
Lambada de Wilks=.171 & \multicolumn{2}{c}{$F=216.654$} \\
C.L.=12.537 & \multicolumn{2}{c}{$p=.000$} \\
\hline \multicolumn{2}{c}{} \\
\hline
\end{tabular}

Segundo Canavarro (1999, 2007) o BSI pode ser utilizado em doentes psiquiátricos, indivíduos perturbados emocionalmente, indivíduos com qualquer outra doença e pessoas da população em geral. No caso dos adolescentes, não é recomendável a administração a menores de 13 anos de idade.

Os itens encontram-se organizados numa escala likert de 0 a 4, 0 não se aplica a mim, 4 aplica-se muito. O tempo de resposta ao questionário situa-se entre os 08 a 12 minutos.

No que respeita à cotação, as pontuações das nove dimensões são obtidas através da soma dos valores respondidos a cada item (0-4), pertencentes a cada uma das dimensões. O resultado da soma deverá ser seguidamente dividido pelo número de itens correspondente à dimensão respetiva. O Cálculo dos três índices obedece às seguintes fórmulas:

Índice Geral de Severidade (GSI) - é calculado através da soma dos itens das nove dimensões psicopatológicas + os quatro itens que não pertencem a nenhuma delas e divide-se pelo número total de itens (53). 
Total de Sintomas Positivos (TSP) - calcula-se a partir da soma dos itens das respostas "não-zero".

Índice de Sintomas Positivos (ISP) - obtém-se dividindo o somatório de todos os itens pelo TSP.

Segundo a autora, a interpretação das pontuações permite fazer uma triagem dos quadros sintomáticos clinicamente significativos, permitindo avaliar a intensidade do mal-estar psicológico, variando entre pouco ou nenhum significado clínico até ao malestar mórbido, característico de transtorno psicológico. Acrescenta ainda, que a simples leitura dos índices globais permite avaliar, de uma forma geral, a intensidade da sintomatologia avaliada. Segundo os resultados obtidos na aferição, dos três índices, o que melhor discrimina os sujeitos que têm patologia é o ISP. Assim, pontuações no BSI $\geq 1.7$ correspondem provavelmente a pessoas com perturbações emocionais.

Com o objetivo de testarmos as potencialidades psicométricas do BSI na amostra estudada, foi realizada uma análise de consistência interna do instrumento. Obtiveramse valores um pouco mais baixos comparativamente aos da autora nas correlações entre cada item e nota global, variáveis entre .30 e .72. Correspondendo o valor mais baixo ao item 02 (.30). A descrição pormenorizado da análise efetuada pode ser consultada na tabela 6 . 


\section{Tabela 6}

Estatística de distribuição dos itens e coeficientes de consistência interna de Cronbach do BSI

\begin{tabular}{|c|c|c|}
\hline \multirow[b]{2}{*}{ Itens } & \multicolumn{2}{|c|}{$N=104$} \\
\hline & $\begin{array}{c}\text { Correlação } \\
\text { item-total } \\
\text { corrigido }\end{array}$ & $\begin{array}{c}\text { Alfa } \\
\text { Cronbach se o } \\
\text { item for } \\
\text { eliminado } \\
\end{array}$ \\
\hline 01- Nervosismo ou tensão interior & .49 & .95 \\
\hline 02- Desmaios ou tonturas & .30 & .95 \\
\hline $\begin{array}{l}\text { 03- Ter a ideia que as outras pessoas podem controlar os } \\
\text { meus pensamentos }\end{array}$ & .40 & .95 \\
\hline $\begin{array}{l}\text { 04- Terá a ideia que os outros são culpados pela maioria dos } \\
\text { meus problemas }\end{array}$ & .37 & .95 \\
\hline 05- Dificuldade em se lembrar de coisas passadas ou recentes & .49 & .95 \\
\hline 06- Aborrecer-se ou irritar-se facilmente & .60 & .95 \\
\hline 07- Dores sobre o coração ou no peito & .34 & .95 \\
\hline 08- Medo na rua ou praça pública & .45 & .95 \\
\hline 09- Pensamento em acabar com a vida & .35 & .95 \\
\hline 10- Sentir que não pode confiar na maioria das pessoas & .52 & .95 \\
\hline 11- Perder o apetite & .32 & .95 \\
\hline 12- Ter um medo súbito sem razão para isso & .59 & .95 \\
\hline 13- Ter impulsos que não se podem controlar & .58 & .95 \\
\hline 14- Sentir-se sozinha mesmo quando está com mais pessoas & .60 & .95 \\
\hline 15- Dificuldades em fazer qualquer trabalho & .53 & .95 \\
\hline 16- Sentir-se sozinho & .63 & .95 \\
\hline 17- Sentir-se triste & .71 & .95 \\
\hline 18- Não ter interesse por nada & .69 & .94 \\
\hline 19- Sentir-se atemorizado & .57 & .95 \\
\hline 20- Sentir-se facilmente ofendido nos seus sentimentos & .55 & .95 \\
\hline $\begin{array}{l}\text { 21- Sentir que as outras pessoas não são suas amigas ou não } \\
\text { gostam de si }\end{array}$ & .54 & .95 \\
\hline 22- Sentir-se inferior aos outros & .57 & .95 \\
\hline 23- Vontade de vomitar ou mal do estômago & .38 & .95 \\
\hline $\begin{array}{l}\text { 24- Impressão de que os outros o costumam observar ou falar } \\
\text { de si }\end{array}$ & .47 & .95 \\
\hline 25- Dificuldade em adormecer & .37 & .95 \\
\hline 26- Sentir necessidade de verificar várias vezes o que faz. & .48 & .95 \\
\hline 27- Dificuldade em tomar decisões & .51 & .95 \\
\hline 28- Medo de viajar de autocarro, de comboio ou de metro & .30 & .95 \\
\hline 29- Sensação de falta de ar & .41 & .95 \\
\hline 30- Calafrios ou afrontamentos & .39 & .95 \\
\hline $\begin{array}{l}\text { 31- Ter de evitar certas coisa, lugares ou atividades por lhe } \\
\text { causarem medo }\end{array}$ & .43 & .95 \\
\hline 32- Sensação de vazio na cabeça & .72 & .94 \\
\hline $\begin{array}{l}\text { 33- Sensação de anestesia (encortiçamento ou formigueiro) } \\
\text { no corpo }\end{array}$ & .47 & .95 \\
\hline 34- Ter a ideia que deveria ser castigada pelos seus pecados & .40 & .95 \\
\hline 35- Sentir-se sem esperança para o futuro & .63 & .94 \\
\hline 36- Ter dificuldade em se concentrar & .54 & .95 \\
\hline 37- Falta de forças em partes do corpo & .52 & .95 \\
\hline 38- Sentir-se em estado de aflição ou tensão & .66 & .94 \\
\hline 39- Pensamentos sobre a morte ou que vai morrer & .56 & ,95 \\
\hline 40- Ter impulsos de bater, ofender ou ferir alguém & .26 & .95 \\
\hline 41- Ter vontade de destruir ou partir coisas & .38 & .95 \\
\hline 42- Sentir-se embaraçado junto de outras pessoas & .50 & .95 \\
\hline 43- Sentir-se mal no meio das multidões como lojas, cinemas & .31 & .95 \\
\hline
\end{tabular}


ou assembleias 44- Grande dificuldade em sentir-se "próximo" de outra
pessoa

45- Ter ataques de terror ou pânico

46- Entrar facilmente em discussão $\quad .22 \quad .95$

47- Sentir-se nervoso quando tem de ficar sozinho $\quad .56 \quad .95$

48- Sentir que outras pessoas não dão valor ao seu trabalho $\quad .51 \quad .95$ ou às suas capacidades

49- Sentir-se desassossegado que não consegue manter-se $\quad .58 \quad .95$ sentado ou quieto

50- Sentir que não tem valor

51- A impressão de que, se deixasse, as outras pessoas se $\quad .37 \quad .95$ aproveitariam de si

52- Ter sentimentos de culpa $\quad .53 \quad .95$

53- Ter a impressão de que alguma coisa não regula bem na $\quad .57 \quad .95$ sua cabeça

O BSI tem sido utilizado em muitos estudos no âmbito da saúde/doença. A nível nacional destacamos trabalhos com amostras de doentes com fibromialgia (Quartilho, 1999), com grupos de mães de filhos com paralesia cerebral (Monteiro, Matos \& Coelho, 2004), com mães e pais de bebés prematuros (Pedrosa, Canavarro, Oliveira, Moura-Ramos \& Pereira, 2004), e com mulheres com cancro da mama (Patrão, Maroco \& Leal, 2006). A nível internacional, também existem registos da sua utilização na versão original (Derogatis, 1975), igualmente nos contextos de saúde/doença, ressaltamos especificamente, alguns dos que envolveram doentes com cancro da mama (Gilbar, 1997; Harbor, Sumar, Rummans, et al, 2002; Northouse, 1989). Assim, tendo em conta as propriedades psicométricas demonstradas e a longevidade da sua aplicação em estudos no contexto da doença, considerámos o BSI uma boa escolha para avaliar as avariáveis em estudo na amostra de doentes com cancro da mama.

\section{II.1.6. Procedimentos}

Todos os procedimentos realizados ao longo do presente trabalho tiveram em consideração os pressupostos éticos subjacentes à prática investigativa, em geral, e à investigação em psicologia da saúde, em particular. A recolha dos dados pautou-se 
sempre pelo respeito e salvaguarda da integridade física e psicológica dos doentes que participaram no estudo.

O primeiro procedimento do nosso estudo consistiu no pedido de autorização ao Conselho de Administração do Centro Hospitalar de Trás-os-Montes e Alto Douro para a realização do trabalho. Para tal, foi enviado o plano de investigação com os objetivos do estudo e respetiva metodologia. Concedida a autorização por parte do Conselho de Administração e do Diretor do Centro de Oncologia da referida Unidade Hospitalar, foi solicitada a colaboração do diretor do Centro de Oncologia, no sentido de indicar e apresentar os Serviços onde seriam recolhidos os dados.

A recolha de dados efetuou-se na Consulta da Mama de Seguimento em Ambulatório, no Serviço de Quimioterapia e de Radioterapia. A recolha processou-se sempre em articulação com a responsável pelos três serviços, durante os períodos de espera da consulta e tratamento. Os questionários foram respondidos por heteroaplicação, numa sala disponibilizada pelos serviços para o efeito, assegurando a privacidade das participantes.

Num primeiro momento, procedeu-se à apresentação do investigador, da investigação e do contexto em que integra. Em seguida, solicitou-se a assinatura do consentimento informado, no qual se apresentou a informação relativa aos objetivos da investigação, papel dos participantes e do investigador. Garantiu-se a cada participante o anonimato e a confidencialidade dos dados, assegurando que os mesmos se destinam exclusivamente para efeitos de investigação.

Depois de assinado o consentimento informado, prosseguiu-se com a heteroaplicação dos instrumentos de avaliação, pela seguinte ordem: Questionário de Dados Sociodemográficos, Inventário de Experiências Subjetivas de Sofrimento na Doença 
(IESSD), Inventário de Sintomas Psicológicos (BSI), por último, o Questionário da História da Doença Oncológica foi entregue ao médico oncologista de cada uma das participantes. Durante a aplicação dos instrumentos foi sempre assegurada a compreensão das questões por parte dos participantes, procedendo-se à sua reformulação, sempre que necessário.

A metodologia de recolha dos dados possibilitou o levantamento de informação complementar à levantada por questionários. Permitindo conhecer qualitativamente o significado da experiência de cancro da mama. Com esse propósito, as partilhas das doentes em formato de narrativa, foram registadas em diário de campo.

Depois de recolhidos, os dados foram introduzidos numa base de dados em SPSS (statistical package for social sciences - versão 13.0), construída para o efeito. Seguidamente foram realizados os procedimentos estatísticos com recurso ao mesmo programa, com o objetivo de testar as hipóteses de estudo formuladas. A análise estatística sustentou-se em duas principais metodologias: descritiva e correlacional.

Recorreu-se à análise descritiva de distribuição, frequências e desvio padrão com o intuito de caracterizar a amostra do ponto de vista sociodemográfico e clínico e a avaliar as variáveis empíricas em estudo, experiência subjetiva de sofrimento na doença e sintomatologia psicopatológica. A análise correlacional foi utilizada com o propósito de estudar a relação entre as variáveis empíricas e entre estas e as restantes variáveis.

Em ordem a observar se a experiência de sofrimento na doença $(\mathrm{H} 2 ; \mathrm{H} 3)$ e a sintomatologia psicopatológica $(\mathrm{H} 5 ; \mathrm{H} 6)$ eram influenciadas em termos de variabilidade pelas variáveis sociodemográficas e clínicas, realizou-se uma análise de variância multivariada (MANOVA), utilizando-se o teste- $t$ para amostras emparelhadas. Por forma a garantir a credibilidade dos efeitos estudados foram efetuados testes post-hoc, 
optando-se pelo critério de scheffé (Scheffé, 1953), por ser considerado um teste conservador (Tabachinick \& Fidell, 1996). O poder das associações das variáveis foi registado com base nos cálculos dos valores do eta-quadrado. Como critério de significância recorreu-se ao qui-quadrado $\left(x^{2}\right)$ a $5 \%(p \leq .05)$.

A pesquisa de possível relação entre a experiência subjetiva de sofrimento na doença e a sintomatologia psicopatológica foi realizada através de análise correlacional bivariada entre todas as dimensões das duas variáveis. Seguiu-se o mesmo critério de significância assinalado acima.

Foram ainda realizadas regressões múltiplas stander tendo como propósito investigar se o sofrimento na doença contribui para o agravamento da severidade da sintomatologia psicopatológica (H7).

Por último, com o obejtivo de traçar um perfil psicológico das doentes com cancro da mama em função das variáveis empíricas em estudo (H8), precedeu-se à construção de clusters de severidade, quer para a experiência de sofrimento na doença, quer para a sintomatologia psicopatológica. A análise dos clusters apoiou-se no método combinatório, especificando os centróides a partir do método hierárquico (ward`s method e squared euclidean distance). Seguidamente foi aplicado o método não hierárquico (K-means clusters analysis). Os três padrões de severidade (baixa, média e levada) foram avaliados através da realização de análises de regressão univariadas (ANOVAS).

Todos os resultados dos procedimentos estatísticos efetuados serão apresentados no próximo capítulo. 


\section{II.2. RESULTADOS}

\section{II.2.1. Variáveis Sociodemográficas}

\section{II.2.1.1. Idade}

As doentes participantes do estudo têm uma idade compreendida entre os 29 e os 82 anos de idade $(M=55.22 ; D P=13.07)$. Como podemos observar na tabela 1 , a amostra distribui-se por quatro grupos de idades, o maior número 41 (39.42\%) das participantes situam-se na faixa etária dos 61 aos 75 anos de idade, e em igual percentagem 30 (28.85\%) nos grupos etários dos 46 aos 60 e dos 20 aos 45 anos de idade. Um número restrito de participantes 3 (2.88\%) situam-se no grupo maiores de 75 anos.

\section{Gráfico 1}

Distribuição da amostra por grupos de idades

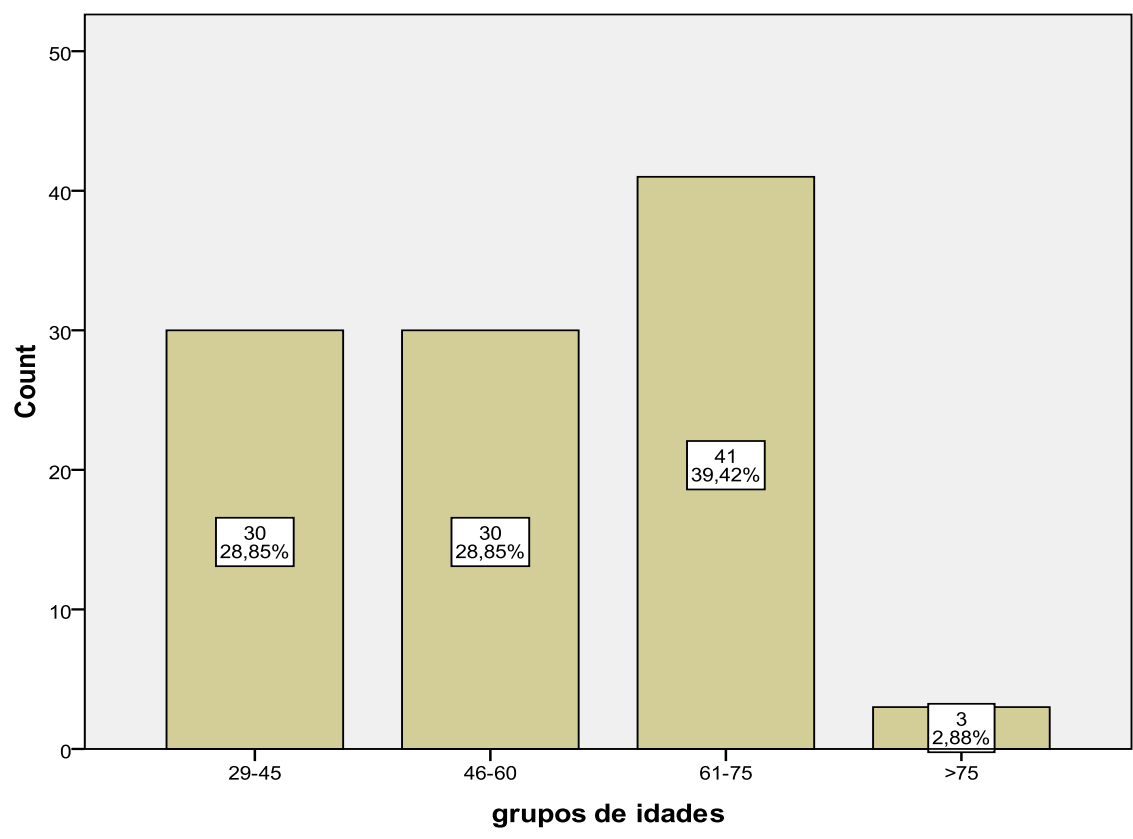




\section{II.2.1.2. Concelho de residência}

Como podemos observar no gráfico 2 , a generalidade das doentes reside no Concelho de Vila Real 46 (44.23\%), 20 (19.31\%) noutros Concelhos pertencentes ao Distrito de Vila Real (Valpaços, Peso da Régua, Vila Pouca de Aguiar, Sabrosa, Alijó), e 38 (36.5\%) em Concelhos pertencentes aos distritos de Bragança (Macedo de Cavaleiros, entre outros) e Viseu (Lamego).

\section{Gráfico 2}

Frequências e Percentagens relativas ao Concelho de residência

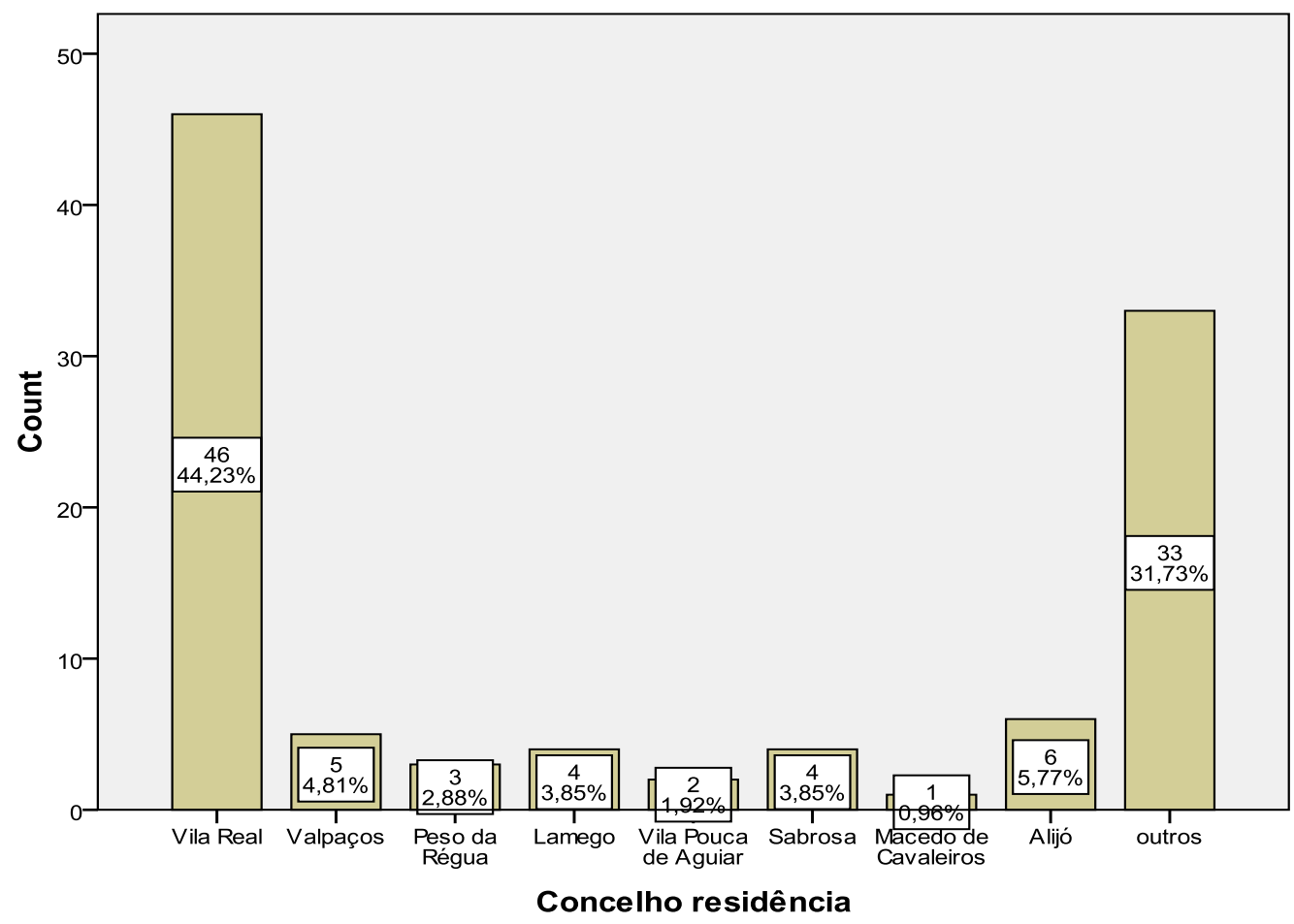

\section{II.2.1.3. Estado civil}

A generalidade das doentes participantes são casadas 71 (68.3\%), 15 (14.4\%) são viúvas, $9(8.7 \%)$ separadas/divorciadas, 8 (7.7\%) solteiras e apenas uma (1\%) vive em união de facto. 


\section{II.2.1.4. Escolaridade}

O nível de escolaridade de cerca de metade das doentes da amostra (41.34\%) é o $1^{\circ}$ ciclo do ensino básico, ainda que em percentagem equivalente umas o tenham completado (20.19\%) e outras não $(21.15 \%)$. A outra metade distribui-se pelo $3^{\circ}$ ciclo (14.46\%), ensino superior (13.46\%) e secundário (12.50\%).

\section{Gráfico 3}

Frequências e Percentagens relativas à Escolaridade

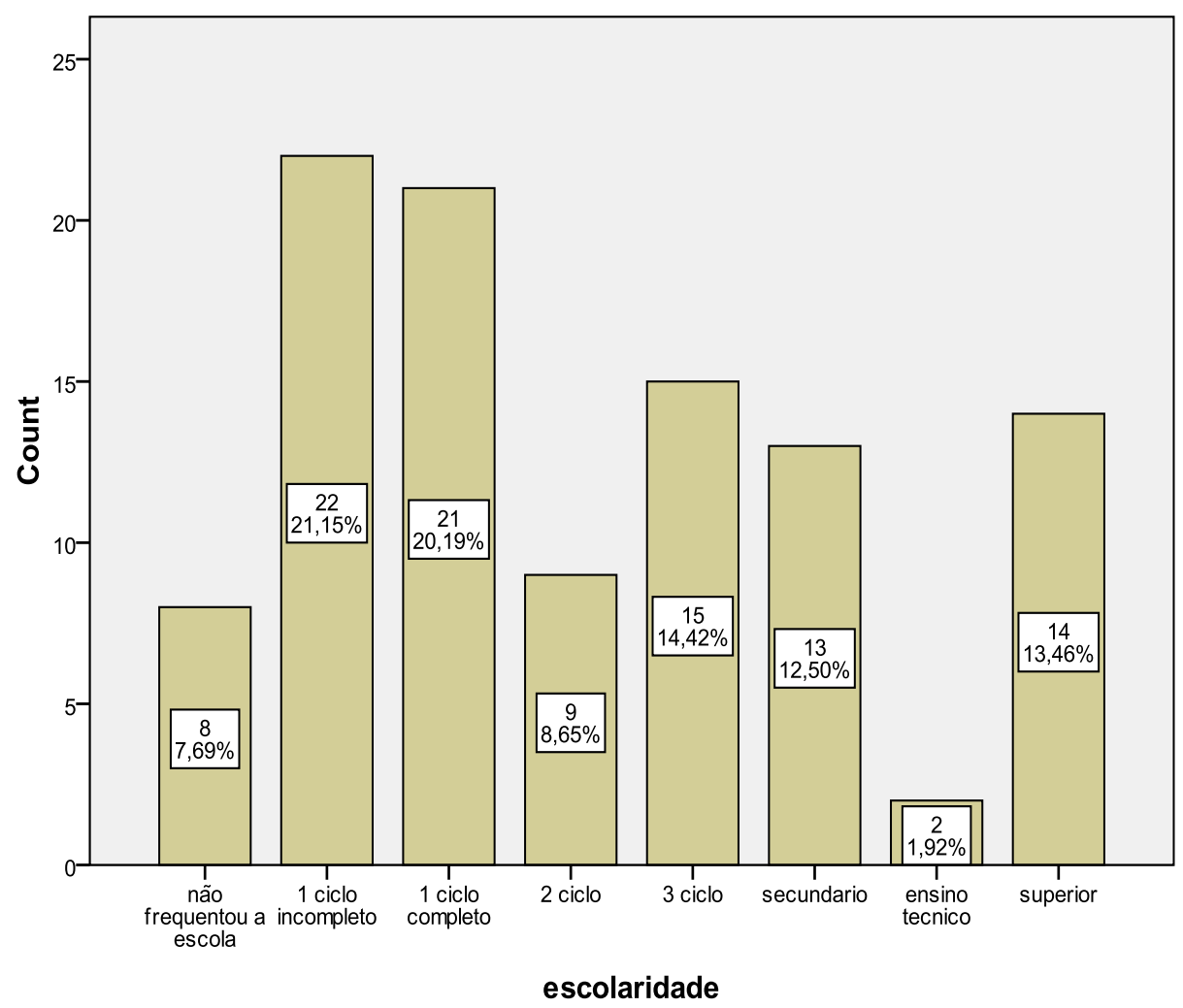

\section{II.2.1.5. Profissão}

Profissionalmente, aproximadamente metade das participantes $(41.75 \%)$ são domésticas. Seguindo-se outras profissões (profissões auxiliares: de educação, 
administrativas, cozinha, entre outras) (23.30\%). Agricultoras numa representatividade de $14.58 \%$ e $9.71 \%$ professoras.

\section{Gráfico 4}

Frequências e Percentagens relativas à Profissão

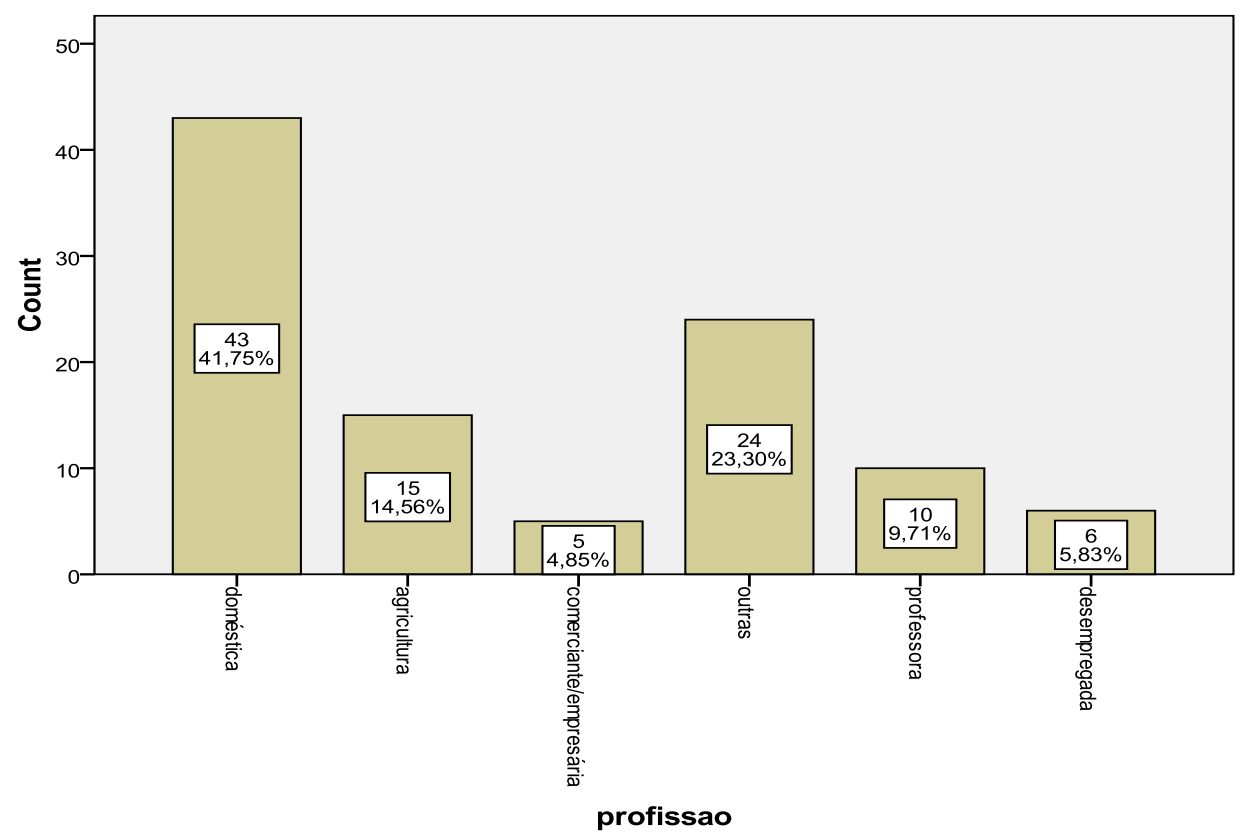

\section{II.2.1.6. Situação ocupacional}

A maioria (54.71\%) das doentes participantes no estudo encontram-se a nível ocupacional pouco ativas, sendo que, $35.58 \%$ são reformadas e $19.23 \%$ estão de baixa/atestado médico. Apenas $16.35 \%$ mantém as suas atividades domésticas e $12.50 \%$ exercem ativamente a suas profissões. 


\section{Gráfico 5}

Frequências e Percentagens relativas à Situação Ocupacional

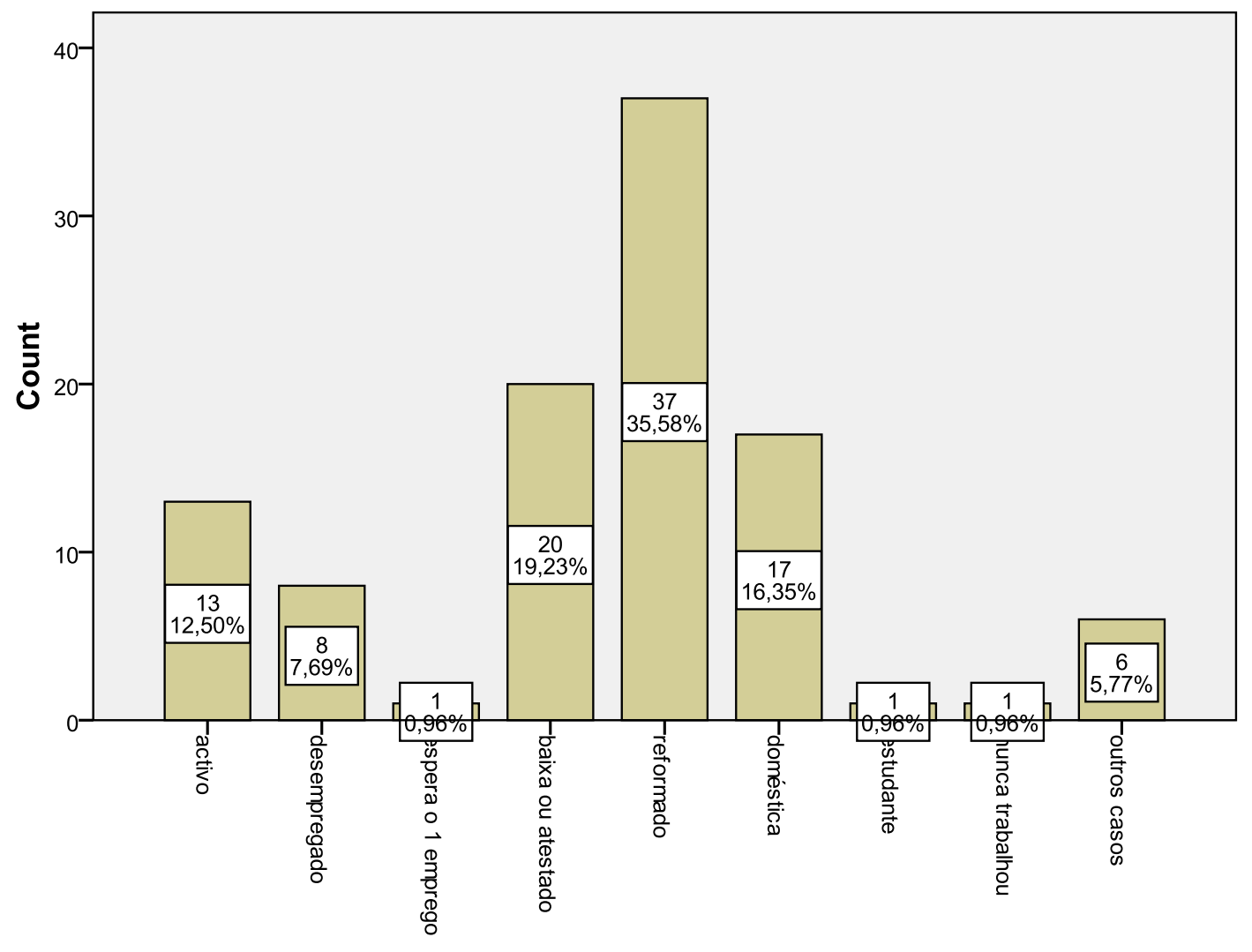

Situacao ocupacional

\section{II.2.1.7. Agregado Familiar}

O agregado familiar da generalidade das doentes (65.39\%) é constituído pelos cônjuges, sendo que, $42.31 \%$ vivem com o cônjuge e filhos, $5.77 \%$ com os cônjuges, filhos, pais ou sogros e $17.31 \%$ apenas com os primeiros. Vivem sozinhas $13.5 \%$ das doentes. 


\section{Gráfico 6}

Frequências e Percentagens relativas à Composição do Agregado Familiar

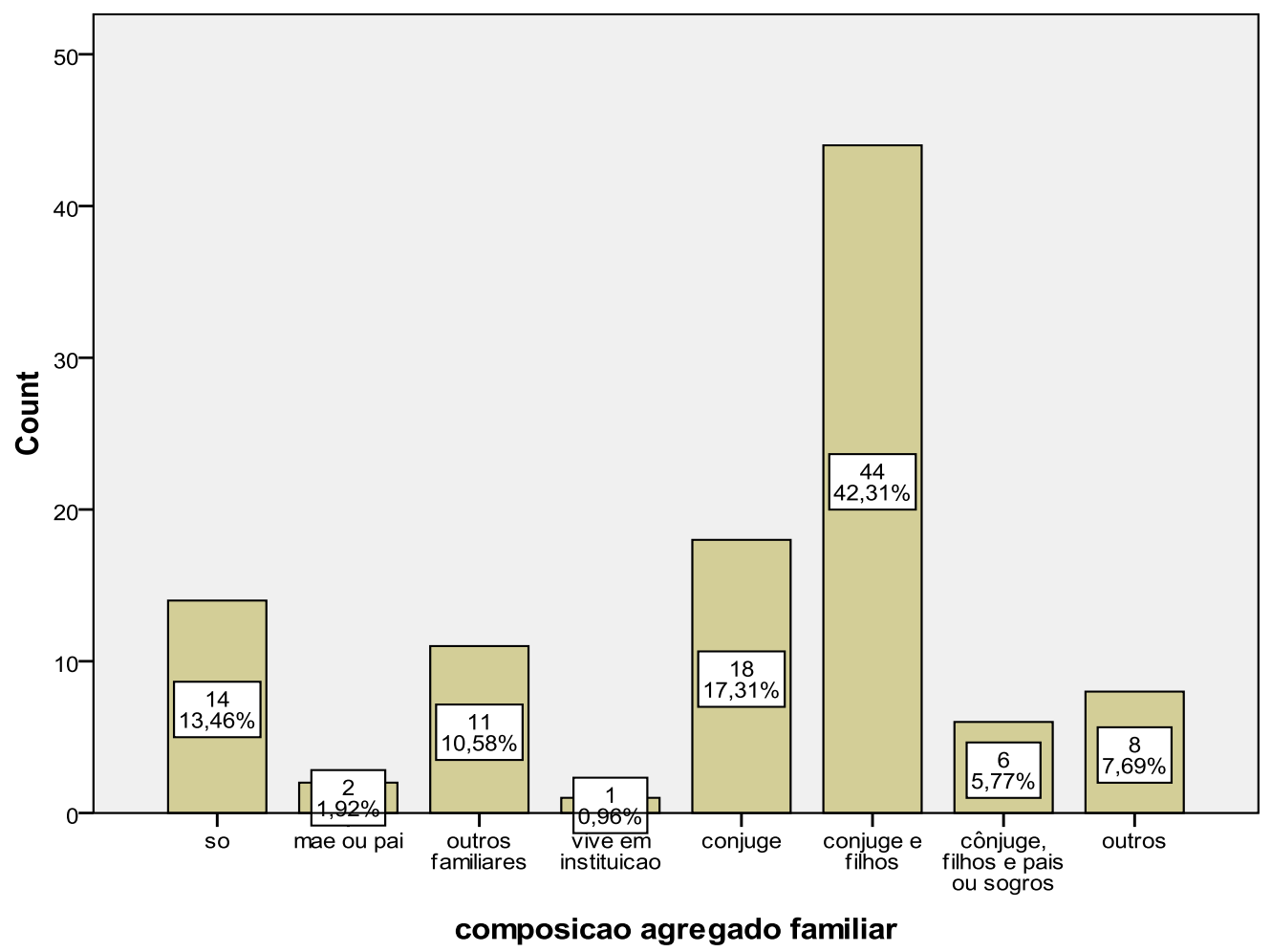

\section{2.2. Variáveis Clínicas}

Antes da descrição dos resultados referentes às variáveis clínicas, importa sublinhar a inexistência de alguns dados relativamente às mesmas, dado que não foram preenchidos pelos clínicos.

\section{II.2.2.1. Diagnóstico}

As doentes participantes do estudo encontram-se em diferentes fases do curso/trajetória da doença. Registam-se em maior número as doentes em fase de sobrevivência, ou seja, diagnosticadas há mais de dois anos (34.31\%), encontrando-se em seguimento periódico em consultas de follow up. Cerca de $28.43 \%$ receberam o diagnóstico há menos de seis meses, encontrando-se nas fases de diagnóstico e início 
dos tratamentos. Encontram-se no grupo das recentemente diagnosticadas $23.53 \%$ das doentes (diagnóstico há menos de um ano). Em menor percentagem (13.73\%) encontram-se as doentes em fase de tratamentos (meio e final do tratamento).

\section{Gráfico 7}

Frequências e Percentagens relativas ao Tempo de Diagnóstico

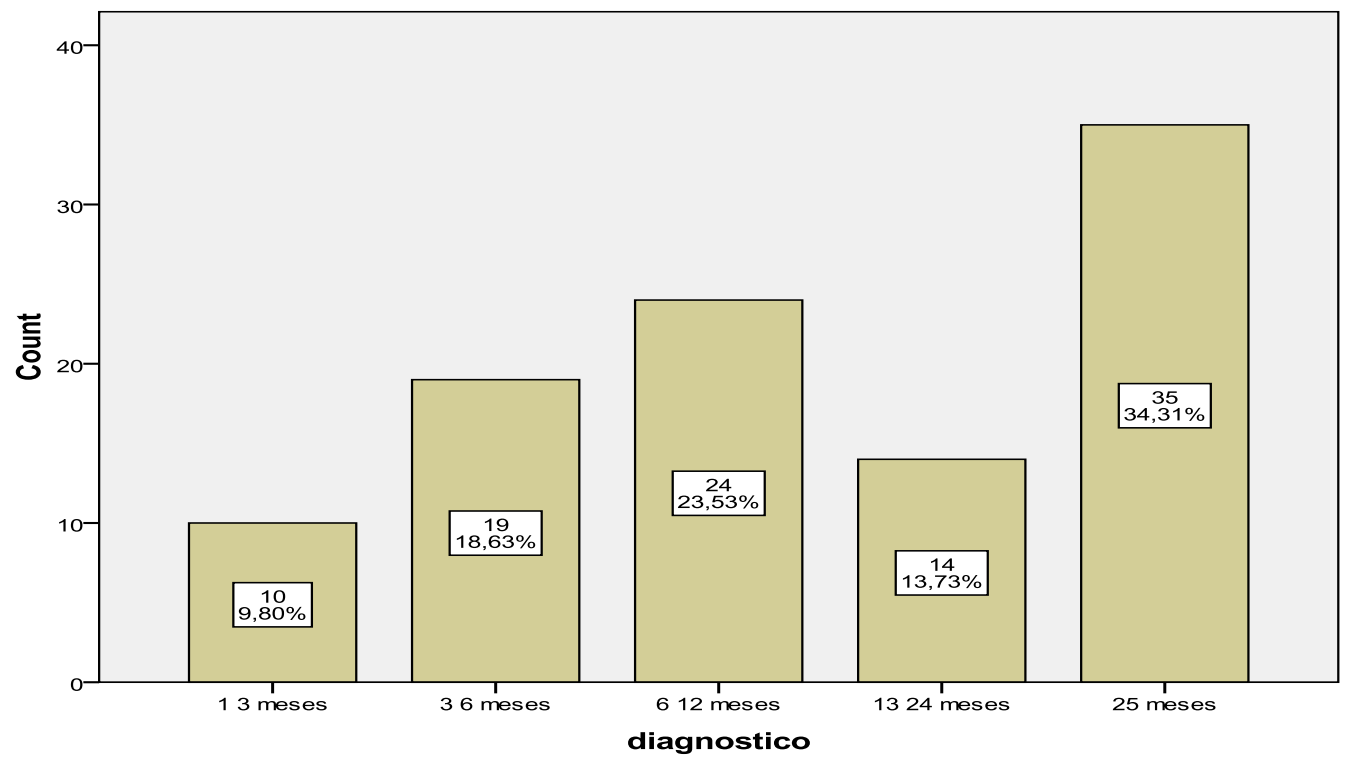

\section{II.2.2.2. Estadio da doença}

No que respeita ao estadio de evolução da doença, em metade das doentes (50.52\%) o tumor encontra-se a nível loco-regional. Na outra metade, verifica-se a nível local e metastático em igual percentagem (24.74\%). 


\section{Gráfico 8}

Frequências e Percentagens relativas ao Estadio do Tumor

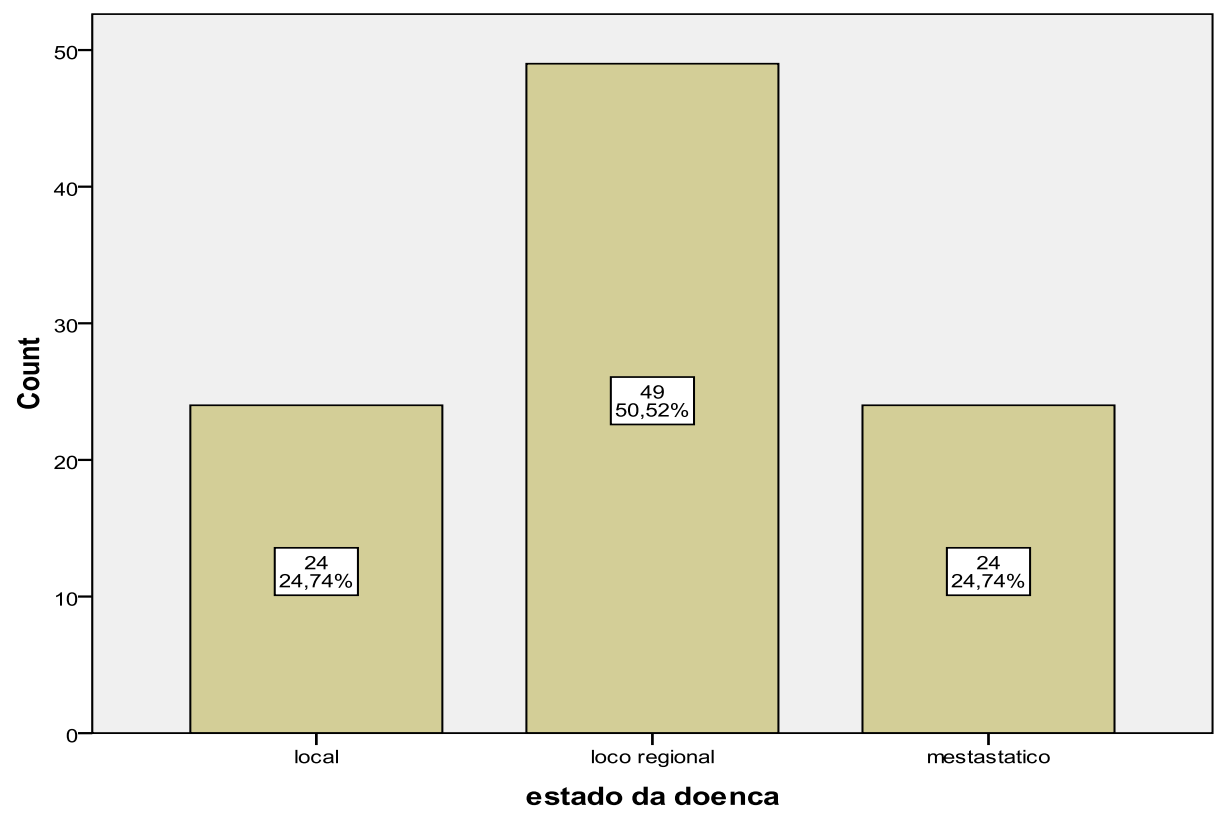

\section{II.2.2.3. Tratamento}

Aquando da participação no estudo, as doentes encontravam-se a realizar em maior número (48.04\%) outros tratamentos (a saber, hormonoterapia e imunoterapia) e quimioterapia (37.25\%). 


\section{Gráfico 9}

Frequências e Percentagens relativas ao Tratamento realizado

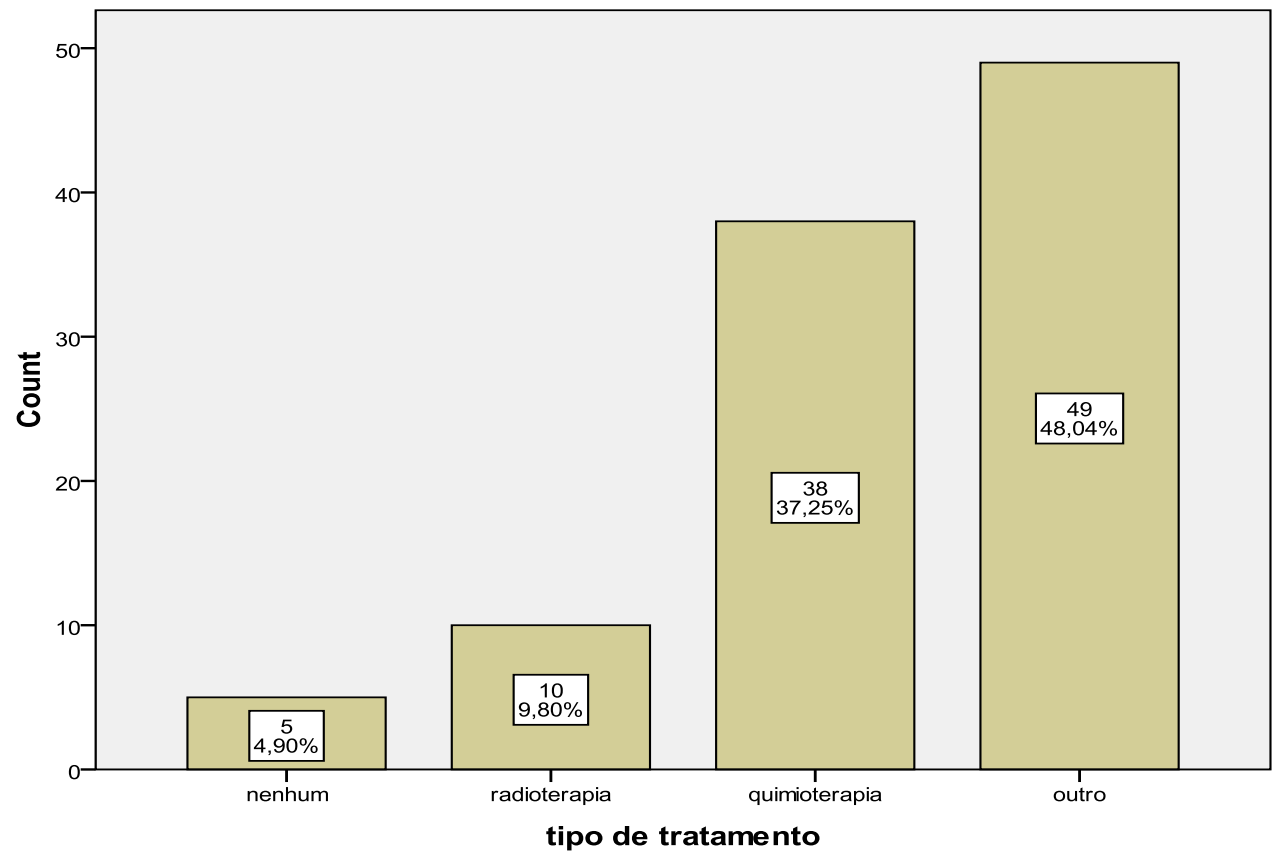

\section{II.2.2.4. Cirurgia}

A generalidade das doentes é mastectomizada, sendo que, $73.03 \%$ fez mastectomia radical e a $6.74 \%$ parcial. 


\section{Gráfico 10}

Frequências e Percentagens relativas ao tipo de Cirurgia realizada

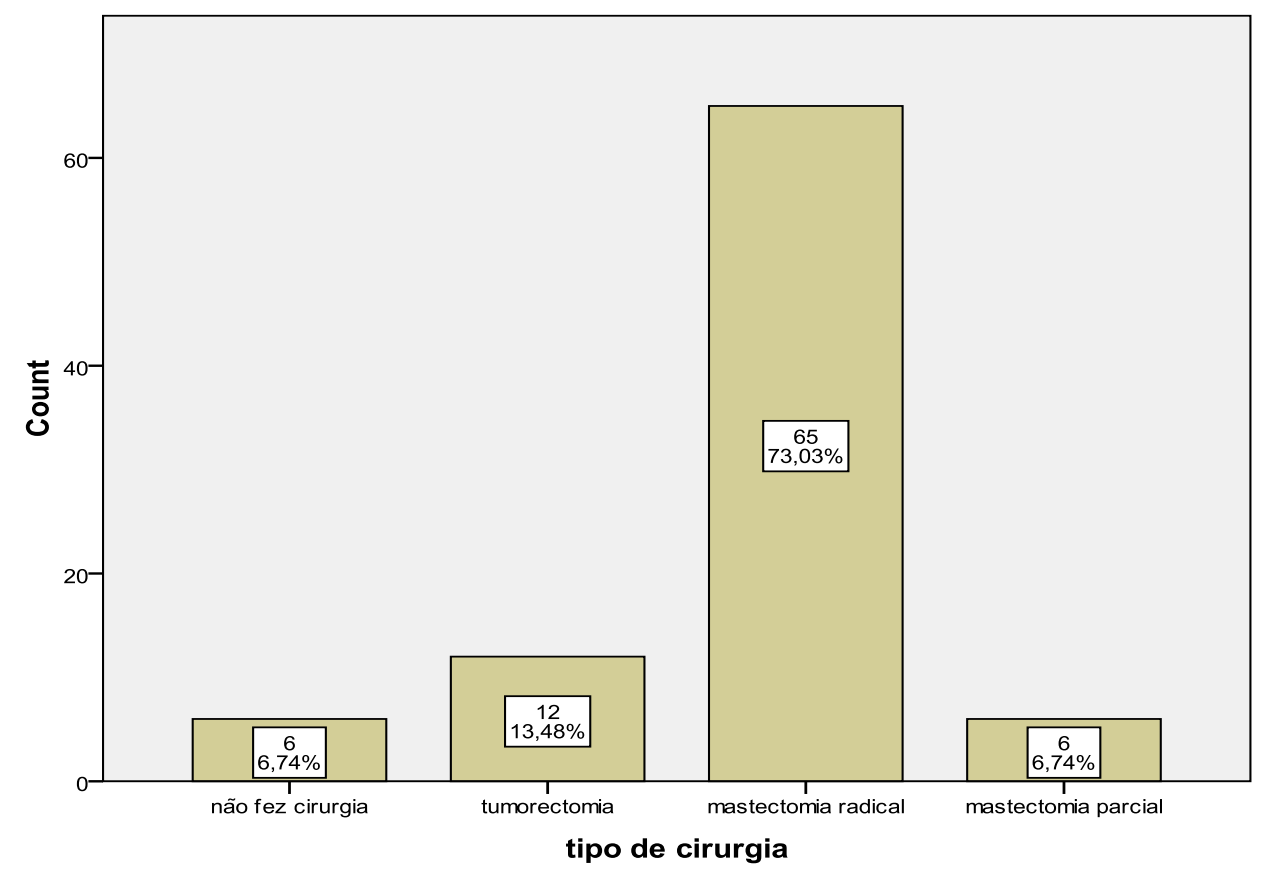

\section{II.2.2.5. Prognóstico}

A maioria das participantes tem prognóstico razoável (50\%), mas um número considerável tem mau prognóstico (30.39\%). Têm bom prognóstico apenas $18.6 \%$ das doentes. 


\section{Gráfico 11}

Frequências e Percentagens relativas ao Prognóstico

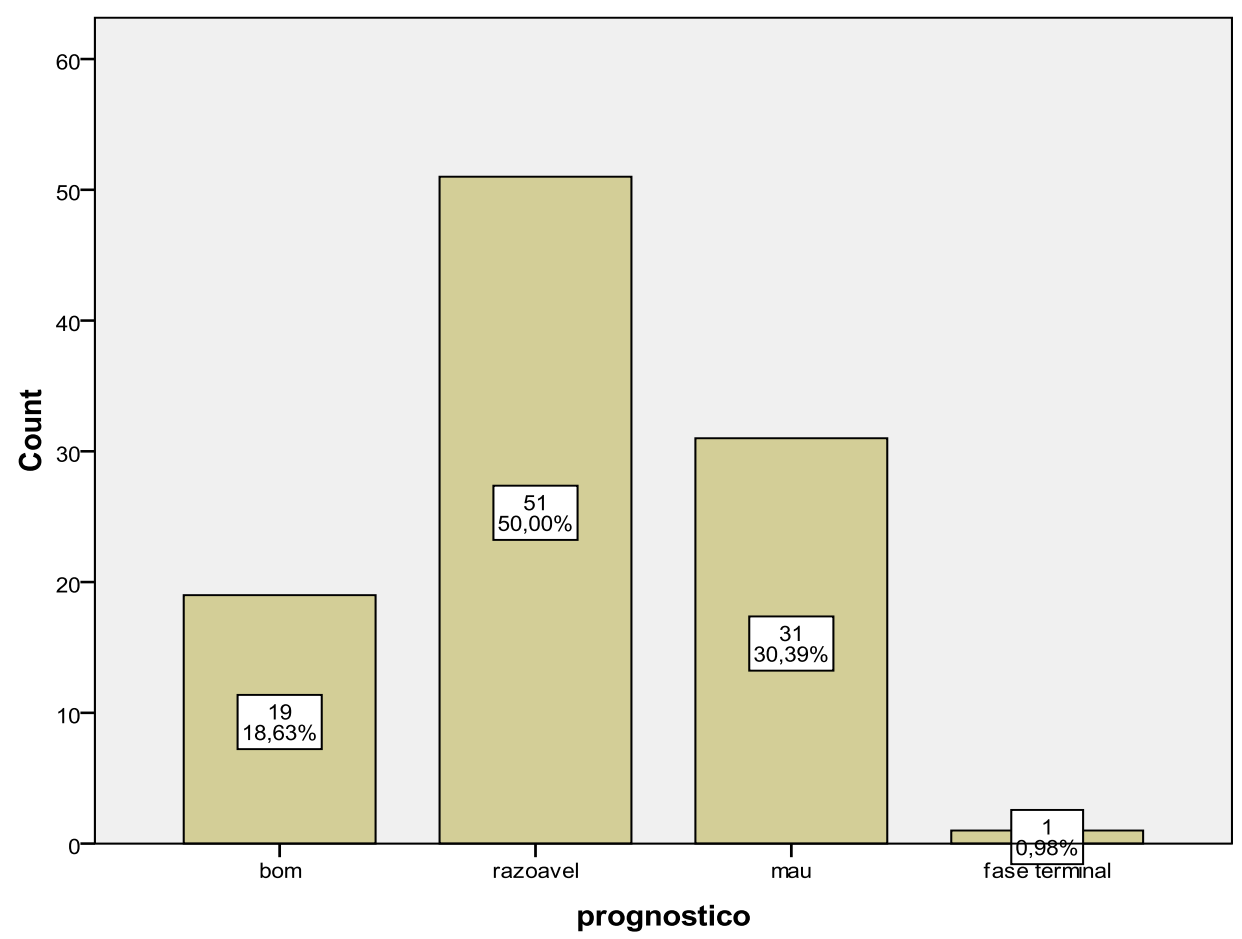

\section{II.2.2.6. Conhecimento da doença}

Como podemos constatar no gráfico 12, a doença é do conhecimento da generalidade das doentes (98\%). 


\section{Gráfico 12}

Frequências e Percentagens relativas ao Conhecimento da Doença

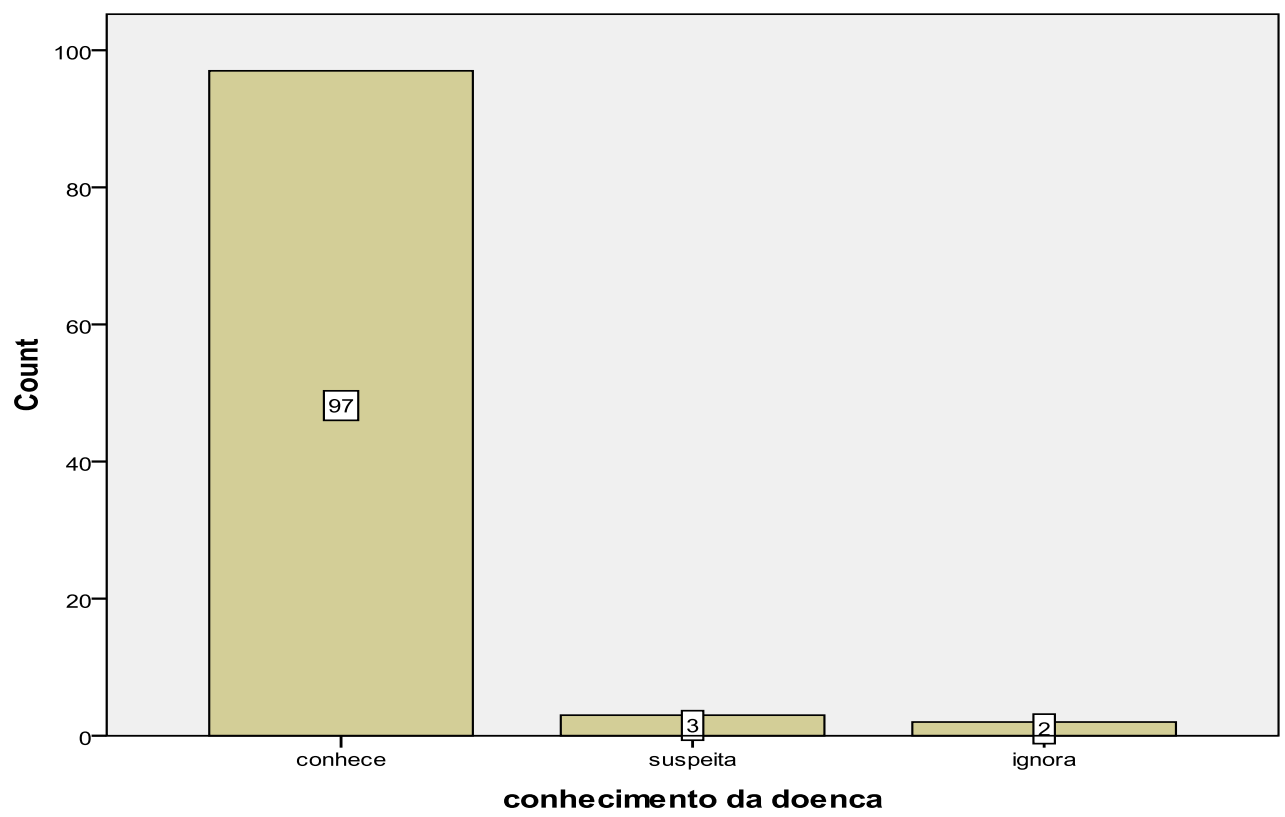

\section{II.2.2.7. Sintomas Físicos}

No que respeita às queixas sintomáticas relatadas aos clínicos, o sintoma mais referido pelas doentes foi a astenia (43\%), seguindo-se da incapacidade funcional (17\%) e da dor (14\%). Outros sintomas foram apontados por 5\% das doentes com cancro da mama estudadas. 


\section{II.2.3. Variáveis Empíricas}

\section{II.2.3.1. Sofrimento - Inventário de Experiência Subjetiva de Sofrimento na Doença (IESSD)}

\section{II.2.3.1.1. Caracterização da Experiência Subjetiva de Sofrimento na Doença das doentes com cancro da mama}

Com o objetivo de testarmos a $\mathrm{H} 1$ - prevê-se que as doentes com cancro da mama experimentam sofrimento psicológico durante a doença, foi efetuada análise de frequências e desvio padrão das dimensões do sofrimento do IESSD. Para tal, o somatório de cada dimensão do sofrimento foi dividido pelo número de itens, obtendose assim, a média e desvio padrão do nível de intensidade de cada uma.

Como podemos observar na tabela 7 , tendo em conta os resultados verificados, as doentes com cancro da mama estudadas experimentam sofrimento na doença, sendo o sofrimento socio-relacional $(M=2.85 ; D P=0.87)$, seguido de sofrimento psicológico $(M=2.58 ; D P=0.82)$, os que registam maiores índices, aceitando-se assim H1. É de sublinhar que o sofrimento das doentes regista-se num nível próximo da intensidade média. Sendo a variável medida por cinco níveis de intensidade, 1). ausência de sofrimento, 2). sofrimento ligeiro; 3). Sofrimento médio; 4). muito sofrimento; 5). sofrimento profundo, as médias do sofrimento das doentes da amostra situam-se próximas do nível 3. Sublinha-se ainda, não obstante, que as participantes do estudo mostram-se positivas face à experiência de doença $(M=2.84 ; D P=0.88)$, sendo esta dimensão do sofrimento a segunda que regista valores mais expressivos. Os resultados obtidos confirmam assim a hipótese formulada face à mostra estudada. 


\section{Tabela 7}

Estatística descritiva relativa à avaliação do sofrimento nas doentes com cancro da mama estudadas através do IESSD

\begin{tabular}{lcccc}
\hline & \multicolumn{4}{c}{$\boldsymbol{N = 1 0 4}$} \\
\cline { 2 - 5 } Dimensões IESSD & $\boldsymbol{M}$ & $\boldsymbol{D P}$ & Mínimo & Máximo \\
\hline Sofrimento Físico & 2.29 & .84 & 1.00 & 4.50 \\
Sofrimento Psicológico & 2.58 & .82 & 1,15 & 4.54 \\
Sofrimento Socio-relacional & 2.85 & .87 & 1,00 & 5.00 \\
Sofrimento Existencial & 2.34 & .73 & 1,19 & 4.38 \\
Experiências Positivas & 2.84 & .88 & 1,20 & 5.00 \\
\hline
\end{tabular}

Em ordem a observar se as mulheres da amostra deste estudo evidenciavam diferenças significativas ao nível das cinco dimensões do sofrimento - espera-se que a experiência de sofrimento na doença em doentes com cancro da mama difira, foram efetuados testes- $t$ para amostras emparelhadas, de modo similar às medidas repetidas. Dito de outro modo, cada uma das dimensões foi comparada às restantes, resultando num total de nove comparações de pares de resultados dimensionais.

Os resultados indicaram a existência de diferenças significativas nas médias entre todos os pares avaliados, à exceção dos pares sofrimento físico vs. existencial $t(103)=-.85, p=.40, \eta^{2}=.01,95 \%$ I.C. $[-.18,-.07]$, e sofrimento socio-relacional vs. experiências positivas $t(103)=.13, p=.90, \eta^{2}=.00,95 \%$ I.C. [-.22, .25]. Quanto aos resultados significativos, estes encontram-se nos seguintes pares: sofrimento físico vs. socio-relacional $t(103)=-6.02 . p=.00, \eta^{2}=.26,95 \%$ I.C. $[-.75,-.38]$, sofrimento físico vs. psicológico $t(103)=4.60, p=.00, \eta^{2}=.17,95 \%$ I.C. [-.42, -.17], sofrimento físico vs. experiências positivas do sofrimento $t(103)=-.4 .10, p=.00, \eta^{2}=.14,95 \%$ I.C. $[-.81,-.28]$, sofrimento socio-relacional vs. psicológico $t(103)=3.83, p=.00, \eta^{2}=.12,95 \%$ I.C. [.13, .41], sofrimento socio-relacional vs. existencial $t(103)=8.05, p=.00, \eta^{2}=.38,95 \%$ I.C. $[.38, .63]$, sofrimento psicológico vs. existencial $t(103)=5.29, p=.00, \eta^{2}=.21,95 \%$ I.C. $[.15, .33]$, e por último, sofrimento existencial vs. experiências positivas de sofrimento 
na doença $t(103)=-4.28, p=.00, \eta^{2}=.15,95 \%$ I.C. $[-.72,-.26]$. Sublinhamos que o poder das diferenças encontradas encontra expressão na robustez dos valores de eta obtidos.

Como podemos constatar na tabela 8 o sofrimento físico nas doentes com cancro da mama estudas é significativamente menor comparativamente com o sofrimento socio-relacional, psicológico, e com as experiências positivas de sofrimento na doença. O sofrimento físico é igualmente menor ao sofrimento existencial no grupo estudado, todavia, esta diferença não é estatisticamente significativa. O sofrimento sociorelacional é nestas doentes significativamente superior ao sofrimento psicológico e existencial. Apesar das doentes também apresentarem maior sofrimento sociorelacional que experiências positivas do sofrimento, esta diferença não se revelou significativa. Por último, o sofrimento psicológico e as experiências positivas no sofrimento são significativamente superiores ao sofrimento existencial.

Tabela 8

Diferenças de médias e desvio padrão na comparação entre pares das dimensões do sofrimento

\begin{tabular}{|c|c|c|c|}
\hline \multirow[b]{2}{*}{ Dimensões } & \multicolumn{3}{|c|}{$N=104$} \\
\hline & $M$ & $D P$ & IC $95 \%$ \\
\hline \multicolumn{4}{|l|}{ Par 1} \\
\hline Sofrimento físico & $2.29 *$ & .85 & \multirow[t]{2}{*}[-.75,-.38]{} \\
\hline Sofrimento socio-relacional & $2.86^{*}$ & .87 & \\
\hline \multicolumn{4}{|l|}{ Par 2} \\
\hline Sofrimento físico & $2.29 *$ & .85 & \multirow[t]{2}{*}[-.42,-.17]{} \\
\hline Sofrimento psicológico & $2.58^{*}$ & .83 & \\
\hline \multicolumn{4}{|l|}{ Par 3} \\
\hline Sofrimento físico & 2.29 & .85 & \multirow[t]{2}{*}[-.18,.07]{} \\
\hline Sofrimento existencial & 2.35 & .73 & \\
\hline \multicolumn{4}{|l|}{ Par 4} \\
\hline Sofrimento físico & $2.29 *$ & .85 & \multirow[t]{2}{*}[-.81,-.28]{} \\
\hline Experiências positivas & $2.84 *$ & .88 & \\
\hline \multicolumn{4}{|l|}{ Par 5} \\
\hline Sofrimento sócio-relacional & $2.86^{*}$ & .87 & \multirow[t]{2}{*}[.13,.41]{} \\
\hline Sofrimento psicológico & $2.58^{*}$ & .83 & \\
\hline \multicolumn{4}{|l|}{ Par 6} \\
\hline Sofrimento sócio-relacional & $2.86^{*}$ & .87 & \multirow[t]{2}{*}[.38,.63]{} \\
\hline Sofrimento existencial & $2.35^{*}$ & .73 & \\
\hline \multicolumn{4}{|l|}{$\begin{array}{l}\text { Par } 7 \\
\text { Pallo }\end{array}$} \\
\hline Sofrimento sócio-relacional & 2.86 & .87 & \multirow[t]{2}{*}[-.22,.25]{} \\
\hline Experiências positivas & 2.84 & .88 & \\
\hline \multicolumn{4}{|l|}{ Par 8} \\
\hline Sofrimento psicológico & $2.58^{*}$ & .83 & \multirow[t]{2}{*}[.15,.33]{} \\
\hline Sofrimento existencial & $2.35^{*}$ & .73 & \\
\hline \multicolumn{4}{|l|}{ Par 9} \\
\hline Sofrimento existencial & $2.35^{*}$ & .73 & \multirow[b]{2}{*}[-.72,-.26]{} \\
\hline Expetativas positivas do sofrimento & $2.84^{*}$ & .88 & \\
\hline
\end{tabular}




\section{II.2.3.1.2. Diferenças na Experiência de Sofrimento na Doença em função das variáveis sociodemográficas: idade, estado civil e escolaridade}

Quisemos avaliar se a experiência de sofrimento na doença das doentes com cancro da mama estudadas difere em função das variáveis sociodemográficas, com o intuito de testar $\mathrm{H} 2$ - espera-se que a experiência de sofrimento na doença difira significativamente em função das variáveis sociodemográficas: idade, estado civil e escolaridade. Para o efeito foi realizada uma análise de variância multivariada (MANOVA), tendo como variáveis dependentes as cinco dimensões do sofrimento, avaliadas através do IESSD e como variável independente, em primeiro lugar, o fator idade das doentes com cancro da mama em estudo. Nos testes post hoc optou-se pelo critério de Scheffé (Scheffé, 1953), por ser considerado um teste conservador (Tabachnick \& Fidell, 1996), por forma a compensar eventuais resultados espúrios. Foram ainda equacionados valores do Eta-quadrado, com o intuito de avaliar o poder das associações entre as variáveis. Como critério de significância recorreu-se ao Quiquadrado $\left(x^{2}\right)$ a $5 \%(\mathrm{p} \leq .05)$.

Ao nível dos testes multivariados foram reportados efeitos significativas $[\mathrm{F}(15$, $294)=1.88, p=.03, \eta^{2}=.09$ ] entre a variável idade e as dimensões do sofrimento. Não obstante, em análise posteriores, recorrendo ao teste de Pillai's, o poder da interação da idade revelou-se espúria com as variáveis sofrimento físico $[F(3,100)=1.97, p=.12$, $\left.\eta^{2}=.06\right]$, sofrimento socio-relacional $\left[F(3,100)=2.58, p=.06, \eta^{2}=.07\right]$, sofrimento psicológico $\left[F(3,100)=1.45, p=.23, \eta^{2}=.04\right]$, sofrimento existencial $[F(3,100)=.91$, $\left.p=.44, \eta^{2}=.03\right]$, e experiências positivas de sofrimento $\left[F(3,100)=2.64, p=.05, \eta^{2}=.03\right]$. O mesmo processo foi repetido, tendo como variável independente o fator estado civil. Os testes multivariados mostraram interação significativa entre as variáveis em 
estudo $\left[F(15,294)=1.85, p=.03, \eta^{2}=.09\right]$. Todavia, as analises posteriores efetuadas evidenciam resultados espúrios na associação entre o estado civil e o sofrimento físico $\left[F(3,100)=1.71, p=.17, \eta^{2}=.05\right]$, sofrimento socio-relacional $[F(3,100)=1.10, p=.12$, $\left.\eta^{2}=.06\right]$, sofrimento psicológico $\left[F(3,100)=1.22, p=.31, \eta^{2}=.04\right]$, sofrimento existencial $\left[F(3,100)=.82, p=.49, \eta^{2}=.02\right]$ e experiências positivas do sofrimento $[F(3,100)=2.40$, $\left.p=.07, \eta^{2}=.07\right]$.

Por último, foi realizada análise de variância multivariada tendo com variável independente a escolaridade. Os resultados obtidos através dos testes multivariados indicaram um efeito significativo da escolaridade nas dimensões do sofrimento $[F(15$, 294) $=2.85, p=.00, \eta^{2}=.13$ ]. Os testes de efeitos entre sujeitos indicaram diferenças significativas ao nível do sofrimento físico $\left[F(3,100)=7.61, p=.00, \eta^{2}=.19\right.$, do sofrimento psicológico $\left[F(3,100)=2.34, p=.01, \eta^{2}=.11\right]$, do sofrimento existencial $[F(3$, $\left.100)=3.53, p=.02, \eta^{2}=.10\right]$, e finalmente das experiências positivas do sofrimento $[F(3$, $\left.100)=5.98, p=.00, \eta^{2}=.15\right]$. Os resultados indicaram ainda, que o fator escolaridade não tem nesta amostra um efeito significativo relativamente ao sofrimento socio-relacional $\left[F(3,100)=2.34, p=.08, \eta^{2}=.07\right]$.

Como podemos comprovar pelos valores descriminados na tabela 9, os testes post hoc revelaram que as mulheres com frequência do ensino superior apresentavam valores de sofrimento físico significativamente inferiores $(\mathrm{M}=1.42, \mathrm{DP}=.28), \mathrm{IC} 95 \%$ $[1.01,1.83]$ às que não frequentaram a escola $(\mathrm{M}=2,56, \mathrm{DP}=1.01), p=.01, \mathrm{IC} 95 \%$ $[2.02,3.11]$ ou que detêm o ensino básico $(\mathrm{M}=2.47, \mathrm{DP}=.84), p=.00$, IC 95\% [2.51, 2.89]. Também são as mulheres com as qualificações mais elevadas que detêm valores de sofrimento psicológico significativamente inferior ( $\mathrm{M}=1.91, \mathrm{DP}=.57)$, IC 95\% [1.49, 2.33] daquelas que têm frequência do ensino básico $(\mathrm{M}=2.70, \mathrm{DP}=.81), p=.01$, I.C $95 \%$ $[2.51,2.89]$. O mesmo padrão acontece relativamente ao sofrimento existencial, sendo 
as mulheres com frequência do ensino superior a deterem médias significativamente inferiores $(\mathrm{M}=1.81, \mathrm{DP}=.31)$, IC 95\% [1.44, 219] às mulheres cujas habilitações correspondem ao ensino básico ( $\mathrm{M}=2.48, \mathrm{DP}=.75), p=.02,95 \%$ [2.31, 2.60]. Finalmente, as mulheres com frequência universitária apresentam valores significativamente superiores $(\mathrm{M}=3.60, \mathrm{DP}=.60)$, IC 95\% [ 3.16, 4.04] em termos de experiências positivas de sofrimento quando comparadas às que não frequentaram qualquer grau de ensino $(\mathrm{M}=2.15, \mathrm{DP}=.70), p=.00, \mathrm{IC} 95 \%[1.57,2.73]$ e ainda àquelas que detêm o ensino básico ( $\mathrm{M}=2.77, \mathrm{DP}=.85), p=.01$, IC 95\% [ 2.57, 2.97].No caso, H2 confirma-se em parte, comprovou-se que apenas a variável escolaridade, do grupo das sociodemográficas, tem efeitos significativos na experiência de sofrimento na doença.

\section{Tabela 9}

Diferenças de Médias e Desvio Padrão das dimensões do sofrimento em função da escolaridade

\begin{tabular}{|c|c|c|c|c|c|c|c|c|c|c|c|c|c|}
\hline \multicolumn{14}{|c|}{ Grupos de escolaridade } \\
\hline \multirow{2}{*}{$\mathscr{\Omega}$} & \multicolumn{2}{|c|}{1} & \multicolumn{4}{|c|}{2} & \multicolumn{2}{|c|}{3} & \multicolumn{4}{|c|}{4} & \multirow[b]{2}{*}{ Dif. } \\
\hline & $M$ & $D P$ & IC $a 95 \%$ & $M$ & $D P$ & IC a $95 \%$ & $M$ & $D P$ & IC a $95 \%$ & $M$ & $D P$ & IC a $95 \%$ & \\
\hline $\mathrm{F}$ & 2.56 & 1.01 & {$[2.02,3.11]$} & 2.47 & .84 & {$[2.29,2.66]$} & 2.17 & .64 & {$[1.77,2.56]$} & 1.42 & .28 & {$[1.01,1.83]$} & $4<1,2$ \\
\hline $\mathrm{P}$ & 2.56 & .84 & {$[2.00,3.11]$} & 2.70 & .81 & {$[2.51,2.89]$} & 2.71 & .86 & {$[2.31,3.12]$} & 1.91 & .57 & {$[1.49,2.33]$} & $4<2$ \\
\hline SR & 2.23 & .63 & {$[1.63,2.83]$} & 2.97 & .84 & {$[2.76,3.18]$} & 2.93 & 1.05 & {$[2.50,3.37]$} & 2.58 & .79 & {$[2.13,3.04]$} & n.s. \\
\hline $\mathrm{E}$ & 2.26 & .75 & {$[1.76,2.75]$} & 2.48 & .75 & {$[2.31,2.60]$} & 2.30 & .71 & {$[1.95,2.67]$} & 1.81 & .31 & {$[1.44,2.19]$} & $4<2$ \\
\hline EP & 2.15 & .70 & {$[1.57,2.73]$} & 2.77 & .85 & {$[2.57,2.97]$} & 2.83 & .93 & {$[2.40,3.25]$} & 3.60 & .60 & {$[3.16,4.04]$} & $4>1,2$ \\
\hline
\end{tabular}

Nota. DS=Dimensões do sofrimento, F=Sofrimento Físico; P=Sofrimento Psicológico; SR=Sofrimento sócio-relacional; E=Sofrimento Existencial; EP=Experiências Positivas.

Grupos de escolaridade: 1 = Não frequentou a escola; $2=$ =nsino básico, $3=$ =nsino secundário; $4=$ =nsino superior

As diferenças reportadas apresentam significância estatística de $p \leq .05$; n.s. não significativo 


\section{II.2.3.1.3. Diferenças na Experiência Subjetiva de Sofrimento na Doença em}

função das variáveis clínicas: estadio, sintomas, tratamento, cirurgia e prognóstico

Com o objetivo de determinar se a experiência subjetiva de sofrimento na doença difere nas doentes com cancro da mama em função das variáveis clínicas do curso da doença, quisemos testar $\mathrm{H} 3$ - postula-se que a experiência de sofrimento na doença difira significativamente em função das variáveis clínicas: estadio, sintomas, tratamento, cirurgia e prognóstico. Para o efeito, à semelhança dos procedimentos estatísticos realizados na testagem da hipótese anterior, foi efetuada análise de variância multivariada (MANOVA), tendo como variáveis dependentes as cinco dimensões do sofrimento do IESSD e como variável independente cada uma das variáveis clínicas. Como critério de significância recorreu-se ao Qui-quadrado $\left(x^{2}\right)$ a $10 \%(\mathrm{p} \leq .01)$.

Não foram encontrados efeitos estatisticamente significativos do estadio da doença $\left[F(10,18)=.76, p=.67, \eta^{2}=.04\right]$, sintoma físico dor $\left[F(5,96)=1.18, p=.32, \eta^{2}=\right.$ .06], sintoma físico astenia $\left[F(5,96)=1.35, \quad p=.25, \quad \eta^{2}=.07\right], \quad$ outros sintomas $\left[F(5,96)=1.02, p=.41, \eta^{2}=.05\right]$, tipo de tratamento $\left[F(15,29)=.82, p=.65, \eta^{2}=.04\right]$, prognóstico $\left[F(10,19)=1.40, p=.18, \eta^{2}=.07\right]$ nas dimensões do sofrimento. Porém, os testes multivariados demonstraram que o sintoma físico diminuição da funcionalidade exerce um efeito estatisticamente significativo $\left[F(5,96)=4.09, p=.00, \eta^{2}=.18\right]$ no sofrimento, nomeadamente nas dimensões física $\left[F(1,100)=9.10, p=.00, \eta^{2}=.08\right] \mathrm{e}$ experiências positivas $\left[F(1,100)=6.48, p=.01, \eta^{2}=.06\right]$. O mesmo não se verifica nas restantes dimensões do sofrimento: socio-relacional $\left[F(1,100)=1.19, p=.28, \eta^{2}=.01\right]$, 
psicológico $\left[F(1,100)=2.95, p=.09, \eta^{2}=.03\right]$, e existencial $\left[F(1,100)=.37, p=.55, \eta^{2}=.00\right]$, os efeitos não se revelam significativos. Foi também encontrado efeito significativo do tipo de cirurgia $\left[F(15,25)=2.13, p=.01, \eta^{2}=.11\right]$ na variável sofrimento. Sendo o mesmo apenas significativo na dimensão experiências positivas do sofrimento $[F(3,85)=6.38$,

$\left.p=.00, \eta^{2}=.18\right]$. Nas restantes dimensões: sofrimento físico $\left[F(3,89)=.68, p=.57, \eta^{2}=.02\right]$, socio-relacional $\left[F(3,89)=1.06, p=.37, \eta^{2}=.04\right]$, psicológico $[F(3,89)=1.42, p=.24$, $\left.\eta^{2}=.05\right]$ e existencial $\left[F(3,89)=.38, p=.77, \eta^{2}=.01\right]$ os efeitos não se revelaram significativos.

Os testes post hoc reportam que as doentes com cancro da mama diferem em termos de experiências positivas de sofrimento na doença quanto ao tipo de cirurgia $\left[F(3,85)=6.38, p=.00, \eta^{2}=.18\right]$, verificando-se valores mais elevados nas experiências positivas de sofrimento na doença nas doentes que não fizeram cirurgia $(\mathrm{M}=4.00$, $\mathrm{DP}=.74)$ I.C. a $99 \%[3.16,4.84]$ comparativamente com as que realizaram mastectomia radical $(\mathrm{M}=2.59, \mathrm{DP}=.80), p=.00, \mathrm{IC} 99 \%$ [2.33, 2.85]. Relativamente à variável sintoma físico não foram realizados teste post hoc, em virtude da variável ser dicotómica.

\section{II.2.3.2. Sintomatologia Psicopatológica - Brief Symptoms Inventory (BSI)}

\section{II.2.3.2.1. Avaliação da Sintomatologia Psicopatológica das doentes com cancro da mama em estudo}

Com o intuito de testarmos $\mathrm{H} 4$ - prevê-se que as doentes com cancro da mama apresentam diferente sintomatologia psicopatológica, foi efetuada análise de frequências e de desvio padrão de cada uma das dimensões de sintomas 
psicopatológicos do BSI. Como podemos observar na tabela 10, os quadros sintomatológicos que revelam maiores índices na população estudada são: a ansiedade, sendo o que regista um valor mais elevado $(M=2.46, D P=.83)$, seguido da obsessãocompulsão $(M=2.27, D P=.78)$, somatização $(M=2.22, D P=.72)$ e depressão $(M=2.05$, $D P=.84)$. Atendendo à intensidade dos sintomas psicopatológicos avaliados pelo BSI, de 0 a 4, sendo que 0 - revela a ausência de sintoma, 1- poucas vezes, 2- algumas vezes, 3- muitas vezes, 4- presença recorrente do sintoma, podemos concluir que os sintomas mais frequentes são de severidade ligeira com tendência a moderada. Ficando assim comprovada a hipótese formulada.

Tabela 10

Média e Desvio Padrão dos Sintomas Psicopatológicos das doentes com cancro da mama avaliadas

\begin{tabular}{lcccc}
\hline & \multicolumn{4}{c}{$\boldsymbol{N = 1 0 4}$} \\
\cline { 2 - 5 } Sintomas Psicológicos & Mínimo & Máximo & $\boldsymbol{M}$ & $\boldsymbol{D P}$ \\
\hline Somatização & 1.00 & 3.71 & 2.22 & .72 \\
Depressão & 1.00 & 4.00 & 2.05 & .84 \\
Hostilidade & 1.00 & 3.20 & 1.80 & .55 \\
Ansiedade Fóbica & 1.00 & 3.20 & 1.60 & .61 \\
Psicoticismo & 1.00 & 4.00 & 1.63 & .64 \\
Paranóide & 1.00 & 3.80 & 1.86 & .68 \\
Obsessão-Compulsão & 1.00 & 4.50 & 2.27 & .78 \\
Sensibilidade Interpessoal & 1.00 & 4.00 & 1.89 & .76 \\
Ansiedade & 1.00 & 5.40 & 2.46 & .83 \\
IGS & .96 & 4.49 & 1.87 & .54 \\
TSP & 1.19 & 27.50 & 4.51 & 4.30 \\
ISP & 2.00 & 146.00 & 34.31 & 24.56 \\
\hline
\end{tabular}

Procuramos ainda estudar se existiam diferenças estatisticamente significativas entre as doentes com cancro da mama observadas ao nível das dimensões dos sintomas psicopatológicos. Para tal, foram efetuados testes- $t$ para amostras emparelhadas, comparando cada uma das dimensões com as restantes, resultando num total de 36 comparações de pares de resultados dimensionais. 
Como podemos comprovar na tabela 11 a análise estatística demonstrou que existem diferenças entre as dimensões dos sintomas psicopatológicos na amostra estuda, tendo-se verificado que estas diferenças são estatisticamente significativas entre a maioria das dimensões analisadas. As diferenças não se revelaram significativas nas dimensões somatização vs. obsessão-compulsão $t(103)=.73, p=.47, \eta^{2}=.01,99 \%$ IC [23, .13]; hostilidade vs. ideação paranoide $t(103)=-.92, p=.36, \eta^{2}=.01,99 \%$ IC [-.22, .11]; hostilidade vs. sensibilidade interpessoal $t(103)=-1.31, p=.19, \eta^{2}=.12,99 \%$ IC [$.25, .08]$; ansiedade fóbica vs. psicoticismo $t(103)=-.31, p=.76, \eta^{2}=9.08,99 \%$ IC $[-.17$, .13]; e por último, ideação paranoide vs. sensibilidade interpessoal t(103)=-.47, $p=.64$, $\eta^{2}=.00,99 \%$ IC $[-.17, .12]$.

Tendo em conta os resultados documentados, podemos dizer que nas doentes com cancro da mama da amostra apresentam significativamente mais ansiedade que os restantes sintomas avaliados pelo BSI, a saber: somatização, depressão, obsessãocompulsão, hostilidade, ansiedade fóbica, paranoide, psicoticismo e sensibilidade interpessoal. O mesmo padrão se repete relativamente ao sintoma obsessão-compulsão, encontrando-se significativamente de forma superior nas doentes observadas comparativamente às outras sete dimensões de sintomas psicopatológicos (exceto a ansiedade). O sintoma somatização tem uma prevalência significativamente superior neste grupo de doentes à depressão, hostilidade, ansiedade fóbica, psicoticismo, ideação paranoide e sensibilidade interpessoal. Por fim, a depressão encontra-se em níveis significativamente superiores nas doentes com cancro da mama estudadas que a hostilidade, ansiedade fóbica, psicoticismo, paranoide e sensibilidade interpessoal. 
Tabela 11

Diferenças de médias e desvio padrão dos pares constituídos paras as dimensões dos sintomas psicopatológicos

\begin{tabular}{|c|c|c|c|c|c|c|}
\hline \multirow[b]{3}{*}{ Pares Dimensões } & \multicolumn{6}{|c|}{$N=104$} \\
\hline & \multirow[b]{2}{*}{$M$} & \multirow[b]{2}{*}{$D P$} & \multirow[b]{2}{*}{$t$} & \multicolumn{3}{|c|}{$95 \%$} \\
\hline & & & & $p$ & $I C$ & $\eta^{2}$ \\
\hline \multicolumn{7}{|l|}{ Par 1} \\
\hline Somatização & 2.22 & .72 & 2.12 & $.04 *$ & {$[-.04, .38]$} & .04 \\
\hline Depressão & 2.05 & .84 & & & & \\
\hline \multicolumn{7}{|l|}{ Par 2} \\
\hline Somatização & 2.22 & .72 & 5.66 & $.00 *$ & {$[.22, .61]$} & .23 \\
\hline Hostilidade & 1.80 & .55 & & & & \\
\hline \multicolumn{7}{|l|}{ Par 3} \\
\hline Somatização & 2.22 & .72 & 9.92 & $.00 *$ & {$[.43, .80]$} & .44 \\
\hline \multirow{2}{*}{\multicolumn{7}{|c|}{ Par 4}} \\
\hline & & & & & & \\
\hline Somatização & 2.22 & .72 & 7.74 & $.00 *$ & {$[.39, .80]$} & .37 \\
\hline Psicoticismo & 1.63 & .64 & & & & \\
\hline \multicolumn{7}{|l|}{ Par 5} \\
\hline Somatização & 2.22 & .72 & 4.60 & $.00 *$ & {$[.16, .57]$} & .17 \\
\hline Paranoide & 1.86 & .68 & & & & \\
\hline \multicolumn{7}{|l|}{ Par 6} \\
\hline Somatização & 2.22 & .72 & -.73 & .47 & {$[-.23, .13]$} & .01 \\
\hline Obsessã̃o-compulsão & 2.27 & .78 & & & & \\
\hline \multicolumn{7}{|l|}{ Par 7} \\
\hline Somatização & 2.22 & .72 & 4.11 & $.00 *$ & {$[.12, .55]$} & .14 \\
\hline Sensibilidade Interpessoal & 1.89 & .76 & & & & \\
\hline Par 8 & & & & & & \\
\hline Somatização & 2.22 & .72 & -3.37 & $.00 *$ & {$[-.42,-.05]$} & .10 \\
\hline Ansiedade & 2.46 & .83 & & & & \\
\hline Par 9 & & & & & & \\
\hline Depressão & 2.05 & .84 & 3.34 & $.00 *$ & {$[.05, .44]$} & .10 \\
\hline Hostilidade & 1.80 & .55 & & & & \\
\hline Par 10 & & & & & & \\
\hline Depressão & 2.05 & .84 & 5.98 & $.00 *$ & {$[.25, .64]$} & .37 \\
\hline Ansiedade Fóbica & 1.61 & .61 & & & & \\
\hline Par 11 & & & & & & \\
\hline Depressão & 2.05 & .84 & 6.90 & $.00 *$ & {$[.26, .59]$} & .32 \\
\hline Psicoticismo & 1.63 & .64 & & & & \\
\hline Par 12 & & & & & & \\
\hline Depressão & 2.05 & .84 & 2.65 & $.01 *$ & {$[.00, .38]$} & .06 \\
\hline Paranoide & 1.86 & .68 & & & & \\
\hline Par 13 & & & & & & \\
\hline Depressão & 2.05 & .84 & -3.34 & $.00 *$ & {$[-.39,-.05]$} & .10 \\
\hline Obsessão-Compulsão & 2.27 & .78 & & & & \\
\hline Par 14 & & & & & & \\
\hline Depressão & 2.05 & .84 & 2.43 & $.02 *$ & {$[-.01, .34]$} & .05 \\
\hline sensibilidade-Interpessoal & 1.89 & .76 & & & & \\
\hline Par 15 & & & & & & \\
\hline Depressão & 2.05 & .84 & -5.98 & $.00 *$ & {$[-.58,-.23]$} & .26 \\
\hline Ansiedade & 2.46 & .83 & & & & \\
\hline Par 16 & & & & & & \\
\hline Hostilidade & 1.80 & .55 & 3.11 & .00 & {$[.03, .36]$} & .09 \\
\hline Ansiedade Fóbica & 1.61 & .61 & & & & \\
\hline Par 17 & & & & & & \\
\hline Hostilidade & 1.80 & .55 & 3.24 & $.00 *$ & {$[.03, .32]$} & .09 \\
\hline Psicoticismo & 1.63 & .64 & & & & \\
\hline Par 18 & & & & & & \\
\hline Hostilidade & 1.80 & .55 & .92 & .36 & {$[-.22, .11]$} & .01 \\
\hline Paranoide & 1.86 & .68 & & & & \\
\hline Par 19 & & & & & & \\
\hline Hostilidade & 1.80 & .55 & -6.74 & $.00 *$ & {$[-.65,-.29]$} & .31 \\
\hline Obsessão-Compulsão & 2.27 & .78 & & & & \\
\hline Par 20 & & & & & & \\
\hline Hostilidade & 1.80 & .55 & -1.31 & .19 & {$[-.25, .08]$} & .12 \\
\hline Sensibilidade Interpessoal & 1.89 & .76 & & & & \\
\hline Par 21 & & & & & & \\
\hline Hostilidade & 1.80 & .55 & -8.68 & $.00 *$ & {$[-.85,-.45]$} & .42 \\
\hline Ansiedade & 2.46 & .83 & & & & \\
\hline
\end{tabular}




\begin{tabular}{|c|c|c|c|c|c|c|}
\hline \multicolumn{7}{|l|}{ Par 22} \\
\hline $\begin{array}{l}\text { Ansiedade Fóbica } \\
\text { Psicotiscismo }\end{array}$ & 1.61 & .61 & -.31 & .76 & {$[-.17, .13]$} & 9.08 \\
\hline Psicotiscismo & 1.63 & .64 & & & & \\
\hline \multicolumn{7}{|l|}{ Par 23} \\
\hline Ansiedade Fóbica & 1.61 & .61 & -3.87 & $.00 *$ & {$[-.43,-.08]$} & .13 \\
\hline Paranoide & 1.86 & .68 & & & & \\
\hline \multicolumn{7}{|l|}{ Par 24} \\
\hline Ansiedade Fóbica & 1.61 & .61 & -9.64 & $.00 *$ & {$[-.85,-.48]$} & .47 \\
\hline Obsessão-Compulsão & 2.27 & .78 & & & & \\
\hline \multicolumn{7}{|l|}{ Par 25} \\
\hline Ansiedade Fóbica & 1.61 & .61 & -4.26 & $.00 *$ & {$[-.45,-.11]$} & .15 \\
\hline Sensibilidade Interpessoal & 1.89 & .76 & & & & \\
\hline \multicolumn{7}{|l|}{ Par 26} \\
\hline Ansiedade Fóbica & 1.61 & .61 & $-12,52$ & $.00 *$ & {$[-1.03,-.67]$} & .60 \\
\hline Ansiedade & 2.46 & .83 & & & & \\
\hline \multicolumn{7}{|l|}{ Par 27} \\
\hline Psicoticismo & 1.63 & .64 & -3.72 & $.00 *$ & {$[-.40,-.07]$} & .12 \\
\hline Paranoide & 1.86 & .68 & & & & \\
\hline \multicolumn{7}{|l|}{ Par 28} \\
\hline Psicoticismo & 1.63 & .64 & -9.12 & $.00 *$ & {$[-.83,-.46]$} & .45 \\
\hline Obsessão-Compulsão & 2.27 & .78 & & & & \\
\hline \multicolumn{7}{|l|}{ Par 29} \\
\hline Psicoticismo & 1.63 & .64 & -4.31 & $.00 *$ & {$[-.42,-.10]$} & .15 \\
\hline SensibilidadeInterpessoal & 1.89 & .76 & & & & \\
\hline \multicolumn{7}{|l|}{ Par 30} \\
\hline Psicotiscimo & 1.63 & .64 & -13.36 & $.00 *$ & {$[-.99,-.67]$} & .63 \\
\hline Ansiedade & 2.46 & .83 & & & & \\
\hline \multicolumn{7}{|l|}{ Par 31} \\
\hline Paranoide & 1.86 & .68 & -5.67 & $.00 *$ & {$[-.60,-.22]$} & .24 \\
\hline \multirow{2}{*}{\multicolumn{7}{|c|}{$\begin{array}{l}\text { Par } 32 \\
\text { Paste }\end{array}$}} \\
\hline & & & & & & \\
\hline Paranoide & 1.86 & .68 & -.47 & .64 & {$[-.17, .12]$} & .00 \\
\hline Sensibilidade Interpessoal & 1.89 & .76 & & & & \\
\hline \multicolumn{7}{|l|}{ Par 33} \\
\hline Paranoide & 1.86 & .68 & -8.39 & $.00^{*}$ & {$[-.78,-.41]$} & .41 \\
\hline Ansiedade & 2.46 & .83 & & & & \\
\hline \multicolumn{7}{|l|}{ Par 34} \\
\hline Obsessão-Compulsão & 2.27 & .78 & 5.73 & $.00 *$ & {$[.21, .56]$} & .24 \\
\hline Sensibilidade Interpessoal & 1.89 & .76 & & & & \\
\hline \multicolumn{7}{|l|}{ Par 35} \\
\hline Obsessão-Compulsão & 2.27 & .78 & -2.52 & $.01 *$ & {$[-.37, .01]$} & .06 \\
\hline Ansiedade & 2.46 & .83 & & & & \\
\hline \multicolumn{7}{|l|}{ Par 36} \\
\hline Sensibilidade Interpessoal & 1.89 & .76 & -8.64 & $.00 *$ & {$[-.74,-.40]$} & .63 \\
\hline Ansiedade & 2.47 & .83 & & & & \\
\hline
\end{tabular}

Nota: *As diferenças reportadas apresentam significância estatística de $p \leq .05$

\section{II.2.3.2.2. Diferenças na Sintomatologia psicopatológica em função das variáveis sociodemográficas: idade, estado civil e escolaridade}

Procuramos perceber em que medida a sintomatologia psicopatológica das doentes com cancro da mama da amostra diferiam quanto a variáveis sociodemográficas, testando assim H5 - espera-se que a sintomatologia psicopatológica das doentes com cancro da mama difira significativamente em função das variáveis sociodemográficas: idade, estado civil, escolaridade. 
Os testes multivariados não indicaram efeitos estatisticamente significativos entre a idade $\left[F(27,28)=.82, p=.73, \eta^{2}=.07\right]$ e o estado civil $[F(27,28)=.80, p=.75$, $\left.\eta^{2}=.07\right]$ e as dimensões da sintomatologia psicopatológica na amostra de doentes com cancro da mama estudadas. Apenas a escolaridade revelou efeito significativo na sintomatologia psicopatológica das doentes observadas $[F(27,28)=1.87, p=.01$, $\left.\eta^{2}=.15\right]$. Os teste post hoc demonstraram que a somatização é a dimensão sintomatológica que mais diferenças apresenta em função da escolaridade das doentes $\left[F(2,100)=4.47, p=.01, \eta^{2}=.12\right]$. A análise estatística demonstra que as doentes com cancro da mama que não frequentaram a escola $(\mathrm{M}=2.61, \mathrm{DP}=.59), p=.02$, IC $95 \%$ $[2.12,3.09]$ e que completaram o ensino básico $(\mathrm{M}=2.27 ; \mathrm{DP}=.72), p=.03$, IC 95\% $[2.10,2.43]$ apresentam valores significativamente superiores de somatização quando comparadas com as doentes com qualificações académicas superiores ( $\mathrm{M}=1.28$, $\mathrm{DP}=.63), \mathrm{IC} 95 \%[1.28,2.01]$.

Procuramos aprofundar o nosso estudo, tentando perceber se as variáveis sociodemográficas exerciam influência nos três índices de sintomatologia psicopatológica. Com esse intuito foram realizadas análises de variância univariada. Os resultados indicam que não existem efeitos estatisticamente significativos entre a idade $\left[F(3,100)=.67, \quad p=.57, \eta^{2}=.02\right]$, estado civil $\left[F(3,100)=.63, \quad p=.60, \eta^{2}=.02\right]$, escolaridade $\left[F(3,100)=2.49, p=.07, \eta^{2}=.07\right]$ e o $I G S$. O mesmo padrão foi verificado face ao ISP relativamente às mesmas variáveis: idade $\left[F(3,100)=.49, p=.70, \eta^{2}=.02\right]$, estado civil $\left[F(3,100)=.65, p=.59, \eta^{2}=.02\right]$ e escolaridade $[F(3,100)=1.04, p=.38$, $\left.\eta^{2}=.03\right]$. Por último, também não se registaram efeitos significativos nas variáveis idade $\left[F(3,100)=.33, p=.81, \eta^{2}=.01\right]$, estado civil $\left[F(3,100)=.67, p=.58, \eta^{2}=.02\right] \mathrm{e}$ escolaridade $\left[F(3,100)=.27, p=.84, \eta^{2}=.01\right]$ no que respeita ao TSP. Assim, tendo em conta os resultados verificados, a hipótese 5 não foi confirmada. 


\section{II.2.3.2.3. Diferenças na sintomatologia psicopatológica em função das variáveis clínicas: estadio, prognóstico, sintomas, tratamento e cirurgia}

Quisemos igualmente observar se a sintomatologia psicopatológica apresenta diferenças face às variáveis clínicas do curso da doença nas doentes com cancro da mama da amostra estudada, em ordem a testar H6 - postula-se que a sintomatologia psicopatológica difira significativamente em função das variáveis clínicas: estadio, prognóstico, sintomas, tratamento e cirurgia.

Os testes multivariados não encontraram efeitos estatisticamente significativos de nenhuma das variáveis clínicas nas dimensões de sintomas psicopatológicos, a saber: estadio $\left[F(18,17)=1.46, p=.11, \eta^{2}=.13\right]$, cirurgia $\left[F(27,24)=1.13, p=.31, \eta^{2}=.11\right]$, prognóstico $\left[F(18,18)=1.11, p=.34, \eta^{2}=.01\right]$, sintoma dor $[F(9,92)=.26, p=.98$, $\left.\eta^{2}=.03\right]$, sintoma astenia $\left[F(9,92)=1.70, p=.10, \eta^{2}=.14\right]$, sintoma diminuição $d a$ funcionalidade $\left[F(9,92)=1.13, p=.35, \eta^{2}=.10\right]$, outros sintomas $[F(9,92)=.21, p=.10$, $\left.\eta^{2}=.02\right]$

Procuramos também perceber se as variáveis clínicas influíam nos três índices de sintomas psicopatológicos. Os resultados obtidos na análise univariada foram semelhantes aos encontrados face às variáveis sociodemográficas, ou seja, nenhuma das variáveis clínicas, a saber: estadio $\left[F(2,94)=.36, \quad p=.70, \eta^{2}=.01\right]$, cirurgia $\left[F(3,85)=1.26, p=.30, \eta^{2}=.04\right]$, tratamento $\left[F(3,98)=2.32, p=.09, \eta^{2}=.07\right]$, prognóstico $\left[F(2,98)=.63, p=.54, \eta^{2}=.01\right]$, sintoma dor $\left[F(1,100)=.11, p=.75, \eta^{2}=.00\right]$, sintoma astenia $\left[F(1,100)=.30, p=.59, \eta^{2}=.00\right]$, sintoma diminuição da funcionalidade $[F(1$, 
$\left.100)=.86, p=.36, \eta^{2}=.01\right]$, outros sintomas $\left[F(1,100)=.21, p=.65, \eta^{2}=.00\right]$ tem efeitos significativos no IGS. O mesmo se verificou relativamente ao ISP e ao TSP. Também a hipótese 7 não obteve confirmação em função dos resultados encontrados.

\section{II.2.3.2.4. Relação entre a Experiência Subjetiva de Sofrimento na Doença e a Sintomatologia Psicopatológica das doentes com cancro da mama}

Por forma a pesquisar em que medida as dimensões do sofrimento avaliadas pelo IESSD de relacionam com as dimensões dos sintomas psicopatológicos avaliadas pelo BSI em doentes com cancro da mama, foi realizada análise correlacional bivariada.

Como podemos constatar na tabela 12, a análise estatística realizada permitiu verificar existência de relação positiva significativa entre todas as dimensões do IESSD e todas as dimensões do BSI, à exceção da dimensão experiências positivas de sofrimento, na qual foi apenas reportada relação significativa no sentido inverso com as dimensões psicopatológicas: somatização $(r=-.21, p<.05)$, depressão $(r=-.34,<.01)$, hostilidade $(r=-.25, p<.05)$, indice geral de sintomas $(r=-.25, p<.05)$, total de sintomas positivos $(r=-.20, p<.05)$, indice sintomas positivos $(r=-.20, p<.05)$. Indicando assim, que a níveis elevados de sofrimento físico, psicológico, socio-relacional e existencial correspondem níveis mais elevados de todos os sintomas psicopatológicos avaliados, bem como, respetivos índices de severidade. No que respeita às experiências positivas do sofrimento, a valores mais elevados associam-se valores menores de somatização, depressão, hostilidade e menor severidade dos sintomas nos três índices. Não foi encontrada relação estatisticamente significativa com a ansiedade, ansiedade fóbica, psicoticismo, ideação paranóide, obsessão compulsão e sensibilidade interpessoal. 
Acrescenta-se ainda, que correlações mais fortes, no caso do sofrimento físico, foram encontradas com os sintomas psicopatológicos somatização $(r=.61, p<.01)$, obsessão-compulsão $(r=.59, p=<.01)$ e com o $\operatorname{IGS}(r=.57, p<.01)$. No sofrimento psicológico as correlações com maior força registaram-se em relação à depressão $(r=.64, p<.01)$, ansiedade $(r=.63, p<.01)$ e nos três índices: IGS $(r=.69, p<.01)$, ISP e $\operatorname{TSP}(r=.59, p<.01)$. O sofrimento socio-relacional correlaciona-se com mais força com o psicoticismo $(r=.45, p<.01)$, obsessão-compulsão $(r=.44, p<.01)$, depressão $(r=42$, $p<.01)$, e com os três índices: IGS $(r=.48, p<.01), \operatorname{ISP}$ e $T S P(r=.41, p<.01)$. O sofrimento existencial apresenta forte correlação com o IGS $(r=.65, p<.01)$, obsessão compulsão $(\mathrm{r}=.59, \mathrm{p}<.01)$, e em igual força de significância com os índices ISP, TSP, sensibilidade interpessoal e depressão $(r=.56, p<.01)$. Para concluir, nas experiências positivas de sofrimento na doença a correlação mais forte é com a depressão $(r=-.34$, $p<.01)$. Desta feita, em função dos resultados obtidos, confirma-se a hipótese formulada.

Tabela 12

Matriz de correlação bivariada de Perason entre as Dimensões do IESSD e as Dimensões do BSI

\begin{tabular}{|c|c|c|c|c|c|}
\hline \multirow[b]{3}{*}{ Dimensões BSI } & \multicolumn{5}{|c|}{$N=104$} \\
\hline & \multicolumn{5}{|c|}{ Dimensões IESSD } \\
\hline & Físico & Psicológico & $\begin{array}{l}\text { Socio- } \\
\text { relacional }\end{array}$ & Existencial & $\begin{array}{l}\text { Experiências } \\
\text { Positivas }\end{array}$ \\
\hline Somatização & $.61 * *$ & $.49 * *$ & $.25 * *$ & $.46 * *$ & $-.21 *$ \\
\hline Depressão & $.48 * *$ & $.64 * *$ & $.42 * *$ & $.56 * *$ & $-.34 * *$ \\
\hline Ansiedade & $.47 * *$ & $.63 * *$ & $.41 * *$ & $.53 * *$ & -.17 \\
\hline Ansiedade Fóbica & $.34 * *$ & $.44 * *$ & $.22 * *$ & $.34 * *$ & -.02 \\
\hline Hostilidade & $.27 * *$ & $.38 * *$ & $.31 * *$ & $.41 * *$ & $-.21 *$ \\
\hline Psicoticismo & $.30 * *$ & $.47 * *$ & $.45 * *$ & $.47 * *$ & -.15 \\
\hline Ideação Paranóide & $.26 * *$ & $.41 * *$ & $.29 * *$ & $.36^{* *}$ & -.15 \\
\hline Obsessão Compulsão & $.59 * *$ & $.59 * *$ & $.44 * *$ & $.59 * *$ & -.13 \\
\hline Sensibilidade Interpessoal & $.35 * *$ & $.48 * *$ & $.38 * *$ & $.56 * *$ & -.12 \\
\hline$I G S$ & $.57 * *$ & $.69 * *$ & $.48 * *$ & $.65 * *$ & $-.25 *$ \\
\hline$I S P$ & $.45 * *$ & $.59 * *$ & $.41 * *$ & $.56 * *$ & $-.20 *$ \\
\hline$T S P$ & $.45^{* *}$ & $.59 * *$ & $.41 * *$ & $.56 * *$ & $-.20 *$ \\
\hline
\end{tabular}




\section{II.2.3.2.5. Efeito da Experiência Subjetiva de Sofrimento na Doença na severidade da Sintomatologia Psicopatológica}

Quisemos ainda pesquisar se a experiência subjetiva de sofrimento na doença pode contribuir para o agravamento dos sintomas psicopatológicos, testando assim $\mathrm{H} 7$ prevê-se que a experiência de sofrimento na doença contribui para o agravamento da severidade da sintomatologia psicopatológica. Com esse intuito foram efetuadas três regressões múltiplas standar, por forma a determinar qual o melhor preditor, entre as cinco dimensões do sofrimento relativamente a cada um dos índices de sintomas psicopatológicos. A predição do índice total de sintomas positivos a partir das dimensões do sofrimento físico, psicológico, socio-relacional, existencial e experiências positivas do sofrimento revelaram existência de modelo significativo $F(5,98)=14.35$, $p<.05$, explicando $42 \%$ da variância do índice total de sintomas positivos $\left(R^{2}=.42\right)$. Por sua vez, a análise dos coeficientes de regressão demonstrou que nenhum dos preditores por si eram estatisticamente significativos para o modelo testado, embora o contributo maior para a variância do índice de total de sintomas positivos seja dada pelo sofrimento existencial (beta=.23, $p>.05)$.

A mesma análise foi efetuada para avaliar o melhor preditor entre as dimensões do sofrimento face ao índice de sintomas positivos. A predição do índice de sintomas positivos indicou que o modelo é significativo para as cinco dimensões do sofrimento $F(5,98)=5.77, p<.05$, explicando $23 \%$ da variância do índice sintomas positivos $\left(R^{2}=\right.$ .23). No entanto, ficou demonstrado que nenhum dos preditores é estatisticamente significativo.

Por último, o mesmo procedimento estatístico foi realizado para investigar qual o melhor preditor de entre as cinco dimensões do sofrimento do índice geral de 
sintomas. Os resultados indicaram que o modelo é significativo $F(5.98)=21.72, p<.05$, explicando $53 \%$ da variância do índice geral de sintomas $\left(R^{2}=.53\right)$. A análise dos coeficientes revelou que apenas o sofrimento psicológico contribuiu com peso estatisticamente significativo para a variância do índice geral de sintomas (beta=.32, $p<.05)$. Face aos resultados apresentados, podemos afirmar que a hipótese 9 é parcialmente confirmada. Na tabela 13 podem ser consultados todos os resultados das análises efetuadas.

Tabela 13

Análise de regressão múltipla das cinco dimensões do sofrimento em função dos três indices de sintomas psicopatológicos

\begin{tabular}{|c|c|c|c|c|c|c|}
\hline & \multicolumn{6}{|c|}{$N=104$} \\
\hline & $R^{2}$ & $R^{2} \Delta$ & $P$ & $\boldsymbol{B}$ & SEB & $\beta$ \\
\hline \multicolumn{7}{|l|}{ TSP } \\
\hline Físico & .42 & .39 & .14 & 4.90 & 3.29 & .17 \\
\hline Psicológico & & & .27 & 5.21 & 4.70 & .18 \\
\hline Socio-relacional & & & .18 & 4.24 & 3.12 & .15 \\
\hline Existencial & & & .14 & 7.88 & 5.31 & .23 \\
\hline Experiências Positivas & & & .28 & -2.46 & -2.29 & -.09 \\
\hline \multicolumn{7}{|l|}{ ISP } \\
\hline Físico & .23 & .19 & .82 & -.16 & .67 & -.03 \\
\hline Psicológico & & & .14 & -1.40 & .95 & -.27 \\
\hline Socio-relacional & & & .22 & -.79 & .63 & -.16 \\
\hline Existencial & & & .92 & -.11 & 1.07 & -.02 \\
\hline Experiências Positivas & & & .09 & .79 & .46 & .16 \\
\hline \multicolumn{7}{|l|}{ IGS } \\
\hline Físico & .53 & .50 & .29 & .07 & .07 & .11 \\
\hline Psicológico & & & .03 & .21 & .09 & .32 \\
\hline Socio-relacional & & & .45 & .05 & .06 & .08 \\
\hline Existencial & & & .08 & .19 & .11 & .25 \\
\hline Experiências Positivas & & & .05 & -.09 & .05 & -.15 \\
\hline
\end{tabular}

\section{II.2.3.2.6. Perfil Psicológico das doentes com cancro da mama estudadas}

Por fim, finalizamos esta apresentação com a última hipótese de trabalho elaborada, H8 - espera- ser possível traçar um perfil psicológico das doentes com cancro da mama estudadas. Com base na análise anteriormente efetuadas e nos 
resultados encontrados, na tentativa de conhecer melhor o funcionamento psicológico no que respeita à experiência subjetiva de sofrimento na doença e sintomatologia psicopatológica decorrente do processo de doença, procurámos traçar um perfil psicológico das doentes com cancro da mama participantes no estudo. Para o efeito procedeu-se à construção clusters relativos à severidade da sintomatologia psicopatológica, apoiando-se a análise de clusters no método combinatório, especificando os centróides a partir do método hierárquico (Ward's method e Squared Euclidean Distance), que posteriormente foram o suporte para a aplicação do método Não-Hierárquico (K-Means Cluster Analysis). Foi apenas testada uma solução em três grupos, isto é, a possibilidade da existência de grupos com severidade baixa, moderada e elevada, tendo em conta a literatura revisada e a experiência clínica com doentes com cancro da mama.

Os três padrões resultantes foram validados com recurso a ANOVAs (One-way). Os resultados confirmaram a hipótese dos três grupos sintomatológicos.

Na tabela 14 encontramos as médias e desvio padrão relativamente aos três grupos de clusters de severidade efetuados.

\section{Tabela 14}

Diferenças de médias e desvio padrão dos clusters de severidade

\begin{tabular}{lccc}
\hline & \multicolumn{3}{c}{$\boldsymbol{N = 1 0 4}$} \\
\cline { 2 - 4 } Clusters BSI & $\boldsymbol{N}$ & $\boldsymbol{M}$ & $\boldsymbol{D P}$ \\
\cline { 2 - 4 } Baixa severidade & 57 & 1.84 & .56 \\
Severidade média & 38 & 2.58 & .62 \\
Severidade elevada & 9 & 3.05 & .52 \\
\hline
\end{tabular}

A análise estatística revelou que o modelo testado é significativo nos três grupos de severidade estudados em todas as dimensões de sintomas psicopatológicos [somatização $F(2,101)=29.10, p=.00, \eta^{2}=.37$, obsessão compulsão $F(2,101)=60.75$, $p=.00, \eta^{2}=.55$, sensibilidade interpessoal $F(2,101)=67.84, p=.00, \eta^{2}=.57$, depressão $F(2,101)=78.48, p=.00, \eta^{2}=.61$, ansiedade $F(2,101)=72.76, p=.00, \eta^{2}=.60$, hostilidade 
$F(2,101)=30.56, p=.00, \eta^{2}=.61$, ansiedade fóbica $F(2,101)=53.10, p=.00, \eta^{2}=.51$, paranoide $F(2,101)=30.02, p=.00, \eta^{2}=.37$ e psicoticismo $F(2,101)=45.39, p=.00$, $\left.\eta^{2}=.47\right]$.

Os testes post hoc indicaram que as doentes com cancro da mama estudas apresentam diferenças de médias estatisticamente significativas nos três grupos de severidade nas nove dimensões de sintomas psicopatológicos. Os três grupos diferem significativamente entre si nos sintomas obsessão-compulsão, depressão, ansiedade e sensibilidade interpessoal ( $p=.00$ ), sendo as doentes da amostra do grupo da severidade elevada que registam valores superiores nestes sintomas $[(\mathrm{M}=3.43, \mathrm{DP}=.18),(\mathrm{M}=3.37$, $\mathrm{DP}=.18),(\mathrm{M}=3.22, \mathrm{DP}=.15),(\mathrm{M}=3.17, \mathrm{DP}=.17)$, respetivamente] comparativamente com as do grupo severidade média [(M=2.58, DP=.09), $(\mathrm{M}=2.58, \mathrm{DP}=.09),(\mathrm{M}=2.43$, $\mathrm{DP}=.07),(\mathrm{M}=2.30, \mathrm{DP}=.08)$, respetivamente] e as do grupo da baixa severidade $[(\mathrm{M}=1.69, \quad \mathrm{DP}=.07), \quad(\mathrm{M}=1,49, \quad \mathrm{DP}=.07), \quad(\mathrm{M}=1.60, \quad \mathrm{DP}=.06), \quad(\mathrm{M}=1.41, \quad \mathrm{DP}=07)$, respetivamente]. A tabela 15 apresenta a análise de resultados efetuada.

Tabela 15

Clusters de severidade relativos às dimensões dos sintomas psicopatológicos

\begin{tabular}{|c|c|c|c|c|c|c|c|c|c|c|c|}
\hline \multirow[b]{4}{*}{$S P$} & \multicolumn{10}{|c|}{ Clusters Severidade } & \multirow[b]{4}{*}{$\boldsymbol{P}$} \\
\hline & \multicolumn{4}{|c|}{1} & \multicolumn{2}{|c|}{2} & \multicolumn{3}{|c|}{3} & & \\
\hline & \multicolumn{4}{|c|}{$95 \%$} & \multicolumn{2}{|r|}{$95 \%$} & \multicolumn{4}{|c|}{$95 \%$} & \\
\hline & $M$ & $D P$ & $I C$ & $M$ & $D P$ & $I C$ & $M$ & $D P$ & $I C$ & Dif. & \\
\hline $\mathrm{S}$ & 1.85 & .08 & [1.69-1.98] & 2.58 & .09 & {$[2.41-2.78]$} & 3.05 & .19 & {$[2.67-3.43]$} & $1<2,3$ & .00 \\
\hline \multirow[t]{2}{*}{$\mathrm{OC}$} & 1.69 & .07 & [1.56-1.83] & 2.58 & .09 & {$[2.41-2.75]$} & 3.43 & .18 & [3.09-3.77] & $1<2,3$ & .00 \\
\hline & & & & & & & & & & $2<3$ & .00 \\
\hline \multirow[t]{2}{*}{ SI } & 1.41 & .07 & [1.28-1.54] & 2.30 & .08 & {$[2.14-2.47]$} & 3.17 & .17 & [2.83-3.58] & $1<2,3$ & .00 \\
\hline & & & & & & & & & & $2<3$ & .00 \\
\hline \multirow[t]{2}{*}{ D } & 1.49 & .07 & [1.35-1.63] & 2.58 & .09 & [2.41-2.75] & 3.37 & .18 & [3.02-3-72] & $1<2,3$ & .00 \\
\hline & & & & & & & & & & $2<3$ & .00 \\
\hline \multirow[t]{2}{*}{ A } & 1.60 & .06 & [1.48-1.72] & 2.43 & .07 & {$[2.29-2.58]$} & 3.22 & .15 & [2.93-3.52] & $1<2,3$ & .00 \\
\hline & & & & & & & & & & $2<3$ & .00 \\
\hline $\mathrm{H}$ & 1.49 & .06 & [1.38-1.60] & 2.10 & .07 & [1.96-2.23] & 2.33 & .14 & {$[2.05-2.62]$} & $1<2,3$ & .00 \\
\hline \multirow[t]{2}{*}{$\mathrm{AF}$} & 1.31 & .06 & {$[1.20-1.42]$} & 1.77 & .07 & [1.63-1.91] & 2.82 & .14 & [2.54-3.10] & $1<2,3$ & .00 \\
\hline & & & & & & & & & & $2<3$ & .00 \\
\hline \multirow[t]{2}{*}{$\mathrm{Pa}$} & 1.52 & .07 & [1.38-1.67] & 2.15 & .09 & {$[1.97-2.32]$} & 2.80 & .18 & {$[2.16-2.44]$} & $1<2,3$ & .00 \\
\hline & 131 & 06 & {$[1,18-143]$} & 183 & 08 & {$\left[\begin{array}{ll}68 & 1 \\
0 & 08]\end{array}\right.$} & 280 & & {$[240-311]$} & $\begin{array}{l}2<3 \\
1<23\end{array}$ & .01 \\
\hline Ps & 1.01 & .00 & {$[1.10-1.4 J]$} & $1.0 \mathrm{~J}$ & .00 & {$[1.00-1.90]$} & 2.00 & .17 & {$[2.45-5.11]$} & $2<3$ & .00 \\
\hline
\end{tabular}

Nota: 1. baixa severidade, 2. severidade média, 3. severidade alta; Dif. sentido das diferenças; SP. sintomas psicopatológicos; S. somatização; OC.obsessão-compulsão; SI. Sensibilidade interpessoal; D.depressão; A.ansiedade; H. hostilidade; AF.ansiedade fóbica; Pa. Paranoia; Ps psicoticismo; $p<.05$ 
Na tentativa de clarificar os resultados obtidos no sentido de traçar um perfil psicológico das doentes com cancro da mama estudadas no que refere à sintomatologia psicopatológica, como podemos constatar no gráfico 13, as doentes da amostra apresentam severidade mais elevada nos sintomas obsessão-compulão, depressão, ansiedade e sensibilidade interpessoal. A hostilidade, paranoia, ansiedade fóbica $\mathrm{e}$ psicoticismo, são os sintomas que registam menor severidade nas doentes.

\section{Gráfico 13}

Distribuição dos clusters de severidade pelas dimensões dos sintomas psicopatológicos

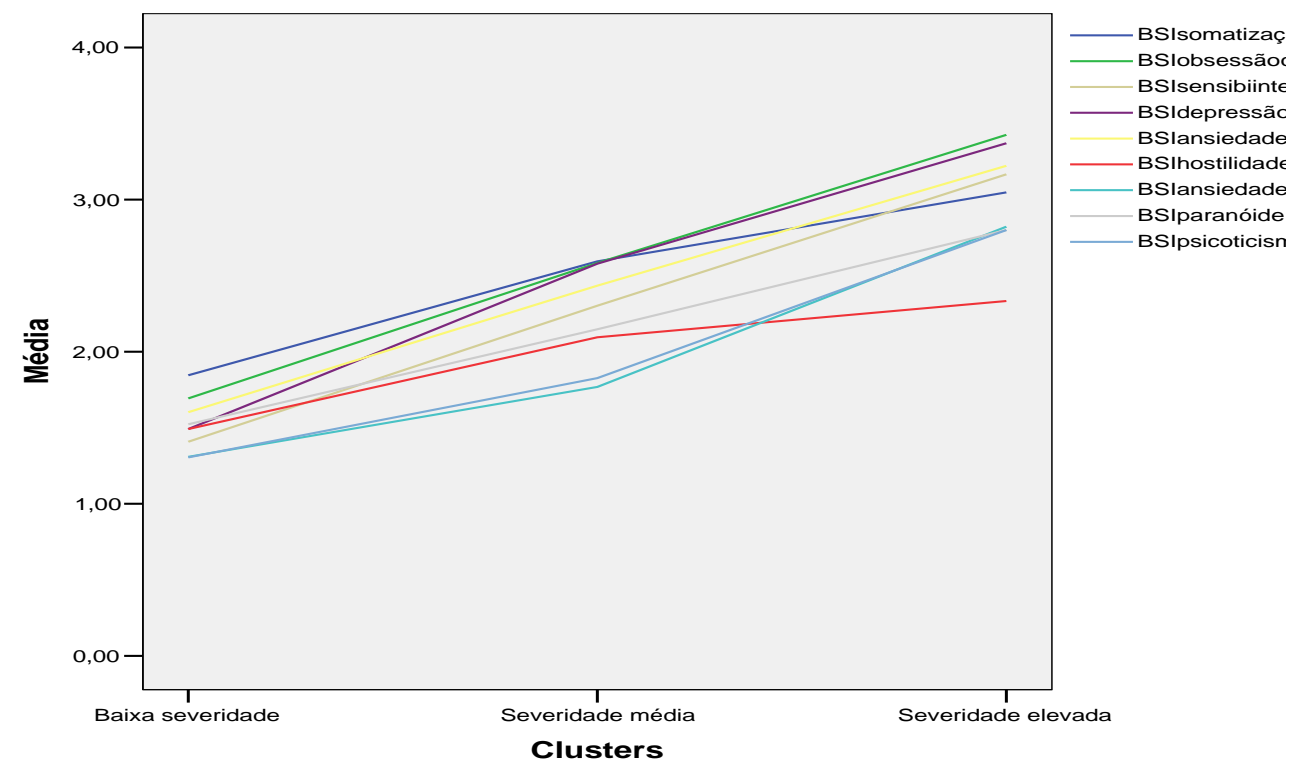

No que respeita aos grupos de clusters do sofrimento, o modelo revelou-se igualmente estatisticamente significativo $\left[F(10,196)=7.39, p=.00, \eta^{2}=.27\right]$. Ficou demonstrada a existência de diferenças significativas nos três grupos de severidade em todas as dimensões do sofrimento nas doentes com cancro da mama observadas, a saber: sofrimento físico $\left[F(2,101)=21.43, p=.00, \eta^{2}=.30\right]$, sofrimento psicológico $[\mathrm{F}(2$, $\left.101)=37.70, p=.00, \eta^{2}=.43\right]$, sofrimento socio-relacional $[F(2,101)=12.19, p=.00$, 
$\left.\eta^{2}=.19\right]$, sofrimento existencial $\left[F(2,101)=25.51, p=.00, \eta^{2}=.34\right]$ e experiências positivas de sofrimento na doença $\left[F(2,101)=3.29, p=.04, \eta^{2}=.06\right]$.

Os testes post hoc revelaram diferenças significativas entre os grupos de severidade em todas as dimensões do sofrimento. Analisando a tabela 16, podemos verificar que nas doentes da amostra o sofrimento socio-relacional atinge valores mais expressivos no grupo de severidade elevada $(\mathrm{M}=3.89, \mathrm{DP}=.26)$ quando comparado com os grupos de severidade moderada $(\mathrm{M}=3.03, \mathrm{DP}=.13)$ e baixa $(\mathrm{M}=2.58, \mathrm{DP}=.11)$, sendo esta diferença estatisticamente significativa entre os três grupos $(p=.00, p=.03, p=.02$, respetivamente). O mesmo padrão de resultados foi verificado relativamente ao sofrimento psicológico, tendo-se registado valores superiores no grupo das doentes com severidade elevada $(\mathrm{M}=3.89, \mathrm{DP}=.21)$ que no grupo das doentes com severidade moderada $(\mathrm{M}=3.12, \mathrm{DP}=.10)$ e baixa $(\mathrm{M}=2.10, \mathrm{DP}=.08)$, sendo esta diferença igualmente significativa $(p=.00)$. Por último, também o sofrimento existencial atinge valores superiores nas doentes com cancro da mama do grupo de severidade elevada $(\mathrm{M}=3.24, \mathrm{DP}=.26)$ que nos grupos de severidade baixa $(\mathrm{M}=1.99, \mathrm{DP}=.08)$ e moderada $(\mathrm{M}=2.56, \mathrm{DP}=.10)$, sendo esta diferença significativa entre os três grupos $(p=.00$, $p=.04)$. No caso das experiências positivas de sofrimento na doença, são as doentes com cancro da mama do grupo de baixa severidade que apresentam valores mais elevados $(\mathrm{M}=3.03, \mathrm{DP}=.12)$ quando comparadas com as de severidade moderada $(\mathrm{M}=2.56, \mathrm{DP}=.14)$, sendo a diferença estatisticamente significativa $(p=.04)$. 


\section{Tabela 16}

Clusters de severidade relativos às dimensões do sofrimento

\begin{tabular}{|c|c|c|c|c|c|c|c|c|c|c|c|}
\hline \multirow[b]{4}{*}{$D S$} & \multicolumn{10}{|c|}{ Clusters Severidade } & \multirow[b]{4}{*}{$P$} \\
\hline & \multicolumn{4}{|c|}{1} & \multicolumn{2}{|c|}{2} & \multicolumn{3}{|c|}{3} & & \\
\hline & & & $95 \%$ & & & $95 \%$ & & & $95 \%$ & & \\
\hline & $M$ & $D P$ & $I C$ & $M$ & $D P$ & $I C$ & $M$ & $D P$ & $I C$ & Dif. & \\
\hline $\mathrm{F}$ & 1.88 & .10 & {$[1.70-2.07]$} & 2.73 & .12 & {$[2.50-296]$} & 3.06 & .24 & {$[2.58-3.53]$} & $1<2,3$ & .00 \\
\hline $\mathrm{P}$ & 2.10 & .08 & {$[1.94-2.27]$} & 3.12 & .10 & [2.91-3.32] & 3.40 & .21 & [2.98-3-82] & $1<2,3$ & .00 \\
\hline SR & 2.58 & .11 & {$[2.37-278]$} & 3.03 & .13 & {$[2.78-3.28]$} & 3.89 & .26 & {$[2.37-4.41]$} & $1<2,3$ & .00 \\
\hline $\mathrm{E}$ & 1.99 & .08 & {$[1.83-2.15]$} & 2.67 & .10 & {$[2.48-2.86]$} & 3.24 & .20 & {$[2.85-3.64]$} & $\begin{array}{c}1<2,3 \\
2<3\end{array}$ & .00 \\
\hline EPS & 3.03 & .12 & {$[2.80-3.26]$} & 2.56 & .14 & {$[2.29-2.84]$} & 2.82. & .29 & {$[2.25-3.40]$} & $1>2$ & .04 \\
\hline
\end{tabular}

Em ordem a clarificar os resultados encontrados no que diz respeito ao perfil psicológico das doentes com cancro da mama observadas relativamente à experiência de sofrimento na doença, como podemos constatar no gráfico 14, as doentes com cancro da mama experimentam com maior severidade o sofrimento socio-relacional, seguido do sofrimento psicológico e existencial, em terceiro lugar. As experiências positivas de sofrimento face à doença não se associam a severidade uma vez que constituem uma variável positiva do sofrimento na doença. 


\section{Gráfico 14}

Distribuição dos clusters de severidade pelas cinco dimensões do sofrimento

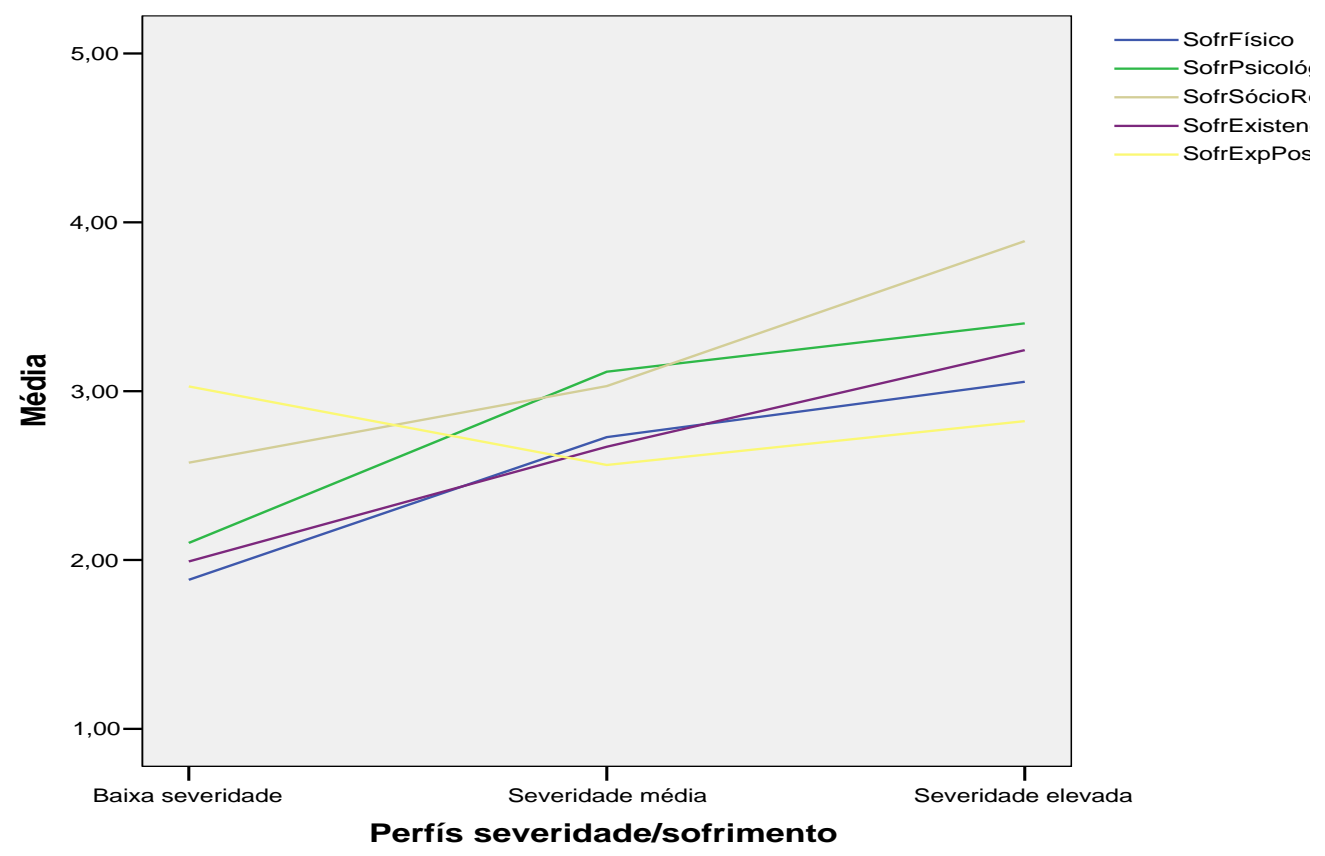




\section{DISCUSSÃO DOS RESULTADOS}

"Como costuma acontecer nas descobertas médicas, as melhores pesquisas baseiam-se em pesquisas já existentes".

(Dr. Sanjay Gupta, 2010, p. 34)

O presente trabalho teve com propósito principal estudar a experiência subjetiva de sofrimento na doença e a sintomatologia psicopatológica decorrentes do processo de adoecimento numa amostra de mulheres com cancro da mama. No sentido de perceber, enquanto objetivos específicos, quais as dimensões do sofrimento mais afetadas, e qual o contributo das variáveis sociodemográficas e clínicas para a variabilidade da experiência de sofrimento; qual a sintomatologia psicopatológica mais prevalente na amostra estudada, a sua variabilidade em função das variáveis clínicas e sociodemográficas. Pretendeu-se ainda pesquisar se as variáveis sofrimento e sintomatologia psicológica se relacionam, e por último, com base nos dados recolhidos traçar um perfil psicológico das doentes com cancro da mama estudadas. Passamos então a discutir os resultados encontrados em função da literatura consultada e das hipóteses levantadas. A concluir o capítulo refletimos sobre as limitações encontradas no nosso estudo, e finalizamos tecendo algumas considerações e sugestões face a trabalhos futuros.

Iniciamos a discussão dos resultados, começando por refletir sobre o perfil sociodemográfico e clínico das doentes com cancro da mama participantes no estudo, tido como importante na identidade social e clínica deste grupo de doentes, mas também 
na relação com as variáveis psicológicas empíricas a testar. No que respeita ao perfil sociodemográfico, à exceção da idade, as restantes variáveis revelam bastante homogeneidade. A amostra em estudo é bastante transversal em termos de faixa etária, abrangendo três grupos de idades (jovens adultos, adultos maduros, velhos), pertencentes aos ciclos da vida adultícia e velhice, conferindo assim, diversidade cronológica à população em estudo. Podendo explicar per si, a variabilidade de resultados face às restantes variáveis empíricas. Contudo, a média de idade de 55.22 anos, encontra-se dentro dos grupos etários onde se registam maiores taxas de prevalência do cancro da mama na Região Norte do país, segundo o Registo Oncológico Regional (IPOP, 2008; 2009; 2011). Enquadram-se igualmente no padrão etário verificado em grande parte dos estudos realizados em Portugal, ainda que utilizando amostra recolhidas no centros urbanos do litoral (Baltar, Pais-Ribeiro \& Lopes, 2001; Fernandes, 2009; Patrão \& Leal, 2004; Rolim, et al., 2007; Tapadinhas, 2004), parecendo indicar que o cancro da mama é uma doença que atinge, em média, mulheres na fase madura da idade adulta do ciclo vital.

No entanto, ao longo da recolha da amostra foi possível constatar o aumento do número de casos novos em mulheres jovens (<30 e os 40 anos de idade). Tendência que começa a ser verificada desde 2006, também na Região do Norte do país (IPOP, 2008; 2009; 2011). Não obstante, não possuímos informação suficientemente credível para justificar o facto.

A homogeneidade da amostra observa-se ao nível do local de residência, todas as participantes residem na Província de Trás-os-Montes e Alto Douro, geograficamente no interior norte do país, na sua maioria no distrito de Vila Real. A generalidade são casadas, possuem baixas qualificações académicas $\left(1^{\circ}\right.$ ciclo do ensino básico completo ou incompleto), são domésticas e encontram-se pouco ativas a nível ocupacional (em 
maior número são reformadas, em segundo lugar estão de baixa/atestado médico), e pertencem a agregados familiares alargados (cônjuges filhos, em alguns casos, pais e sogros). As características da variável local de residência poderão constituir limitação à generalização dos resultados obtidos, nomeadamente, em comparação com as doentes com cancro da mama do litoral. Todavia, estudos comparativos entre amostras de doentes oncológicas da mama residentes em contexto rural e urbano, poderia reunir interesse científico. Bem como, a escolaridade e atividade profissional. Resultados diferentes poderão ser encontrados em doentes com habilitações académicas mais diferenciadas e profissões de maior exigência intelectual.

O perfil clínico apresenta maior variabilidade no que respeita ao tempo de diagnóstico e estadio da doença. As doentes da amostra distribuem-se por quatro grupos, diagnóstico há mais de dois anos, fase de sobrevivência; diagnóstico entre um ano e dois, fase final de tratamentos; diagnóstico há menos de um ano, fase de tratamentos; e diagnóstico há menos de seis meses, fase de diagnóstico e início dos tratamentos. Já relativamente ao estadio da doença cirurgia, tratamentos e prognóstico, a amostra é mais homogénea. Na maioria das doentes a doença encontra-se a nível locoregional, em maior número encontram-se a realizar hormonoterapia ou imunoterapia; a generalidade é mastectomizada, o prognóstico é razoável na maioria, também em maior número queixam-se essencialmente de astenia, sintoma decorrente da situação de doença e dos tratamentos. Segundo a literatura consultada as variáveis clínicas influenciam a experiência de sofrimento na doença e a sintomatologia psicopatológica. Por isso, foram consideradas pertinentes no presente trabalho. Mais à frente comentaremos se essa influência foi verificada tendo em conta os resultados obtidos, em função das hipóteses colocadas. 
No que se refere às variáveis empíricas. Como previa a $\mathrm{H} 1$, o sofrimento acompanha a experiência de doença das doentes com cancro da mama estudadas. $\mathrm{O}$ sofrimento é maior a nível socio-relacional, seguindo-se, em segundo lugar, do sofrimento psicológico, sendo essa diferença estatisticamente significativa. Assim, os resultados parecem indicar que a experiência de doença provoca nas mulheres com cancro da mama da amostra importantes alterações afetivo-relacionais e alterações sócio-laborais; alterações emocionais, cognitivas, comportamentais e na identidade pessoal, mais expressivas e valorativas na sua representação e avaliação subjetiva, do que a dor e desconforto físico ou preocupações existenciais.

Os resultados apontam assim, como indica Bayés $\left(1998^{\text {b }}\right.$, que o sofrimento não se limita à dimensão física, estendendo-se a outras dimensões da pessoa igualmente significativas. Embora menos reconhecidas e atendidas na prestação dos cuidados de saúde (McIntyre, 2004). Perda e sofrimento encontram-se relacionados. A experiência de doença acarreta perdas várias (McIntyre, 2004). No caso das doentes avaliadas, as perdas parecem fazer-se sentir essencialmente ao nível da relação corporal, corporalidade, sexualidade, relacionamentos interpessoais, íntimos e afetivos, desempenho de atividades e papeis profissionais, ocupacionais, entre outros papeis sociais. Explicava Cassell (1982), não são os factos que causam sofrimento, mas sim o significado atribuído aos mesmos. A carga afetiva associada às significações atribuídas às perdas, despoletam, por sua vez, sofrimento psicológico (McIntyre, 2004). Como indicam outros estudos, nos quais o sofrimento socio-relacional e psicológico são os que apresentam intensidade mais elevada (Costa, Jiménez \& Pais-Ribeiro, 2010; Pereira, 2008; Ribeiro, Cunha \& Pereira, 2012; Silva 2008).

Não obstante, a experiência subjetiva de sofrimento na doença em mulheres com cancro da mama encontra-se pouco documentada bibliograficamente, por conseguinte, 
os dados são escassos para comparação. Nesse ponto, acreditamos residir, precisamente, a originalidade e pertinência do nosso trabalho, enquanto contributo para o estudo do sofrimento na doença no contexto da saúde/doença oncológica.

As doentes com cancro da mama avaliadas revelam ainda índices significativos de experiências positivas de sofrimento na doença, sendo a terceira dimensão do sofrimento a conseguir as médias mais altas. Apesar de experienciarem sofrimento socio-relacional e psicológico, as doentes estudadas denotam conseguir encontrar um sentido positivo na experiência de doença. O sofrimento existencial na doença, comparativamente com a dor e com o sofrimento psicopatológico oferece possibilidades de representação positiva da doença, no encontro de novos significados para a vida e reconstrução do self (McIntyre, 1995 ), ou seja, de crescimento na doença. Assim, a doença, à semelhança de outros acontecimentos difíceis de vida, é suscetível de promover oportunidade de crescimento (Amado, 2007; Bonino, 2007; Didion, 2006; Franklin, 1977/2008; Kubler_Ross, 1977/2008; Lesser, 2009; Mann, 2009; Pausch, 2012; Reiss, 2012). Podemos então dizer, que a experiência positiva de sofrimento na doença em doentes com cancro da mama pode ser vivida e representada enquanto experiência de transformação pessoal (Coward, 1990; Patrão, Leal \& Maroco, 2008; Rehnsfeld, Lindholm \& Hamrin, 2002; Thomas-maclean, 2004; Wenzel \& Stevens, 2008). As experiências de sofrimento na doença podem ainda ser associadas ao crescimento pós traumático na doença (Ching, et al., 2009; Krikorian, et al., 2011;Pinto, et al., 2009). Por outro lado, ao se associarem a estratégias de coping do tipo "espírito de luta", diminuem a intensidade do sofrimento e potenciam melhor ajustamento ao processo de doença, na medida que um sentido positivo lhe é atribuído (Gameiro, 1999). Nas significações positivas atribuídas à experiência de doença, as crenças religiosas parecem ter aqui um papel importante. A religiosidade é uma característica 
cultural das mulheres do interior norte do país. Encontrando-se intimamente relacionada com a dimensão existencial e espiritual da vida. Por conseguinte, nomeadamente nas doentes mais velhas, como foi observado narrativamente enquanto respondiam ao protocolo de investigação, muitos acontecimentos de vida são atribuídos à providência divina. Nelas muitas doentes encontram explicação para o acontecimento doença e força na luta a travar contra ela. Deixamos alguns testemunhos: "Após o aparecimento do cancro da mama, a minha vida espiritual aumentou, pedindo a Deus que me curasse, $e$ aceitei a minha doença" (62 anos, mastectomizada); "Aceitei o que me aconteceu com uma enorme vontade de vencer, o que me aproximou ainda mais de Deus" (67 anos, tumorectomizada); "Apesar de já ser uma pessoa de fé, esta doença veio aumentar a minha fé e comecei a pensar mais na vida" (51 anos, tumorectomizada); "Fiquei mais forte ao pensar que Deus me melhorou" (46 anos, tumorectomizada); "Deus pôs-me à prova para saber se tinha forças para enfrentar a doença" (42 anos, mastectomizada). A ligação a Deus aparece na trajetória da doença como uma negociação em prol da cura e superação do sofrimento (Aquino \& Zago, 2007). O recurso a Deus em momentos de aflição e desespero é comum a todos os seres humanos, mesmo naqueles que se dizem descrentes, como demonstra (Bering, 2011). Apesar dos médicos raramente abordarem a religiosidade com os seus doentes, esta vontade é partilhada por muitos deles (Anadanajah \& Height, 2001).

Como defende Sarró (2009), sofrimento e religião sempre andaram lada a lado, por isso é tão reforçada em antropologia médica. Como tal, esta relação deveria ser mais respeitada no contexto da saúde/doença. Explorar as potencialidades desta variável no processo de lidar com o sofrimento, na representação e resignificação da experiência e crescimento pessoal na de doença, parece-nos uma sugestão igualmente benéfica e profícua a considerar em trabalhos futuros com doentes oncológicas da mama. 
Ainda no âmbito do estudo do sofrimento nas doentes com cancro da mama participantes na investigação, procuramos investigar se o sofrimento apresentava variabilidade em função das variáveis sociodemográficas $(\mathrm{H} 2)$. Segundo os resultados obtidos, as características sociodemográficas não influenciam a experiência de sofrimento. Apenas a escolaridade exerce influência na experiência de sofrimento na doença, em todas as dimensões à exceção do sofrimento socio-relacional. As doentes com habilitações superiores experimentam menos sofrimento físico, menos sofrimento psicológico, menos sofrimento existencial, e mais experiências positivas de sofrimento na doença comparativamente com as doentes que possuem habilitações mais reduzidas ( $1^{\circ}$ ciclo do ensino básico). No entanto, a escolaridade não influi no sofrimento sóciorelacional, esse encontra-se presente em todas as doentes. A dimensão socio-relacional do sofrimento parece ser assim transversal a todas as doentes, independentemente das habilitações académicas. Constituindo a dimensão que mais sofrimento provoca na amostra estudada.

A escolaridade parece assim ser uma variável diferenciadora na forma como o processo de doença é enfrentado. A frequência do ensino superior poderá fornecer às doentes competências ao nível da forma de lidar com a situação de doença (coping), minimizando a experiência de sofrimento na doença e atribuindo uma representação mais positiva a essa mesma experiência, podendo ser considerada como possivelmente potenciadora da aprendizagem e crescimento na doença e resignificação mais positiva da experiência da mesma. Já nas doentes com menos habilitações, a intensidade superior do sofrimento poderá ser explicada pela escassez de recursos intelectuais, suscetíveis de influir nas cognições de doença, na forma como esta é representada e pelas estratégias utilizadas para lhe fazer frente. O sentido que atribuem ao acontecimento doença na trajetória de vida. Cognições e estratégias centradas no "fatalismo" foram referidas por 
algumas doentes aquando da resposta aos questionários, "foi castigo", "Deus quis assim"; "tive pouca sorte".

Contrariamente ao que seria de esperar, tendo em conta $\mathrm{H} 3$, não ficou comprovado que as variáveis clínicas influenciam a experiência subjetiva de sofrimento na doença nas mulheres com cancro da mama estudadas, como indica a literatura sobre sofrimento consultada (Araújo-Soares \& McIntyre, 2000; Bento, 2000; Gameiro, 1999; McIntyre, 2004; Shofield et al., 2003).

Assim, segundo os resultados do nosso estudo, o sofrimento na doença na amostra estudada parece não apresentar variações em função do tempo de diagnóstico, estadio da doença, tratamentos, sintomas e prognóstico. Seria expectável, que a fase inicial do diagnóstico suscitasse maior sofrimento psicológico. Estadios de doença mais avançados e pior prognóstico se associassem a mais sofrimento psicológico e existencial. Durante os tratamentos, as doentes em quimioterapia experimentassem maior sofrimento físico, psicológico e socio-relacional. No que respeita à sintomatologia, seria previsível que doentes com dor experimentassem mais sofrimento físico e doentes com astenia maior sofrimento psicológico e socio-relacional. No entanto, tal não foi verificado.

Apenas a diminuição da funcionalidade tem efeitos estatisticamente significativos no sofrimento físico e nas experiências positivas. Ou seja, a perda de capacidades físicas decorrentes da doença e dos tratamentos, a saber mastectomia (se radical, perda de força no braço do lado da mama retirada) e quimioterapia (náuseas, vómitos, cefaleias, dores no corpo, fraqueza muscular, entre outros), limitam a autonomia funcional, provocando sofrimento físico. Esta condicionante poderá comprometer o desenvolvimento de experiências e expectativas mais positivas 
relativamente à experiência de doença. No caso das mulheres com cancro da mama estudadas, as limitações na funcionalidade poderão ter maior impacto, dadas as características sociodemográficas e culturais da amostra. Pois uma parte representativa das doentes é doméstica, dedicam a sua vida ao lar e à família. Quando são impedidas ou limitadas em o fazer, o significado da vida pode ficar comprometido.

O tipo de cirurgia parece exercer influência significativa nas experiências positivas de sofrimento na doença. As doentes que não realizaram cirurgia encontram-se mais positivas face à experiência de doença. $\mathrm{O}$ facto poderá ser explicado por eventuais crenças associadas a menor gravidade da doença, alimentadas pelas doentes que não realizaram cirurgia. Por outro lado, é bem conhecido o impacto psicossexual da mastectomia, nas doentes com cancro da mama. Ao serem poupadas da mutilação da mama, conservam a imagem corporal, sexualidade, feminilidade, auto-estima, e a qualidade dos relacionamentos íntimos e sociais. Isso potencia uma atitude mais positiva da experiência de doença. Dada a importância que a mama assume na feminilidade, maternidade e sexualidade na mulher (Dias et al., 2001; Rodrigues et al., 2012, Rojas-May, 2007; Santos, 1999; Sendersky et al, 2002).

A concluir a discussão dos resultados face à avaliação e caracterização da experiência de sofrimento na doença em mulheres com cancro da mama da amostra em estudo. Importa salientar, que mesmo nas dimensões do sofrimento onde foram obtidos índices mais elevados, o sofrimento não assumiu o carácter de intensidade severa. Acreditando-se assim, que o sofrimento enquanto experiência vivencial “despatologizada" que acompanha a trajetória de doença, poderá ter sido minimizado na amostra estudada, dadas as características do centro de oncologia no qual as doentes fazem tratamentos. Onde os cuidados de saúde prestados às doentes, segundo podemos observar no trabalho de campo efetuado, são centrados nos doentes e assentam na 
perspetiva humanizada dos cuidados. Sendo por nós verificado o bom relacionamento das doentes com os profissionais de saúde, equipa de administrativos e auxiliares de enfermagem, o reconhecimento e a satisfação das doentes com o mesmo. Atender e aliviar o sofrimento é assim condição essencial dos cuidados em saúde, da responsabilidade de tosos os profissionais de saúde, sem exceção (Bayés, 1998 ${ }^{a}, 2^{2003^{b}}$, 2009, 2010; Jairo et al., 2008; McIntyre, 1995a). A minimização do sofrimento na doença passa pela relação doentes-profissionais de saúde, baseada na comunicação eficaz (Bayés, 2004; Freitas \& Sousa, 2004; Pereira, 2008; McIntyre, 1995ª), no fornecimento de informação clara sobre a doença e tratamentos e esclarecimento de dúvidas (Gameiro, 1999; McIntyre, 1995a; Pereira, 2008), e pela diminuição dos tempos de espera dos doentes (Bayés, 2003 ${ }^{a}$. A observação, segundo Bayés $\left(1998^{a}\right)$ é o melhor instruemnto de estudo para conhecer a realidade do sofrimento no contexto hospitalar. Por esse motivo, quisemos incluí-la no nosso trabalho, por forma a completar e enriquecer a visão quantitativa da investigação do sofrimento em doentes com cancro da mama.

Tempo agora para nos debruçarmos sobre a avaliação da sintomatologia psicopatológica em doentes com cancro da mama. Como prevíamos, confirmando-se a H4, as participantes da amostra apresentam sintomatológicos psicopatológica, não obstante, esta não apresenta relevância clínica. Os sintomas psicopatológicos mais prevalentes foram: a ansiedade, registando o valor mais expressivo, seguido da obsessão-compulsão, somatização, e da depressão em quarto lugar. Confirma-se, como referido pela literatura revisada, que as mulheres com cancro da mama avaliadas apresentam dois dos quadros sintomatológicos mais frequentes na população oncológica em geral (Akechi et al, 2004; Mitchell et al, 2012; Raison \& Miller, 2003; Ritterband \& Spielberger, 2001; Tavares, 1999; Vasquez et al., 1998) e na da mama em particular 
(Eping-Jordan et al, 1999; Fernandes \& McIntyre, 2002; Graner et al, 2008; Green et al, 2000; Golden-Kreutz \& Anderson, 2008; Jacobs \& Bovassos, 2000; Moreira et al, 2008; Payne et al, 1999; Teng et al, 2005; Torres et al, 2010). No entanto, salientamos que no nosso estudo, a depressão não se encontre entre os dois mais prevalentes, contrariando a literatura. Também em conformidade com a revisão literária efectuada, a ansiedade regista índices superiores à depressão na amostra de mulheres com cancro da mama estudada (Burgesset al., 2005; Derogatis et al., 1983; Fernandes, 2009; Gallagher et al, 2001; Graner et al, 2008; Lueboonthavatchay, 2007; Patrão \& Leal, 2004; Tapadinhas, 2004; Torres et al., 2010).

Corroborando os resultados de outros trabalhos, a ansiedade é a resposta emocional mais manifestada pelas doentes com cancro da mama avaliadas quanto à sintomatologia psicopatológica. Como indicam muitos autores, é um quadro sintomático transversal a todas as fases do curso da doença (Carvalho, 2008; Fernandes, 2009; Okamuna et al, 2005; Pereira, 2008), face aos sentimentos de medo, incerteza, dúvida, relacionados com o diagnóstico, prognóstico, tratamentos, consequências dos tratamentos, exames, remissão, sobrevivência, recidiva, fase terminal. Ainda que possam ter atingidos picos de ansiedade elevada em algumas fases específicas, diagnóstico e pré-cirurgia (Hall et al., 1999). No entanto, à semelhança do verificado no nosso estudo, nem sempre tenha de ser necessariamente patológica (Stark \& House, 2000). Não obstante o screening de ansiedade clínica reveste-se de grande importância na prestação de cuidados oncológicos às doentes com cancro. Uma vez que esta interfere com a compreensão da informação recebida acerca da doença e tratamentos, compromete a adesão aos tratamentos, interfere com ação de alguns medicamentos, para além do sofrimento provocado e da afeção da qualidade de vida (Carvalho, 2008). 
As doentes da nossa amostra revelaram níveis elevados do sintoma obsessãocompulsão, ocupando o segundo lugar dos sintomas mais prevalentes. Trata-se de um quadro sintomatológico não referido na literatura como associado ao padrão de sintomatologia psicopatológica frequente nos doentes oncológicos em geral. Apenas Tavares (1999) descreve a perturbação obsessiva-compulsiva, como uma das perturbações de personalidade passível de ser encontrada nos doentes com cancro. Nenhuma referência bibliográfica foi por nós encontrada relativamente ao sintoma em doentes com cancro da mama. Denotam-se igualmente poucas referenciadas na literatura relativamente a quadros de obsessão-compulsão em mulheres com cancro da mama. Forner et al. (1986) já havia encontrado o quadro sintomático em doentes com cancro da mama. Patrão e Leal (2004) encontraram traços de organização em doentes com neoplasia da mama.

Por conseguinte, pensamos que a presença tão sublinhada do quadro sintomático obsessão-compulsão nas mulheres com cancro da mama observadas, poderá ser explicada de duas formas. Por um lado, sendo a obsessão-compulsão uma perturbação da ansiedade (DSM-IV e CID-10), e atendendo ao facto da ansiedade ser o sintoma mais prevalente nas doentes estudadas, prevemos que poderá estar a ela relacionado. Traduzindo-se numa tentativa, possivelmente fracassada, de lidar com a ansiedade, minimizando-a. Face a eventuais receios, medos e incertezas recorrentes e persistentes relacionados coma doença, tratamentos e sobrevivência. São frequentemente reconhecidos na interação com alguns doentes oncológicos e na experiência clínica com mulheres com cancro da mama, sentimentos de preocupação ansiosa relacionados com o seu estado de saúde e dos familiares. A representação traumática da experiência enquanto acontecimento de vida é suscetível de despoletar nas doentes da mama cognições persistentes e recorrentes de estar novamente doente, ou alguém na sua 
família estar doente, ou de agravamento do estado de doença. E como forma de tranquilização, as doentes passaram a adotar comportamentos de ritualização e verificação relacionados com a monitorização do seu estado de saúde ou dos seus, através da realização periódica de auto-exames, deslocações frequentes aos serviços de saúde ou procura de informação em livros e na internet, entre outras estratégias. $\mathrm{O}$ testemunho de uma doente enquanto respondia ao protocolo de investigação é ilustrativo do que acabámos de referir: "Sentia que tinha umas palpitações no corpo, então pensava que já tinha ali outro cancro, então aconselharam-me um psicólogo” (40 anos, tumorectomizada).

Por outro lado, estes resultados poderão abrir a possibilidade à colocação da hipótese do sintoma obsessão-compulsão ser passível de consistir uma característica da personalidade prevalente em mulheres com cancro da mama, prévia ao aparecimento da doença ou, como referimos acima, decorrente da mesma.

Foi identificada uma propensão para a personalidade com traços de organização, verificação, arrumação, ritualização e limpeza relacionada essencialmente com as tarefas domésticas em algumas doentes, enquanto respondiam aos questionários de avaliação. Após o aparecimento da doença a concretização dessas preocupações ficou comprometida, ainda que se tenham mantido de forma recorrente no pensamento. Em virtude das limitações na funcionalidade física, que nomeadamente, a mastectomia radical deixou nas mulheres com cancro da mama entrevistadas. "Quando me enervo limpo tudo, á noite não durmo com as dores. Os vizinhos falam se a gente tem as coisas sujas. Depois à noite não durmo com dores" (43 anos, mastectomia radical).

Estas limitações parecem ter implicações, segundo as narrativas das doentes, no sentimento de identidade pessoal, profissional, familiar e social, repercutindo-se na 
auto-estima. Também esta diminuição da funcionalidade se poderá refletir nos valores mais expressivos do sofrimento socio-relacional. Consideramos que a investigação do sintoma obsessão-compulsão em mulheres com cancro da mama deverá merecer atenção dos pesquisadores em estudos posteriores.

A somatização constitui o terceiro quadro sintomático mais prevalente nas mulheres com cancro da mama investigadas. Indicando, como de resto é referido na literatura, que as queixas físicas são frequentes ao longo do processo, podendo resultar da sintomatologia física decorrente da doença, designadamente, dos tratamentos, ou ser melhor explicada pela associação a sintomatologia psicológica, nomeadamente, ansiedade e depressão, enquanto respostas emocionais ao processo de doença (Purushothan et al, 2005; Ramos, 2007). Recorrentemente, no contexto clínico da prestação de cuidados oncológicos, não é efetuado correto diagnóstico diferencial dos sintomas de somatização. Quando associada a sintomatologia psicológica, a somatização pode ser ignorada pelos profissionais de saúde, ou tratada com antidepressivos e ansiolíticos. Quando relacionada a sintomas secundários aos tratamentos, é atendida na perspetiva da dor. No entanto, em psicologia sabemos que na génese da somatização estão sempre variáveis psicológicas. Defendemos por isso, que o sintoma somatização é de grande relevância no contexto da prestação dos cuidados de saúde às doentes com cancro da mama, pois para além se provocar sofrimento, compromete a adesão terapêutica, os tratamentos e o prognóstico, para além de representar custos em saúde, pois estas doentes, são muitas vezes sub-medicadas.

Contrariamente ao que prevíamos na $\mathrm{H} 5$, as variáveis sociodemográficas não influem na sintomatologia psicopatológica. No entanto, a influência deste grupo de variáveis é confirmada noutros trabalhos, nomeadamente, em relação aos quadros de maior prevalência entre os doentes com cancro. Mulheres mais novas apresentam menos 
depressão (Harris \& Maguire, 1995). O estado civil também parece exercer influência na morbilidade depressiva (Harris et al., 1995). No nosso estudo, apenas a escolaridade tem efeitos significativos no sintoma somatização. São as doentes que não frequentam a escola ou que cumpriram o $1^{\circ}$ ciclo do ensino básico que registam valores mais elevados do sintoma comparativamente com as que detém habilitações académicas superiores. Resultado similar foi encontrado por Tapadinhas (2004) numa amostra congénere mas relativamente à depressão. As doentes mais escolarizadas apresentavam menor tendência para a depressão.

Uma vez mais, à semelhança do que se verificou relativamente ao sofrimento, a escolaridade poderá conferir às doentes o desenvolvimento de melhores competências para lidarem com a doença, designadamente, na procura de informação e apoio instrumental sobre a doença, melhor capacidade de comunicação com os profissionais de saúde acerca do quadro clínico da mesma, envolvendo-se mais ativamente nos procedimentos terapêuticos, evidenciam menos sintomas psicopatológicos, conseguindo melhor ajustamento à experiência de doença, e isso reflete-se na menor tendência de manifestação do sintoma.

Por outro lado, atendendo a que as doentes com habilitações superiores, são em média mais jovens. A maior resistência física associada à idade, poderá igualmente capacitar estas doentes para melhor superação dos efeitos colaterais dos tratamentos, nomeadamente, da quimioterapia, comparativamente com as doentes de mais idade.

Assim, ao que parece, a variável escolaridade ganha pertinência empírica e clínica no trabalho com doentes com cancro da mama. Estes resultados vêm conscientizar para o facto das doentes com baixas habilitações merecerem maior 
atenção da parte dos profissionais de saúde, uma vez que constituem grupos de risco em matéria de morbilidade psicológica decorrente do aparecimento da doença.

Não foram reportados efeitos das variáveis clínicas na variação da sintomatologia psicopatológica nas doentes com cancro da mama observadas, como previsto em H6. Todavia, referências na literatura associam maiores índices de depressão aos efeitos dos tratamentos (quimioterapia e mastectomia) (Maison \& Miller, 2003; Mitchell et al., 2012), e queixas de dor (Mitchell et al., 2012; Pimenta et al, 2000). Em doentes com cancro da mama concretamente, a morbilidade psicopatológica apresenta variações em função da fase do curso da doença. A fase de diagnóstico é um período crítico, favorável à manifestação de ansiedade, principalmente, mas também depressão (Burges set al, 2005; Fernandes, 2009; Graner et al., 2008; Moreira et al,, 2008). A fase de tratamentos (quimioterapia e cirurgia), é igualmente propensa a maior ansiedade (Fernandes, 2009; Green et al., 2000). O tipo de cirurgia exerce influência preponderante na relevância da sintomatologia psicopatológica. Doentes mastectomizadas apresentam níveis superiores de depressão (Granz et al., 1992; Maraste et al.,1992; Montgomery \& Bovbjerg, 2004). Porém, tal não foi verificado pelo nosso estudo.

O terceiro objetivo do presente trabalho consistiu em observar se as variáveis empíricas em estudo, a experiência subjetiva de sofrimento na doença e a sintomatologia psicopatológica se relacionavam nas doentes com cancro da mama da amostra estudada. Como esperado, e confirmando H8, as duas variáveis correlacionamse significativamente em todas as dimensões correspondentes a cada uma. $\mathrm{O}$ sofrimento físico correlaciona-se de forma mais expressiva com a somatização, seguindo-se a obsessão-compulsão e o IGS. No sofrimento psicológico as correlações mais fortes são com a depressão, ansiedade e com os três índices de severidade. O sofrimento sócio- 
relacional correlaciona-se de forma mais sublinhada com o psicoticismo, obsessãocompulsão, depressão e com os três índices. O sofrimento existencial fortemente com o IGS, obsessão-compulsão, depressão, sensibilidade inter-pessoal e o ISP e TSP. Por fim, as experiências positivas de sofrimento apresentam correlações, no sentido inverso, mais expressivas com a depressão, somatização, hostilidade e com os três índices, embora com estes a correlação seja mais fraca.

Atendendo a que o sofrimento psicológico, socio-relacional e existencial apresentam correlações expressivas com os três índices de severidade psicopatológica, à exceção do sofrimento existencial onde as correlaçãos são mais modestas. Esta relação poderá ser indicadora da possível contribuição das três dimensões, quando associadas a níveis elevados de sofrimento e caso este não seja atendido, para a desenvolvimento de sintomatologia psicológica severa.

Não obstante, como era expectável em $\mathrm{H}$, essa previsibilidade não ficou estatisticamente comprovada. Porém, os resultados apontam para a possibilidade do sofrimento existencial ser o melhor preditor do TSP, e o sofrimento psicológico do IGS. Assim, com base nos resultados verificados, defendemos que a investigação da relação e dos efeitos entre as duas variáveis dá mostras de reunir pertinência e utilidade científica e clínica, na avaliação, compreensão e tratamento da morbilidade existencial e psicopatológica das doentes com cancro da mama.

Por último, procurámos traçar um perfil de morbilidade psicológica das doentes com cancro da mama estudadas, tendo em conta os resultados verificados (H8). Para tal, como explicamos anteriormente, face às variáveis empíricas em estudo, foram constituídos três grupos de severidade, baixa, moderada e elevada. Pretendíamos, desta forma, encontrar um padrão de sofrimento e um padrão psicopatológico das mulheres 
com cancro da mama da amostra. No sentido de encontrar correspondência entre as variáveis psicológicas avaliadas e o cancro da mama, à semelhança do que foi realizado noutras Trabalhos, como os que identificaram o padrão de personalidade tipo C (Fox, Temoshok \& Brehen, 1988; Kreiner \& Temoshok, 1984). Ficou assim demonstrado que a severidade do sofrimento das doentes com cancro da mama avaliadas é mais elevada no sofrimento socio-relacional, no sofrimento psicológico e existencial, sendo que o primeiro é superior aos outros todos. Conseguimos assim obter um padrão de sofrimento associado ao cancro da mama, compreensível pelas características da doença e tratamentos e do respetivo impacto a nível psicossocial e existencial. A neoplasia da mama pelo órgão envolvido tão associado à condição sexual feminina (Borbeau, 2009; Michelena, 2010; Milsztjsn, 2010; Pereira, 2008; Santos, 1999), comparativamente com outros tipos cancro na mulher, tem um impacto acrescido na corporalidade, feminilidade, sexualidade, repercutindo-se nos relacionamentos interpessoais, íntimos e sexuais (Barros, 2008; Dias, Costa, Jiménez \& Pais-Ribeiro, 2019; Manuel, Xavier \& Costa, 2001; Faria \& Xarepe, 2000; Pereira, 2008; Silva, 2008). A cirurgia, nomeadamente a mastectomia radical inflige, a curto e médio prazo ou irreversivelmente, incapacidade funcional, limitações nas atividades da vida diária, ocupacionais e laborais, e isso por sua vez, acarreta alterações cognitivas e emocionais, associadas ao questionamento existencial da vida e da condição de mulher identidade pessoal, sentido de controlo, projetos futuros (Aureliano, 2007). Assim se explica o padrão de sofrimento socio-relacional, psicológico e existencial encontrado nas doentes com cancro da mama da amostra em estudo. Pois como refere Cassell (1982) não são os factos que originam o sofrimento, mas a representação atribuída aos factos. Por isso são observados outros padrões de sofrimento noutros doentes. Um trabalho realizado por Rodrigues, Cunha e Pereira (2010), um dos poucos conhecidos de avaliação da 
experiência subjetiva de sofrimento na doença em doentes com cancro da mama, também encontrou níveis superiores de sofrimento psicológico e socio-relacional na amostra estudada, sendo que, ambos eram superiores nas doentes mulheres mastectomizadas comparativamente com as tumorectomizadas. No entanto, aqui o sofrimento socio-relacional foi inferior ao psicológico. Em doentes internados nos cuidados intensivos, os níveis de sofrimentos encontrados por Bento (2000) vão encontro do padrão por nós encontrado (sofrimento socio-relacional, psicológico e existencial). Já em doentes com dor crónica, o sofrimento físico prevalece sobre todos os outros (Araújo-Soares \& McIntyre, 2000). Numa amostra com doentes com esclerose múltipla, o sofrimento socio-relacional aparece novamente como dominante (Soares, 2000).

Sublinham-se ainda duas notas, o perfil do sofrimento observado em função dos níveis severidade difere ligeiramente dos resultados fornecidos pela análise das médias e desvio padrão da avaliação do sofrimento efetuada, no que ao sofrimento existencial diz respeito. Nessa análise o sofrimento existencial obteve uma das médias inferiores. Os restantes, socio-relacional, psicológico e experiências positivas registaram médias enquadradas dentro do perfil observado em função da severidade do sofrimento. A outra nota diz respeito às experiências positivas de sofrimento na doença. Quer na comparação entre médias, quer na comparação entre níveis de severidade, firmam a sua presença na experiência de doença das doentes com cancro da mama estudadas. Indicando que apesar do sofrimento experimentado na trajetória de doença, dada a sua natureza positiva, as doentes continuam a desenvolver expectativas otimistas face à vida e à sua saúde. No perfil de sofrimento ao aparecerem reportadas ao nível de baixa severidade, as experiências positivas poderão exercer uma função atenuante/moderadora da experiência de sofrimento na doença, no sentido em que ajudam as doentes a 
reequacionarem as perdas sofridas na doença e a perspetivar possíveis transformações positivas decorrentes da experiência de doença (McIntyre, 1995ª; 1995 ; 2004; Urcuyo at al., 2005). O sofrimento existencial e as experiências positivas de sofrimento na doença assumem neste trabalho relevância teórica, empírica e clínica no âmbito do estudo e prestação de cuidados oncológicos às doentes com cancro da mama.

Revela-se assim pertinente e urgente avaliar a experiência subjetiva de sofrimento na doença neste grupo de doentes, atendendo ao padrão de sofrimento encontrado, pois para além de afetar a qualidade de vida, é suscetível de evoluir para sintomatologia psicopatológica e comprometer a adesão terapêutica e o diagnóstico. Pode ainda deixar marcas intrapsíquicas duradoras já na fase da sobrevivência. Por isso, intervenções psicológicas e terapêuticas breves centradas no sofrimento na doença são aconselhadas a doentes com cancro da mama, onde as reações emocionais face à doença causadoras de sofrimento possam ser ventiladas (aguiar \& Fonte, 2007; Favoreto 6 Cabral, 2009; Sasdelli \& Miranda, 2001). O counselling segundo alguns autores (Bayés, 1998; Gameiro, 1999) constitui uma ferramenta em eficaz na minimização do sofrimento dos doentes. Ajudando na promoção do crescimento na doença, através da resignificação acontecimento doença e da própria vida (Gameiro, 1999; McIntyre, 1995 ; McIntyre, 2004; Moura, 2008). No entanto, como referem Bayés (2003 ${ }^{\text {b }}$ e McIntyre (1995 $)$ atender e aliviar o sofrimento deverá ser uma preocupação ética de todos os profissionais de saúde.

Analisando agora o padrão de sintomatologia psicopatológica verificado nas doentes com cancro da mama estudadas. Este caracteriza-se por apresentar maior severidade nas dimensões sintomatológicas obsessão-compulsão, depressão, ansiedade e sensibilidade interpessoal Verificando-se uma troca de posições na avaliação da severidade dos quadros sintomatológicos comparativamente com a análise das médias. 
Em ambas a análise estatísticas, um quarto quadro sintomatológico difere. A somatização regista a terceira média mais alta entre a população com cancro da mama estudada. No entanto, esta não se encontra entre as quatro dimensões de sintomas psicopatológicos de severidade elevada. Em sua substituição, aparece a sensibilidade interpessoal como o quarto sintoma de maior severidade nas doentes avaliadas.

A depressão, o quarto sintoma com média mais elevada nas doentes estudadas, correspondendo ao segundo sintoma associado a um nível de severidade elevado, seguindo-se a ansiedade em terceiro lugar. Desta feita, indo ao encontro dos estudos de avaliação dos distúrbios psicológicos em doentes com cancro da mama, a amostra estudada, apesar de apresentar sintomatologia de intensidade ligeira a moderada, quando os quadros assumem relevância clínica, a depressão e ansiedade correspondem aos distúrbios mais documentados pela literatura na população oncológica em geral, e nas doentes com cancro da mama, em particular (Akechi, et al, 2004; Burgess, et al., 2005; Derogatis, et al., 1983; Graner, et al., 2008; Luenoonthvatchay, 2007; Mitchell, et al., 2011; Patrão \& Leal, 2004; Torres, et al., 2020). No entanto, em termos de severidade elevada, a depressão no nosso estudo apresenta níveis superiores à ansiedade. Tendência inversa há verificada na maioria dos estudos com doentes com neoplasia mamária (Fernandes, 2009; Gallagher, et al.2002; Hall, et al., 1999; Manaste, et al., 1992; Montazer, et al., 2001; Okanura, et al., 2005; Tapadinhas, 2004; Torres, et al., 2010).

Tendo em conta a representatividade da depressão na severidade da morbilidade verificada na amostra estudada, os nossos resultados, seguindo a descrições dos estudos consultados, parecem comprovar que o quadro depressivo constitui uma resposta emocional frequente em mulheres com cancro da mama, face às alterações e perdas sofridas com a experiência de doença (Raison \& Miller, 2003). Perdas de ordem física, psicológica, social, e em alguns casos, até a nível existencial e espiritual. Narrativas das 
doentes recolhidas durante a aplicação do protocolo de avaliação parecem ser demonstrativas das principais perdas sofridas pelas doentes com cancro da mama estudadas, na sua representação subjetiva: (1) perdas físicas/funcionalidade - "O braço esquerdo não tem força nenhuma". (40 anos, tumorectomizada); "Falta de força no corpo por motivos de doença”. (37 anos, mastectomia);(2) perdas na imagem corporal e sexualidade - "A pior coisa foi a queda do cabelo, isso é que foi o desabar da situação, não por mim, mas pelos netos. "(61 anos, mastectomizada); - "a queda do cabelo chocou-me, foi das coisas que mais me custou, e que mais me está a chocar ...”. (55 anos, não fez cirurgia); "Eu tinha uma trança ...custa". Isso é que dói ... eu tinha o cabelo muito forte. Um dia o meu filho disse que o cabelo voltava a crescer e isso fezme chorar, ele agarrou-se a mim chorar, coitadinho. Já viu uma mulher sem cabelo e sem peito ... o que é que é da mulher?!” (57 anos, mastectomia radical); "Quando o meu marido está ao pé de mim, tenho receio de mostrar o meu corpo, sei que tenho o meu corpo desfigurado!" (42 anos, mastectomizada); “Antes do aparecimento da doença a vida sexual era normal, agora é uma obrigação. Anteriormente tinha prazer, agora não" (40 anos, tumorectomizada); "Acho que o cancro afetou a vida sexual. Não tenho vontade de ter relações, não sei se é da medicação que estou a tomar, às vezes tenho dores, estou mal disposta. Antes da doença tinha uma vida sexual satisfatória. (32 anos, tumorectomizada); (3) perdas de papeis sociais - "Era feliz, trabalhava no campo, gostava de ir ganhar dinheiro”. (43 anos, mastectomia radical); “Sentir a falta do trabalho. Dos amigos com quem trabalho, há um ambiente bom”. (55 anos, a aguardar cirurgia); (4) alterações na dimensão existencial e espiritual - "Quando tive esta doença pensava para mim mesma que estou a ser castigada por alguma coisa que fiz" (40 anos, tumorectomizada); - "Parece que desde que adoeci a minha fé foi embora" (68 anos, tumorectomizada). 
O facto de, segundo alguns estudos, a depressão nas doentes com cancro da mama ocupar $3^{\circ}$ lugar nas taxas de maior prevalência de depressão em todos os tipos de cancro (Golden-Kneutz \& Anderson, 2004), deverá constituir uma preocupação, quer para investigadores, no sentido de comprovar, a sua efetividade, quer para os profissionais de saúde. Pois como já foi referido, a depressão enquanto resposta emocional à doença afeta a qualidade, interfere com a adesão aos tratamentos, compromete o ajustamento à doença, o prognóstico e a sobrevivência (Teng et al., 2005. A juntar a tudo isto, aumenta o risco de suicídio nos doentes oncológicos (Raison \& Miller, 2003; Tavares, 1999; Teng et al., 2005, Tjemsland et al., 1997; Trancos et al., 2010). Realidade comprovada em contexto clínico em número de casos não negligenciável. Foi constatada ideação suicida em algumas doentes estudadas, no âmbito do trabalho de campo realizado aquando da aplicação dos instrumentos de avaliação. Registamos aqui dois exemplos: "Já me deu ideia de me matar, desde que estou doente, pois sinto-me muito sozinha, não posso trabalhar”. (43 anos, mastectomia radical); “Custa muito... Se tivesse um marido mau, já me tinha matado!"(43 anos, mastectomia).Como tal, a avaliação, diagnóstico e tratamento da perturbação depressiva em doentes com cancro da mama parece-nos condição impreterível (Fann et al., 2008).

Se no que respeita à depressão e ansiedade, o padrão de sintomatologia psicopatológica encontrado na amostra do nosso estudo corrobora os resultados de outros trabalhos com amostras equivalentes. Fazem parte do padrão psicopatológico por nós encontrados dois quadros sintomatológicos cujas referências são escassas na literatura referente a doentes com cancro da mama, a obsessão-compulsão, sintoma associado a maior severidade, e a sensibilidade interpessoal, o quarto associado a severidade mais elevada. 
A obsessão-compulsão foi o sintoma associado ao nível mais elevado de severidade no padrão de sintomalogia psicopatológica observado nas doentes com cancro da mama avaliadas. Foi o segundo sintoma a registar a média mais elevada nas doentes analisadas. Este quadro sintomático encontra-se pouco referenciado na literatura nas mulheres com cancro da mama. Não obstante, alguns autores reportam a o traço de personalidade obsessão-compulsão em estudos realizados com amostras de doentes com cancro da mama. Forner et al. (1986) num estudo sobre personalidade prévia e cancro da mama encontraram na amostra avaliada traços de personalidade relacionados com a auto-exigência de perfeição e a auto-responsabilidade. Patrão e Leal (2004), utilizando o modelo de personalidade big five, identificaram traços de organização nas doentes com cancro da mama estudadas. Este traço, conjuntamente com outros encontrados nas mulheres avaliadas, tais como: ser calma, resistente, não-emotiva, reservada, pragmática, prestável, disponível, simpática, trabalhadora e confiável, permitiu às autoras traçar um perfil das doentes, marcado pela baixa expressividade emocional, característica associada à personalidade Tipo C. Tavares (1999) refere que a perturbação obsessiva-compulsiva é uma das perturbações da personalidade que pode ser encontrada em mulheres com cancro da mama.

Os resultados obtidos não nos permitem fazer esse tipo de inferência. Não obstante, poderão abrir novos caminhos para a necessidade de investigar futuramente a prevalência do sintoma/transtorno obsessão-compulsão em doentes com cancro da mama, em duas direções principais: (1) existência de personalidade prévia obsessivocompulsiva em mulheres com cancro da mama, (2) prevalência do distúrbio obsessivocompulsivo decorrente do aparecimento do cancro da mama, no sentido de pesquisar se se trata do terceiro quadro clínico do grupo das perturbações da ansiedade (ansiedade e 
stresse) mais prevalente, juntamente com as perturbações do humor (depressão), mais prevalentes no cancro da mama, e nos doentes oncológicos em geral.

A sensibilidade interpessoal, raramente é avaliada isoladamente em psicooncologia. São características deste quadro sintomático pensamentos e sentimentos associados à auto-depreciação, inferioridade perante os outros, hesitação e desconforto e timidez perante situações e interações sociais. Traços associados a este quadro foram encontrados noutros estudos. Forner, et al., 1986, identificaram o traço de dependência social em doentes com cancro da mama. Neme e Bredariolli (2010) reportaram igualmente traços de personalidade insegura e dependente, caracterizados por necessidade de aceitação e apoio de terceiros, condizentes com o quadro de sensibilidade interpessoal. Também no perfil de personalidade encontrado em mulheres com cancro da mama por Patrão e Leal (2004), alguns traços relacionam-se com a sensibilidade interpessoal.

À semelhança do que acontece com sintoma obsessão-compulsão, os resultados obtidos não permitem afirmar com clareza se a sensibilidade interpessoal reportada a índices de severidade elevada no padrão de sintomatologia psicopatológica observado, corresponde a personalidade prévia ao aparecimento da doença, ou se trata de sintomatologia psicológica decorrente do cancro da mama. Considerando a tipologia da doença oncológica da mama e o impacto dos tratamentos, nomeadamente da quimioterapia e mastectomia, na imagem corporal e corporalidade, com reflexo na autoestima, sentimento de identidade e dignidade, comprometendo a relação consigo mesma, consequentemente, os relacionamentos interpessoais resultam igualmente afetados. Deixando as mulheres com cancro da mama mais vulneráveis a quaisquer reações de terceiros, avaliadas subjetivamente como mais depreciativas, podendo o evitamento ser uma conduta habitual a adotar. Este tipo de experiência e resposta 
emocional face aos relacionamentos interpessoais e contactos sociais foi testemunhado por diversas doentes com cancro da mama, aquando do preenchimento do protocolo de avaliação, deixamos aqui alguns exemplos: "Se as pessoas me dessem valor talvez não estivesse assim ...” (70 anos, mastectomizada); “Eu dou-me valor, mas para as pessoas acho que agora já não tenho o mesmo valor" (40 anos, tumorectomia); "Quem era, e o que sou ..."(68 anos, tumorectomia); "Uma vez fui abordada por uma colega na rua, disse-me - estás mesmo com cara de doente, nem pareces tu, então com essa peruca... fiquei tão triste (...). Desde então, evito sair com receio de ouvir a mesma coisa”. (55 anos, não fez cirurgia).

Pettingale, Watson e Greer (1985) referem que estas doentes podem revelar-se mais perturbadas emocionalmente do que aparentam. Como tal, estudar a sintomatologia psicopatológica revela-se pertinente sob os pontos de vista empírico e clínico, na medida que a presença de quadros de ansiedade, depressão e stresse comprometem o ajustamento ao processo de doença (Carvalho, 2008; Mitichell et al. 2012; Teng et al., 2005), adesão aos tratamentos (Carvalho, 2008; Holland, 1998) e sobrevivência (Deroagatis et al., 1978; Hilakivi et al., 1994; Holland \& Mastrovito, 1980).

Tempo agora para refletir sobre as limitações do presente estudo, que passamos em seguida a enumerar e descrever. A primeira limitação, consiste em nossa opinião, no tamanho da amostra $(n=104)$. Por nós considerada pouco representativa do universo que pretendíamos estudar, suscetível de constituir alguns constrangimentos à generalização dos resultados obtidos. Não obstante, sublinhamos, que a amostra foi recolhida em contexto hospitalar, encontrando-se todas as doentes, apesar de constarem de diferentes fases do curso da doença, a realizar tratamentos. Este argumento, defende-nos, de certa forma, da crítica da representatividade das amostra, pois muitos estudos com 
amostragens maiores utilizam doentes sobreviventes há mais de cinco anos, que não se encontram a realizar qualquer tipo de tratamento, recolhidas da população em geral, na sua maioria, em instituições de voluntariado ligado às doenças oncológicas. A nossa, apesar de pequena, recordamos, representa o universo das doentes com cancro da mama em tratamento e seguimento da doença em contexto hospitalar.

Outra limitação por nós apontada, diz respeito ao contexto geográfico no qual a amostra foi recolhida, o interior norte do país, com características ambientais, económicas e socioculturais, onde a ruralidade e distância dos grandes centros urbanos são predominantes. Conferindo à nossa amostra um perfil sociodemográfico distinto de amostras recolhidas nos centros urbanos do litoral, comprometendo desta feita a generalização dos nossos resultados face a outros utilizando amostras com características diferentes.

A concluir o capítulo apontamos algumas considerações para trabalhos futuros no âmbito da experiência subjetiva de sofrimento na doença e sintomatologia psicológica em doentes oncológicas da mama. Defendemos, em primeiro lugar, que a experiência subjetiva de sofrimento na doença enquanto reflexão fenomenológica e existencial, numa perspetiva "despatologizada" como defendem Gameiro (1999) e McIntyre (2002) deverá continuar a ser estudada em doentes com cancro da mama. Bem como, a sintomatologia psicopatológica e respetiva relação entre as duas variáveis.

Em segundo lugar, acrescentamos a pertinência científica e clínica do estudo da relação do sofrimento e sintomatologia psicopatológica com outras variáveis, nomeadamente de ajustamento ao processo de doença.

Em terceiro lugar, propomos a retoma do estudo da personalidade enquanto variável determinante no processo de ajustamento ao cancro da mama, enquanto 
variável moderadora (Holland, 2002), investigando a relação entre experiência de sofrimento e sintomatologia psicopatológica, e possíveis efeitos na sobreviva das doentes (Rojas-May, 2007), por forma a testar se a personalidade tem um papel psicoprofilático (Botelho, 2006) no contexto da doença oncológica da mama.

Em quarto e último lugar, no seguimento da recomendação anterior, defendemos que também o estudo da personalidade Tipo C associada às estratégias de coping deverá ser retomado, por forma a conhecer os efeitos reais no ajustamento à doença, adesão aos tratamentos, sobrevivência e possível relação com a recidiva da doença (Classen, et al., 1996; Iwamitsu, et al., 2003; Reynolds, et al., 2000; Watson, et al, 1991; Watson, et al, 1999; Watson, et al., 2005). Desta forma, doentes de personalidade difícil ou com perturbação da personalidade podem ser diagnosticados e submetidos a intervenção psicoterapêutica com o objetivo de melhorarem o seu ajustamento à doença, participando de forma ativa na luta contra a mesma, aumentando assim a probabilidade de sobrevivência. Tratar-se-ia de um contributo notável para o regresso do estudo da psicologia personalidade ao contexto de saúde/doença como defende (Andéu, 2001). Afirmando-se assim, ainda de forma mais vincada, a psicologia no contexto da oncologia, precisamente na área do conhecimento que conduziu ao nascimento da psicooncologia, a das variáveis de personalidade identificadas nos doentes com cancro, comprometedoras do processo terapêutico (Ibáñez, et al., 2001;Justo, 2001; Andéu, 2001).

Mesmo a terminar, acreditamos que o estudo fidedigno das relações entre as variáveis atrás mencionadas só é possível através de desenhos experimentais de natureza prospetiva e longitudinal, como defende Temoshok (1987). Por conseguinte, defendemos a realização de estudos desta natureza no sentido de perceber mais aprofundadamente a influência das variáveis de personalidade na proteção da saúde, 
desenvolvimento de doenças, e ajustamento ao processo de doença oncológica, nomeadamente, o cancro da mama. 


\section{CONCLUSIONES}

«Lo que es más profesional no siempre es lo que más cura» (Rachel Remen, 1998, Histórias que curam, pág. 209)

El propósito de este trabajo ha sido contribuir a una reflexión sobre la problemática del sufrimiento en la enfermedad en mujeres con cáncer de mama, en una perspetiva existencial y normativa asociada al proceso de enfermedad, y para la distinción del sufrimiento existencial del sufrimiento psicopatológico; destacando la necesidad de atender al sufrimiento, como experiencia psicoemocional y existencial normal en el proceso de enfermedad y su distinción de la sintomatología psicopatológica.

Asimismo, procuramos observar en qué medida las variables, a pesar de ser diferentes, se relacionaban, en cuanto a la posibilidad de que el sufrimiento haga evolucionar o agravarse la sintomatología psicopatológica. A la vista de los resultados obtenidos, comprobamos que el sufrimiento acompaña a la experiencia subjetiva de la enfermedad en mujeres con cáncer de mama, donde la sintomatología psicológica puede que no siempre estar presente y, cuando lo está, no alcanzar relevancia clínica.

En cuanto a la caracterización del sufrimiento experimentado por las pacientes con cáncer de mama estudiadas, verificamos que la dimensión sociorrelacional alcanza niveles superiores de sufrimiento en comparación con todas las demás, aunque en un registro de intensidad de ligero a moderado (H1). Las experiencias positivas de sufrimiento en la enfermedad son las segundas que registran índices más elevados, lo 
que indica que las mujeres con cáncer de mama evaluadas encuentran un sentido positivo en la experiencia de sufrimiento en la enfermedad. En el estudio de la variabilidad del sufrimiento en función de las variables sociodemográficas (H2), observamos que solamente la escolaridad influye en la experiencia en todas las dimensiones, salvo en el sufrimiento sociorrelacional, que reveló ser transversal en todas las variables analizadas: edad, estado civil y escolaridad. Esto parece indicar que poseer formación académica superior dota a las pacientes con cáncer de mama de estrategias de afrontamiento de la enfermedad más eficaces, lo que les hace experimentar menos sufrimiento. Respecto a las variables clínicas, se demostró que la disminución de la funcionalidad está asociada al sufrimiento físico (H3). Asimismo, se constató que el tipo de cirugía parece influir en el desarrollo de experiencias positivas frente a la enfermedad, en el grupo de pacientes que no se sometieron a cirugía.

En cuanto a la sintomatología psicopatológica, a pesar de que no se comprueba significancia clínica, observamos que la ansiedad, los trastornos obsesivos-compulsivos, la somatización y la depresión, por este orden, son los síntomas que presentan índices más elevados (H4). En la evaluación de la variabilidad de los cuadros sintomáticos en función de las variables sociodemográficas (H5), una vez más los resultados apuntan a una influencia de la escolaridad en la sintomatología evaluada. Respecto a las variables clínicas (H6), parecen no interferir en la sintomatología observada en la muestra estudiada.

Por otra parte, se observó una asociación estadísticamente significativa entre todas las dimensiones del sufrimiento y todas las dimensiones de la sintomatología psicopatológica, inclusivamente entre los tres índices de severidad. Así pues, se percibió la pertinencia del estudio de dos variables en conjunto. Índices elevados de sufrimiento en todas las dimensiones corresponden a índices elevados de todas las dimensiones 
psicopatológicas, con excepción de las experiencias positivas de sufrimiento en la enfermedad, cuyos valores más elevados corresponden a menores índices de depresión, somatización, hostilidad y a una menor severidad de todos los síntomas.

No obstante, los resultados no permiten esclarecer si la experiencia de sufrimiento en la enfermedad contribuye a la evolución o al agravamiento de la sintomatología psicológica, o a ambas situaciones (H7). Tal como se pretendía, el diseño de la investigación también permitió trazar un perfil de morbilidad psicológica de las pacientes con cáncer de mama que constituyeron la muestra (H8). Se encontraron dos patrones de morbilidad asociados a tres niveles de severidad (baja, media y elevada), una para cada variable empírica. El patrón de sufrimiento de las pacientes estudiadas en términos de severidad elevada se caracteriza por: sufrimiento sociorrelacional, sufrimiento psicológico, sufrimiento existencial y experiencias positivas. El patrón de sintomatología psicopatológica respecto al nivel de severidad se caracteriza por: trastorno obsesivo-compulsivo, depresión, ansiedad y sensibilidad interpersonal.

A modo de conclusión, consideramos que los resultados de este trabajo suponen importantes contribuciones a los ámbitos científico y clínico. Por un lado, quedó demostrada la relevancia del estudio del sufrimiento en la experiencia subjetiva del paciente, en una perspetiva «despatologizada», en la que el sufrimiento experiencial se distingue del sufrimiento psicopatológico. Por otro lado, conseguimos trazar un perfil de morbilidad psicológica en términos de sufrimiento y sintomatología psicopatológica, que nos permite conocer mejor la salud mental derivada de la experiencia de enfermedad de las pacientes con cáncer de mama. A nuestro modo de ver, estas observaciones ofrecen indicaciones que no deben ser ignoradas en la prestación de 
cuidados sanitarios a las pacientes oncológicas de mama, tanto por los profesionales de la salud, en general, como por los psicólogos oncólogos, en particular.

En este sentido, el sufrimiento debe atenderse en contextos de enfermedad en una perspetiva global, «despatoligizada» y despsicologizada, sin que sea exclusividad de los profesionales de salud mental, pero sí una obligación de todos los profesionales de la salud durante la prestación de los cuidados, a fin de garantizar la calidad de vida del paciente durante el proceso de enfermedad. La sintomatología psicopatológica constituye un «desvío» en el proceso de adaptación al proceso de enfermedad, cuya evaluación, diagnóstico y tratamiento, estos sí, son exclusivos de los profesionales de salud mental. 


\section{REFERÊNCIAS}

Abdelmalek, A.A., \& Gérard, J.L. (1999). Ciências humanas e cuidados de saúde: manual para profissionais de saúde. Lisboa: Instituto Piaget.

Akechi, T., Okuyama, T., Sugawara, Y., Nakano, T., Shima, Y., \& Uchitomi, Y. (2004). Major depression, adjustment disorders, and post-traumatica stress disorder in terminally ill cancer patients: associated and predictive fatos. Clinical Oncology, 22(10), 1957-1965.

Almeida, J.M.P., \& Melo, J.S. (2002). Ética, espiritualidade em oncologia. In. M.R. Dias, \& E. Durá. Territórios da psicologia oncológica (pp. 129-143). Lisboa: Climepsi.

Amado, M.A. (2007). Acasos da minha vida. Braga: Oficinas de Artes Gráficas da APPCDM.

Amaral, A. \& Moreira, H. (2009). Qualidade de Vida e Ajustamento Psicossocial em Mulheres com Possibilidade de Diagnóstico e recentemente Diagnosticadas com Cancro da Mama. In. S. N. Jesus, I. Leal, \& M. Resende (Orgs.) Experiências e Intervenções em Psicologia da Saúde: Resumos e Textos. Faro: Universidade do Algarve, pp.475-485.

American Cancer Society (ACS) (2009), What Are the Key Statistics for Breast Cancer? $\begin{array}{lllllll}\text { Acedido a } & 08 & \text { de } & \text { Setembro de } & 2009 & \text { em }\end{array}$ http://www.cancer.org/docroot/CRI/content/CRI_2_4_1X_What_are_the_key_st atistics_for_breast_cancer_5.asp? sitearea

American Psychiatric Association (1996). DSM-IV: Manual de Diagnóstico e Estatística das Perturbações Mentais. (4 ${ }^{\mathrm{a}}$ ed.). Lisboa: Climepsi.

Amorim, L., \& Pereira, M.G. (2009). Morbilidade Psicológica, Otimismo, Satisfação com o Suporte Social e Exaustão Familiar em Doentes Oncológicos e Filhos Adultos de Doentes Oncológicos. In. S. N. Jesus, I. Leal, \& M. Resende (Orgs.) Experiências e Intervenções em Psicologia da Saúde: Resumos e Textos. Faro: Universidade do Algarve, p. 620.

Anandanajah, G., \& Hight, E. (2001). Sprituality and medical practice: using the hope questions as a practical tool for spirituality assessment. American Familiy Physician, 63(1), 81-88.

Andreu, Y. (2002). Personalidad tipo C: historia y validez del concepto. In. M.R. Dias \& E. Durá (coordenação). Territórios da psicologia oncológica (pp. 399-426). Lisboa: Climepsi.

Anjos, A. C. \& Zago, M. M. F. (2006). A experiência da terapêutica quimioterápica oncológica na visão do paciente. Revista Latino-americana de Enfermagem. 14 (1), 33-40. 
Aquino, V.V., \& Zago, M.M.F. (2007). O significado das crenças religiosas para um grupo de pacientes oncológicos em reabilitação. Revista Latino-Americana de Enfermagem, 15(1), Online.

Antoni, M. H., Lechner, S., Diaz, A., Vargas, S., Holley, H., Phillips, B.M., Carver, C S., \& Blomberg, B.. (2009) Cognitive behavior stress management effects on psychosocial and physiology adaptation in womwn undergoing treatment for breast cancer. Brain, Behavior, Immunology, 23(5), 580-592.

Apóstolo, J.L.A, Batista, A. C. , Macedo, C.M.C. \& Pereira, E.M.R. (2006). Sofrimento e conforto em doentes submetidas a quimioterapia. Referência, 2 839, 55-64.

Arranz, P., Barbero, J., Barreto, P. \& Bayés, R. (2008). Intervención emocional en cuidados paliativos: modelos y protocolos ( $3^{\mathrm{a}} \mathrm{ed}$.). Barcelona: Ariel.

Araújo, F., Monteiro, S., \& Torres, A. (2012). Intervenção psico-educativa em sobreviventes de cancro. In. J.L. Pais-Ribeiro, I. Leal, A. Pereira, \& Monteiro, A. (Orgs.). Psicologia da Saúde: desafios à promoção da saúde em doenças crónicas (pp.08-14). Lisboa: Placebo.

Araújo-Soares, V., McIntyre, T. (2002). É possível viver apesar da dor: avaliação da eficácia de programa de intervenção psicológica multimodal em pacientes com dor crónica. Psicologia, Saúde \& Doenças, 1(1), 101, 112.

Baile, W.F.(2011). Personality disorders in the oncology setting. Journal Support Oncology, 9 (2), 44-51.

Baltar, M., Ribeiro, J.P. et. al. (2001) Respostas emocionais, qualidade de vida e estratégias de coping para lidar com a doença em mulheres com cancro ginecológico. Psicologia: teoria, investigação e prática, 2, 285-300.

Balint, M. (1998). O médico, o seu doente e a doença. Lisboa: Climepsi. (Original publicado em 1956).

Barros, A.C (2008). Câncer de Mama. In. V. A. Carvalho, M. H. P. Franco, M. J. Kovács, R. Liberato, R. C. Macieira, M. T. Veit, M.J. B. Gomes \& L. Holtz Orgs. Temas em Psico-Oncologia (pp.15-19). São Paulo: Summus, pp.40-45.

Bayés, R. (1998ª). Paliación y avaluación del sufrimiento en la prática clínica. Medicina Clínica, 110(19), 740-743.

Bayés, R. (1998). Psicología del sufrimiento y de la muerte. Anuário de psicología, 29(4), 5-17.

Bayés, R. (2000). Los tiempos de espera en medicina. Medicina Clínica, 114(12), 464467.

Bayés, R. (2002). Timepo y enfermedad. Estudios de Psicología, 23(1), 100-110.

Bayés, R. (2003a). Después de muchos años: los tiempos de espera en ocnología. Psicooncología, O(1), 147-149.

Bayés, R. (2003b). La sociedad contemporânea anto del dolor y la muerte. Humanitas, Humanidades médicas, 1(1), 67-74.

Bayés,R. (2004). Alívio o incremento del dolor y el sufrimiento en el ámbito hospitalário: pequeños esfuerços, grandes ganacias. In. R. Bayés (Org.). Dolor y Sufrimiento en la prática clínica (pp.113-126). Barcelona: Fundación Medicina Y Humanidades. 
Bayés, R.S. (2009). Sobre la felicidad y sufrimiento. Quaderns de Psicología, 11 (1/2), 11-16.

Bayés. R. (2010). Aproximación a la histórya y perspetivas de la psicología del sufrimiento y de la muerte en España. Información Psicológica, 100, 7-13.

Benito, E., Maté, M.L. \& Pascual, A. (2011). Estratégias para la detécción, exploración y atención del sufrimiento en el paciente. Formación Médica Continuada, 18(7), 392-400.

Bennett, P. (2002). Introdução clínica à psicologia da saúde. Lisboa: Climepsi.

Bento, A. (2000). O sofrimento do doente internado em cuidados intensivos. Tese de mestrado em Ciências da Enfermagem. Instituto de Ciências Biomédicas Abel Salazar, universidade do Porto.

Bergeret, J. (1997 ). A personalidade normal e patológica. Lisboa: Climepsi.

Bergeret, J. (1997b). Introdução à psicopatologia geral. Lisboa: Climepsi.

Bonino, S. (2007). Mil amarras me prendem à vida: (com)viver com a doença. Coimbra: Quarteto.

Bourbeau, L. (2009). O teu corpo diz "ama-te": a metafísica das doenças e do malestar. Rio de Mouro: Círculo de Leitores.

Brancroft, A. (1991). As origens do sagrado: viagem espiritual à tradição ocidental. Lisboa: Editorial Estampa.

Brandt, J.A. (2009). Grupos Balint: suas especificidades e seus potenciais para uma clínica das relações do trabalho. Revista da SPAGESP - Sociedade de Psicoterapias Analíticas Grupais do Estado de São Paulo, 10(1), 48-55.

Bras-Chopard, A. (2007). As putas do diabo. Braga: Círculo de Leitores.

BrintzenhoSzoc, K. M., Levin, T T., Li, Y. Kissane, D. W., \& Zabona, J., R. (2009). Mixed anxiety /depression symptoms in a large cancer cohort: prevalence by cancer tipe. Psychosomatics, 50, 383-391.

Burgess, C., Cornelius, V., Love, S., Grahm, J., Richard, M., \& Ramirez, A. (2005). Depression and anxiety in women with breast cancer: five year observation cohort study. Britsh Medical Journal, 330(7493),702-705. DOI: 10.1136/bmj.38343.670868.D3

Burkberg, J., Penman, D., \& Holland, J.C. (1984). Depression in hospitalized cancer patients. Psychosomatic Medicine, 46, 199-212.

Cabet D.G., Cavaleiro, A.M., \& Pinteus, M.T. (2003). A visualização: uma intervenção possível em psicologia da saúde, Análise psicológica, 2(21), 195-200.

Canavarro, M. C. (1999). Inventário de sintomas psicopatológicos - B.S.I. In. M. R. Simões, M. M. Gonçalves \& L. S. Almeida (Orgs.). Testes e provas psicológicas em Portugal (vol. III) (pp. 95-109). Braga: SHO/APPORT.

Canavarro, M. C. (2007). Inventário de sintomas psicopatológicos (BSI): uma revisão crítica dos estudos realizados em Portugal. In. M. R. Simões, C. Machado, M. M. Gonçalves \& L. Almeida (Orgs.). Avaliação psicológica: instrumentos validadospara a população portuguesa (vol. III) (pp.305-331). Coimbra: Quarteto Editora. 
Cardoso, C. M. (1993). Recaídas e recidivas no tratamento das depressões. In. M. Taborda (Ed.). Psiquiatria e clínica geral. Porto: Colégio de Psiquiatria.

Carrol, B. T., Kathol, R. G., Noys Jr, R., Wald, T. G., \& Clam, G. H. (1993). Screening for depression and anxiety in cancer patients using the Hospital Anxiety and Depression Scale. General Hospital Psychiatry, 15(2), 69-74.

Carvalho, A. (2008). Trasntorno de ansiedade em pacientes com câncer. In. V. A. Carvalho, M. H. P. Franco, M. J. Kovács, R. Liberato, R. C. Macieira, M. T. Veit, M.J. B. Gomes \& L. Holtz (Orgs.). Temas em Psico-Oncologia (pp.257270). São Paulo: Summus.

Carvalho, M. (1996). A ajuda do médico no projecto existencial do doente. In. R.G. Lopes, V. Mota, \& C. Santos (Orgs.). A escolha de si-próprio: II Encontro de Antropologia Fenomenológica e Existencial. Porto: Hispital do Conde de Ferreira.

Carvalho-Teixeira, J.A. (2007) Psicologia da saúde. In. J. A. Carvalho Teixeira (Org.) Psicologia da saúde: contextos e áreas de intervenção (pp.17-41). Lisboa: Climepsi.

Carver, C. (1997) You want to measure coping but your protocol's too long: consider the brief COPE . International Journal of Behavioral Medicine, 4 (1), 92-100.

Carver, C.S., Pozo-Kaderman, C., Harris, S D., Noriega, V., Scheider, M. F., Robinson, D. S., Ketchman, A. S., Moffat, F. L., \& Clark, K. C.(1993). Hoe coping mediates the effect of optimism on distress: a study of women with early stage breast cancer. Journal Personality and Social Psychology, 65, 375-390.

Carver, C.S., Pozo-Kaderman, C., Harris, S D., Noriega, V., Scheider, M. F., Robinson, D. S., Ketchman, A. S., Moffat, F. L., \& Clark, K. C. (1994). Optimism versus pessimism predictors the quality of womens adjustment to early stage bresta cancer. Cancer, 73(4), 1213-1220.

Cassell, E.J. (1999). Diagnosing suffering: a perspective. Annals of Medicine International, 131(7), 531-534.

Cassell, E.J. (1991). Recognizing suffering. Hasting Cent Rep, 21, 24-31.

Cassell, E.J. (1982). The nature of suffering anda the goals of medicine. The New England Journal of Medicine, 309, 639-645.

Classen, C., Koopman, C., Angell, K., \& Spigel, P. (1996). Coping styles associated with psychological adjustment to advanced breast cancer. Health Psychology, 15(6), 434-437.

Chapman, C.R., \& Gravin, J. (1999). Suffering: the contributions of persistente pain. Lancet, 35 (3), 2233-2237.

Chapman, C.R., \& Gravin, J. (1993). Suffering and its relationship to pain Journal Paliative Care, 9, 5-13.

Ching, S.Y., Martinson, I.M. \& Wong, F.S. (2009). Reframing: psychological adjustment od chiniese woman at the beginning of breast cancer experience. Qualitative Health Research, 1(19), 339-351.

Clarke, S., Booth, L et. al. (2006) Social Support: gender differences in cancer patients in the United Kingdon. Cancer Nurs, 29 (1), 66-72. 
Crane, R. (2000). Cancro da Mama. In. Shirley \& Otto (Orgs.). Enfermagem em Oncologia (pp. 89-136).Loures: Lusociência.

Coimbra de Matos, A. (2003). Mais amor, menos doença: a psicossomática revisitada. Lisboa: Climepsi.

Collie, K., Kreshka, M.A., Ferrier, S., Parson, R., Graddy, K., Avram, S., et al. (2007). Videoconferencing for delivery of breast cancer support groups to women living in rural communities. A pilot study. Psycho-oncology, 16, 778-782.

Costa, S., Jimenéz, F., \& Pais-Ribeiro, J. L. (2010, Fevereiro) Análise dos acontecimentos de vida significativos decorrentes do adoecer de cancro da mama. Comunicação apresentada no Congresso Nacional de Psicologia da Saúde, Lisboa, Portugal.

Costa, A., \& Patrão, I. (2009). "Mamas de Cristal": sexualidade e imagem corporal em mulheres mastectomizadas. In. S. N. Jesus, I. Leal, \& M. Resende (Orgs.) Experiências e Intervenções em Psicologia da Saúde: Resumos e Textos. Faro: Universidade do Algarve, p. 1214.

Coward, d.D. (1990). The lived experience of self-trascendence in woman with advanced breast câncer. Nursing Science Quarterly, 3(4), 162-169.

Coyne, J.C., Hanisch, L.J. \& Palmer, S.C. (2007). Psychotherapy does not promote survivol (Kissane et al, 2007): now what? Psycho-oncology, 16, 1050-1052.

Cruz, J.P. (2007). A mente e o corpo ma saúde mental contemporânea. In. M.M. Siqueira, S.N.Jesus, \& V.B.Oliveira (Orgs.) Psicologia da saúde: teorias e pesquisa. São Paulo: Universidade Metodista.

Culos-Reed, S.N., Carlson, L.E, Daroux, L.M., \& Hately-Aldous, S. (2006). A pilot study of yoga breast cancer survivors a physical and psychological benefits. Psycho-oncology, 15 (10), 891-897.

Damásio, A. (1995). O erro de Descartes. (14ª ed.). Mem Martins: Europa-América.

Danhauer, S. C., Crawford, S. L., et ál. (2009) A longitudinal investigacion of coping strategies anda quality of live among younger womwn with breast cancer. Journal Behavior Medicine, 32(4), 371-379.

Danner, D., Snowdon, D., \& Friesen, W. (2001). Positive emotions early in life and longevity: findings from the nun study. Journal of Personality and Social Psychology, 80, 804-813.

Derogatis, L. R. (1975). Brief Symptom Inventory. Baltimore, MD: Clinical Psycgometric Research.

Derogatis, L. R. (1993). Brief Symptom Inventory. Administration, Scoring, and Procedures Manual ( $4^{\text {th }}$ Ed.). Minneapilis: Nacional Computers Systems.

Derogatis, L.R., Abelof, M.D., \& Melisanatos, N. (1979). Psychological coping machanisms and survivol time in metastatic bresat cancer. J.A.M.A. 242, 15041507.

Derogatis, L.R., Marnow, G.R., Fetting, J., Pennan, P., Piasetssy, S., Sahmale, A.M., Henrichs, D., \&carnicke, C.L. (1983). The prevalence of psychiatric disorders among cancer patients. JAMA, 249(6), 751-757. 
Devine, D., Parker, P. A., Fouladi, R. T. \& Cohen, L. (2003). The association betwen social support, intrusive thoughts, avoidance and adjustment following experimental cancer treatment. Psycho-Oncology 12, 453-462.

Dias, M.R. (2005). A esmeralda perdida: a informação prestada ao doente oncológico. Lisboa: Climepsi.

Dias, M. R.; Manuel, M.; Xavier, P. \& Costa, A. C. (2001). O Cancro da Mama no «seio» da família. In M.R. Dias \& E. Durá (Orgs.) Territórios da Psicologia Oncológica. (pp. 303-320) Lisboa: Climepsi.

Dicionário de Língua Portuguesa (1999). (8 ed.). Porto: Porto Editora.

Didion, J. (2006). O ano do pensamento mágico. São Paulo: Nova Fronteira.

Doolittle, M., \& Holland, J.C. (2011). Challenging personalities in the oncology setting. Journal Support Oncology, 9(2), 53-58.

Doron, R. \& Parot, F. (2001). Dicionário de Psicologia. Lisboa: Climepsi.

Durá, E., \& Dias, M. R. (1997) Relação médico-doente em psicologia oncológico: aspectos éticos, sociais e legais. Psicologia: Teoria, Investigação e Prática, 2, 197-208.

Durá, E. \& Hernández, S. (2001). Programas de apoyo social para enfermos oncológicos. In. M.R. Dias \& E. Durá (Orgs.). Territórios da Psicologia Oncológica (pp. 453-479). Lisboa: Climepsi.

Durá, E. \& Ibáñez, E. (2000). Psicologia Oncológica. Perspetivas futuras de investigação e intervenção profissional. Psicologia, Saúde \& Doenças, 1 (1), 27 43.

Elkins, G., Marcus, J., Stearns, V., \& Rajas, M.H. (2007). Pilot evaluation of hypnosis for the treatment of the flashes in survivors. Psycho-oncology, 16, 487-492.

Eliade, M. (1957). Mitos, sonhos e mistérios. Lisboa: Edições 70.

Epping-Jordan, J., Campus, B., Osowiecki, D., Oppedisano, G., Gerhardt, C., Primo, K., \& Knag, D. (1999). Psychological adjustment in breast cancer: processes of emotional distress. Health Pschological, 18(4), 315-320.

Estés, C. P. (2004). Mulheres que correm com lobos: mitos e histórias do arquétipo da mulher selvagem. Lisboa: Rocco.

Eyiogor, S., Karapolat, H., Yesil, H., Uslu, R., \& Duemaz, B. (2010). Effects of pilates exercises on fucntional capacity, flexibility, fatigue, depression and quality of life in the female breast cancer patients: a randomized controlled study. European Journal of Physical and Rehabilitation Medecine, 46(46), 481-487.

Fann, J. R., Thomas-Rich, A. M., Katon, W J., Cowley, D., Pepping, M., McGregor, B., Gralow, J. (2008). Major depression after breast cancer. A review of epidemiology and treatment. General Hospital Psychiatry, 30(2), 112-126.

Faria, C. \& Xarepe, F. (2000). Dor no peito; mal de amor. In. J. L. P. Ribeiro; I. Leal, \& M.R. Dias. Actas do $3^{\circ}$ congresso Nacional de Psicologia da Saúde (pp. 241252). Lisboa: ISPA

Faul, J.A, Heather, S.J., Williams, C., Leftus, L. \& Jacobsen, P.B. (2009). Relationships of stress management skill to psychological distress and quality of life in adults 
with cancer. Psycho-Oncology - Published online in Wiley Interscience (www.intersceience.wiley.com) DOI:10.1002/pan.1501.

Fernandes, S. M. R. (2009) Preditores psicossociais do ajustamento à doença e tratamento em mulheres com cancro da mama: o papel do estado emocional, das representações de doença, do otimismo e dos benefícios percebidos. Tese de doutoramento não publicada. Doutoramento em Psicologia: área do conhecimento em Psicologia da Saúde. Universidade do Minho.

Fernandes, S. \& McInteyre, T. (2002). Avaliação da Eficácia de um Programa de Intervenção Psicológica Breve em Mulheres com Cancro da Mama. Psicologia: Teoria, Investigação e Prática. 2, 359-370.

Figueiredo, A. P. \& Pereira, M.G. (2007).Impacte Psicológico do Tratamento do Cancro no Doente e Cônjuge. In M.G. Pereira (Org.). Psicologia da Saúde Familiar: aspetos teóricos e investigação (pp. 163-183). Lisboa: Climepsi.

Filazoglu, G. \& Griva, K. (2008) Coping and social support and healt related quality of life in woman with breast cancer in Turkey. Psychological Health Medicine, 13(5), 559-573.

Flaming, M. (2003). Dor sem nome: pensar o sofrimento. Porto: Edições Afrontamento.

Forner, E., Hernández, P., Lluch, A., García-conde, J., \& Ibañez, E. (1986). Sistema de valores e ideas irracionales en pacientes oncológicos. Anales de Psiquiatría, 2, 36-42.

Frankl, V. (2008). Em busaca de sentido. (29 ed.). Petróploes: Vozes. (Original publicado em 1977).

Freitas, C.H.B., \& Souza, C.B. (2004). Dizer, não dizer, como dizer: eis a questão. In. J. Ribeiro, \& I.Leal (Orgs.). Actas do $5^{\circ}$ Congresso Nacional de Psicologia da Saúde (pp.559-565). Lisboa: Fundação Caloust Gulbenkian.

Gadler, D. (2005). Emotional expression on health-related quality of life and cognitive processing in earl-stage breast cancer patients: an exploratory study. Unpublished doctoral dissertation, Alliant International University, San Diego.

Gallagher, J., Parle, M., \& Cairns, D. (2002). Appraisal and psychological distress six month after diagnosis of breast cancer. Britsh Journal of Health Psychology, 7, 365-376.

Gameiro, M.G.H. (2000). IESSD: um instrumento para a abordagem do sofrimento na doença. Referência (4), 57-66.

Gameiro, M.G.H. (1999).O sofrimento na doença. Coimbra: Quarteto.

Ganz, P. A., Schag, C. A., Lee, J J., Lolinsky, M. L., \& Tan, S. J. (1992). Cancer rehabilitación evaluation systyem short-form (CARES-SF): a cáncer specifc rehabilitation and quality of live instrument. Cancer, 69, 1406-1413.

Garafalo, J. P., Choppala, S., Hamann, H., \& Gjender, J. M. (2009) Uncertainty during the transition from câncer patient do survivor. Cancer Nursing, 32(4), 8-14.

Gil, F., Sirgo, A., Lluch, P., Maté, J. \& stradé, E. (2001). Intervención psicológica en pacientes de cáncer. In. M. R. Dias \& E. Durá (Orgs.). Territórios da Psicologia Oncológica (pp. 427-452). Lisboa: Climepsi. 
Gilbar, O. (1997). Women with high risk for breast cancer: psychological symptoms. Psychological Reports, 80(3), 800-802.

Giovagnoli, A., Meneses, R., \& Silva, A. (2006). The contribution of spirituality to quality of life in focal epilepsy. Epilepsy \& Behavior, 9(1), 133-139.

Golden-Kreutz, D. M., \& Anderson, B. L. (2004). Depressive symptoms after breast cancer sugery: relationships with global, cancer related, and life event stress. Psychooncology, 13(3), 211-220

Gonçalves, J. F. (2011). Controlo de Sintomas no cancro avançado. (2 $2^{\mathrm{a}}$ ed.). Lisboa: Coisas de Ler.

Gottlies, B.H., \& Wachola, E.D. (2007). Cancer support groups: a critical review of empirical studie. Psycho-oncology, 16, 379-400.

Gouveia, P. \& Tapadinhas, A. R. (2008) "E depois da tempestade ... A Bonança?” As emoções e o cancro da mama: um estudo comparativo. Psicologia, Saúde \& Doenças, 9 (S1), p.16 [Abstract].

Graner, K.M., Cezar, L.T.S., \& Teng, C.T. (2008). Trasntornos de humor em psicooncologia. In. V. A. Carvalho, M. H. P. Franco, M. J. Kovács, R. Liberato, R. C. Macieira, M. T. Veit, M.J. B. Gomes \& L. Holtz (Orgs.) Temas em PsicoOncologia (pp. 243-256). São Paulo: Summus.

Green, B. L., Krupnick, J. L., Rowland, I., \& Stern, N. (2000). Trauma history as predictive of psychologic symptoms in woman with breast cancer. Journal of Clinical Oncology, 18(5), 1084-1093.

Greer, S., \& Morris, T. (1975). Psychological attributes of woman who develop breast cancer: a controlled study. Journal of Psychosomatic Research, 19(2), 147-153. DOI: $10.1016 / 0022.3999(75) 90062-8$

Greer, S., \& Morris, T. (1978). The study of psychological factors in breast cancer: problems of method. Social Sciences \& Medicine: Part A: Medical Psychology \& Medical Sociology, 12, 129-134.

Greer, S., Morris, T., \& Pettingale, K.W. (1979). Psychological responses to breast cancer: effect on outcome. Lancet, 2, 785-787.

Guerra, M.P. \& Lima, L. (2005). Intervenção psicológica em grupos em contextos de saúde. Lisboa: Climepsi.Guimarães_Lopes, R. (1997). Ansiedade: ensaio de antropologia fenomenológica. In. R. Guimarães-Lopes, V. Mota, \& C. Santos (Orgs.). A escolha de si próprio: II Encontro de Antroplogia Fenomenológica e Existencial. Hospital do Conde Ferreira: Porto.

Guimarães-Lopes, R., \& Santos, F. (2008). Intencionalidade na comunicação em Grupos Balint. Revista Portuguesa de Clínica Geral, 24, 519-525.

Guimarães-Lopes, R. (2005). Psicologia da pessoa e elucidação psicopatológica. Porto: Higiomed.

Guimarães-Lopes, R. (1993). Clínica psicopedagógica: perspetivas da antropologia fenomenológica existencial. Porto: Hospital do Conde de Ferreira.

Guimarães, S.S. (1999). Introdução ao estudo da dor. In. M.M.J. Carvalho (Org.). Dor: um estudo multidisciplinar, (pp. 13-30). São Paulo: Editora Sumus.

Gupta, S. (2010). Enganar a morte. Alfragide: Lua de Papel. 
Hall, A., A`Hern, R., \& Fallowfield, L. (1999). Are we using appropriate self-report questionnaires for avaluation of anxiety and depression in woman with breast cancer? Eurpean Journal of Cancer, 35, 79-85.

Hanbor, F. A., Sumar, V. J., Rummans, T. A. et al. (2002). Physical, psychological and social well-being of women with breast cancer: the influence of disease phase. Psycho-oncology, 9(3), 221-231.

Harrison, J., \& Maguire, P. (1995). Influence of age on psychological ajustment of cancer. Psycho-oncology, 4, 33-38.

Hartl, K., Engel, J., Henschbach, P., Reinecker, H., Sommer, H., \& Friese, K. (2010). Personality of life over 2 years following breast cancer diagnosis and psychological impact factors. Psycho-oncology, 19, 160-169. DOI: 10.1002/pon.1536.

Hebert, R., Zdaniuk, B. et. al. (2009) Positive and negative religious coping and wellbeing in womwn with breast cancer. Journal Palliative Medecine, 12(6), 537545.

Heppner, P. P.,Armen, J. M. et ál. (2009) Problem-solving style and adapation in breast cancer survivors. a prospective analysis. Journal Cancer Survivors, 3(2), 128136 .

Herllich, C. (2004). Saúde e doença no início do século XXI - entre a experiência privada e a esfera pública. PSYSIS: Revista de Saúde Colectiva, 14(2), 383-394.

Hilakivi-Clarke, L, Rawland, J., Clark, R. \& Lippman, E. (1994). Psychosocial factors in the development and progression of breast cancer. Breast Cancer Research ana Treatment, 29(2), 141-160. DOI: 10.1007/BF00665676.

Hilakivi-Clarke, L., Wright, A., \& Lippman, M. E. (1993). DMBA-introced mammary tumor growth in mats exhibiting increased or decreabed ability to cope with stress due to early post natal handing or antidepressant treatment. Psychology Behavior, 54, 229-236.

Hoffmann, F. S., Muller, M. C. \& Frasson, A. L. (2006). Repercussões psicossociais, apoio social e bem-estar espiritual em mulheres com câncer de mama. Psicologia, Saúde \& Doenças, 7(2), 239-254.

Holahan, C., \& Moos, R. (1987) Personal and Contextual Determinants of Coping Strategies. Journal of Personality and Social Psychology, 52(5), 946-955.

Holland, J.C. (1998). Psycho-oncology. New York: Oxford University Press.

Holland, J.C. (2002). Hostory og psycho-oncology: overcoming attitudinal and conceptual barriers. Psychosomatic Medicine, 64, 206-221.

Holland, J.C. \& Mastrovito, R. (1980) Psychologic adaptation to breast cancer. Cancer, $46,1045-1052$.

Ibáñez, E., Valiente, M. \& Soriano, J. (2001). Una Historia de la psico-Oncología: del cáncer a la Psicolgía e vice-versa. In. M. R. Dias \& E. Durá (Orgs.). Territórios da Psicologia Oncológica (pp. 347-380). Lisboa: Climepsi.

Instituto Nacional Contra o Câncer. (2004). TNM - Classificação de Tumores Malignos. $6^{\mathrm{a}}$ ed. / traduzido por Ana Lúcia Amaral Eisenserg. Rio de Janeiro: INCA. Original: International Union Against Cancer. (2002). TNM: Classification of Malignant Tumours (6th. Ed.). L.H. Sobin \& C.H. Wittekind. 
Instituto Português de Oncologia de Francisco Gentil (2007). Registo Oncológico Nacional 2001. Porto: Instituto Português de Oncologia do Porto Edições.

Instituto Português de Oncologia do Porto (2008). Registo Oncológico Regional do Norte - RORENO2007. Porto: Instituto Português de Oncologia de Francisco Gentil - Centro Regional de Oncologia do Porto Edições.

Instituto Português de Oncologia do Porto (2009).Registo Oncológico Regional do Norte - RORENO 2005. Porto: Instituto Português de Oncologia do Porto Edições.

Instituto Português de Oncologia do Porto (2011). Registo Oncológico Regional do Norte - RORENO 2007. Porto: Instituto Português de Oncologia do Porto Edições.

Instituto Português de Oncologia do Porto (2011). Registo Oncológico Regional do Norte - RORENO. Folha Informativa: sobrevivência de doentes oncológicos diagnosticados entre 2000 e 2006 - Região Norte de Portugal - tumores da mama. Porto: Instituto Português de Oncologia do Porto Edições. Acedido em 02 de Agosto de 2012 e, http://www.roreno.com.pt/estatisticas/documentos/html.

International Agency for Research on Cancer (2009). About cancer Mondial. Acedido a 08 de Setembro de 2009 em http://www.-dep.iarc.fr

Iwamitsu, Y., Shimoda, K., Abe, H., Tani, T., Kodama, M., \& Okowa, M. (2003). Diferences in emotional distress setween breast tumor patients with emotional inhibition and those with emotional expression. Psychiatry and Clinical Neuroscience, 57, 289-294.

Jacobs, J., \& Bovass, G. (2000). Early and chronic stress and their relation to breast cancer. Psychological Medicine, 30, 669-678.

Jenkins, VA, Faloowfield LJ, Shilling V, Howell A. (2002) Does hormone therapy for the treatment of breast cancer have a detrimental effect on memory and cognition? Breast Cancer Research and Treatment, 76 (S1), p.548 [Abstract].

Jesse, Bering. (2011). O instinto de acreditar: A psicologia das almas, o destino e o sentido da vida. Maia: Círculo de Leitores.

Joyce-Moniz, L., \& Barros, L. (2005). Psicologia da doença para os cuidados de saúde: desenvolvimento e intervenção. Porto: Edições ASA.

Juánez, M., Río-Valle, S., \& Peña, P. (2006). En busca de una definición transcultural se sufrimiento: una revisión bibliográfica. Cultura de los cuidados, 10(20), 117120.

Justo, J. M. (2001). Uma Perspetiva Psicológica sobre as Doenças Oncológicas: etiologia, intervenção e articulações. In. M. R. Dias \& E. Durá. Territórios da Psicologia Oncológica (Orgs.). (pp. 51-73). Lisboa. Climepsi.

Keays, K.S., Harris, R.R., Lucyshyn, J.M., \& MacIntyre, D.L. (2008). Effects of pilates exercises on shulder range of motion, pain, mood, and upper-extremity function in women living with breast cancer: a pilot study. Physical Therapy, 88, 494510.

Kissane, D.W., Grabsch, B., Bloch, S., Snyden, R.D., \& Li, Y. (2007). Psychooncology, 16, 277-286. 
Kneier, A.W., \& Temoshk, L. (1984). Represive coping reactions in patients with malignant melanoma as compared to cardiovascular desease patients. Journal oh Psychosomatic Research, 28(2), 145-155. DOI: 10.1016/022-3999(84)9008-4

Koening, H. (2002). Religion, congestive hearth failure and chronic pulmonary disease. Journal of religion and health, 41(3), 263-278.

Krantz, K.A., \& Hedges, J. (1987). Persoanlity and health in the 1980`s: psychossomatic medicine revisited?. Journal of Personality, 55(2), 359-375.

Krikorian, A.1., Limonero, J. \& Maté, J. (2011). Suffering and distress at the end-of-life. Psycho-oncology (Published online in wiley online library- DOI: 10.1002/for 2087.

Kubler-Ross, E. (2008). Acolher a morte. Cruz Quebrada. Estrela Polar (original Publicado em 1969).

Kubler-Ross, E. (2008). A roda da vida: memórias da vida e da morte. Cruz Quebrada: Estrela Polar. (Obra original publicada em 1997).

Landis, S.H., Murray, T., Bolden, S., \& Wingo, P.A. (1999). Cancer statistics, 1999. CA. Cancer Journal for Clinicals, 49, 8-31.

Larousse Nova Enciclopédia (1997). (Vol.2). Lisboa: Círculo de Leitores.

Larousse Nova Enciclopédia (1999). (vol. 22). Lisboa: Círculo de Leitores.

Leal, I. (2006) Perspetivas em psicologia da saúde: dez anos da Sociedade Portuguesa de Psicologia da Saúde. In. I. Leal (Org.). Perspetivas em psicologia da saúde (pp.13-28). Lisboa: Climepsi.

Lehto, U. S., Ojanen, M., \& Kellokumpu-Lehtinen, P. (2005). Predictors of quality of life in newly diagnosed melanoma and breast cancer patients. Annals of Oncology, 16(5), 805-816.

Leite, M. R. F., \& Teng, C. T. (2008). Outros transtornos psiquiátricos em oncologia. In. V. A. Carvalho, M. H. P. Franco, M. J. Kovács, R. Liberato, R. C. Macieira, M. T. Veit, M.J. B. Gomes \& L. Holtz (Orgs.).Temas em Psico-Oncologia (pp.257-270). São Paulo: Summus.

León-Pizarro, C., Gich, I., Barthe, E., Raviosa, A., Farrús, B., Casas, F., et al. (2007). A randomized trial of the effect of training in relaxation and guided imagery techniques in improving psychological and quality of life índices for gynecologica and breast câncer brachyterapy patients. Psycho-oncology, 16, 971-979.

Lesser, E. (2010). Renascer das cinzas: como os tempos dificeis nos ajudam a crescer. Alfragide. Livros d'Hoje.

Lewis, F.M., Cochnane, B.B.,Fletchen, K.A.,Zahlis, E.H., Shands, M.H., Gralow, J.R., Wu, S.M., \& Schmitz, K. (2008). Helping her heal: a pilot study of a educational counselling intervention for spouses of woman with breast cancer. Psychooncology, 17, 131-137.

Li, M., Fitzgerald, P., \& Rodin, G. (2012). Evidence-based treatment of depression in patients with cancer. Journal of Clinical Oncology, 11(30), 1187-1195. 
Liberato, R.P. \& Carvalho, V.A. (2008). Psicoterapia. In. V. A. Carvalho, M. H. P. Franco, M. J. Kovács, R. Liberato, R. C. Macieira, M. T. Veit, M.J. B. Gomes \& L. Holtz (Orgs.). Temas em Psico-Oncologia (pp.431-350). São Paulo: Summus.

Lieberman, M. (2007). The role of insight discosure in outcome for women in peendirected breast câncer groups: a replication study. Psycho-oncology, 16, 961964.

Liénard, A., Merckaert, I., Libert, Y., Delvalux, N., Manchal, S., Boniven, J., Etienne, A. M., Klastersky, J., Keynaert, C., Scalliet, P., slachmuylden, J. L., \& Razavi, D. (2006). Factors that influence cancer patients anxiety following a medical consultation:impact of a communication skills training programme for physicians. Annais of Oncology, 17, 1450-1458. DOI: 10.1093/annonc/mdl142

Liess, A., Simon, W., Yutsis, M., Owen, J., Diemme, K.A., Golant, M., \& Giese-Davis, J. (2008). Detecting emotional expression in face-to-face and on line breast cancer supports groups. Journal of Counsultting and Clinical Psychoterapy, 76(3), 517-523.

Lindholm, L., Rehnesfeld, A., Arman, M. \& Hamrin, E. (2002). Siognificant others experience of suffering when living with women with breast cancer. Scandinavian Journal of Caring Sciences, 16, 248-155.

Lobo Antunes, N. (2008). (4 ${ }^{\mathrm{a}}$ ed.). Sinto muito. Lisboa: Verso de Kapa.

Loeser, J.D. \& Melzack, R. (1999). Pain: and overview. The Lancet, 353, 1607-1609.

Lopes, V. \& Carvalho, M. (2009). Estudo da Relação entre a Imagem Corporal e as Estratégias de Coping com o Ajustamento Emocional e a Satisfação Sexual em Mulheres Submetidas a Cirurgia Radical e Parcial. In. S. N. Jesus, I. Leal \& M. Rezende (Orgs.). Actas do I Congresso Luso-Brasileiro de Psicologia da Saúde: experiências e intervenções em Psicologia da Saúde - resumos e textos (p.86). Centro Universitário de Investigação em Psicologia da Universidade do Algarve: Universidade do Algarve.

Lovibond, P., \& Lovibond, S. (1995). The structure of negative emotional states: comparasion of the depression anxiety stress scales (DASS) with the beck depression and anxiety inventories. Bahavior Research and Therapy, 33(3), 335343.

Lueboonthavatchi, P. (2007). Prevalence and psychosocial factos of anxiety and depression in breast cancer. Journal Medical Association of Thai, 90(10), 21642174.

Maia, M. (2009). Hepatite C: vivência da doença, do tratamento e da cura. In. L.S. Pareira \& C. Pussetti (Orgs.). Os saberes da cura: antropologia da doença e práticas terapêuticas (pp.53-77). Lisboa: ISPA.

Markes, M., Brockaw, T., \& REsch, K.L. (2009). Exercise for women reaciving adjuvant therapy for breast cancer (Review). Crochnane Breast Cancer Group. DOI: 10.1002/14651858.CD005001.pub.2.

Marques, C.B. (2004). Reunião Balint: "Participar num Grupo Balint é um investimento do bem-estar enquanto MF. Médico de Família, 62, 58-60.

Martínez, M.T. (1993). Fatores psicológicos en sujetos con cáncer de laringe. Ansiedad pré-operatória. Psiquis, 14, 360-371. 
Matthews, E. E. \& Cook, P. F. (2009) relationships among optimism, well-being, selftranscendence, coping and social support during treatment for breast cancer. Psychooncology, 18(7), 716-726.

Matos, P. \& Pereira, m. G. (2002). Psicoterapia com Doentes Oncológicos e Seus Familiares: Pertinência e Objetivos Gerais. In. M.G Pereira \& C. Lopes (Orgs.). O Doente Oncológico e a Sua Família. (pp. 27-56) Lisboa: Climepsi.

Maia, A. (2002). Emoções e sistema imunológico: um olhar sobre a psiconeuromunologia. Psicologia: Teoria, investigação e prática, 2, 207-225.

Mann, T. (2009). A montanha mágica. Alfragide: Dom Quixote.

Maraste, R., Brandt, L., Olsson, H., \& Ryde-Brandt, B. (1992). Anxiety and depression in breast cancer patients at start of adjuvant radiotherapy: relations to age and type of sugery. Acta Oncológica, 31(6), 641-643.

May, A.M., Duivenvoorden, H.J., Konstjens, I., Weent, J., Hoekstra-Weebens, H., Borne, B., et al. (2008). Psycho-oncology, 17, 917-925.

McIntyre, T. M. (2004). Perda e sofrimento na doença: contributo da psicologia da saúde. Psychologica, 35, 167-179.

McIntyre, T. M. (1995a). Abordagens psicológicas do sofrimento no doente. In. M.T. McIntyre \& C. Vila-Chã (Orgs.). $O$ sofrimento no doente: leituras multidisciplinares (pp.17-30). Braga: APPOR.

McIntyre, T. M. (1995b). Aspectos positivos do sofrimento. In. M.T. McIntyre \& C. Vila-Chã (Orgs.). O sofrimento no doente: leituras multidisciplinares (pp.125131). Braga: APPORT.

McIntyre, T. M. (1994). Psicologia da saúde: unidade na diversidade. In. T.McIntyre (Org.)., Psicologia da saúde: áreas de intervenção e perspetivas futuras (pp.1732). Braga: APPORT.

McIntyre, T.M, Fernandes, S., \& Pereira, M. G. (2001). Intervenção Psicossocial Breve em Situação Oncológica em Contexto de Grupo. In. M.R. Dias \& E. Durá (Orgs.). Territórios da Psicologia Oncológica. (pp. 281-302) Lisboa: Climepsi.

McIntyre, T.M., \& Gameiro, M. (1999). Inventário de experiências subjetivas de sofrimento na doença. In. A. Soares., S. Araújo., \& S. Caires (Orgs.). Avaliação Psicológica: formas e contextos (pp-730-736). Braga: APPORT.

Michelena, M. (2010). À noite sonhei que tinha peito. Lisboa: Esfera dos Livros.

Miguel, A., Marques, A. L., \& Tosi, S. D. (2009) Viver sem mama: discurso de mulheres mastectomizadas. In. S. N. Jesus, I. Leal, \& M. Resende (Orgs.) Experiências e Intervenções em Psicologia da Saúde: Resumos e Textos (pp.1513-1521). Faro: Universidade do Algarve.

Miller, J.E., \& Cohen, S. (2001). Review: psychological interventions have a narrow application in influencing immune responses. Health Psychology, 20, 47-63.

Milsztajn, R. (2010). A História dos seios. Rio de Janeiro: 7Letras.

Mitchell, A., J., Chan, M., Bhotti, H., Hulton, M., Grassi, L., Johansen, C., \& Header, N. (2011). Prevalence of depression, anxiety and adjustment disorder in oncological, heamatological, and palliative-care settings: a meta-analysis of 94 interview-based studies. Lancet Oncology, 12, 160-174. 
Mitchell, A. J., Lord, K., \& Symonds, P. (2012). Which symptoms are indicate of DSMIV depression in cancer settings? An analysis of the diagnostic significance of somatic and non-somatic symptoms. Journal Affect Disorders, 138 (1-2), 137148.

Montazer, A., Jarvandi, S., Haghight, S., Vahmahmooddi, M., Sajadian, A., Ebrahimi, M., \& Hajimahmoodi, M. (2001). Anxiety and depression in breast cancer patients before after participation in cancer support group. Patient Education and Counselling, 45(3), 195-198.

Montgomery, G. H., Bovbjerg, D. A. (2004). Presurgery distress and specific responses experiencies predict post sugery outcomes in sugery patients confronting breast cancer. Health Psychology, 23(4), 381-387.

Moreira, H., Silva, S., Amaral, A., \& Canavarro, M. C. (2009). O papel da intimidade conjugal na qualidade de vida da mulher com Cancro da mama. Psicologia, Saúde \& Doenças, 10(1), 127-147.

Moreira, H., Silva, S. \& Canavarro, M. C. (2008). Qualidade de vida e ajustamento psicossocial na mulher com cancro da mama: do diagnóstico à sobrevivência. Psicologia, Saúde \& Doenças, 9 (1), 165-184.

Morris, J., \& Royle, G. T. (1988). Offering patients a choice of sugery for early breast cancer: a reduction in anxiety and depression in patients and their husbands. Social Science \& Medicine, 26(6), 583-585.

Morris, T., Greer, S., Pettingale, K., \& Watson, M. (1981). Patterns of expression of anger and their psychological correlations in woman with breast cancer. Journal of Psychosomatic Research, 25(2), 111-117. DOI:10/1016/0022-3999(81)900982.

National Comprehensive Cancer Network (2010). RCCN Clinical Pratice Guidelines in Oncology: Breast Cancer Risk Redution. V-II. National Comprehensive Cancer Network, Inc.

National Comprehensive Cancer Network (2011). RCCN Clinical Pratice Guidelines in Oncology (NCCN Guideliness):Breast Cancer Screening and Diagnosis. V-I. National Comprehensive Cancer Network, Inc.

Nave, F. \& Neves, S. (2007). A Cultura Organizacional e as Competências da Família: Uma Perspetiva Ecológica da Psicologia da Saúde. In. M. M. Siqueira, S. N. Jesus \& V. B. Oliveira (Orgs.). Psicologia da Saúde: Teoria e Pesquisa (pp.151162). São Paulo: Universidade Metodista.

Neme, C.M.B. \& Bredariolli; N.R.B. (2010). Mulheres com cáncer de mama, de útero e de ovários: estudos clínicos de casos. In C.M.B. Neme (Org.) Psico-oncologia: caminhos e perspetivas (pp.99-147). São Paulo: Summus.

Neuber, L.M.B., Neme, C.M.B.,\& Uemura, G. (2010). A mulher cáncer de mama: estresse e conjugalidade. In C.M.B.Neme (Org.) Psico-oncologia: caminhos e perspetivas (pp.149- 168). São Paulo: Summus.

Northouse, L. (1989). A longitudinal study of the adjustment of patients and husbands to breast cancer. Oncology Nursing Forum, 16(4), 511-516.

Northrup, C. (1999). Corpo de mulher, sabedoria de mulher. Rio de Mouro: Círculo de Leitores. 
Ogden, J. (2004 ${ }^{\mathrm{a}}$ ). Psicologia da Saúde.(2 ed.). Lisboa: Climepsi.

Ogden, J. (2004b). Compreender o Cancro da Mama. Lisboa: Climepsi.

Okamuna, M., Yamawaki, S., Akechi, T., Taniguchi, K., \& Uchitomi, Y. (2005). Psychiatric disorders following first bresat cancer incurrence: prevalence, associated factos anda relationships to quality of live. Japan Journal Clinical Oncology, 35(6), 302-309. DOI: 10.1093/jjco/hyo97

Oliveira, A. F., \& Siqueira, M.M. (2009). Relação entre o Suporte Social Bem-Estar Subjectivo. In. S. N. Jesus, I. Leal, \& M. Resende (Orgs.) Experiências e Intervenções em Psicologia da Saúde: Resumos e Textos. Faro: Universidade do Algarve, p.301.

Oliveira, C. C. (2007). A medicina é uma Ciência? Uma interrogação filosófica. Pessoas e Sintomas, 3, 26-32,

Oliveira, C. C. (2009). Humanidades na formação médica: realidade ou farsa. Reflexão e Acção, 12(2), 225-242.

Organização Mundial de Saúde (OMS) (1998). Classificação de Trasntornos Mentais e de Comportamento da CID-10: critérios diagnósticos para pesquisa. Porto Alegre: Artes Médicas.

O`Shaughnessy J., Vukelja S., Savin M., Holmes F.A., Jones M., Royall D., George M., \& Von Hoff D. (2002) Impact of epoetin alfa on cognitive function, asthenia, and quality of live in womwn with breast cancer receiving adjuvant or neoadjuvant chemotherapy: analysis of 6-months follow-up data. Breast Cancer Research and Treatment, 76 (S1), p.550 [Abstract].

Payne, D., Hoffman, R., Theodoulou, M., Dobik, M., \& Massie, D. (1995). Secrrening for anxiety and depression in women with breast cancer. Psychosomatics, 40, 64-69.

Pais-Ribeiro, J.L. (2005). Introdução à psicologia da saúde. Coimbra: Quarteto.

Pais-Ribeiro, J.L. \& Rodrigues, A. P. (2004). Questões Acerca do Coping: a propósito do estudo de adaptação do Brief COPE. Psicologia, Saúde \& Doenças, 5(1), 315.

Pais-Ribeiro, J.L. (2009). Coping Estratégias para redução do stress. Executive Health and Wellness, 1 (9), 28-29.

Pais-Ribeiro, J.L., Honrado, A. \& Leal, I. (2004). Contribuição para o Estudo da Adaptação Portuguesa das Escalas de Ansiedade, Depressão e Stress (EADS) de 21 Itens de Levibond e Levibond. Psicologia, Saúde \& Doenças, 5 (2), 229-239.

Pais-Ribeiro, J.L. (2007). Avaliação em Psicologia da Saúde: Instrumentos Publicados em Português. Coimbra: Quarteto.

Pais-Ribeiro, J.L. (2008). Metodologia da Investigação em Psicologia e Saúde. (2a ed.) Porto: Livpsic.

Patrão, I. \& Leal, I. (2004a). Abordagem do impacto psicossocial no adoecer de cancro da mama. Psicologia, Saúde \& Doenças. 5 (1), 53-73.

Patrão, I. \& Leal, I. (2004b). Avaliação da personalidade em mulheres com cancro da mama segundo o modelo dos Big Five. In. J.Ribeiro, \& I. Leal (Orgs.).Actas do 
$5^{\circ}$ Congresso Nacional de Psicologia da Saúde (pp-539-544). Lisboa: Fundação Calous Gulbenkian.

Patrão, I., Leal, I., \& Maroco, J. (2008). Uma questão de “benefit finding”? O impacto do cancro da mama. In. I. Leal, J.L. Pais Ribeiro, I. Silva, \& S. Marques (Orgs.). Actas do $7^{\circ}$ Congresso Nacional de Psicologia da Saúde (pp.279-282). Porto: Universidade do Porto.

Patrão, I., Maroco, J., \& Leal, I. (2006). Validação do BSI numa amostra portuguesa de mulheres com cancro da mama. In. I. Leal, J. Pais-Ribeiro, \& S. N. Jesus (Orgs.). Actas do $6^{\circ}$ Congresso Nacional de Psicologia da Saúde (pp.395-399). Faro: Universidade do Algarve.

Paúl, C., \& Fonseva, A.M. (2001). Psicossociologia da saúde. Lisboa: Climepsi.

Pausch, R. (2012). A última aula. Barcarena: Marcador Editora.

Peçanha, D. L. (2008) Câncer: recursos de enfrentamento na trajectória da doença. In. V. A. Carvalho, M. H. P. Franco, M. J. Kovács, R. Liberato, R. C. Macieira, M. T. Veit, M.J. B. Gomes \& L. Holtz (Orgs.) Temas em Psico-Oncologia (pp. 209217). São Paulo: Summus.

Pennebaker, J.W., \& Seagel, J.D. (1999). Forming a story: the health benefits of narrative. Journal of Clinical Psychology, 55(10), 1243-1254.

Pennery, E., Speechley, V., \& Rosenfield, M. (2010). Cancro da Mama: resposta sempre à mão.Lisboa: Lidel.

Pereira, M.A. (2008). Comunicação de más notícias e gestão do luto. Coimbra: FORMASAU.

Pereira, M.G. (2011). Promoção da saúde psicossocial na doença. In. M.G. Pereira (Orgs.). Promoção da saúde psicossocial na doença: aspetos teóricos e intervenção (pp. 13-21). Viseu: Psicosoma.

Pereira, M. G. (2007) Família, saúde e doença: teoria, prática e investigação. In. J. A. Carvalho Teixeira (Org.) Psicologia da Saúde. Contextos e áreas de intervenção (pp. 251-271). Lisboa: Climepsi.

Pereira, M.G. (2007). "Psicologia da Saúde Familiar". In M.G. Pereira (Org.). Psicologia da Saúde Familiar: aspectos teóricos e investigação. Lisboa: Climepsi.

Pereira, M.G. \& Lopes, C. (2002). O Doente Oncológico e a Sua Família. Lisboa: Climepsi.

Pereira, A. M., Pereira, A. \& Rodrigues, V. (2009). Experiências de Vida: a mulher com cancro da mama. In. S. N. Jesus, I. Leal, \& M. Resende (Orgs.) Experiências e Intervenções em Psicologia da Saúde: Resumos e Textos. Faro: Universidade do Algarve, pp.88-99.

Pereira, A. M., Pereira, A. \& Rodrigues, V. (2009). Crenças de saúde e optimismo psicossocial no ratreio do cancro da mama. In. S. N. Jesus, I. Leal, \& M. Resende (Orgs.) Experiências e Intervenções em Psicologia da Saúde: Resumos e Textos. Faro: Universidade do Algarve, pp.100-108.

Peres, R., \& Santos, D. (2009). Funcionamento defensivo em mulheres acometidas por câncer de mama: especificidades de pacientes em remissão e pacientes em recidiva. In. S. N. Jesus, I. Leal, \& M. Resende (Orgs.) Experiências e 
Intervenções em Psicologia da Saúde: Resumos e Textos. Faro: Universidade do Algarve, pp.565-570.

Pestana, J. P., Etevens, D., \& Conboy, J. (2009) Qaulaidade de vida e cancro: o papel da espiritualidade. In. S. N. Jesus, I. Leal, \& M. Resende (Orgs.) Experiências e Intervenções em Psicologia da Saúde: Resumos e Textos. Faro: Universidade do Algarve, pp. 1484-1499.

Pettingale, K.W, Watson, M., \& Greer, S. (1985). The vality of emocional control as a trait in breast cancer patients. Journal of Psychosocial Oncology, 2(3-4), 21-30. DOI: $10.1300 / J 077 \mathrm{v} 02 \mathrm{n} 03$ _02

Pimenta, C. A. M., Koizumi, M. S., \& Teixeira, M. J. (2000). Dor crónica e depressão: estudo com 92 doentes. Revista Escola de Enfermagem Universidade de S. Paulo, 34, 76-83.

Pinto, C. A. \& Pais-Ribeiro, J.L (2007). Sobrevivente de cancro: uma outra realidade. Texto Contexto Enfermagem. 16 (1), 142-148.

Pinto, S., Silva, S., Moreira, H. \& Canavarro (2009). Crescimento Pós-Traumático em Mulheres Sobreviventes de Cancro da Mama. In. S. N. Jesus, I. Leal, \& M. Resende (Orgs.) Experiências e Intervenções em Psicologia da Saúde: Resumos e Textos (pp.488-503). Faro: Universidade do Algarve.

Portal de Oncologia Português (2012). Dados sobre os vários tipos de cancro. Acedido a 05 de Setembro de 2012, em: http://www.pop.eu.com/portal/publicogeral/tipos-de-cancro.html

Priestman, T.J., Priestman, S.G., \& Bradshaw, C. (1985). Stress and breast cancer. Britsh of Cancer, 51(4), 493-498. DOI: 10.1200/jco.2005.03.228

Purushotham, A D., Upponi, S., Klevesath, M. B., Bobraw, L., Millar, K., Myles, J. P., \& Duffy, S. W. (2005). Morbility after sentinel lymph node biopsy inprimary breast cancer: results from randomized controlled trial. Journal of Clinical Oncology, 23(19), 4312-4321.

Ramos, R.T. (2007). Somatização e transtornos de ansiedade. In. M.M.Siqueira, S.J. Jesus, \& V.B. Oliveira (Orgs.). Psicologia da Saúde: teoria e pesquisa (pp.1324). São Paulo: Universidade Metodista.

Raison, C. L., \& Miller, A. H. (2003). Depression in cancer: new developments regarding diagnosis and treatment. Biological Psychiatry, 54, 283-294.

Rasmussen, D.M., \& Elverdam, B. (2008). The meaning of work and working life after câncer: na interview study. Psycho-oncology, 17, 1232-1238.

Rebelo, A., Vicente, A., Gomes, S. \& Moisão, C. (2008) Patologia mamária: problemáticas psicológicas. Psicologia, Saúde \& Doenças, 9 (S1), 17 [Abstract].

Rehnsfeld, A.M., Lindholm, M.L. \& Hamarin, E. (2002). The face of suffering among woman with breast cancer beingin field of forces. Cancer nursing, 25 (2), 96103.

Reis, J., \& Fradique, F. (2004). Significações leigas de saúde e doença em adultos. Análise Psicológica, 3(22), 475-485.

Reiss, M. (2012). Lições de perda, lições de vida. Lisboa: Guerra \& Paz.

Remen, R.N. (1998). Histórias que curam (3 ${ }^{a}$ ed.). São Paulo: Ágora. 
Remondes-Costa, S., Jiménez, F., \& Pais-Ribeiro, J.L. (2012). Depois do adoecer da mama: o sentido e o significado da vida - dois casos clínicos de crescimento pessoal em terapia oncológica. In. J.L. Pais-Ribeiro, I. Leal, A. Pereira, A. Torres, I. Direito, \& P. Vargas (Orgs.). Actas $9^{\circ}$ Congresso de Psicologia da Saúde (pp.1200-1207). Lisboa: Placebo.

Remondes-Costa, S., Jiménez, F., \& Pais-Ribeiro, J.L. (2012). Grupo terapêutico com mulheres com cancro da mama em diferentes fases do curso da doença: expressar, entreajudar, resignificar, crescer e curar. In. J.L. Pais-Ribeiro, I. Leal, A. Pereira, A. Torres, I. Direito, \& P. Vargas (Orgs.) Actas $9^{\circ}$ Congresso de Psicologia da Saúde (pp.1195-1199). Lisboa: Placebo.

Reynolds, P., Hulley. S., Torres, M., Jacson, J., Boyd, P., \& Cohen, V. W. (2000). Use of coping statigies and breast cancer survivol: results from black/white cancer suvivol study. Amrican Journal of Epidemiology, 153, 757-763.

Ribeiro, F., Pereira, J., \& Cunha, M. (2012). Da inevitabilidade da dor à operacionalidade do sofrimento: estudo sobre a perceção de da doença, adesão aos tratamentos, sofrimento e resiliência em pacientes com dor crónica. In In. J.L. Pais-Ribeiro, I. Leal, A. Pereira, A. Torres, I. Direito, \& P. Vargas (Orgs.) Actas $9^{\circ}$ Congresso de Psicologia da Saúde (pp.1208-1215). Lisboa: Placebo.

Ribeiro, J.L.P. (1999). Escala de Satisfação com o Suporte Social (ESSS). Análise Psicológica, 3 (XVII), 547-558.

Ritterband, L M., \& Spielberger, C. D. (2001). Depression in a cancer patient populacion. Journal of Clinical Psychology in Medical Settings, 8(2), 85-93.

Roales-Nieto, J. G. (Ed.) (2004) Psicología de la Salud: aproximación histórica, conceptual y aplicaciones. Madrid: Pirámide.

Roales-Nieto, J.G.,Ríos, J.G., \& Coronado, J.L. (2004). Comportamiento como riesgo para transtornos cardiovasculares. In. J.G. Roales-Nieto (Orgs.). Psicología de la Salud: aproximación histórica, conceptual y aplicaciones (pp- 407-433). Madrid: Pirámide.

Rodrigues, P.A., Cunha, M.J., \& Pereira, J.P. (2012). Consequências emocionais de mulheres mastectomizadas. In In. J.L. Pais-Ribeiro, I. Leal, A. Pereira, A. Torres, I. Direito, \& P. Vargas (Orgs.) Actas $9^{\circ}$ Congresso de Psicologia da Saúde (pp.1455-1462). Lisboa: Placebo.

Rogers, C. (2001). Sobre o poder pessoal. (4⿳亠丷 ed.). São Paulo: Martins Fontes.

Rogers, C. (1985). Tornar-se pessoa. (7 ed.). Lisboa: Morais Editores.

Rogers, C., \& Kingrt, M. (1977). Psicoterapia e relações humana (Vol. 1). Belo Horizonte: Interlivros.

Rojas-May, G. (2006). Estratégias de intervención psicológica en pacientes con cáncer de mama. Revista de Medicina Clínica, 17 (4), 194-197.

Rossi, O., Carrozzino, F., \& Frosina, G. (1999). Age-independency of AP site incision capacity in women. Envinonmental and molecular mutagenesis, 34, 256-259.

Salinsky, J. (2008). Como os grupos Balint têm mudado nos últimos 57 anos: objetivos e expectativas.Revista Portuguesa de Clínica Geral, 24, 526-530. 
Santos, F. (1999). Tire essa mágoa do peito. São Paulo: Editora Gente.

Santos, C.S.; Pais-Ribeiro, J. \& Lopes, C. (2003). Estudo de Adaptação da Escala de Satisfação com o Suporte Social (ESSS) a pessoas com diagnóstico de doença oncológica. Psicologia, Saúde \& Doenças, 4(2), 185-204.

Sasdelli, E.N., \& Miranda, E.M.F. (1991). Ser: o sentido da dor na urgência e na emergência. In. V.A.Angerami-Camon (Org.). Psicossomática e a psicologia da dor. São Paulo: Thomson Learning.

Scharfetter, C.H. (1997). Introdução à psicopatológica geral. Lisboa: Climepsi.

Schaw, B., Han, J.Y., kim, E., Gaustafson, D., Hawkins, R., Cleany, J., mctavish, F., Pingree, S., Eliason, P., \& Lumpkins, C. (2007). Psycho-oncology, 16, 676-687.

Schoevers, M., Helgeson, V.S., Sanderman, R, \& Ranchor, A. (2009). Typer of social support matters for predicton of posttraumatic growth among cancer survivors. Psycho-Oncology - Published online in Wiley InterScience (www.interscinece.wiley.com) DOI: 10.1002/ pon. 1501.

Schottenfeld, D. \& Fraumeni-Jr J. (2006). (Editors). Cancer Epidemiology and Prevention (3th. Ed.). New York : Oxford University Press.

Schou, I., Ekeberg, O., Ruland, C. M., Sandvik, L., \& Kanesen, R. (2004). Pessimism as a predictor emotional morbility one year following breast cancer sugery. Psycgooncology, 13, 309-320.

Schou, I., Ekeberg, O., Kanesen, R., \& Sorenben, E. (2008). Psycgosocial intervention as a complement of routine breast cancer care - who participants and does it help? Psycho-oncology, 17, 716-720.

Seligman, M. (2008). Felicidade autêntica: os princípios da psicologia positiva. Rio de Mouro: Círculo de Leitores.

Sendersky; V., Gause, D., Sung J. \& Durham, NC (2002) Comparison of psychosocial status in patients with breast cancer and patients with other oncology diagnoses. Breast Cancer Researchand Treatment. 76 (1), 552 [Abstract].

Sheard, T., \& Maguire, P. (1999). The effect of psychological intervertions on anxiety and depression in cancer patients: results of two meta-analyses. Britsh Journal of Cancer, 80(11), 1770-1780. DOI: 10.1038/sj.bjc.6690596

Shofield, P., Butow, P., Tattersall, M., Beeney, L. \& Dunn, S. (2003). Psychological responses of patients receiving a diagnosis of cancer. Annais of Oncollogy, 14(1), 48-56.

Siegel, R., Naishadham, D., \& Jemal, A. (2012). CA Cancer Journal Clinical, 62(1), 10-29. Doi: 10.3322/20138.Epus2012.Jan4.

Silva, I., Pais-Ribeiro, J., \& Cardoso, H. (2006). Contributo para a adaptação da Hospital Anxietyand Depression Scale à população portuguesa com doença crónica. Psychologica, 41, 193-204.

Simões; L.M. (2008). O teu corpo não mente: ajudar a curar a pessoa não a doença. São Domingos de Rana: Anjo dourado. 
Siqueira, M. M. \& Padovam, V. A. (2007). Suporte Social. In. M. M. Siqueira, S. N. Jesus \& V. B. Oliveira (Orgs.). Psicologia da Saúde: Teoria e Pesquisa (pp 6584). São Paulo: Universidade Metodista.

Soares, A. J.A. \& Alves, M.G.P. (2006) Cortisol como variável em Psicologia da Saúde. Psicologia, Saúde \& Doenças. 7 (2), 165-177.

Sobral, H. (2006). Experiências subjetivas de sofrimento em doentes oncológicos: percepção da doença e religiosidade. Interacções (11), 147-162.

Soares, M. (2002). Qualidade de vida e esclerose múltipla. Tese de Mestrado em Psicologia da Saúde. Universidade do Porto.

Somano, E., Goldenstein, P., Ribeiro, L., Lewin, F., Filho, E., Soares, H., \& Giglio, A. (2004). Praying correlations with highen quality of life: results from a survey on complete mantary/alternative medicine use among a group of Brazilian câncer patients. São Paulo Medical Journal, 122(2), 60-63.

Sorró, R. (2009). O sofrimento como modelo cultural: uma reflexão antropológica sobre a memória religiosa na diáspora africana. In. L.S. Pareira \& C. Pussetti (Orgs.). Os saberes da cura: antropologia da doença e práticas terapêuticas (pp.33-51). Lisboa: ISPA.

Sousa, S.R., \& Pereira, M.G. (2011). Promoção da saúde psicossocial no tratamento do cancro da mama. In. M.G. Pereira (Orgs.). Promoção da saúde psicossocial na doença: aspectos teóricos e intervenção (pp. 294-344). Viseu: Psicosoma.

Stark, D. P. H., \& House, A. (2000). Anxiety in cancer patients. Britsh Journal of Cancer, 83(10), 1261-1267. DOI: 10.1054/bjoc.2000.1405

Stark, D., Kiely, M., Smith, A., Velikova, G., House, A., \& Selsy, P. (2002). Anxiety disorders in cancer patients: their nature, associations, and relation to quality of live. Journal of Clinical Oncology, 20(14), 3137-3148. DOI: 10.1200/jco.2002.08.549

Steffen, P., Hinderliter, A., Blumenthal, J., \& Sherwood, A. (2001). Religious coping, ethnicity, and ambulatory blood pressure. Psychosomatic Medicine, 63, 523-530.

Tannock I, Tchen N, Juffs H, Downie F, Chemerynsky I, Yi QL, Hu H, Clemons M, Crump M, Goss P, Tweedale M, \& Warr D. (2002) Fatigue, menopausal symptoms anda cognitive dysfunction associated with adjuvant chemotherapy: first year of a large prospective controlled study. Breast Cancer Research and Treatment, 76 (S1), p.549 [Abstract].

Tapadinhas, A.R. (2004). Alterações do humor face ao adoecer da mama. In. J.Ribeiro, \& I. Leal (Orgs.). Actas do $5^{\circ}$ Congresso Nacional de Psicologia da Saúde (pp.551-557). Lisboa: Fundação Caloust Gulbenkian.

Tavares, M.A. (1999). Introdução à Psico-oncologia. In. R.Guimarães-Lopes (Org.). Temas CL de Psiquiatria, Psicossomática e Psicologia. Grupo Português de Psiquiatria Consiliar-Ligação e Psicossomática.

Teixeira, M.J. (1999). Fisopatologia da dor. In. M.M.J. Carvalho (Org.). Dor: um estudo multidisciplinar (pp. 47-76). São Paulo: Summus.

Teixeira, R., \& Pereira, M.G. (2011). Promoção da saúde psicossocial ma doença oncológica. In. M.G. Pereira (Org.). Promoção da saúde psicossocial na doença: aspectos teóricos e intervenção (pp.23-113). Viseu: Psicosoma. 
Temoshok, L. (1987). Personality, coping style, emotion and cancer towards an integrative model. Cancer Surveys, 6, 545-567.

Temoshok, L., \& Brehen, H. (1988). Mind-body and behavior in cancer incidence. Advances, 5(4), 41-56.

Temoshok, L., Heller, B.W., Sagebiel. R.W., Blois, M.S., Sweet, D.M, DiClemente, R.J., \& Gold, M. L. (1985). The relationship of psychosocial factors to ptognostic indicators in cutaneous malignant melanoma. Journal of Psychosomatic Research, 29(2), 139-153.

Teng, C. T., Humes, E. C., \& Demetrio, F. N. (2005). Depressão e comorbilidades clínicas. Revista de Psiquiatria Clínica, 32(3), 149-159.

Thomas-MacLean, R. (2004). Memories of treatmente: the immediacy of breast cancer. Qulalitative Health Reserach, 1(14), 628-643.

Tjemsland, L., SØreide, J.A., Matre, R., \& Malt, U.F. (1997). Properative psychological variables predict immunological status in patients with operable breast cancer. Psycho-oncology, 6, 311-320.

Torres, A. (2012). Aplicabilidade e eficácia da intervenção de grupo na doença crónica: estudo com sobreviventes de cancro da mama. In. J.L. Pais-Ribeiro, I. Leal, A. Pereira, \& Monteiro, S. (Orgs.) Psicologia da Saúde: desafios á promoção da saúde em doenças crónicas (pp.261-269). Lisboa: Placebo.

Torres, A., Pereira, A., Monteiro, S., Pinto, A., Correira, A., Gonçalves, D. \& Ribeiro, L. (2010). A Saúde Mental das Mulheres Sobreviventes de Cancro da Mama Portuguesas. In. Pereira, H., Branco, L., Simões, F., Esgalhado, G., Afonso, R. M. (Orgs.).Educação para a Saúde, Cidadania e desenvolvimento Sustentado. (1092-1100) (ISBN 978-989-96996-0-1).

Trill, M.D., \& Holland, J. (1995). A model curriculum fot training in psycho-oncology. Psycho-oncology, 4, 169-182.

Trill, M.D. (2002). Cultura y cáncer. In. M.R. Dias, \& E. Durá. Territórios da psicologia oncológica (pp-639-651). Lisboa: Climepsi.

Trill, M.D. (2002). La formación en Psico-oncología. In. M.R. Dias, \& E. Durá. Territórios da psicologia oncológica (pp-381-398). Lisboa: Climepsi.

Ulla, S., \& Remor, E.A. (2002). Psiconeuroimunologia e infecção por HIV: realidade ou ficção? Psicologia: reflexão e crítica, 15(1), 113-119.

Urcuyo, K.R., Boyers, A. E., Carver, C. S., \& Antoni, M. H. (2005). Finfing benefit in breast cancer: relation with personality, coping, and concurrent well-being. Psychology and Health, 20(2), 175-192.

Vallejo, J. (1999). Transtornos de angustia. In. J. Vallejo (organizador). Introdución a la psicopatolgía y la psiquiatría (4a ed.). (pp.383-399). Barcelona: Masson.

Vallejo, J. (1999). Transtornos depressivos. In. J. Vallejo (organizador). Introdución a la psicopatolgía y la psiquiatría (4⿳亠丷⿵冂丶 $\mathrm{ed}$.). (pp.507-540). Barcelona: Masson.

Varela, M. \& Leal, I. (2007). Estratégias de coping em mulheres com cancro da mama. Análise Psicológica. 3 (25), 479-488.

Varela, M. \& Leal, I. (2008). Perturbação de pós-stress traumático, estratégias de coping e suporte social. In I. Leal, J.L.Pais Ribeiro, I. Silva \& S. Marques (Orgs.), Actas 
do $7^{o}$ Congresso Nacional de Psicologia da Saúde (pp. 13-32). Porto. Universidade do Porto.

Vásquez, I. A, Rodrigues, C. F. \& Álvarez, M. P. (1998). Manual de Psicología de la Salud. Madrid: Pirámide.

Vaz Serra, A. (2002). O Stress na Vida de Todos os Dias. (2 ${ }^{\mathrm{a}}$ ed.) Coimbra: Gráfica de Coimbra.

Vaz Serra (Director) Membros da Consulta de Risco, Clínica psiquiátrica dos H.U.C. (1991). Reações Emocionais à Doença Grave: como lidar.. Coimbra: Edição Psiquiatria Clínica.

Veit, M. T. \& Carvalho, V. A. (2008). Psico-Oncologia: definições e áreas de actuação. In. V. A. Carvalho, M. H. P. Franco, M. J. Kovács, R. Liberato, R. C. Macieira, M. T. Veit, M.J. B. Gomes \& L. Holtz (Orgs.) Temas em Psico-Oncologia (pp.15-19). São Paulo: Summus.

Walker, M., \& Podbilewicz-Schuller, Y. (2005). Preparation for breast cancer treatment planning: results of a randomized clinical trial. Psycho-oncology, 14, 408-420.

Watson, M., Greer, S., Rowden, L., Gorman, C., Robertson, B., Bliss, J.M., \& Tunnore (1991). Relationships between emotional control adjustment to cancer and depression and anxiety in breast cancer patients. Psychological Medicine, 21, 51-57.

Wtason, M., Haviland, J. S., Greer, S., Davidson, J., \& Bliss, J. M. (1999). Influence of psychological response on survivol breast cancer: a population-based cohort study. The Lancet, 354, 1331-1336.

Watson, M., Homewood, J., Haviland, J., \& Bliss, J. M. (2005). Influence of psychological response on breast cancer survival: 10 years follow uo of a population-based cohart study. European Journal of Cancer, 41, 1710-1714.

Wenzel, J. \& Stevens, R.H. (2008). Experiencing breast câncer in maneged care. Qualitative Health Research, 1(18), 1477-1488.

Wittekind, C., Greene, F. L., Hutter, R. V., Klimfinger, M. \& Sobin, L. H. (2004). TNM Atlas: TNM/pTNM Classification of Malignant Tumours. $\left(5^{\text {th }}\right.$. Ed.). New York: Springer.

Yalom, M. (1998). História do seio. Lisboa: Torema.

Zigmond, A. S., \& Snaith, R. P. (1983). The hospital anxiety and depression scale. Acta Oncológica, 67, 361-370. 
ANEXOS 
ANEXO 1 - Consentimento Informado 


\section{CONSENTIMENTO INFORMADO}

A presente investigação insere-se no âmbito do projecto de doutoramento a ser apresentado à Faculdade de Psicologia da Universidade de Salamanca, intitulada "Experiência Subjetiva de Sofrimento na Doença e Sintomatologia Psicopatológica em Mulheres com Cancro da Mama”.

O seu principal objetivo consiste em avaliar a experiência subjetiva de sofrimento na doença a presença de sintomatologia psicopatológica, e traçar um perfil psicológico em mulheres com cancro da mama em diferentes fases do curso da doença.

Papel dos Participantes: - a colaboração nesta investigação consiste:

a). No preenchimento de um conjunto de questionários.

Papel da Investigadora: - a investigadora compromete-se a:

a). Garantir a confidencialidade dos dados fornecidos pelos participantes;

b). Utilizar os dados recolhidos exclusivamente para efeitos de investigação;

c). A eventual desistência ou recusa em colaborar na investigação não tem qualquer consequência para os participantes. seguem):

Consentimento Informado do Participante (preencha os espaços que se

$\mathrm{Eu}$,

declaro ter conhecimento dos objetivos da investigação “Experiência Subjetiva de Sofrimento na Doença e Sintomatologia Psicopatológica em Mulheres com Cancro da Mama", e das implicações da minha participação, e aceito preencher o conjunto dos questionários.

Assinatura: 
ANEXO 2 - Questionário de Dados Sociodemográficos 


\section{Questionário de Dados Socio-demográficos}

\section{Idade:}

\section{Concelho de Residência:}

\section{Distrito:}

\section{Estado Civil:}

Coloque o número correspondente à resposta no espaço acima em branco $0=$ solteira; $1=$ casada; $2=$ separada/divorciada; $3=$ viúva; $4=$ união de facto

\section{Escolaridade:}

$0=$ não frequentou a escola; $1=1^{\circ}$ ciclo ( escola primária) incompleto; $2=1^{\circ}$ ciclo (escola primária) completo; $3=2^{\circ}$ ciclo $\left(5^{\circ}\right.$ e $6^{\circ}$ ano de escolaridade) $44=3^{\circ}$ ciclo $\left(7^{\circ}, 8^{\circ} 9^{\circ}\right.$ anos de escolaridade); $5=$ secundário $\left(10^{\circ}, 11^{\circ}, 12^{\circ}\right.$ anos de escolaridade $) ; 6=$ ensino técnico (médio ou profissional); $7=$ ensino superior ou universitário

\section{Profissão actual:}

\section{Situação ocupacional:}

$1=$ activo; $2=$ desempregado; $3=$ espera $1^{\circ}$ emprego; $4=$ baixa/atestado; $5=$ reformada; $6=$ doméstica; $7=$ estudante; $8=$ nunca trabalhou; $9=$ outros casos

\section{Agregado Familiar - Quem vive consigo?}

$0=$ só; $1=$ pais; $2=$ mãe e pai; $3=$ mãe ou pai e outra pessoa; $4=$ avós; $5=$ tios; $6=$ outros familiares; $7=$ pais adoptivos; $8=$ vive em instituição; $10=$ cônjuge; $11=$ cônjuge e filhos; $12=$ cônjuge, filhos e pais ou sogros; $99=$ outras situações 
ANEXO 3 - Questionário História da Doença Oncológica 

A - HISTÓRIA DA DOENÇA ONCOLÓGICA (Preenchimento pelo Clínico)

\section{DIAGNÓSTICO ONCOLÓGICO:}

\section{DIAGNÓSTICO REALIZADO EM:}

1. 1-3 meses

2. 3-6 meses

3. 6-12 meses

4. 12-24 meses

5. $>25$ meses

- Estadio do Tumor

1. Local

2. Loco-regional

3. Metastático

4. Desconhecido

\section{- Classificação TNM}

T - Tumor Primário

$\mathrm{Tx}-\mathrm{O}$ tumor primário não pode ser avaliado

To - Não há evidência de tumor primário

Tis - carcinoma in situ

$\underline{\text { Tamanho - T1, T2, T3, T4 }}$

- N - Linfonodos Regionais

$\mathrm{Nx}$ - Os linfonodos regionais não podem ser avaliados

No - Ausência de metástases em linfonodos regionais

Comprometimento crescente dos linfonodos regionais $-\mathrm{N} 1, \mathrm{~N} 2, \mathrm{~N} 3$

- M - Metástases à distância

Mx - A presença de metástases à distância não pode ser avaliada

Mo - Ausência de metástases à distância

M1 - Metástases à distância

- O Doente tem conhecimento do diagnóstico oncológico

1. Conhece

2. Suspeita

3. Ignora 
- Prognóstico

0. Bom

1. Razoável

2. Mau

3. Desconhecido

4. Fase terminal

- Sintomas Físicos

0 . Ausente

1. Dor

2. Astenia

3. Incapacidade funcional

4. Outros

- Tratamento Atual

0 . Nenhum

1. Radioterapia

2. Quimioterapia

3. Outros fármacos 
ANEXO 4 - Inventário de Experiências Subjetivas de Sofrimento na Doença (IESSD) 


\section{Inventário de Experiências Subjetivas de Sofrimento na Doença IESSD (Teresa McIntyre \& Manuel Gameiro, 1997)}

Data:............ ID:

Nome:

Abaixo encontram-se algumas afirmações que podem corresponder a experiências das pessoas doentes.Por favor indique até que ponto cada uma das afirmações corresponde (ou não) ao que verdadeiramente se passa consigo, marcando com uma cruz o respectivo quadrado tendo em conta a legenda abaixo apresentada. Não há respostas certas ou erradas. É na sua opinião que estamos interessados.

1-Não corresponde nada ao que se passa comigo/ é totalmente falso

2- Corresponde pouco ao que se passa comigo

3-Corresponde bastante ao que se passa comigo

4-Corresponde muito ao que se passa comigo

5-Corresponde totalmente ao que se passa comigo / é totalmente verdadeiro

1 - Sinto-me mais cansado/a desde que estou doente

2 - Penso muito na gravidade e nas consequências da minha doença

3 - Sinto-me apreensivo/a em relação ao que me poderá acontecer

4 - Sinto que a doença me está a roubar tempo para poder fazer aquilo que gostaria

5 - Sinto dificuldade em suportar o estado de tensão que a doença me provoca

6 - Desde que fiquei doente sinto-me triste

7 - Preocupa-me a ideia de a minha doença me poder fazer perder o emprego

8 - A doença obriga-me a pôr de lado alguns projectos importantes que tinha em mente

9 - Desde que estou doente tenho tido momentos de grande desespero

10 - Desde que estou doente tenho sentido mais a falta da minha família

11 - Tenho receio de que com minha doença me torne uma sobrecarga para a minha família

12 - Angustia-me a ideia de poder deixar as pessoas de quem gosto

13 - Não consigo compreender o que está a provocar a minha doença

14 - Com a doença tenho perdido muita da minha energia e força física

15 - A minha doença deixa-me desiludido/a em relação ao que esperava da vida

16 - Desde que estou doente sinto dificuldade em me controlar e reajo com agressividade

17 - Preocupo-me com as dores que possa vir a ter

18 - Tenho dificuldade em deixar de pensar nas coisas que me poderão acontecer

19 - Sinto-me revoltado/a perante a minha situação de doença

20 - Não consigo encontrar posição para estar confortável

21 - Sinto que com a doença perdi a liberdade de decidir sobre a minha vida

22 - A minha doença fez-me preocupar com o futuro das pessoas que me são queridas

23 - Tenho dores difíceis de suportar

24 - Apesar de estar doente sinto-me tranquilo/a

25 - Preocupa-me a ideia de não poder ajudar a minha família como antes de adoecer

26 - Apesar da minha doença não deixo de fazer planos para o futuro

27 - Sinto que já não sou capaz de fazer as mesmas coisas que conseguia fazer antes de adoecer

28 - A minha situação de doente faz-me sentir pena de mim próprio/a

29 - Acho que para mim já não vale a pena pensar no futuro.

30 - A doença faz com que em sinta diminuído/a como pessoa

\begin{tabular}{|l|l|l|l|l|}
\hline $\mathbf{1}$ & $\mathbf{2}$ & $\mathbf{3}$ & $\mathbf{4}$ & $\mathbf{5}$ \\
\hline $\mathbf{1}$ & $\mathbf{2}$ & $\mathbf{3}$ & $\mathbf{4}$ & $\mathbf{5}$ \\
\hline $\mathbf{1}$ & $\mathbf{2}$ & $\mathbf{3}$ & $\mathbf{4}$ & $\mathbf{5}$ \\
$\mathbf{1}$ & $\mathbf{2}$ & $\mathbf{3}$ & $\mathbf{4}$ & $\mathbf{5}$ \\
\hline $\mathbf{1}$ & $\mathbf{2}$ & $\mathbf{3}$ & $\mathbf{4}$ & $\mathbf{5}$ \\
\hline $\mathbf{1}$ & $\mathbf{2}$ & $\mathbf{3}$ & $\mathbf{4}$ & $\mathbf{5}$ \\
$\mathbf{1}$ & $\mathbf{2}$ & $\mathbf{3}$ & $\mathbf{4}$ & $\mathbf{5}$ \\
\hline $\mathbf{1}$ & $\mathbf{2}$ & $\mathbf{3}$ & $\mathbf{4}$ & $\mathbf{5}$ \\
\hline $\mathbf{1}$ & $\mathbf{2}$ & $\mathbf{3}$ & $\mathbf{4}$ & $\mathbf{5}$ \\
\hline $\mathbf{1}$ & $\mathbf{2}$ & $\mathbf{3}$ & $\mathbf{4}$ & $\mathbf{5}$ \\
\hline $\mathbf{1}$ & $\mathbf{2}$ & $\mathbf{3}$ & $\mathbf{4}$ & $\mathbf{5}$ \\
\hline $\mathbf{1}$ & $\mathbf{2}$ & $\mathbf{3}$ & $\mathbf{4}$ & $\mathbf{5}$ \\
\hline $\mathbf{1}$ & $\mathbf{2}$ & $\mathbf{3}$ & $\mathbf{4}$ & $\mathbf{5}$ \\
\hline $\mathbf{1}$ & $\mathbf{2}$ & $\mathbf{3}$ & $\mathbf{4}$ & $\mathbf{5}$ \\
$\mathbf{1}$ & $\mathbf{2}$ & $\mathbf{3}$ & $\mathbf{4}$ & $\mathbf{5}$ \\
\hline $\mathbf{1}$ & $\mathbf{2}$ & $\mathbf{3}$ & $\mathbf{4}$ & $\mathbf{5}$ \\
\hline $\mathbf{1}$ & $\mathbf{2}$ & $\mathbf{3}$ & $\mathbf{4}$ & $\mathbf{5}$ \\
\hline $\mathbf{1}$ & $\mathbf{2}$ & $\mathbf{3}$ & $\mathbf{4}$ & $\mathbf{5}$ \\
\hline $\mathbf{1}$ & $\mathbf{2}$ & $\mathbf{3}$ & $\mathbf{4}$ & $\mathbf{5}$ \\
\hline $\mathbf{1}$ & $\mathbf{2}$ & $\mathbf{3}$ & $\mathbf{4}$ & $\mathbf{5}$ \\
\hline $\mathbf{1}$ & $\mathbf{2}$ & $\mathbf{3}$ & $\mathbf{4}$ & $\mathbf{5}$ \\
\hline $\mathbf{1}$ & $\mathbf{2}$ & $\mathbf{3}$ & $\mathbf{4}$ & $\mathbf{5}$ \\
\hline $\mathbf{1}$ & $\mathbf{2}$ & $\mathbf{3}$ & $\mathbf{4}$ & $\mathbf{5}$ \\
\hline $\mathbf{1}$ & $\mathbf{2}$ & $\mathbf{3}$ & $\mathbf{4}$ & $\mathbf{5}$ \\
\hline $\mathbf{1}$ & $\mathbf{2}$ & $\mathbf{3}$ & $\mathbf{4}$ & $\mathbf{5}$ \\
\hline $\mathbf{1}$ & $\mathbf{2}$ & $\mathbf{3}$ & $\mathbf{4}$ & $\mathbf{5}$ \\
\hline $\mathbf{1}$ & $\mathbf{2}$ & $\mathbf{3}$ & $\mathbf{4}$ & $\mathbf{5}$ \\
\hline $\mathbf{1}$ & $\mathbf{2}$ & $\mathbf{3}$ & $\mathbf{4}$ & $\mathbf{5}$ \\
\hline $\mathbf{1}$ & $\mathbf{2}$ & $\mathbf{3}$ & $\mathbf{4}$ & $\mathbf{5}$ \\
\hline $\mathbf{1}$ & $\mathbf{2}$ & $\mathbf{3}$ & $\mathbf{4}$ & $\mathbf{5}$ \\
\hline & & & \\
\hline
\end{tabular}




\begin{tabular}{|c|c|c|c|c|c|}
\hline 31 - Sinto uma má disposição física que me impede de descansar & 1 & 2 & 3 & 4 & 5 \\
\hline 32 - Tenho receio de ficar com alguma deficiência física & 1 & 2 & 3 & 4 & 5 \\
\hline 33 - A minha doença causa-me angústia & 1 & 2 & 3 & 4 & 5 \\
\hline $\begin{array}{l}34 \text { - Preocupo-me com a possibilidade de não ser capaz de continuar a "ganhar o } \\
\text { pão" para a minha família }\end{array}$ & 1 & 2 & 3 & 4 & 5 \\
\hline 35 - O ver-me dependente dos outros tem-me sido difícil de suportar & 1 & 2 & 3 & 4 & 5 \\
\hline $\begin{array}{l}36 \text { - Desde que fiquei doente não consigo evitar certos comportamentos de que } \\
\text { não gosto }\end{array}$ & 1 & 2 & 3 & 4 & 5 \\
\hline 37 - Sinto que pouco posso esperar do meu futuro & 1 & 2 & 3 & 4 & 5 \\
\hline 38 - Acho que vou recuperar as minhas forças & 1 & 2 & 3 & 4 & 5 \\
\hline 39 - Desde que estou doente tenho sentido muitos medos & 1 & 2 & 3 & 4 & 5 \\
\hline $\begin{array}{l}40 \text { - Desde que fiquei doente sinto dificuldade em encontrar sentido para a minha } \\
\text { vida }\end{array}$ & 1 & 2 & 3 & 4 & 5 \\
\hline 41 - Tenho dores que não me deixam descansar & 1 & 2 & 3 & 4 & 5 \\
\hline 42 - Tenho esperança de ainda vir a realizar os meus sonhos & 1 & 2 & 3 & 4 & 5 \\
\hline 43 - Desejaria que a minha família não sofresse tanto por eu estar doente. & 1 & 2 & 3 & 4 & 5 \\
\hline 44 - Penso que vou melhorar. & 1 & 2 & 3 & 4 & 5 \\
\hline
\end{tabular}

Por favor verifique se respondeu a todos os itens antes de entregar o questionário.

Muito obrigado pela sua ajuda! 
ANEXO 5 -Inventário de Sintomas Psicopatológicos (BSI) 


\section{BSI}

L.R. Derogatis, 1993; Versão: M.C. Canavarro, 1995

A seguir encontra-se uma lista de problemas e sintomas que por vezes as pessoas apresentam. Assinale, num dos espaços à direita de cada sintoma, aquele que melhor descreve o GRAU EM QUE CADA PROBLEMA O INCOMUDOU DURANTE A ÚLTIMA SEMANA. Para cada problema ou sintoma marque apenas um espaço com uma cruz. Não deixe nenhuma pergunta por responder.

\begin{tabular}{|c|c|c|c|c|c|}
\hline $\begin{array}{l}\text { Em que medida foi incomodado } \\
\text { pelos seguintes sintomas: }\end{array}$ & Nunca & $\begin{array}{c}\text { Poucas } \\
\text { vezes }\end{array}$ & $\begin{array}{c}\text { Algumas } \\
\text { vezes }\end{array}$ & $\begin{array}{c}\text { Muitas } \\
\text { vezes }\end{array}$ & $\begin{array}{c}\text { Muitíssimas } \\
\text { vezes }\end{array}$ \\
\hline \multicolumn{6}{|l|}{ 1. Nervosismo ou tensão interior } \\
\hline \multicolumn{6}{|l|}{ 2. Desmaios ou tonturas } \\
\hline \multicolumn{6}{|l|}{$\begin{array}{l}\text { 3. Ter impressão que as outras } \\
\text { pessoas podem controlar os meus } \\
\text { pensamentos }\end{array}$} \\
\hline \multicolumn{6}{|l|}{$\begin{array}{l}\text { 4. Ter a ideia que os outros são } \\
\text { culpados pela maioria dos seus } \\
\text { problemas }\end{array}$} \\
\hline \multicolumn{6}{|l|}{$\begin{array}{l}\text { 5. Dificuldade em se lembrar de } \\
\text { coisas passadas ou recentes }\end{array}$} \\
\hline \multicolumn{6}{|l|}{$\begin{array}{l}\text { 6. Aborrecer-se ou irritar-se } \\
\text { facilmente }\end{array}$} \\
\hline \multicolumn{6}{|l|}{$\begin{array}{l}\text { 7. Dores sobre o coração ou no } \\
\text { peito }\end{array}$} \\
\hline \multicolumn{6}{|l|}{ 8. Medo na rua ou praça pública } \\
\hline \multicolumn{6}{|l|}{$\begin{array}{l}\text { 9. Pensamento de acabar com a } \\
\text { vida }\end{array}$} \\
\hline \multicolumn{6}{|l|}{$\begin{array}{l}\text { 10. Sentir que não pode confiar na } \\
\text { maioria das pessoas }\end{array}$} \\
\hline \multicolumn{6}{|l|}{ 11. Perder o apetite } \\
\hline \multicolumn{6}{|l|}{$\begin{array}{l}\text { 12. Ter um medo súbito sem razão } \\
\text { para isso }\end{array}$} \\
\hline \multicolumn{6}{|l|}{$\begin{array}{l}\text { 13. Ter impulsos que não se podem } \\
\text { controlar }\end{array}$} \\
\hline \multicolumn{6}{|l|}{$\begin{array}{l}\text { 14. Sentir-se sozinha mesmo } \\
\text { quando está com mais pessoas }\end{array}$} \\
\hline \multicolumn{6}{|l|}{$\begin{array}{l}\text { 15. Dificuldades em fazer qualquer } \\
\text { trabalho }\end{array}$} \\
\hline \multicolumn{6}{|l|}{ 16. Sentir-se sozinho } \\
\hline \multicolumn{6}{|l|}{ 17. Sentir-se triste } \\
\hline \multicolumn{6}{|l|}{ 18. Não ter interesse por nada } \\
\hline \multicolumn{6}{|l|}{ 19. Sentir-se atemorizado } \\
\hline \multicolumn{6}{|l|}{$\begin{array}{l}\text { 20. Sentir-se facilmente ofendido } \\
\text { nos seus sentimentos }\end{array}$} \\
\hline \multicolumn{6}{|l|}{$\begin{array}{l}\text { 21. Sentir que as outras pessoas } \\
\text { não são suas amigas ou não gostam } \\
\text { de si }\end{array}$} \\
\hline \multicolumn{6}{|l|}{ 22. Sentir-se inferior aos outros } \\
\hline \multicolumn{6}{|l|}{$\begin{array}{l}\text { 23. Vontade de vomitar ou mal do } \\
\text { estômago }\end{array}$} \\
\hline \multicolumn{6}{|l|}{$\begin{array}{l}\text { 24. Impressão de que os outros o } \\
\text { costumam observar ou falar de si }\end{array}$} \\
\hline \multicolumn{6}{|l|}{ 25. Dificuldade em adormecer } \\
\hline Em que medida foi incomodado & & & & & \\
\hline
\end{tabular}




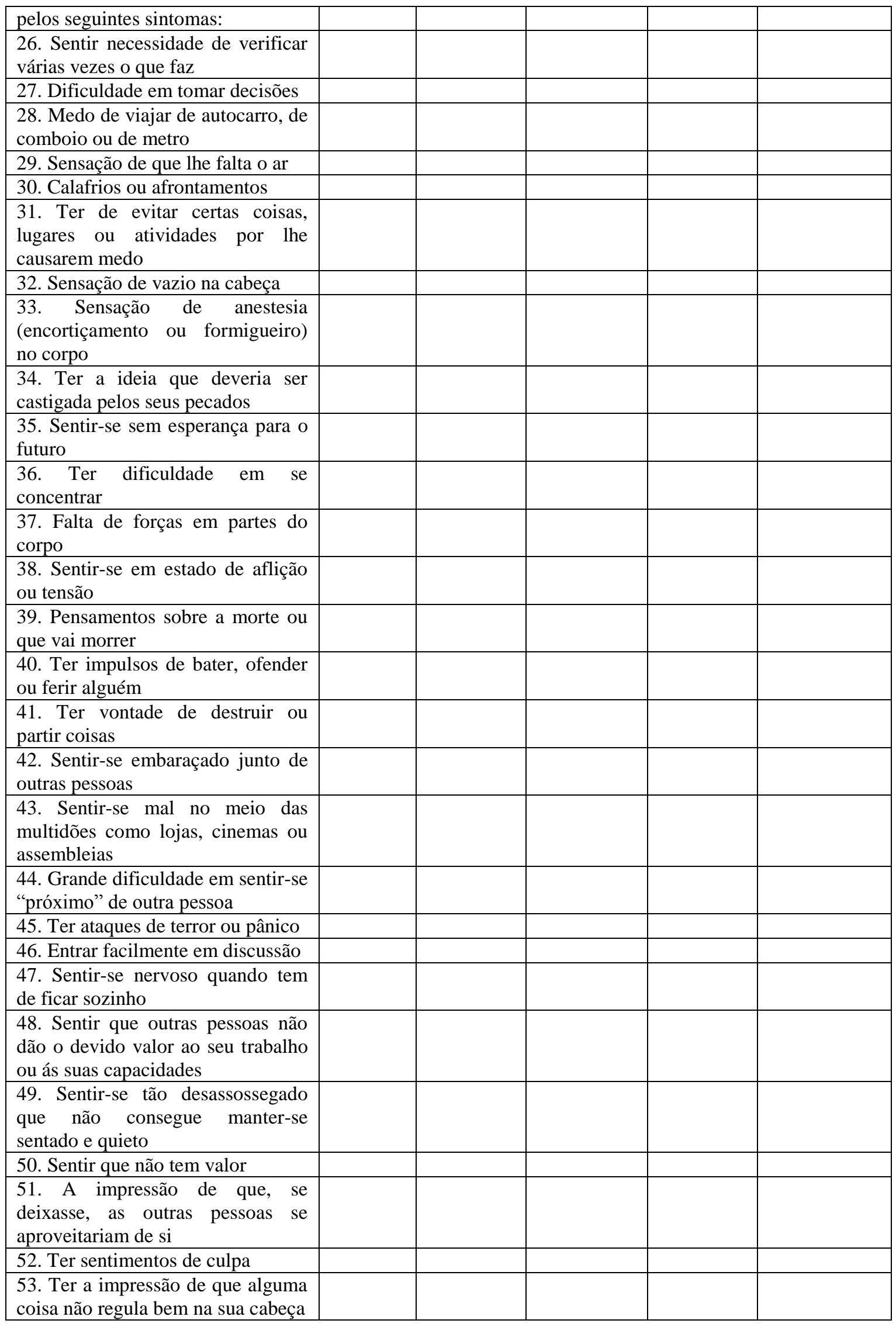


